
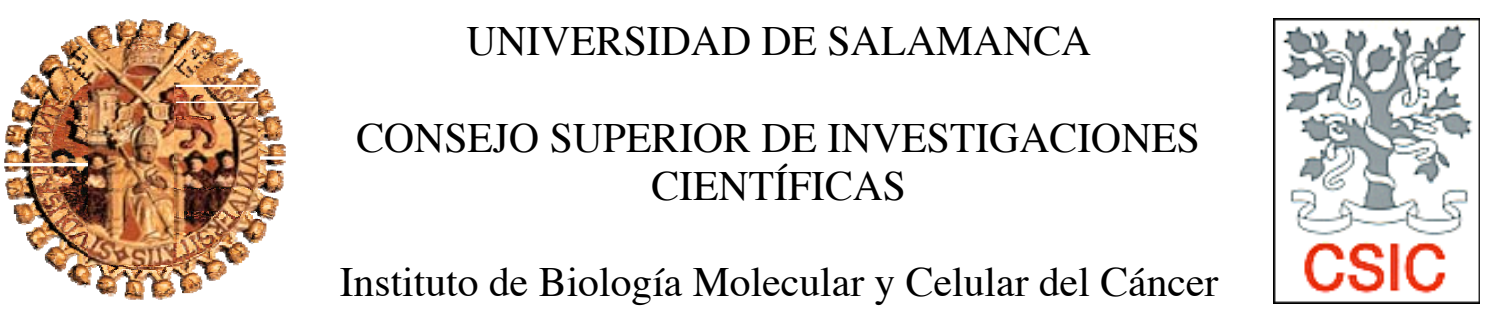

\title{
FUNCIÓN DEL GEN SNAI3 (SMUC) EN LA TRANSICIÓN EPITELIO MESENQUIMAL Y EN CÁNCER
}

\section{KATJA GUTSCHE}

Salamanca 2009 

D. ISIDRO SÁNCHEZ GARCÍA, INVESTIGADOR CIENTÍFICO DEL CONSEJO SUPERIOR DE INVESTIGACIONES CIENTÍFICAS (C.S.I.C.) EN EL INSTITUTO DE BIOLOGÍA MOLECULAR Y CELULAR DEL CÁNCER (IBMCC), CENTRO MIXTO DEL C.S.I.C. Y DE LA UNIVERSIDAD DE SALAMANCA .

\section{CERTIFICA:}

Que el trabajo titulado “Función del gen Snai3 (Smuc) en la transición epitelio mesenquimal y en cáncer" que presenta la doctoranda Dña. Katja Gutsche, ha sido realizado bajo su dirección en el Instituto de Biología Molecular y Celular del Cáncer, y reúne, a su juicio, originalidad y contenidos suficientes para que sea presentado ante el tribunal correspondiente y optar al Título de Doctor por la Universidad de Salamanca.

Y para que así conste, y a los efectos oportunos, expide el presente certificado en Salamanca, a 27 de Abril de dos mil nueve.

Dr. Isidro Sánchez García 


\section{ROGELIO GONZÁlEz SARMIENTO, CATEDRÁtiCo DEL DEPARTAMENTO DE MEDICINA DE LA UNIVERSIDAD DE SALAMANCA}

CERTIFICA:

Que ha sido el tutor del trabajo titulado "Función del gen Snai3 (Smuc) en la transición epitelio mesenquimal y en cáncer" presentado por la doctoranda Dña. Katja Gutsche, y que reúne, a su juicio, originalidad y contenidos suficientes para ser presentado ante el correspondiente tribunal y optar al Título de Doctor por la Universidad de Salamanca.

Y para que así conste, y a los efectos oportunos, expide el presente certificado en Salamanca, a 27 de Abril de dos mil nueve.

Prof. Rogelio González Sarmiento 
Durante mi período predoctoral he disfrutado de una beca asociado a un proyecto de investigación financiado por la Fundación de Investigación del Cáncer (Ref. G03/179), de una beca predoctoral del Consejo Superior de Investigaciones Científicas Programa I3P (Ref. I3P-B.O.E.15/07/2004) y de un contrato asociado a un proyecto de investigación financiado por la Universidad de Salamanca (Ref. LEI2 463A.C.07).

La investigación en nuestro grupo está financiado parcialmente por FEDER y por MICINN (SAF2006-03726), Junta de Castilla y León (CSI13A08), FIS (PI050087), proyecto CDTEAM (CENIT-Ingenio 2010), MEC OncoBIO Consolider-Ingenio 2010 (Ref. CSD2007-0017) y financiado como grupo de excelencia (Group of Excellence Grant) (GR15) por la Junta de Castilla y León. 
La ciencia se compone de errores, que a su vez, son los pasos hacia la verdad.

Die Wissenschaft besteht nur aus Irrtümern. Aber diese muss man begehen. Es sind die Schritte zur Wahrheit.

Jules (Julio) Verne 
Parece que fue ayer el día en que vine a Salamanca, solamente pudiendo decir "Hola", para empezar de trabajar en el Centro del Cáncer. Sin embargo no fue ayer, sino que fue allá por Febrero de 2004. Hoy, más de cinco años después, hay mucha gente a la que debo agradecer el resultado de todo este trabajo y espero no olvidarme a nadie.

Primero a Isidro por darme la posibilidad de realizar la tesis en su laboratorio, por integrarme en su grupo y por su apoyo.

Al Catedrático Rogelio González Sarmiento, tutor de este trabajo, y al Prof. Rafael Jiménez, por el permanente e incondicional apoyo que constantemente ofrecen a nuestro grupo.

A César y Jesús por su ayuda y apoyo cuando lo he necesitado.

Al equipo del Servicio de Experimentación Animal de la Universidad de Salamanca (Luis, Juan, Narci, Josito, Emilio, Carmen y Pedro), por su ayuda en el mantenimiento y cuidado de los ratones.

A la Dra. Teresa Flores Corral, por su inestimable ayuda en la preparación e interpretación de las muestras de anatomía patológica de los tumores.

A Ángel, por su ayuda en el análisis de las imágenes de microscopía.

Al servicio de Citometría de la Universidad de Salamanca dirigido por el Dr. Alberto Orfao, a Mari Luz por su colaboración en los análisis de inmunofenotipo de los ratones, y a Martín por su ayuda en el calibrado para el análisis de apoptosis y de ciclo celular mediante citometría de flujo.

A todos aquéllos cuyo trabajo hace posible que todo funcione. Al personal de administración, informática, mantenimiento, cocina, biblioteca y portería de ambos centros, que siempre han estado a nuestra disposición.

Al Dr. Thomas Gridley, que amablemente nos cedió el ratón mutante para Snai2. 
Al Dr. Antonio García de Herreros, por su amabilidad al facilitarnos las construcciones del promotor de E-caderina.

Al Dr. Lubo Vassilev, que amablemente nos facilitó las nutlins para los estudios de activación de p53.

Al Dr. Dave Tuveson, por su amabilidad al dejarnos los vectores pBabePuro.

Al Dr. Scott Lowe, que amablemente nos facilitó el vector pWZL Hygro-E1A 12s.

A Juan Luis y Manu, que amablemente me ayudaron con las fotos del TUNEL.

A Iván y Fernando por irradiar los ratones.

Al toda la gente del laboratorio 13, que están, "el equipo actual", Carol, Isa, Inés, Esther, Ale, Fer, Bea y Dalia y que han estado Cami, María, Manu, Iris, Angie, Pedro, Laura, Teresa. Gracias por vuestra ayuda en todo lo que he necesitado, por la paciencia de explicarme y enseñarme el castellano (en gran medida he ampliado mi vocabulario más allá de "gracias" y "hola" gracias a vosotros), por ayudarme al principio en traducir todos mis documentos, y por crear un ambiente en el que se trabaja a gusto.

A Cami, María, Manu e Iris por ser más que sólo compañeros de laboratorio, amigos. Gracias por vuestra ayuda, ánimo y conversaciones, con las que he aprendido mucho de lo que necesitaba saber sobre la vida laboral y fuera del labo. ¿Qué haría yo sin vosotros y esas salidas por la noche tomando cañas y pinchos... uno, dos, tres o más?

Especialmente a Cami, con la que compartí tantos momentos durante todo este tiempo dentro y fuera del laboratorio y que finalmente me ayudó mucho con la tesis dándome ideas de expresiones y corrigiendo la gramática.

A mis excompañeras de piso Benchi e Ida por el buen tiempo que pasamos juntas en el piso, haciendo barbacoas en nuestra terraza tan grande, charlando de todas esas cosas de la vida y estar de marcha por la noche. Gracias también a Elisa y Regina.

A Cris, Manu, Adri, Alfonso, Inma, Fran, Trini y Pablo por todas esas cenas, las fiestas (de cumpleaños, las primeras fiestas de despedidas, las bodas correspondientes) y nuestros viajes juntos. Gracias por hacerme la vida fuera del labo tan amena. 
Al "clan Sánchez" por todas esas fiestas en La Maza ya sea por un cumple (como hay tantos), la construcción del horno, las matanzas y el herradero (cosas que no había visto de esta manera) o sólo por el buen tiempo.

Al todo el resto de la gente que ha vivido mi Tesis un poco más lejos:

A Gerald que fue el primero que me enseñó de qué va esto de la ciencia, por animarme hacer la tesis y por su ayuda anteriormente para encontrar este sitio.

A mis amigos, que siempre han tenido tiempo cuando he pasado por Berlín o Gera. Gracias por vuestras visitas, ¿Ya habeis venido todos, no?, las noches que hemos pasado horas y horas hablando por teléfono y por ser personas con las que sé que podré contar siempre:

A Franni y Silvia (o Elchi y Heidi) por vuestro ánimo y apoyo durante este tiempo, ya que nos entendemos haciendo "lo mismo”. ¡Qué bien me lo pasé y espero pasarme en el futuro en nuestras "reuniones científicas", los viajes de fines de semana por Europa!

A mis amigas de "toda la vida" Isa, Katja y Jule. Me alegro mucho de que todavía sigamos en contacto, y de que cada vez que nos vemos todo sigue como siempre.

A mi “equipo berlinés” Nadine, Annika, Melanie, Sara, Nina y Daniel.

A mi familia, mis padres y mi hermana por todo el ánimo, apoyo y cariño que me estáis dando siempre. Gracias por creer tanto en mí.

A Iván, por ser la persona que ha compartido el mayor tiempo a mi lado en los últimos tres años, por la paciencia que tiene y por animarme, apoyarme y hacerme sonreír cada día.

Salamanca, a 27 de Abril de 2009

Katja Gutsche 
1. Cáncer

1.1 Definición 23

1.2. La tumorogénesis y las alteraciones genéticas en el cáncer 24

1.3. Oncogenes, genes supresores de tumores y genes reparadores del DNA 25

2. p53, un gen supresor de tumores 26

2.1. p53 y daño en el DNA ___ 26

2.2. Estructura de p53 ___ 28

2.3. Activación y estabilización de p53 tras daño en el DNA ___ 29

2.4. Respuestas celulares tras daño en el DNA mediada por p53 _ 31

2.4.1. Parada del Ciclo Celular ___ 32

2.4.2. Reparación del daño________ 33

2.4.3. Apoptosis ____ 34

2.4.4. Senescencia __ 35

2.5. p53 y Cáncer ___ 35

3. La transición epitelio mesenquimal (EMT) __ 37

4. La familia Snail __ 39

4.1. Clasificación y evolución filogenética ___ 39

4.2. Estructura ___ 40

4.3. Regulación ____ 42

4.4. Snai1/Snai2 y la EMT _____ 43

4.5. Snai1/ Snai2 y supervivencia celular ___ 45

4.6. Snai1/Snai2 y Cáncer_____ 46

4.7. Snai3, otro miembro de la familia Snail____ 48

OBJETIVOS ________________ 39

HIPÓTESIS

RESULTADOS__ 47

1. Función de Snai3 en la transición epitelio mesenquimal (EMT) _ 61

1.1. Snai3 reprime el promotor de E-caderina ___ 61

1.2. La expresión de Snai3 en células MDCK no induce características mesenquimales 63

2. Función de Snai3 en la supervivencia celular ___ 69

2.1. La retirada de IL-3 induce la expresión de Snai3 ___ 70

3. Regulación de la expresión de Snai3 en respuesta al daño en el DNA _ 71

3.1. La expresión de Snai3 está regulada tras daño en el DNA ___ 71

3.2. La inhibición del proteasoma no aumenta la cantidad de proteína de Snai3 tras el daño en el DNA provocado por doxorrubicina___ 73

3.3. La expresión de Snai3 se regula de una manera dependiente de p53 tras daño en el DNA 75 
3.4. El promotor de Snai3 se induce tras daño en el DNA de una manera dependiente de p53

3.5. La activación de Snai3 está mediada específicamente por la vía de p53 ___ 79

3.6. Snai3 es una diana de p53 ___ 80

4. Estudios de sobre-expresión de Snai3__ 83

4.1. Snai3 se localiza en el núcleo____ 83

4.2. Participación de Snai3 en las respuestas celulares tras daño en el DNA ___ 84

4.2.1. Apoptosis __ 84

4.2.1.1. Expresión de Snai3 en células E1A-MEFs control y E1A-MEFs $\mathrm{p} 53^{-/}$

4.2.1.2. La sobre-expresión de Snai3 en MEFs control no induce apoptosis tras daño en el DNA

4.2.1.3. La sobre-expresión de Snai3 no induce apoptosis en MEFs p53 ${ }^{-1}$

4.2.1.4. Inducción de apoptosis en el timo de ratones que expresan Snai3 constitutivamente tras radiación- $\gamma$ ___ 90

4.2.1.4.1. Generación de ratones CombitTA-Snai3 ___ 90

4.2.1.4.2. Snai3 no induce apoptosis en ratones que sobre-expresan Snai3 ___________ 91

4.2.2. Ciclo celular __ 94

4.2.2.1. Las células MEFs control que sobre-expresan Snai3 proliferan menos y muestran un descenso en el porcentaje de células en fase $\mathrm{S}$

4.2.2.2. Las células MEFs $\mathrm{p} 53^{-/}$que sobre-expresan Snai3 no muestran un comportamiento

diferente ni en la proliferación, ni en el ciclo celular ___ 98

5. El papel de Snai3 en la tumorogénesis__ 101

5.1. Snai3 está implicada en el desarrollo de cáncer en ratones ___ 102

5.2. Snai3 acelera el desarrollo de tumores en ratones $\mathrm{p53}^{-/}$

6. Regulación entre los miembros de la familia Snail ___ 112

6.1. Regulación transcripcional entre los miembros Snai3 y Snai2 de la familia Snail _ 112

6.2. La expresión de Snai3 aumenta en ausencia de Snai2___ 114

6.3. La expresión exógena de Snai 2 modifica la expresión de Snai3 en distintos tipos de MEFs

6.4. Snai2 reprime el promotor de Snai3___ 119

6.5. Snai3 es una diana directa de Snai2 ___ 120

DISCUSIÓN __ 111

1. Papel de Snai3, un miembro de la familia Snail, en la transición epitelio mesenquimal (EMT)

2. Papel de Snai3, un miembro de la familia Snail, en la respuesta tras daño en el DNA

3. Papel de Snai3, un miembro de la familia Snail, en la génesis del cáncer

1.1. Obtención de la secuencia codificante de Snai3

1.1.1. Tratamiento del RNA con DNasaI

1.1.2. Obtención de cDNA a partir de RNA tratado con DNasaI

1.1.3. PCR a partir del cDNA

1.1.4. Ligación del cDNA de Snai3 en el vector pBluescript KS+ 
1.1.5. Preparación de DH5 $\alpha$ competente y transformación plasmídica

1.1.6. Selección de las colonias con inserto y secuenciación del cDNA

1.2. Generación del vector $p Q C X I P-S n a i 3$

1.2.1. Obtención de la secuencia codificante de Snai3

1.2.2. Preparación del vector $\mathrm{pQCXIP}$

1.2.3. Ligación del cDNA de Snai3 en el vector pQCXIP

1.3. Generación del vector CombitTA-Snai3

1.3.1. Obtención de la secuencia codificante de Snai3

1.3.2. Preparación del vector CombitTA

1.3.3. Ligación del cDNA de Snai3 en el vector CombitTA

1.4. Generación del vector pEGFP-C1-Snai3

1.4.1. Obtención de la secuencia codificante de Snai3

1.4.2. Preparación del vector $\mathrm{pEGFP-C1}$

1.4.3. Ligación del cDNA en el vector pEGFP-C1

1.5. Generación del vector pGL3-mSnai3 (2785bp)

1.5.1. Obtención de la secuencia del promotor de Snai3

1.5.2. Preparación del vector pGL3-basic

1.5.3. Ligación del promotor de Snai3 en el vector 146

1.6. Generación del vector pBabePuro-mSnai2

1.6.1. Obtención de la secuencia codificante de Snai2

1.6.2. Preparación del vector $\mathrm{pBabePuro}$

1.6.3. Ligación del cDNA en el vector pBabePuro

2. Generación de ratones modificados genéticamente

2.1.Generación de ratones CombitTA-Snai3

2.2. Generación de ratones CombitTA-Snai3; 53 $^{-/-}$ 150

2.3. Generación de ratones Snai2 ${ }^{-/-}$ 151

2.4. Generación de ratones $\mathrm{p} 53^{-/-} ; \mathrm{Snai}^{-/-}$ 151

3. Genotipar los ratónes y los embriones 151

3.1. Mediante Southern blot 151

3.1.1. Extracción de DNA a partir de las colas y del hígado de los embriones

3.1.2. Digestión de las muestras de DNA 151

3.1.3. Electroforesis del DNA en geles de agarosa 152

3.1.4. Transferencia del DNA a membranas de nylon

152

3.1.5. Hibridación de las membranas con una sonda marcada con $\left[\alpha-{ }^{32} \mathrm{P}\right] \mathrm{dCTP}$

3.2. mediante PCR

4. Exposición de ratones a radiación- $\gamma$

5. Cultivos celulares__ 155

5.1. Tipos celulares utilizados ___ 155

5.2. Obtención de Fibroblastos embrionarios de ratón (MEFs) __ 155

5.3. Tratamientos de los MEFs para estudios de expresión génica y/o proteíca___ 157

5.3.1. Preparación de los MEFs

5.3.2. Tratamiento con doxorrubicina____ 157

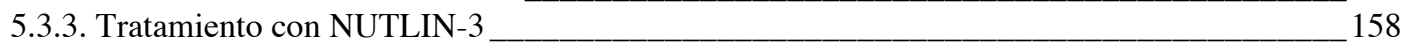

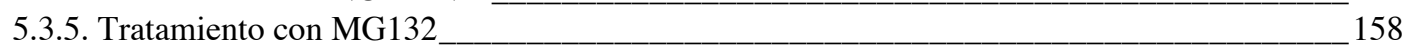

5.4. Transducción retroviral ___ 158

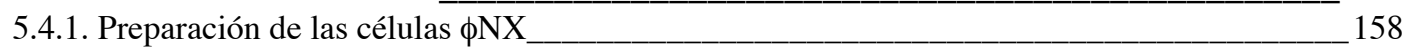

5.4.2. Preparación del DNA _________________________ 159 
5.4.3. Transfección de las $\phi \mathrm{NX}$

5.5. Transfección de lineas celulares mediado por fosfato cálcico

5.5. Generación de clones estables de MDCK que expresan Snai3 utilizando FuGENE 6

5.5.1. Preparación de las células

5.5.2. Preparación del DNA

5.5.3. Transfección de las células

5.6. Ensayos de proliferación 163

6. Análisis de la expresión génica 163

6.1. mediante Northern blot 163

6.1.1. Extracción de RNA total a partir de los MEFs ___ 163

6.1.2. Separación del RNA en un gel de agarosa ______________ 164

6.1.3. Transferencia del RNA a membranas de nylon________ 164

6.1.4. Hibridación de la membrana______ 164

6.2. mediante PCR _ 165

6.2.1. RT-PCR para Snai3 ___ 165

6.2.1.1. RT-PCR qualitativa____________ 165

6.2.1.2. RT-PCR semicuantitativa _______________________________________________

7. Análisis de la expresión proteica___ 166

7.1. Obtención del extracto proteico total____ 166

7.2. Electroforesis en geles SDS-PAGE ___ 167

7.3. Transferencia a membrana PVDF y marcaje con anticuerpos___ 167

8. Análisis de la interacción proteína-cromatina mediante la inmunoprecipitación de cromatina (ChIP)_ 169

9. Ensayo Luciferasa ___ 172

10. Estudios de Apoptosis __ 173

10.1. mediante FACS ___ 173

10.2. mediante marcaje in situ del DNA fragmentado o técnica de TUNEL (TdTmediated dUTP Nick-End Labeling)___ 174

11. Estudio del ciclo celular _ 175

12. Localización subcelular de la proteína de fusión GFP-Snai3 mediante microscopía confocal. Inmunofluoresecencia para GFP 176

13. Estudios anatomo-patológicos___ 177

13.1. Extracción de órganos ___ 177

13.2. Inclusión de los órganos en parafina ___ 177

13.3. Desparafinado y re-hidratación de las muestras ____ 178

13.4. Tinción con hematoxilina-eosina ___ 178

13.5. Definición anatomo-patológica y fotografiado de las muestras ___ 179

14. Curvas de superviviencia de ratones__ 179 
ABREVIATURAS 
INTRODUCCIÓN 


\section{Cáncer}

\subsection{Definición}

Cáncer es el término común con el que se definen enfermedades distintas, existiendo muchos tipos diferentes de cáncer, tantos como tipos celulares hay en el cuerpo humano.

En condiciones fisiológicas, el balance entre proliferación y muerte celular en un tejido está perfectamente controlado, de modo que se permite el correcto recambio celular. Este equilibrio puede verse alterado por necesidades del propio tejido, pero siempre bajo un estricto control, como ocurre, por ejemplo en la cicatrización de las heridas. Así mismo, la diferenciación celular también está controlada de forma rigurosa y, en general, acoplada de forma inversa al grado de proliferación. En el cáncer se altera toda esta regulación, produciéndose una proliferación continua, que suele ir acompañada de pérdida, en grado diverso, de la capacidad de diferenciación y de una resistencia variable a la muerte celular programada (Cobaleda et al., 1998; SanchezGarcia, 1997).

El término cáncer es usado para identificar una afección clínica de carácter maligno, aunque también se usan los términos tumor maligno y neoplasia maligna.

Los tumores son masas celulares formadas por clones de células que han perdido los controles que regulan su multiplicación celular, y se dividen según su composición en tumores benignos y malignos. Los tumores benignos están formados por células que son parecidas a las normales y pueden funcionar como éstas, y además suelen estar muy localizados allí donde se originan. Los tumores malignos, en cambio, se componen de células menos diferenciadas y tienen propiedades invasivas y de propagación: es decir, invaden tejidos adyacentes y establecen áreas de proliferación lejos de su lugar de origen. Los tumores malignos se clasifican según la procedencia de la célula originaria transformada.

Principalmente los tumores malignos se pueden clasificar en dos tipos según su origen: tumores epiteliales y mesenquimales. Los tumores epiteliales, tanto de origen ectodérmico como endodérmico, son los carcinomas. Son cánceres que surgen en láminas de epitelios que recubren superficies. Por otro lado, se encuentran los sarcomas, las leucemias y los linfomas, que son tumores de estirpe mesenquimal (Darnell et al., 1990). Los sarcomas son tumores sólidos, y las leucemias y los linfomas se incluyen dentro de los tumores hematopoyéticos. 


\subsection{La tumorogénesis y las alteraciones genéticas en el cáncer}

El proceso canceroso, llamado tumorogénesis, es un proceso que incluye múltiples etapas durante las cuales se acumulan varias alteraciones genéticas y epigéneticas en el DNA para producir un fenotipo maligno completo. Es un proceso clonal que se origina en una primera y única célula que, por una o varias mutaciones iniciales, escapa a los controles normales de proliferación y diferenciación, lo que le confiere una ventaja en su crecimiento sobre las demás células (Figura 1). Los cambios genéticos incluyen mutaciones o deleciones puntuales, amplificaciones y translocaciones cromosómicas. Estas últimas suponen, con gran frecuencia, la creación de un gen de fusión y son características de tumores de origen mesenquimal, tanto de leucemias como de tumores sólidos (Cobaleda et al., 1998; Sanchez-Garcia, 1997). Sin embargo, las alteraciones epigenéticas incluyen tres tipos diferentes de cambios: metilación del DNA, modificaciones de histonas y cambios en el imprinting genético (Feinberg and Tycko, 2004). La mayoría de las células cancerosas poseen al menos seis propiedades comunes que son esenciales para la transformación de una célula normal hacia un fenotipo maligno (Hanahan and Weinberg, 2000). Estas capacidades adquiridas son: la independencia de señales de proliferación, la insensibilidad a señales de inhibición de la proliferación, el escape de la muerte celular programada (apoptosis), el potencial de replicación ilimitada, la angiogénesis continua y la invasión de tejidos locales y metástasis (Hanahan and Weinberg, 2000).

(1)

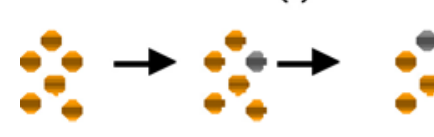

INICIO PROMOCIÓN
(2)

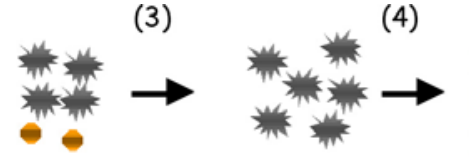

PROGRESIÓN

Figura 1. Etapas en la progresión tumoral. La tumorogénesis en el hombre clásicamente se considera que consta de varios pasos en los cuales se acumulan lesiones génicas que conducen a la progresiva transformación de células normales en células malignas. (1); las células aún tienen fenotipo normal, (2); expansión del clon premaligno, (3); crecimiento clínico, (4); expansión del clon maligno y cambios genéticos adicionales que conducen a la diseminación. 


\subsection{Oncogenes, genes supresores de tumores y genes reparadores del DNA}

Como ya hemos comentado, el cáncer se origina como consecuencia de la acumulación de alteraciones genéticas y epigenéticas en el DNA.

Los cambios genéticos que conducen a un fenotipo maligno, implican la activación de oncogenes y/o la inactivación de genes supresores de tumores y de genes reparadores del DNA, lo que origina un desequilibrio en la señalización de proliferación (Figura 2).

(2)

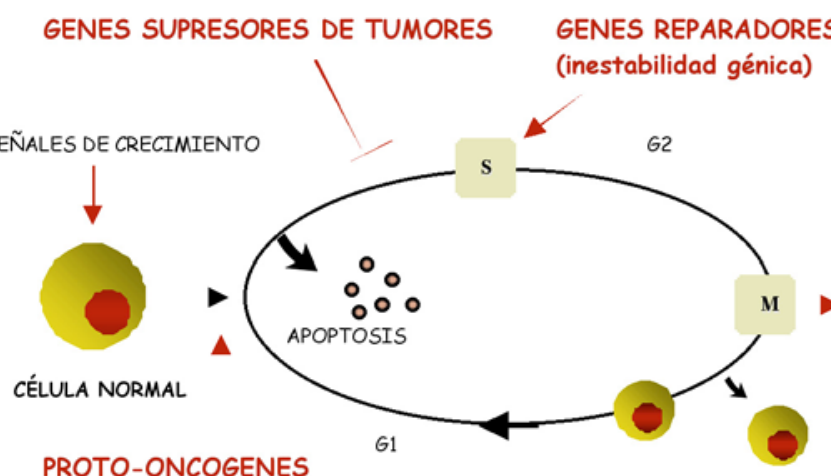

(4)

METÁSTASIS

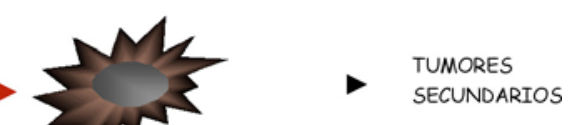

CÉLULA TUMORAL

(1)

Figura 2. Vías moleculares en el desarrollo del cáncer. Pueden distinguirse cuatro grandes categorías funcionales de genes cuya alteración participa en el desarrollo del cáncer: (1) y (2); vías que regulan la proliferación y controlan la progresión a lo largo del ciclo celular y la apoptosis, (3); genes reparadores de DNA, cuya alteración genera inestabilidad cromosómica, y (4); genes asociados con la diseminación local y a distancia.

Los proto-oncogenes, en condiciones normales, estimulan la proliferación celular, de manera que las células con oncogenes mutados siguen proliferando aun sin recibir señales de proliferación (Vogelstein et al., 2000). Los oncogenes activados actúan generalmente de forma dominante, y entre ellos se encuentran factores de crecimiento, receptores de factores de crecimiento, transductores de señales, proteínkinasas y activadores transcripcionales.

Los genes supresores de tumores controlan el número de células inhibiendo la progresión del ciclo celular o favoreciendo la muerte celular (Vogelstein et al., 2000). Al contrario que los oncogenes, los genes supresores de tumores actúan de forma recesiva. 
Los estudios funcionales realizados con genes supresores humanos indican que la pérdida de función de éstos es el evento génico asociado con la progresión hacia un estado maligno (Tainsky et al., 1995).

Los genes reparadores del DNA intervienen en la corrección de roturas en el DNA de doble cadena mediante mecanismos de recombinación homóloga o de unión no homóloga, y así controlan el ratio de mutaciones de todos los genes. Si estos genes reparadores del DNA están mutados, las células adquieren mutaciones en los oncogenes y/o en los genes supresores de tumores de forma acelerada, favoreciendo así el inicio y la progresión de los tumores (Vogelstein et al., 2000).

\section{2. p53, un gen supresor de tumores}

Como hemos explicado anteriormente, para que se manifieste el proceso canceroso se tienen que acumular diferentes mutaciones en genes específicos, como son los oncogenes y los genes supresores de tumores. Uno de los genes más ampliamente estudiado es $p 53$.

p53 es una proteína muy importante para la conservación de la integridad de la célula, y por ello, muchas veces se le denomina "portero celular" o "guardián del genoma" (Efeyan and Serrano, 2007; Lane, 1992; Levine, 1997). Podría decirse que el papel que desarrolla como tal es el de mantener la estabilidad genómica global, pues células sin p53 presentan con una gran frecuencia aberraciones cromosómicas de varios tipos. Actualmente no hay duda de la importante contribución que p53 realiza para mantener la integridad genómica e inhibir la conversión tumorogénica de las células (Midgley et al., 1992).

\section{1.p53 y daño en el DNA}

p53 necesita estar activada para funcionar como proteína supresora de tumores, porque en condiciones fisiológicas el nivel proteico de p53 se mantiene bajo, es decir, que la vía de acción de p53 está apagada. Esta vía de p53 se induce tras diferentes tipos de estrés en la célula, que incluyen la activación de oncogenes, la hipoxia, el estrés oxidativo, la pérdida de señales de soporte o de superviviencia (Vousden and Lu, 2002), o el daño en el DNA, que posiblemente, es el evento más estudiado para la inducción de p53 (Carr, 2000).

Los organismos al sufrir daño en su DNA responden activando una compleja vía de respuesta al mismo. Esta vía está formada por diferentes proteínas que son capaces 
de iniciar los programas de una respuesta celular adecuada como son el arresto reversible del ciclo celular o respuestas irreversibles como son la apoptosis o la senescencia (May and May, 1999; Vousden and Lu, 2002) (Figura 3). Este complejo circuito es esencial para el mantenimiento y la regulación de los niveles intracelulares y la activación de p53, que una vez activado se acumula en el núcleo donde regula la transcripción de diferentes genes de diana, a través de los cuales va a iniciar uno de los procesos celulares en respuesta al daño en el DNA.

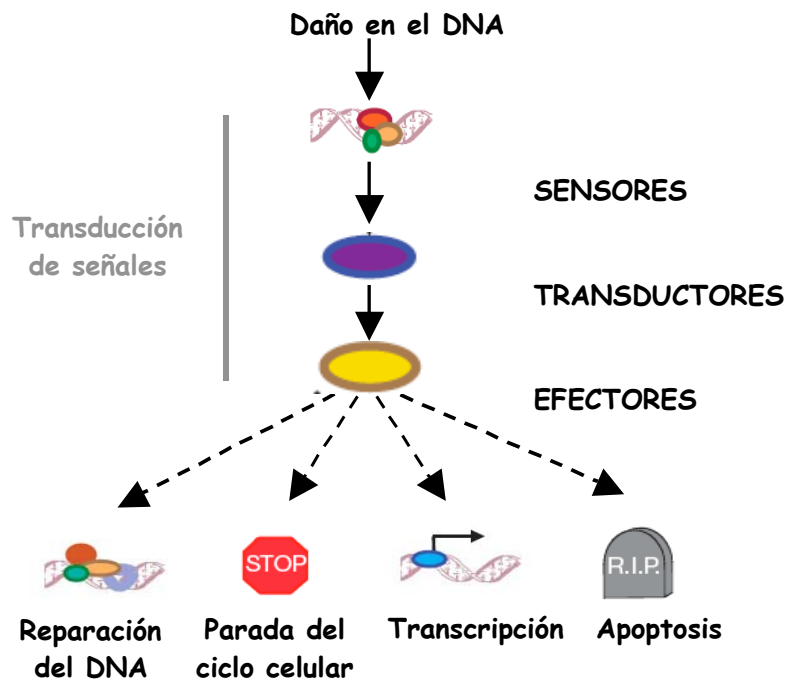

Figura 3: Esquema general de la vía de transducción de señales para iniciar una respuesta celular tras daño en el DNA. Todas las vías que se pueden activar tras daño en el DNA y que interactúan entre ellas están representadas como una vía lineal que consta de sensores, transductores y efectores, que son las moléculas que traducen las señales del daño para dar lugar a una respuesta. Figura modificada de (Zhou and Elledge, 2000).

Tras daño en el DNA, ya sea provocado por radiación gamma o ultravioleta (UV), por alquilación de bases, por depurinación del DNA, por ataque de radicales reactivos de oxígeno o por agentes de quimioterapéuticos, p53 está sujeto a una serie de modificaciones post-traduccionales dependientes del contexto. Estas modificaciones incluyen cambios en la estructura de p53 y causan su estabilización y su activación transcripcional (Bode and Dong, 2004; Yang et al., 2006). Así, una sola rotura en la doble cadena de DNA sería suficiente para provocar un rápido aumento en los niveles de p53 en la célula, y la activación de p53 como factor de transcripción (Huang et al., 1996; Wahl et al., 1997). El incremento en los niveles de p53 es proporcional a la extensión del daño en el DNA, pero va a ser diferente para distintos tipos de daño (Levine, 1997).

La importancia de este circuito se pone de manifesto por el hecho de que alguno de los factores que lo componen está ausente en todos los tumores (Jin and Levine, 2001). 


\subsection{Estructura de p53}

El gen humano p53 (TP53) codifica para una proteína de 393 aminoácidos, y está conservado durante la evolución. El gen contiene 11 exones de los cuales el primero es no-codificante. El análisis de la secuencia de aminoácidos puse de manifiesto la existencia de 4 dominios principales altamente conservados (May and May, 1999; Soussi et al., 1990; Soussi and May, 1996): el dominio de transactivación aminoterminal (Nt), el dominio central de unión a secuencias específicas de DNA (DBD), el dominio de oligomerización (TD), que contiene también una señal de exportación nuclear (Stommel et al., 1999), y el dominio regulador carboxi-terminal (Ct) (Romer et al., 2006) (Figura 4).

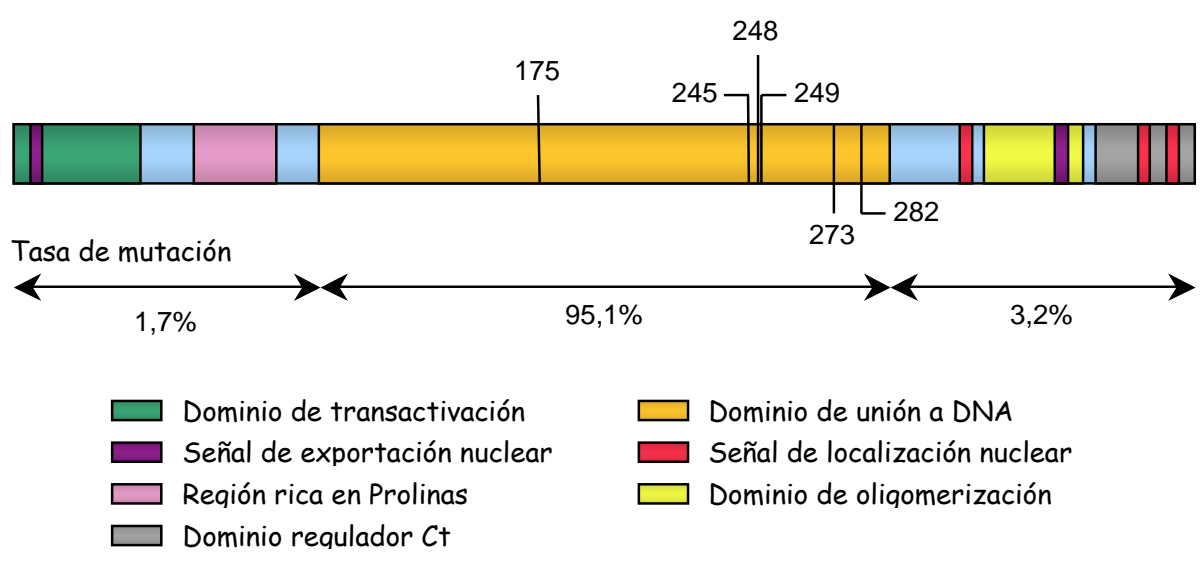

Figura 4: Estructura y dominios funcionales de la proteína p53. Los diferentes dominios están representados en diferentes colores como también las señales de exportación nuclear y las señales de localización nuclear.

El dominio amino-terminal de p53 contiene dos partes, la región de activación transcripcional y otra región rica en prolinas (Romer et al., 2006). Este dominio contiene una señal fuerte de la activación transcripcional (Vogelstein and Kinzler, 1994) y participa en la activación transcripcional de numerosos genes dianas ( $\mathrm{Lu}$ and Levine, 1995), pero ahí también se van a unir proteínas que van a regular negativamente a p53 (como MDM2) (Levine, 1997; Lin et al., 1994). La región rica en prolinas reconoce proteínas que contienen el dominio $\mathrm{SH} 3$ y tiene una función importante, tanto en el proceso de apoptosis (Sakamuro et al., 1997; Walker and Levine, 1996; Zhu et al., 1999) como en la represión de sus genes dianas mediada por p53 (Venot et al., 1998). De todo esto se deduce que la inhibición funcional del dominio de activación de p53 es clave en el proceso de tumorogénesis. 
El dominio de unión al DNA es un dominio resistente a las proteasas, y es la región de p53 donde se encuentran la mayoría de las mutaciones relacionadas con el cáncer (Figura 4). Este dominio reconoce la secuencia consenso de 10bp 5 $(\mathrm{PuPuPuC}(\mathrm{A} / \mathrm{T})(\mathrm{A} / \mathrm{T}) \mathrm{GPyPyPy})_{2}-3 `$ en la región reguladora del promotor del gen diana (el-Deiry et al., 1992). La función de transactivación de p53 regulada por el estrés celular está mediado por este dominio (Gomez-Lazaro et al., 2004).

El dominio de oligomerización asegura el ensamblaje de p53 en tetrámeros activos (Hupp et al., 1992; Wang et al., 1994). La oligomerización de p53 es necesaria e importante para la transactivación y para la supresión del crecimiento celular dependiente de p53 (Pietenpol et al., 1994).

Finalmente, el dominio regulador carboxi-terminal $(C t)$, como su nombre indica, es muy importante para la regulación de la proteína (Ahn and Prives, 2001). Este dominio está conectado con el dominio de la oligomerización por una región de basic linker en la que están localizadas las señales de localización nuclear (NLS) (Shaulsky et al., 1990).

\subsection{Activación y estabilización de p53 tras daño en el DNA}

Como ya hemos comentado antes, el daño en el DNA induce una vía de transducción de señales en la cual p53 juega un papel muy importante y esto implica la activación y estabilización de p53 para aumentar la cantidad de proteína activa y para que actúe como factor de transcripción.

p53 sería activada por diferentes proteínas como son las quinasas ATM, ATR, Chk1 y Chk2, que son las que reciben la señal del daño en el DNA (Figura 5). Según el tipo de daño actúan unas u otras, pero todas fosforilan p53 en el extremo $\mathrm{N}$-terminal (Appella and Anderson, 2001; Shieh et al., 2000). Las quinasas ATM y Chk2 son sensores de roturas en la doble cadena de DNA e inducidas por irradiación gamma. ATR y Chk1, por otro lado, están inducidas por irradiación UV, por agentes quimioterapéuticos y por inhibidores de proteínas quinasas (Vogelstein et al., 2000).

Este proceso de fosforilación tiene como consecuencia la inhibición de la degradación de p53 y así su estabilización a una concentración alta (Vogelstein et al., 2000). La degradación de p53 y así su regulación negativa procede mediante un proceso llamado proteolisis dependiente de ubiquitina. En este proceso MDM2 (HDM2 en humanos) juega el papel más relevante, añadiendo cadenas de ubiquitina a p53. MDM2 
es una ligasa E3 que se une a p53 y la inactiva, al promover su exportación al citoplasma y posterior degradación en el proteasoma, y al interferir con el reclutamiento de los componentes de la maquinaria de transcripción basal (Gottifredi and Prives, 2001; Haupt et al., 1997; Kubbutat et al., 1997; Lambert et al., 1998; Prives and Hall, 1999). Numerosos estudios han demostrado que MDM2 se une al dominio aminoterminal de p53, que es la región que contiene varios sitios de fosforilación de p53, y de esta manera inhibe la transcripción dependiente de p53 (Chen et al., 1993; Oliner et al., 1993). Cuando existe daño en el DNA, p53 es fosforilada, como ya hemos comentado, lo que induce un cambio conformacional que hace que MDM2 es incapaz de unirse a p53, resultando en la supresión del efecto inhibidor de MDM2 sobre p53 (Shieh et al., 1997). MDM2 también contribuye a su propia degradación porque es capaz de ubiquitinarse a sí mismo. A su vez, el promotor de MDM2 tiene un sitio de unión de p53 y es así transactivado por p53 (Barak et al., 1993; Perry et al., 1993; Zauberman et al., 1993). Así, niveles altos de MDM2, inducidos por el aumento de la actividad de p53, generan un circuito auto-regulado que lleva a una reducción rápida de la proteína p53, y eso permite a p53 actuar en un tiempo corto antes de que su nivel baje otra vez a niveles normales (Haupt et al., 1997; Kubbutat et al., 1997). En ausencia de proteína MDM2 funcional, p53 se desregula y su exceso de actividad conduce a la letalidad embrionaria (Lozano and Liu, 1998). Una excesiva expresión de MDM2 podría generar una inhibición constitutiva de p53, favoreciendo el desarrollo de tumores.

Este circuito entre MDM2 y p53, que hemos explicado previamente, puede interconectarse con otro circuito formado por p19 ${ }^{\mathrm{ARF}}$ y E2F-1, que funciona de forma muy similar al anterior. Esta conexión está organizada de tal manera que p19 $9^{\mathrm{ARF}}$ interacciona con MDM2, inhibiendo la ubiquitinación y la degradación de p53 mediada por MDM2, y que p53 reprime la transcripción del gen p19ARF (Figura 5) (Jin and Levine, 2001).

Además hay otras dos ligasas de ubiquitinación, COP1 y Pirh-1, que forman, cada una por su parte, un circuito auto-regulado favoreciendo la degradación de p53 (Dornan et al., 2004; Leng et al., 2003), y también hay varias proteínas más que juegan un papel en la interacción entre MDM2 y p53 (Cummins and Vogelstein, 2004; Li et al., 2004; Sui et al., 2004). De la misma manera, la fosforilación y la ubiquitinación no son los únicos procesos de las modificaciones post-traduccionales de p53, sino que también están implicadas la sumoilación, la nedilación y la acetilación (Harris and Levine, 2005; Watson and Irwin, 2006). 


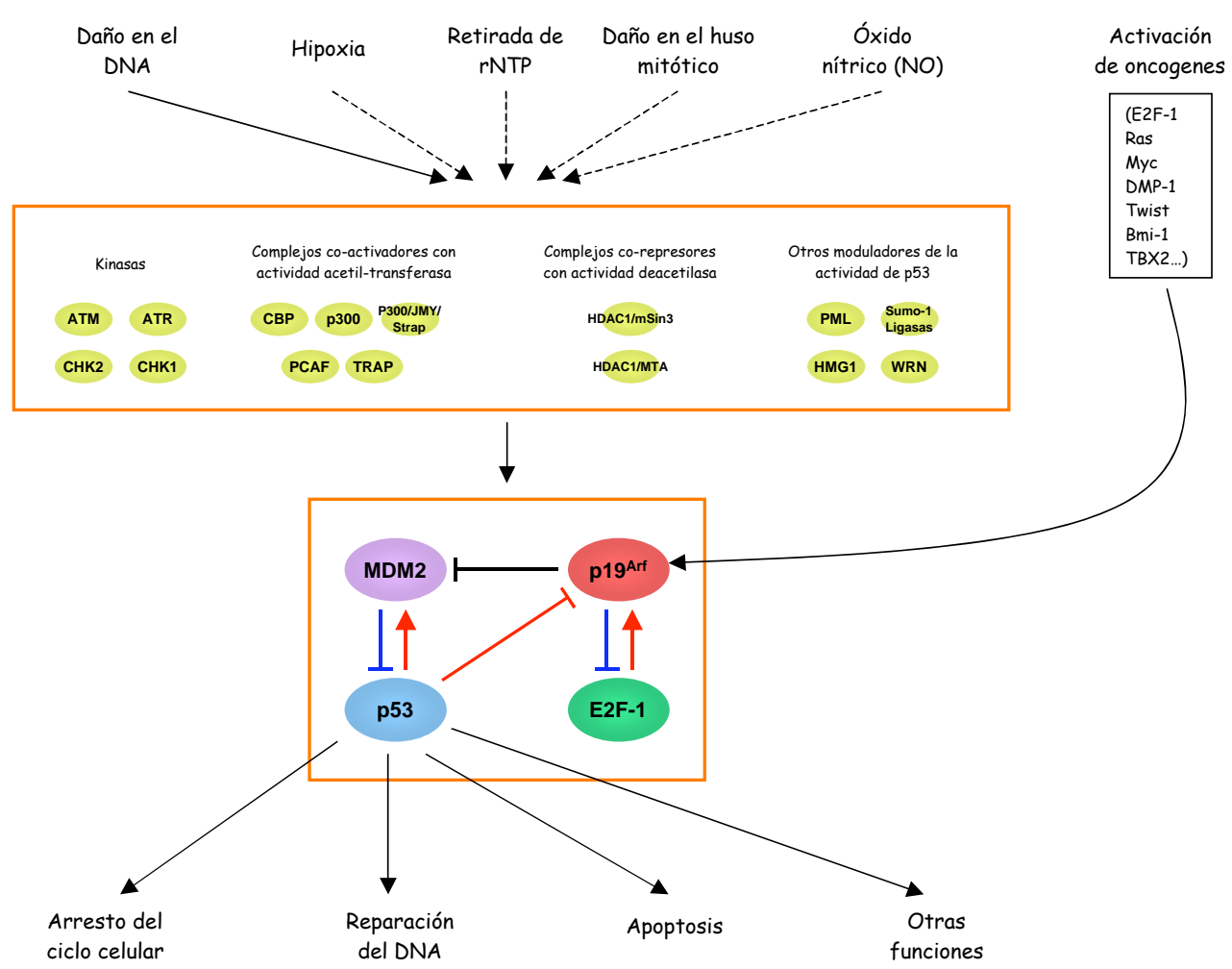

Figura 5: La vía celular de p53. Diferentes tipos de estrés celular activan la vía de p53, que a su vez está estrechamente regulado en las células. Cuando p53 se activa, recluta complejos coactivadores o co-represores de la transcripción, pero la cooperación entre p53 y otros factores de transcripción va a ser la que determine la elección final de la respuesta. Figura modificada de (Jin and Levine, 2001).

Los modelos in vivo, sin embargo, han sugerido que las modificaciones posttraduccionales sólo ejercen una pequeña modulación de la regulación de p53 (Toledo and Wahl, 2006). La interacción de p53 con proteínas que regulan su función, bien directamente o a través de la regulación de la estabilidad de p53, parece ser la clave para encender o apagar la respuesta de p53 (Horn and Vousden, 2007).

\subsection{Respuestas celulares tras daño en el DNA mediada por p53}

Todos los procesos para activar y estabilizar p53 influyen en la vida media de p53 que aumenta de 6-20 minutos a horas, y se traduce en un aumento de la concentración de la proteína en la célula, de 3 a 10 veces más. Y por otro lado también aumenta la posibilidad de unirse a secuencias específicas del DNA (explicado anteriormente) y de promover, de esta manera, la transcripción de genes diana. 
Los diferentes tipos de estrés celular a los que responde p53 tienen una cosa en común, todos son capaces de interrumpir la duplicación de la célula lo que resulta en una disminución de la tasa de mutaciones o aneuploidía durante la división celular. Y todos al final de la cascada de la transducción de señales inducen procesos celulares que permiten a la célula responder de forma adecuada. En un principio, en la respuesta celular tras daño en el DNA, p53 favorece los procesos de supervivencia induciendo la parada de ciclo celular o la reparación del DNA. Tras la acumulación de un daño excesivo en el DNA p53 elimina las células dañadas promoviendo los procesos de apoptosis o senescencia (Helton and Chen, 2007). Así pues, tras su activación, p53 tiene la capacidad de decidir entre la vida y la muerte de una célula. Por eso, en células normales, no dañadas, es muy importante tener p53 bajo control para evitar la muerte celular inútil.

Existen también evidencias de que p53 modula la respuesta ante el daño en el DNA a través de mecanismos independientes de su actividad transcripcional, como es la inducción directa de apoptosis en el citosol (Marchenko et al., 2000).

\subsubsection{Parada del Ciclo Celular}

El ciclo celular es un proceso complejo y está regulado por múltiples factores como son las ciclinas y sus correspondientes quinasas dependientes de ciclinas (CDKs), y los inhibidores de las CDKs que son los componentes relevantes en el proceso de la parada del ciclo celular (Malumbres and Barbacid, 2009). La terminación correcta del ciclo celular está vigilada y controlada en los puntos de control del ciclo celular que bloquean la progresión si se detectan daño en el DNA. En un primer momento, en la respuesta tras daño en el DNA las vías de ATM y ATR inician un arresto del ciclo celular temporal. En esta deceleración inicial de la progresión del ciclo celular se activa p53 por estas quinasas (las quinasas del daño al DNA) e induce genes necesarios para detener del ciclo celular. Entre esos genes se encuentran muchos de los puntos de control que se producen en G1, S y G2/M.

$\mathrm{p} 21^{\mathrm{WAF} / \mathrm{CP} 1}$ es la diana más conocida de p53, que inducida por p53 para inhibir el ciclo celular es capaz de inducir tanto la parada en la fase G1 como en la fase G2 del ciclo celular mediante la inhibición de las uniones entre ciclinaE y CDK2 y entre ciclinaB y Cdc2 (Agarwal et al., 1995; Bunz et al., 1998; Kastan et al., 1991). Cdc2, también conocido como CDK1, es necesario para la entrada en la mitosis. Tras irradiación Cdc2 está reprimida de manera dependiente de p53 tanto a nivel de RNA 
como a nivel de proteínas. p2 $1^{\text {WAF1/CIP1 }}$ va estar implicada en esta regulación negativa de Cdc2 mediada por p53 (Azzam et al., 1997). Además, p21 ${ }^{\text {WAFI/CIP1 }}$ está implicada en la activación de la vía supresora de tumores de la proteína retinoblastoma (pRB). pRB se inactiva por la hipofosforilación mediada por las ciclinas/CDKs durante el proceso del ciclo celular. Tras su inducción, p21 inhibe la unión de la ciclinaE con CDK2, lo que provoca la hiperfosforilación de $\mathrm{pRB}$. Esto permite que RB una a E2F para inhibir la transcripción de los genes del ciclo celular mediada por E2F. Por todo ello, se puede decir que p21 forma parte de las dos vías de supresores tumorales que se activan tras estrés celular (Stewart et al., 2001).

Otro gen también inducido por p53, es 14-3-3 $\sigma$ que forma parte de una familia de proteínas que regulan la actividad celular mediante la unión y el secuestro de proteínas fosforiladas. Una vez inducida tras daño en el DNA, 14-3-3 $\sigma$ inactiva Cdc25 y $\mathrm{Cdc} 2$, secretándolas al citoplasma para inducir el bloqueo pre-mitótico en la fase G2/M (Chan et al., 1999; Lopez-Girona et al., 1999).

\subsubsection{Reparación del daño}

El daño en el DNA induce vías celulares que implican la activación de múltiples factores que actúan en paralelo para reparar el daño. En función del tipo de lesión en el DNA las células utilizan diferentes vías de reparación del daño como son la reparación por escisión de nucleótido (NER), la reparación por escisión de bases (BER), la reparación de apareamientos erróneos (MMR), la recombinación homóloga (HR), la síntesis translesión (TLS), y las vías de reparación mediante la unión de terminales no homólogas (NHEJ).

Se ha demostrado la implicación de p53 tanto en el proceso de reparación por escisión de bases (BER) como en el proceso de reparación por escisión de nucleótido (NER). p53 aumenta la NER por la inducción de genes como GADD45, un gen inducido por irradiación en células que tienen p53 (Smith et al., 2000). Por otra parte, la regulación de la reparación tipo BER por p53 está correlacionada con la habilidad de asociarse directamente con la endonucleasa AP (APE) y la DNA polimerasa $\beta$ (DNA pol $\beta$ ). p53 estabiliza la interacción entre la DNA pol $\beta$ y los sitios básicos de DNA (Zhou et al., 2001). Además, la inducción de p53 tras irradiación $\gamma$ va acompañada de un aumento en la actividad de la DNA glicosilasa 3-metiladenina (3-MeAde), la primera enzima que actúa en el proceso de la reparación tipo BER (Zurer et al., 2004). 


\subsubsection{Apoptosis}

La apoptosis es el proceso de muerte celular programado que está conservado durante la evolución para que el organismo pueda eliminar células no deseadas y con daño. Se han descrito dos vías apoptóticas principales en las células de mamíferos: la vía intrínseca y la vía extrínseca.

La vía extrínseca está mediada por las proteínas de la familia de los receptores de muerte, como son Fas/CD95, TNFR y DF-5, y sus respectivos ligandos, como FasL, TNF $\alpha$ y Trail (Peter and Krammer, 2003). Una vez unidos con su ligando, los receptores de muerte forman el llamado complejo DISC (death receptor inducing signaling complex). Este comlejo DISC después induce las caspasas 8 y 10 y así la cascada de caspasas que finalmente lleva al proceso de apoptosis (Chinnaiyan et al., 1995; Kischkel et al., 1995; Wang et al., 2001).

La vía intrínseca de apoptosis está regulado por las proteínas pro- y antiapoptóticas de la familia de Bcl-2 que provoca la despolarización de la membrana mitocondrial, lo que permite la liberación del citocromo c al citoplasma, la formación del apoptosoma y la subsiguiente activación de las caspasas (Nicholson and Thornberry, 2003). Las proteínas de la familia de Bcl-2 se agrupan en tres clases: la de las proteínas anti-apoptóticas con una fuerte homología a Bcl-2 (por ejemplo Bcl- $\mathrm{X}_{\mathrm{L}}$ ), la de las proteínas pro-apoptóticas como son Bax y Bak de tipo "multidominio" con una similitud estructural a Bcl-2 y la de las proteínas pro-apoptóticas de tipo BH3-only que sólo comparten el dominio $\mathrm{BH} 3$ con los miembros de la familia de Bcl-2 (por ejemplo PUMA). El dominio BH3 es el dominio necesario para la actividad pro-apoptótica y la heterodimerización y está presente en todos los miembros de la familia (Cory and Adams, 2002; Kelekar and Thompson, 1998).

La permeabilidad mitocondrial está determinada por el balance entre las proteínas pro-apoptóticas Bax/Bak y las proteínas anti-apoptóticas Bcl-2/Bcl-X $\mathrm{L}$. La actividad de estas proteínas está regulada positiva o negativamente por las proteínas BH3-only. La apoptosis ocurre cuando el equilibrio entre las proteínas pro- y antiapopticas se rompe por la acumulación de las proteínas activas BH3-only. Esto resulta en un predominio de las proteínas Bax/Bak, que permeabilizan la membrana mitocondrial para liberar los factores pro-apoptóticos. Uno de estos factores es el citocromo c, que actúa con el adaptador de muerte celular Apaf-1 para inducir la activación de la caspasa 9. Esta caspasa es una cisteína proteasa que inicia una cascada 
proteolítica que incluye a las caspasas 3 y 7 . Una vez activadas, las caspasas dirigen la muerte celular ordenada y la eliminación de la célula (Lowe et al., 2004).

Varios miembros de estas dos vías están inducidos por p53, como por ejemplo las proteínas pro-apoptóticas Bax, Bid, Puma y Noxa (Fridman and Lowe, 2003; Miyashita and Reed, 1995), las proteínas de la maquinaria efectora de apoptosis (por ejemplo Apaf-1) (Vogelstein et al., 2000). Además, p53 puede facilitar directamente la liberación del citocromo c (Mihara et al., 2003).

La apoptosis dependiente de p53 es clave para su función supresora de tumores (Gottlieb and Oren, 1996; Gottlieb and Oren, 1998; Hemann et al., 2004; Schmitt et al., 2002).

\subsubsection{Senescencia}

La senescencia es un proceso caracterizado por una parada irreversible del ciclo celular en la fase G1 (Vaziri and Benchimol, 1996), que lleva consigo cambios morfológicos, metabólicos y cambios en la expresión de los genes (por ejemplo $\beta$-galactosidasa). La inducción de senescencia depende de p53 y de los inhibidores del ciclo celular como p21 y p16 (Zhivotovsky and Kroemer, 2004), y puede ser causada por la pérdida de los telómeros o la activación de oncogenes como Ras (Serrano et al., 1997). Así, se puede distinguir entre la senescencia replicativa y la senescencia inducida por oncogenes.

\section{5. p53 y Cáncer}

Como se ha comentado y explicado anteriormente, en una célula normal p53 es clave en la regulación de un amplio rango de procesos celulares como son el control del ciclo celular, la reparación del DNA, la diferenciación, la angiogénesis, la senescencia, etc (Levine, 1997). Así pues, alteraciones en los componentes anteriores o posteriores en la vía de acción de p53 conducirían a una desregulación de estos ciclos celulares, a la inestabilidad genómica y al desarrollo del cáncer. No cabe duda, por tanto, de que la pérdida de expresión de p53 constituye un paso importante en el proceso de transformación celular.

p53 es el gen supresor de tumores más estudiado. Casi todos los tipos cancerosos humanos tienen algún tipo de alteración en la vía de acción de p53, lo cual indica que la pérdida de su función es un paso crítico en la progresión tumoral (Greenblatt et al., 1994). Aproximadamente el $50 \%$ de los tumores tienen mutaciones que inactivan el gen 
TP53. El 50\% restante de los tumores retienen el gen pero la mayoría tienen la función de p53 bloqueada debido a la mutación de los componentes de la vía de p53, como ocurre por ejemplo si ARF está mutado (Prives and Hall, 1999; Sharpless and DePinho, 1999; Woods and Vousden, 2001). Muchas de las mutaciones descritas en p53 se han relacionado con el síndrome de Li-Fraumeni. Los individuos afectados por este síndrome desarrollan tumores específicos a edades más tempranas de lo normal (Malkin et al., 1990; Srivastava et al., 1990).

En consecuencia, muchos grupos de investigación se centraron en estudiar la función de p53 en modelos animales. Así, varios grupos diferentes describieron el desarrollo de ratones deficientes de p53 en la línea germinal (Donehower et al., 1992; Gondo et al., 1994; Jacks et al., 1994; Purdie et al., 1994; Tsukada et al., 1993). Estos ratones $\mathrm{p} 53^{-/}$son viables, pero susceptible a desarrollar tumores espontáneos en edades tempranos. Los ratones deficientes de p53 desarrollan tumores a una edad media de 6 meses (aunque con variaciones dependiendo del background genético del ratón), mientras que los ratones heterocigotos para p53 tienen un retraso comparativo en la aparición de tumores (Donehower et al., 1992; Donehower et al., 1995; Harvey et al., 1993). Entre estos tumores que desarrollan los ratones $\mathrm{p} 53^{-/-}$se encuentran con una gran incidencia los linfomas, normalmente del timo (Donehower et al., 1992; Donehower et al., 1995; Harvey et al., 1993; Jacks et al., 1994; Purdie et al., 1994). Al contrario, los ratones heterocigotos para p53 desarrollan sarcomas en la mayoría de los casos y linfomas (Donehower et al., 1995; Harvey et al., 1993; Jacks et al., 1994). Muchos de estos tumores se han observado también en los individuos afectados por el síndrome LiFraumeni (Donehower, 1996).

A día de hoy existen también modelos cancerosos de ratones con una versión de p53 condicional con los que se pueden hacer experimentos induciendo o apagando la actividad de p53 con el uso de estímulos exógeno (Martins et al., 2006; Ventura et al., 2007; Xue et al., 2007). Así, estos investigadores son capaces de inducir cánceres con p53 apagado y posteriormente inducir la expresión de la proteína para estudiar el efecto de la recuperación de la función de p53. En estos ratones se ha observado que p53 es capaz de eliminar los tumores - hepatocarcinoma, linfoma y sarcoma - que se habían formado antes (Ventura et al., 2007; Xue et al., 2007).

Similarmente, estudios relativamente recientes han confirmado la importante función de p53 en la supresión de tumores y en la resistencia al cáncer, utilizando un modelo transgénico de ráton que tiene un alelo de p53 más de lo normal. Estos ratones, 
llamados "super p53", tienen una respuesta aumentada al daño en el DNA, y por tanto son resistentes a formar tumores (Garcia-Cao et al., 2002).

A pesar de que en las últimas décadas se ha acumulado un enorme conocimiento en relación con los mecanismos que llevan al desarrollo y a la progresión del cáncer, en los que está implicado p53, poco se sabe todavía de los mecanismos que gobiernan la diseminación tumoral (Mehlen and Puisieux, 2006). La invasión local está considerada como el evento inicial y esencial para el proceso de metástasis en carcinomas (Christofori, 2006; Gupta and Massague, 2006). Esta invasión tumoral parece estar controlada por una serie coordinada de procesos celulares y moleculares que permiten a las células tumorales diseminarse y migrar del tumor primario. Durante estos procesos, las células cancerosas parecen perder sus propiedades de adhesión celular y están sujetas a cambios en su fenotipo, debido a un proceso llamado transición epitelio mesenquimal (EMT) (Christofori, 2006; Gupta and Massague, 2006; Nieto, 2002; Thiery, 2002).

\section{La transición epitelio mesenquimal (EMT)}

La EMT es un proceso por el cual las células epiteliales se transforman en células mesénquimales (Figura 6), las cuales así pueden migrar a través de la matriz extracelular (Hay, 1995). Este proceso es esencial durante la embriogénesis (BarralloGimeno and Nieto, 2005) y, como hemos comentado previamente, también se va a activar en situaciones patólogicas como son la fibrosis y el desarrollo tumoral, en cuyo caso puede dar lugar a metástasis (Gupta and Massague, 2006; Thiery, 2003).

La pérdida de la adhesión celular y de la polaridad ápico-basal celular, así como el aumento en la movilidad de las células, son características típicas de la EMT (Thiery, 2003). La adhesión celular y la polaridad del epitelio dependen de la formación de uniones celulares adherentes, en las que la E-caderina es un determinante clave que proporciona la estructura física tanto para las uniones célula-célula como para el reclutamiento de complejos de señalización (Knust and Bossinger, 2002; Perez-Moreno et al., 2003). Así pues, la E-caderina es un guardián importante del fenotipo epitelial, y la pérdida de la función de ésta es uno de los primeros pasos en la inducción de la EMT (Jeanes et al., 2008; Peinado et al., 2004b). La caracterización de la regulación de Ecadherina durante el proceso de la EMT ha supuesto un avance importante en el 
conocimiento de los mecanismos moleculares que están envueltos en la pérdida de la adhesión celular y en la adquisición de propiedades migratorias durante la progresión de los carcinomas (Peinado et al., 2007).

Hoy en día, se ha demostrado que diferentes señales extracelulares pueden provocar la desdiferenciación epitelial y la EMT, como son el factor de crecimiento tumoral (TGF- $\beta$ ), Notch, el factor de crecimiento de los fibroblastos (FGF) y las vías Wnt (Barrallo-Gimeno and Nieto, 2005; De Craene et al., 2005; Huber et al., 2005; Thiery and Sleeman, 2006). La señalización mediada por los receptores en respuesta a estos ligandos promueve la activación de moléculas intracelulares efectoras, como son los miembros de la familia GTPasa - Ras, Rho y Rac - y los miembros de la familia Src de tirosin-kinasas. Estos efectores dirigen la degradación de los complejos de unión y los cambios en la organización del citoesqueleto (Thiery and Sleeman, 2006). Muchas de las señales que inducen la EMT ejercen su acción modulando la expresión de factores de transcripción que reprimen genes epiteliales. En consecuencia, se reprime la expresión de E-caderina, una diana central de estos reguladores transcripcionales. La Ecaderina y la $\beta$-catenina interactúan en las uniones adherentes y en las uniones estrechas para mantener el fenotipo epitelial. Así pues, una limitación en el nivel de E-caderina resulta en la pérdida de estos complejos intracelulares de uniones epiteliales dependientes de E-caderina, y en la translocación de la $\beta$-catenina de la membrana celular al citoplasma donde se degrada o ubiquitina, o al núcleo donde puede regular la transcripción de genes e inducir la EMT (Acloque et al., 2008). Todo esto activa programas transcripcionales que determinan la movilidad mesenquimal y un fenotipo invasivo (Peinado et al., 2007; Thiery and Sleeman, 2006).

En estos procesos están implicados varios factores transcripcionales, y entre ellos se encuentran dos miembros de la familia Snail, Snail (Batlle et al., 2000; Cano et al., 2000) y Snai2 (Bolos et al., 2003; Hajra et al., 2002), que son considerados reguladores claves de la EMT (Nieto, 2002). 


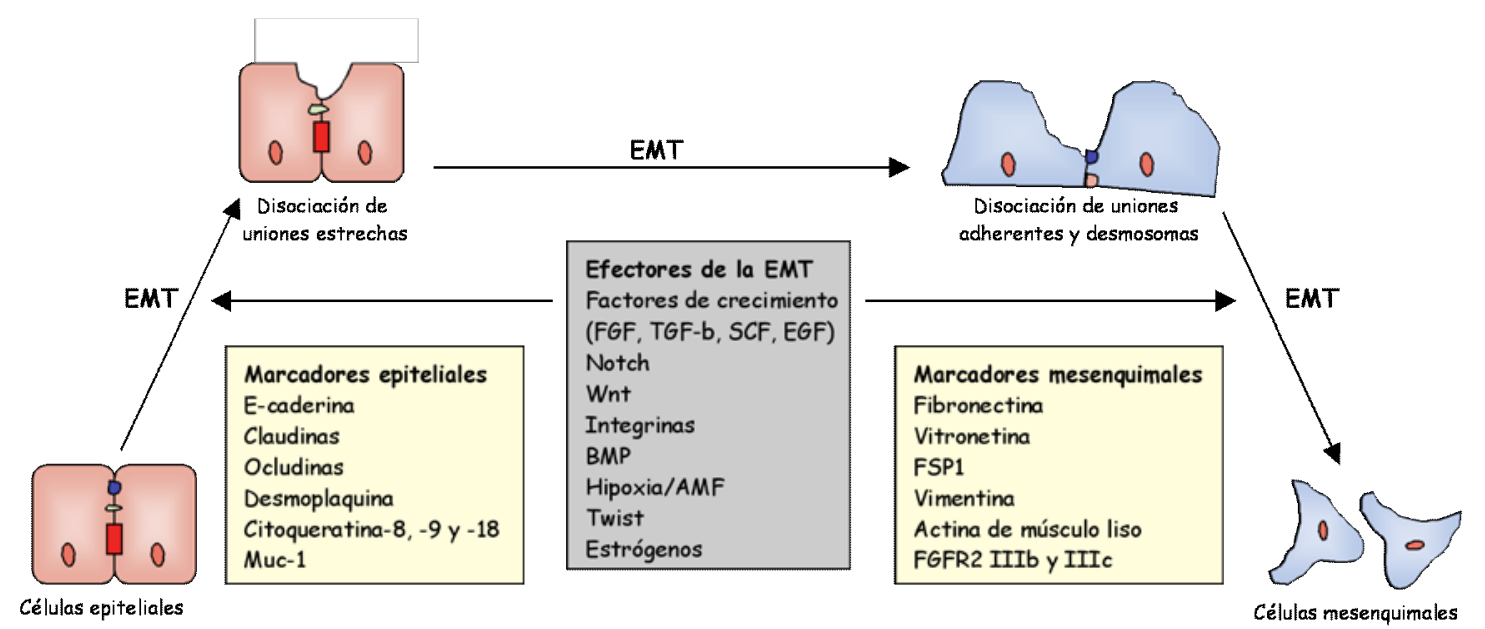

Figura 6: Plasticidad de las células epiteliales durante la transición epitelio mesenquimal (EMT): Durante el proceso de la EMT las células epiteliales se transforman en células mesenquimales. Los diferentes pasos durante la EMT están regulados por efectores de la EMT. Se han identificados diferentes marcadores que son característicos para las células epiteliales y para las células mesenquimales (listados en los recuadros). FGF, factor de crecimiento de fibroblastos; TGF- $\beta$, factor de crecimiento tumoral- $\beta$; AMF, factor de motilidad autocrino; SCF, factor de célula stem; EGF, factor de crecimiento epidérmico; BMP, proteína morfogenética de hueso; FGFR2, receptor del factor de crecimiento de fibroblastos-2; FSP1, proteína específica de fibroblastos-1. Figura modificada de (Thiery and Sleeman, 2006).

\section{La familia Snail}

\subsection{Clasificación y evolución filogenética}

El primer miembro de la familia Snail que se descubrió fue el miembro snail, y fue descrito en Drosophila melangonaster (Boulay et al., 1987; Grau et al., 1984). Posteriormente, se han encontrado homólogos de Snai1 en muchas especies incluyendo los humanos, otros vertebrados (aves, peces, anfibios y mamíferos), protocordados, insectos (snail, escargot, worniu y scratch), nemátodos, anélidos y moluscos (Ashraf et al., 1999; Corbo et al., 1997; Kataoka et al., 2000; Langeland et al., 1998; Roark et al., 1995; Sefton et al., 1998; Wada and Saiga, 1999; Whiteley et al., 1992).

Los genes de la familia Snail de vertebrados fueron inicialmente subdividos en dos subfamilias: la subfamilia Snai1 y la subfamilia Snai2. Posteriormente, se describió otro miembro, Snai3. En vertebrados, cada especie normalmente posee al menos una copia del gen Snail y una del gen relacionado llamado Snai2.

La familia Snail es una de las familias de la superfamilia Snail. Así pues, existen dos familias relacionadas pero al mismo tiempo independientes en la superfamila Snail, que son la famila Snail y la familia Scratch (Manzanares et al., 2001; Nieto, 2002). Esta clasificación tiene además una base filogenética ya que la comparación de las 
secuencias de todas las proteínas pertenecientes a la superfamilia Snail permite diferenciar estos dos grupos (Manzanares et al., 2001).

Debido al incremento en el número de miembros pertenecientes a la familia Snail el comité de nomenclatura génica HUGO ha establecido unas normas para su designación (http://www.gene.ucl.ac.uk/nomenclature/genefamily/snail.htm), de manera que el primer miembro descrito en cada especie será llamado Snail, y los siguientes serán llamados Snai2, Snai3 hasta SnaiX.

\subsection{Estructura}

La comparación de las secuencias proteicas de los miembros de la familia Snail ha permitido conocer las regiones en dedos de zinc e identificar secuencias consenso dentro de cada uno de los dedos de zinc que nos permiten distinguir las familias Snail y Scratch, y también otras que son comunes en todas ellas (Manzanares et al., 2001). Así, dentro del dominio con dedos de zinc, el tercer y el cuarto dedo muestran un consenso común en todos los miembros de la superfamilia Snail, mientras que el segundo y el quinto van a ser los que permitan incluirlos en una u otra familia (Snail o Sratch) (Figura 7). Las proteínas con dedos de zinc de la familia Snail constituyen un grupo mucho más heterogéneo que la familia Scratch con respecto a sus relaciones filogenéticas (Manzanares et al., 2001).

Si nos centramos en la familia Snail de vertebrados (constituida por Snai1, Snai2 y Snai3) se observa que todos los miembros de la familia comparten una organización similar, estando formados por una región carboxi-terminal altamente conservada, que contiene de cuatro a seis de estos dominios en dedos de zinc, y una región aminoterminal mucho más divergente (Hemavathy et al., 2000a; Manzanares et al., 2001; Nieto, 2002).

El número de dedos de zinc en la familia Snail varía entre cuatro y seis, y son todos del tipo $\mathrm{C}_{2} \mathrm{H}_{2}$, donde la $\mathrm{C}$ y la $\mathrm{H}$ son residuos cisteína e histidina, que constituyen la estructura de unión al zinc (Hemavathy et al., 2000a; Manzanares et al., 2001; Nieto, 2002). La presencia de un elevado número de dedos de zinc se debe a que normalmente son necesarios para la unión a secuencias específicas del DNA y con elevada afinidad (Mackay and Crossley, 1998), lo que va a ser importante para su función como represores transcipcionales (Batlle et al., 2000; Cano et al., 2000; Fujiwara et al., 1998; 
Fuse et al., 1994; Hemavathy et al., 2000a; Kataoka et al., 2000; LaBonne and BronnerFraser, 2000; Mayor et al., 2000; Nakayama et al., 1998).

Fuera de la región carboxi-terminal los grados de homología son menores, aunque existe una pequeña región cercana al extremo $\mathrm{N}$-terminal, rica en aminoácidos básico, con una alta homología: es la región NT en el caso de las proteínas descritas en Drosophila, o el dominio SNAG en el caso de las proteínas Snail de vertebrados (Figura 7).

Los miembros de la subfamilia Snai2 constituyen el subgrupo más homogéneo y con más homología entre sí que con el resto de proteínas Snail de vertebrados (mayor del $90 \%$ entre ellas). Su aparición probablemente sea debida a una única duplicación temprana del gen Snail en la línea evolutiva de vertebrados (Manzanares et al., 2001). En concreto esta subfamilia Snai2 tiene un trecho de 29 aminoácidos característicos justo antes del dominio con dedos de zinc denominado dominio Snai2 (Figura 7), y que podría ser considerado una señal para identificar las proteínas Snai2 (Sefton et al., 1998).

Como hemos comentado, la región con dedos de zinc es necesaria para la actividad represora de estos factores transcripcionales, sin embargo, no va ser suficiente, puesto que también participa en ella el llamado dominio SNAG (MPRSFLVK), (Hemavathy et al., 2000a; Hemavathy et al., 2000b) (Figura 7), y que es un motivo importante para la represión en células de mamífero (Nakayama et al., 1998).

La proteína Snai1 de Drosophila, a pesar de no tener el dominio SNAG, también actúa como represor transcripcional gracias a la interacción con el co-represor dCtBP

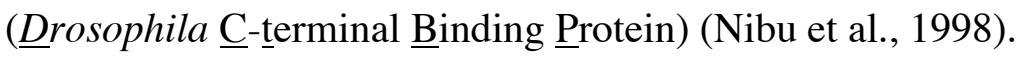

Otra característica a destacar es que la porción central de la mitad N-terminal de la mayoría de los miembros de la familia es rica en Ser/Pro (Hemavathy et al., 2000a), y en el caso de Snail se ha demostrado que está implicada en la localización subcelular de la proteína (Dominguez et al., 2003). 


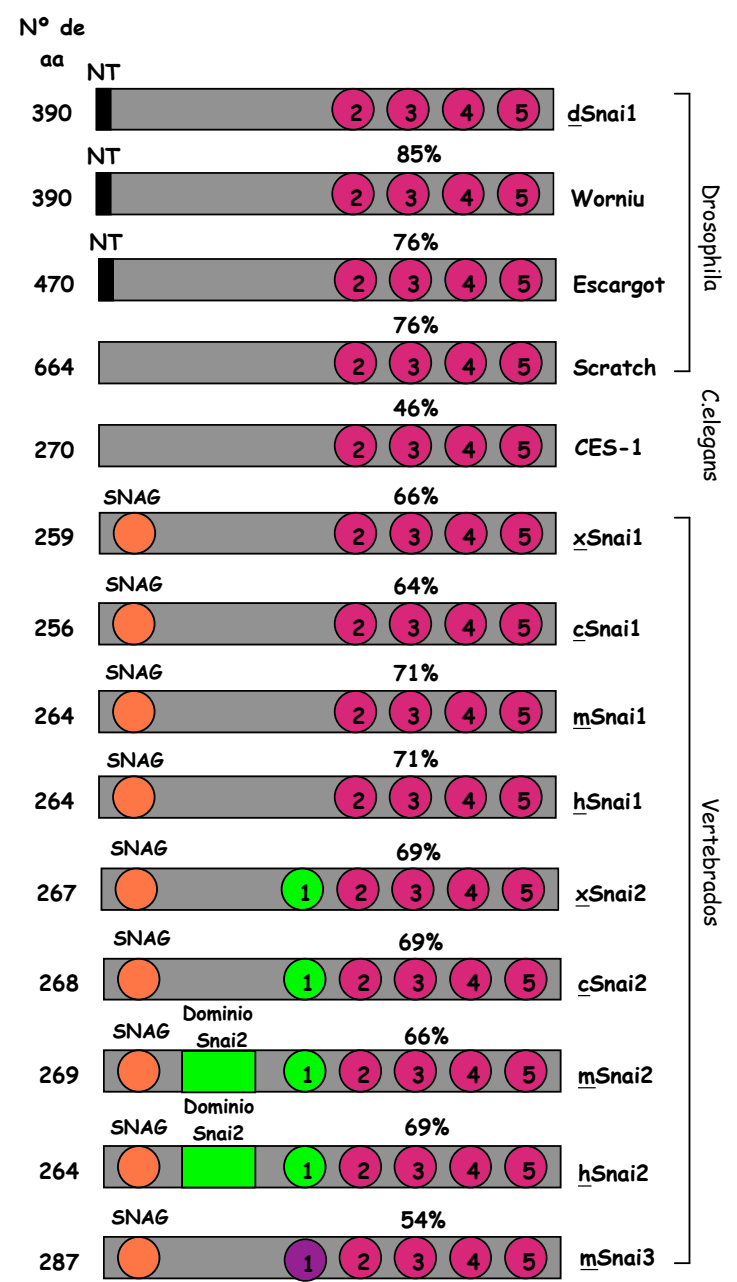

Figura 7: Representación esquemática de diferentes proteínas de la familia Snail (representadas con barras grises) y sus dominios específicos de distintos grupos animales y el tanto por ciento de homología de los dominios de dedos de zinc respecto a los de Snai1 de Drosophila. En los miembros de vertebrados, se ha añadido la primera letra de la especie para indicar la especie en la que se ha aislado el gen. Las proteínas de la familia Snail de vertebrados contienen el dominio SNAG descrito por primera vez en la proteína Gfi-1 (círculo naranja), mientras que las de Drosophila tienen el dominio NT. Características de los miembros de la subfamilia Snai2 son la presencia de un dominio Snai2 (recuadro verde claro) y la secuencia del primer dedo de zinc (verde claro). El primer dedo de zinc de mSnai3 también va a ser diferente (violeta). Abreviaturas de las especies representadas: $\underline{h}$ (humano), $\underline{m}$ (ratón), $\underline{c}$ (pollo), $\underline{x}$ (xhenopus), $\underline{d}$ (drosophila). Escargoty Scratch son proteínas de Drosophila, CES-1 de Caenorhabditis elegans. Figura modificada de (Hemavathy et al., 2000a).

\subsection{Regulación}

Los factores de transcripción de la familia Snail pueden ser regulados a nivel transcripcional por gran cantidad de vías, que van a provocar el aumento o la disminución de los niveles de la proteína en cuestión según el caso (De Craene et al., 2005). En el caso de Snai1, se ha observado que su actividad también puede ser regulada post-transcripcionalmente, de manera que va a ser fosforilada en dos sitios localizados en la región rica en Pro/Ser de la proteína. Esta fosforilación regula su localización subcelular (Dominguez et al., 2003; Yook et al., 2005; Zhou et al., 2004), y parece estar mediada por la quinasa GSK3 $\beta$, quien promueve la exportación nuclear de Snai1 y también su degradación mediada por el proteasoma (Yook et al., 2005; Zhou et al., 2004). Otra quinasa que parece estar implicada en uno de los mecanismos de la regulación post-transcripcional de Snai1 es PAK1 (p21-activated kinase). Aunque PAK1 fosforila Snai1 en el extremo carboxi-terminal, esta forforilación controla también su localización subcelular. Al contrario que GSK3 $\beta$, PAK1 favorece la 
localización nuclear de Snai1 y así su actividad como factor de transcripción (Yang et al., 2005). LIV1 también parece favorecer la función de Snail (Yamashita et al., 2004).

La necesidad de mantener estrechamente regulada la expresión de las proteínas de la familia Snail se pone de manifiesto por el hecho de que Snai1 ha demostrado reprimir su propia expresión (Peiro et al., 2006). Snai2 también ha demostrado ser capaz de unirse a su propio promotor, pero al contrario de lo que ocurre con Snai1, su unión va a favorecer su propia expresión (Sakai et al., 2006).

\subsection{Snai1/Snai2 y la EMT}

Como hemos comentado previamente, el dominio con dedos de zinc funciona como un motivo de unión a secuencias específicas de DNA, que va a ser necesario para su función como represores transcripcionales. Estudios de transfección con promotores de diferentes miembros de la familia han demostrado que el sitio consenso de unión al DNA de las proteínas de la familia Snail contiene 6 bases, CAGGTG (Batlle et al., 2000; Cano et al., 2000; Fuse et al., 1994; Inukai et al., 1999; Kataoka et al., 2000). Este motivo es idéntico a las secuencias denominadas E-box (CANNTG), que es el sitio consenso de unión al DNA de los factores de transcripción bHLH (basic helix-loophelix). Esto indica que las proteínas de la familia Snail pueden competir con las proteínas bHLH por las mismas secuencias de unión (Kataoka et al., 2000; Nakayama et al., 1998; Perez-Moreno et al., 2001).

Así pues, las proteínas de la familia Snail, mediante su actividad represora, están implicadas en procesos muy variados y relevantes del desarrollo como es la transición epitelio mesenquimal, fundamental tanto para el desarrollo normal como para el desarrollo tumoral (Hemavathy et al., 2000a; Nieto, 2002) (Figura 8).

Como hemos dicho previamente, Snail fue identificado en Drosophila donde demostró ser esencial durante el desarrollo embrionario para la formación del mesodermo (Alberga et al., 1991; Grau et al., 1984). Este papel de Snai1 está conservado en homólogos de Snai1 en diferentes especies como son los insectos, las ascidias, los anfioxos y también en el desarrollo del mesodermo en vertebrados (Corbo et al., 1997; Langeland et al., 1998; Sommer and Tautz, 1994; Wada and Saiga, 1999). Además de su función para la formación del mesodermo, los miembros de la familia Snail en vertebrados han mostrado ser importantes en el desarrollo de la cresta neural (Gans and Northcutt, 1983). Tanto las células del mesodermo como las de la cresta neural tienen que delaminarse del tejido en que se han originado y migrar para poblar 
diversas partes del embrión y contribuir a la formación de varias estructuras (Nieto, 2002). Esta delaminación está mediada por el proceso de EMT.

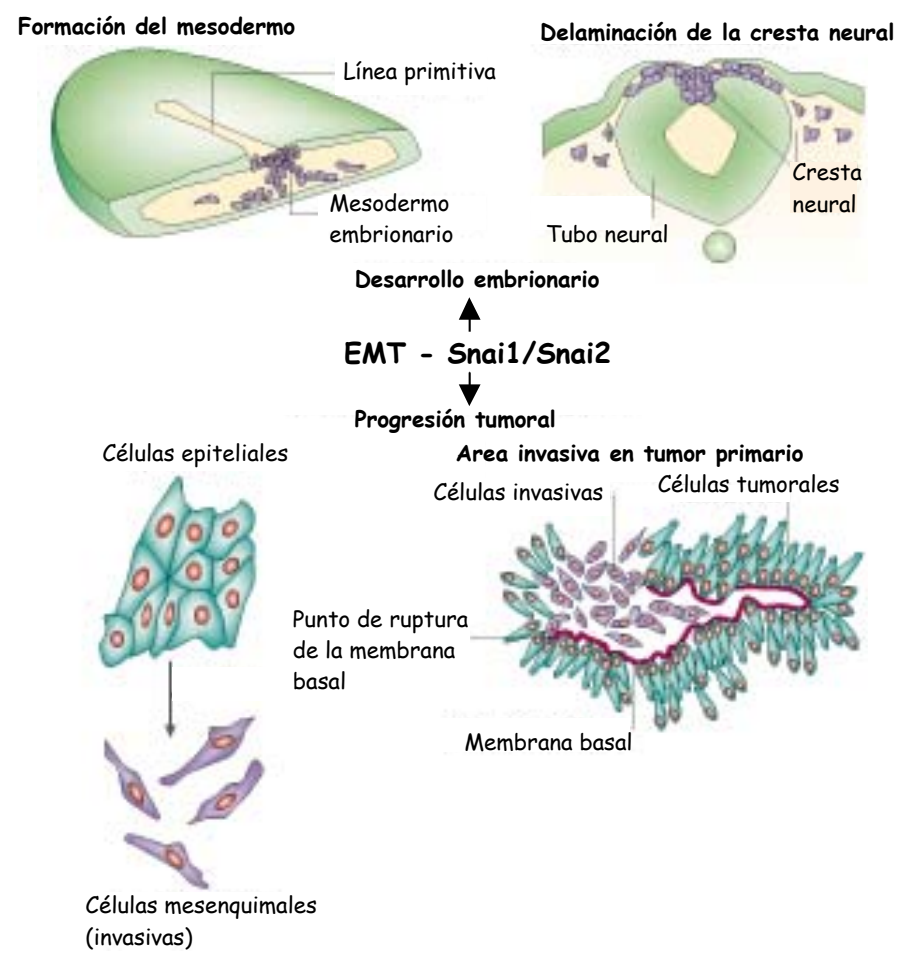

Figura 8: Implicación de Snai1 y Snai2 en la EMT. La EMT no sólo ocurre durante el desarrollo embrionario, sino que también tiene lugar en situaciones patológicas tales como la adquisición de un fenotipo invasivo en los tumores epiteliales, en los cuales es la primera etapa para la generación de las metástasis. Los miembros Snai1 y Snair han sido implicados en ambos situaciones. Figura modificada de (Nieto, 2002)

El papel de Snai1 y Snai2 en la inducción de la EMT no está reducido a la formación del mesodermo y la cresta neural, sino que también se ha observado la expresión de Snai1 y/o Snai2 en otras células que participan en el proceso de EMT durante el desarrollo embrionario de vertebrados, como pasa durante la decondensación de las somitas, la formación del endodermo, la formación de los cojinetes del corazón y el cierre del paladar (Carmona et al., 2000; Martinez-Alvarez et al., 2004; Murray et al., 2007; Romano and Runyan, 2000; Sefton et al., 1998; Timmerman et al., 2004; Veltmaat et al., 2000). Así pues, parece que la EMT es una de las funciones ancestrales asociadas a la familia Snail.

Como hemos comentado anteriormente, moléculas de diferentes vías de señalización pueden inducir el proceso de EMT (De Craene et al., 2005), y todas ellas al final activan a los miembros de la familia Snail (Barrallo-Gimeno and Nieto, 2005; Nieto, 2002). Tras la inducción de la señalización de EMT, las proteínas de la familia Snail reprimen los marcadores epiteliales (Batlle et al., 2000; Cano et al., 2000; Guaita et al., 2002; Ikenouchi et al., 2003; Tripathi et al., 2005a; Tripathi et al., 2005b) y 
aumentan los marcadores mesenquimales (Cano et al., 2000; Guaita et al., 2002), o participan en el cambio de la forma celular y en las propiedades invasivas (del Barrio and Nieto, 2002; Yokoyama et al., 2003).

Uno de los marcadores epiteliales más estudiado en el contexto de la EMT inducida por la familia Snail es la proteína E-caderina. Tanto Snai1 (Batlle et al., 2000; Cano et al., 2000) como Snai2 (Bolos et al., 2003) van a disparar la EMT reprimiendo la expresión del gen E-caderina, aunque parece ser que Snai2 se va a unir con menor afinidad que Snai1 (Bolos et al., 2003). Por tanto, Snai1 y Snai2 son funcionalmente equivalentes como represores de E-caderina, y ambos factores pueden contribuir a la EMT y/o al mantenimiento de un fenotipo mesenquimal/migratorio dependiendo de sus concentraciones relativas y/o del contexto celular y tisular específico (Bolos et al., 2003).

Pero también se ha demostrado que los miembros de la familia Snail participan en algunos movimientos celulares que no necesitan una EMT completa regulando la adhesión celular y la migración (Savagner et al., 1997; Yamashita et al., 2004). Por tanto, el inicio de la EMT podría ser considerado un mecanismo utilizado por los miembros de la familia Snail para promover movimientos celulares (Barrallo-Gimeno and Nieto, 2005).

\subsection{Snail/ Snai2 y supervivencia celular}

Aparte de las funciones que tienen los miembros de la familia Snail en la EMT, hay muchas evidencias que indican que están implicados también en el proceso de protección de las células de la muerte celular.

La función de Snai2 en la supervivencia celular se observó, por primera vez en una línea celular pro-B de ratón, Ba/F3, dependiente de la citoquina IL-3. La retirada de la IL-3 del medio de cultivo de estas células llevaba al suicidio celular por apoptosis. La expresión de Snai2 en estas células permitía a estas células sobrevivir tras la retirada de la IL-3 (Inukai et al., 1999). El mismo papel de Snai2 en supervivencia se vio en linfocitos pro-B humanos durante la hematopoyesis, donde se observó que los linfocitos pro-B defectivos se reprimía la expresión de Snai2 permitiendo inducir así el proceso de apoptosis (Inukai et al., 1999).

Este papel anti-apoptótico de Snai2 se ha observado también en progenitores hematopoyéticos tras daño en el DNA inducido por irradiación gamma, en los que Snai2 participa en una vía de superviviencia que protege a estas células. Esto sucede a 
través de mecanismos que no interfieren con la actividad de p53, lo que se deduce al observar que células hematopoyéticas $\mathrm{Snai2}^{-{ }^{-}}$, a pesar de presentar un mayor porcentaje de apoptosis, parecen regular p53 de forma adecuada en respuesta al daño en el DNA. Así pues, se sugiere que la vía de supervivencia dependiente de Snai2 está en paralelo o por debajo de la vía de regulación de p53 (Inoue et al., 2002; Perez-Losada et al., 2003).

De hecho, se ha observado también que Snai2 es inducido a nivel transcripcional por p53. Esta inducción ocurre en células que han sufrido daño en el DNA por radiación, y hace que estas mismas células esten protegidas de la apoptosis mediante la represión directa de la transcripción de Puma (una proteína pro-apoptótica, como hemos explicado anteriormente) mediada por p53 (Wu et al., 2005).

Otra observación que apoya el papel de Snai2 en la protección frente a la radiación viene de un estudio en el que se ha observado que Snai2 está implicado en la vía de señalización del factor de célula stem/c-kit ( $\mathrm{SCF} / \mathrm{c}-\mathrm{kit})$. Esta vía es importante en la recuperación hematopoyética que previene la muerte celular después de la irradiación letal. La activación de c-kit por SCF también va a inducir la expresión de Snai2 para que así ejerza su papel radioprotector (Perez-Losada et al., 2003).

Pero no sólo se ha demostrado una función en la supervivencia celular para Snai2, sino que también ha sido descrita para Snai1, el cual es un potente factor de supervivencia, ya que células que expresan Snai1 sobreviven tras la retirada de factores de supervivencia del medio de cultivo. Además, estas células que expresan Snai1 son resistentes a las señales apoptóticas directas, inducidas por los receptores de muerte y también por daño en el DNA (Escriva et al., 2008; Kajita et al., 2004; Martinez-Alvarez et al., 2004; Vega et al., 2004).

\subsection{Snai1/Snai2 y Cáncer}

Como hemos explicado anteriormente, el cáncer es la consecuencia de una serie de eventos incluyendo la desdiferenciación, la división incontrolada, los cambios en las propiedades de adhesión celular y la invasión. La mayor contribución a la progresión del cáncer es la disminución de la expresión de las moléculas de la adhesión celular, lo que permite cambiar la forma de la célula y que ésta se convierta en metastásica (Takeichi, 1993). Un proceso muy importante en este contexto es la transición epiteliomesénquima (EMT), la cual convierte las células epiteliales en células mesénquimales, como hemos explicado previamente, de manera que estas últimas son capaces de invadir y migrar (Acloque et al., 2008; Thiery, 2002). Los miembros Snai1 (Batlle et al., 2000; 
Cano et al., 2000) y Snai2 (Bolos et al., 2003) de la familia Snail son importantes en el disparo de la EMT que se produce durante el desarrollo embrionario, y también se encuentran entre las proteínas implicadas en este proceso de EMT en condiciones patológicas. Y de hecho, de la misma manera que ocurre durante el desarrollo embrionario, su participación en la EMT en condiciones patológicas también ha sido asociada con la disminución de la expresión de E-caderina, lo que favorece la adquisición de propiedades invasivas y migratorias. Por ello, tanto Snai1 como Snai2 son considerados marcadores de malignidad e indicadores del potencial metastásico de los tumores (Batlle et al., 2000; Blanco et al., 2002; Cano et al., 2000). Así, se ha observado la expresión de Snail en biopsias obtenidas de tumores de pecho (Blanco et al., 2002; Elloul et al., 2005), de cáncer gástrico (Rosivatz et al., 2002), de carcinoma hepatocelular (Miyoshi et al., 2005; Sugimachi et al., 2003), de cáncer de colon (Palmer et al., 2004) y de sarcoma sinovial (Saito et al., 2004).

Snai1 también puede promover la progresión tumoral mediante la activación de angiogénesis (Peinado et al., 2004a), y también parece haber indicaciones de que la eliminación de Snai1 puede invertir la invasión (Olmeda et al., 2007).

Pero no sólo Snai1 está implicado en la progresión tumoral, sino también Snai2, cuya expresión ha sido descrito en carcinoma esofágico (Uchikado et al., 2005), en células de rabdomiosarcoma que expresan la translocación PAX3-FKHR (Khan et al., 1999) y en cáncer de pecho, donde se ha mostrado una cooperación con Snai1 en la inducción de la EMT y donde la expresión de Snai1 está correlacionada con la desdiferenciación y la metástasis (Blanco et al., 2002; Cheng et al., 2001; Elloul et al., 2005), y la expresión de Snai2 con la represión del gen de supresión de tumores BRCA2 (Tripathi et al., 2005b).

Snai2 también se expresa en mesoteliomas malignos, donde está inducido por el factor de célula stem (SCF) (Catalano et al., 2004). Esto está de acuerdo con su descripción como diana de la vía SCF/c-Kit (Perez-Losada et al., 2002). En estos tumores la expresión de Snai2 parece conferir a los pacientes resistencia a los agentes quimioterapeúticos, y esta resistencia estaría de acuerdo con el papel descrito para Snai2 en la protección de las células de la muerte celular (Inoue et al., 2002; Kajita et al., 2004; Perez-Losada et al., 2003).

De la misma manera Snai2 ha sido asociado con las leucemias relacionadas con las proteínas de fusión E2A-HLF (Inukai et al., 1999) y BCR-ABLp190 (Perez-Mancera et al., 2005a), donde ha demostrado ser un factor anti-apoptótico. 
La función anti-apoptótica tanto de Snai1 como de Snai2 incrementa in vitro la resistencia a la muerte celular programada tras daño en el DNA (Kajita et al., 2004) y favorece in vivo el desarrollo de tumores en el ratón (Perez-Mancera et al., 2005a; Perez-Mancera et al., 2005b). Así, los estudios sobre la función de los miembros de la familia Snail en la génesis del cáncer han demostrado que la expresión condicional de Snai1 y Snai2 en ratón produce cáncer (Perez-Mancera et al., 2005a; Perez-Mancera et al., 2005b). Sin embargo, la alteración genética inicial no es requerida para mantener el tumor, lo cual daría a Snai1 y Snai2 una función importante en la transformación celular. Así se ha descrito que Snai2 tiene un papel fundamental en la biología de las células cancerígenas BCR-ABL (Perez-Mancera et al., 2005a), y también que participa en la transformación de los melanocitos (Gupta et al., 2005). Además, la expresión de SLUG está siendo reconocida cada vez más como una alteración en tumores mesenquimales (Inukai et al., 1999; Khan et al., 1999; Perez-Mancera et al., 2005a).

Así pues, podemos decir que los miembros de la familia Snail inducen el proceso de transición epitelio mesenquimal (EMT), y que su expresión está regulada tras daño en el DNA de manera que actúan como factores anti-apoptóticos, lo cual conferiría a las células una ventaja selectiva para la migración celular y facilitaría la delaminación del tumor primario y su metástasis a otras partes del cuerpo (BarralloGimeno and Nieto, 2005). Pero también participan en la génesis del cáncer, donde la supervivencia conferida a las células como consecuencia de la existencia de anomalías cromosomicas que van a dar lugar a las proteínas de fusión oncogénicas capaces de activar dianas como Snai1 y Snai2 permitiría la acumulación de otras lesiones.

\subsection{Snai3, otro miembro de la familia Snail}

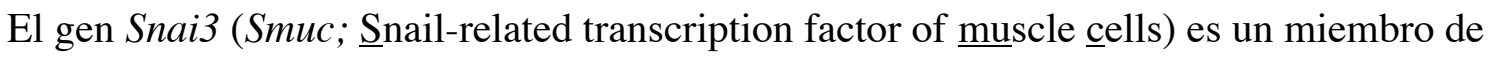
la familia Snail de factores de transcripción con dedos de zinc (Nieto, 2002), como hemos explicado previamente.

Este gen Snai3 fue descrito inicialmente en el ratón (Kataoka et al., 2000), y recientemente se ha descrito en los humanos (Katoh and Katoh, 2003), y en otras especies de vertebrados (Manzanares et al., 2004). El gen Snai3 está formado por 3 exones, se localiza en el cromosoma 8 en el genoma del ratón y en el cromosoma 16 en los humanos, y codifica para una proteína de 287 aminoácidos (Kataoka et al., 2000).

El gen Snai3 fue considerado un miembro de la familia Snail debido a su homología con los genes Snail y Snai2 (Kataoka et al., 2000). La proteína Snai3 tiene 5 
dominios en dedos de zinc, pareciéndose más así a Snai2 que a Snai1 que sólo tiene 4, y también se observa la presencia del llamado dominio SNAG que está presente en todos los miembros de la familia Snail de vertebrados (Figura 9).

De esta manera, Snai3 cumple todos los requisitos necesarios para considerarse como un nuevo miembro de esta familia. Sin embargo, el gen Snai3 ocupa una posición inusual en el árbol filogenético de las proteínas Snail de vertebrados, lo que podría indicar que la proteína posee una función diferente a la de los otros miembros de la familia.

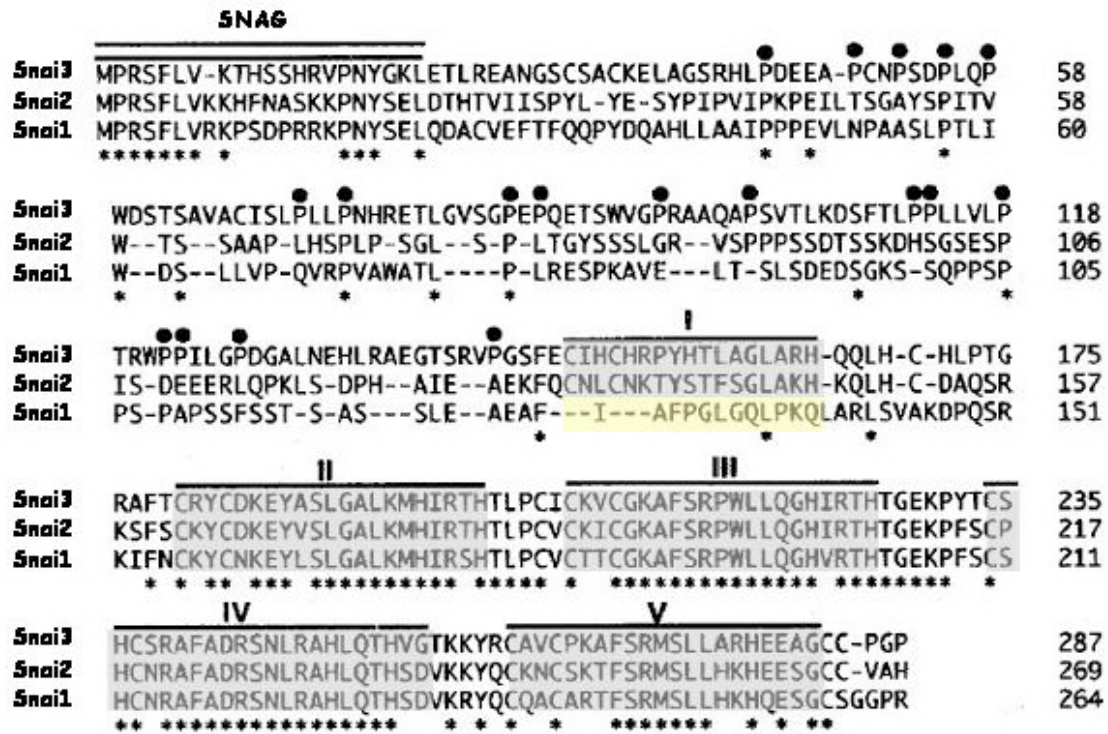

Figura 9: Secuencia de aminoácidos de Snai3 comparada con la de Snai1 y Snai2 de ratón. Los residues que son idénticos en las tres especies están marcados con un asterisco. El dominio de Snai3 que no tiene dedos de zinc es rico en residuos de prolina que se indican con un círculo. Los aminoácidos que se corresponden con los dominios de dedos de zinc se indican con una línea. Los aminoácidos conservados de la región amino terminal están marcados con una línea doble. Modificado de (Kataoka et al., 2000).

Los estudios sobre Snai3 realizados hasta la fecha, han permitido conocer, además de su secuencia y estructura, su expresión durante el desarrollo embrionario y en diversos tejidos adultos de ratón como son el músculo esquelético, el sistema cardiovascular y el sistema inmune (Kataoka et al., 2000). Al igual que las proteínas Snai1 y Snai2, Snai3 es un regulador de procesos de diferenciación dependientes de secuencias E-box ya que se expresa durante el desarrollo embrionario, y mediante su unión a secuencias específicas de DNA posee actividad represora mediada tanto por el dominio SNAG como por los dominios en dedos de zinc (Kataoka et al., 2000). Sin 
embargo, se desconoce el papel que Snai3 desempeña en las funciones que realizan Snai1 y Snai2: EMT y la nueva función emergente en la génesis del cáncer. 
HIPÓTESIS DE TRABAJO 
El gen Snai3 es un miembro de la familia Snail de factores de transcripción, cuyos integrantes codifican para factores de transcripción con dedos de zinc (Nieto, 2002). Todos ellos comparten una organización similar, estando formados por una región carboxi-terminal altamente conservada, que contiene de cuatro a seis de dominios en dedos de zinc, y una región amino-terminal mucho más divergente. La función de los dedos de zinc es la de unirse a secuencias específicas de DNA denominadas secuencias E-box, y a través de esta unión las proteínas de la familia Snail van a estar implicadas en procesos muy variados y relevantes del desarrollo, como es la transición epitelio mesenquimal (Batlle et al., 2000; Cano et al., 2000; Hajra et al., 2002; Hemavathy et al., 2000a; Nieto, 2002; Perez-Mancera et al., 2005b).

En lo que concierne al gen Snai3, se describió inicialmente en el ratón (Kataoka et al., 2000), y recientemente se ha descrito en los humanos (Katoh and Katoh, 2003) y en otras especies en vertebrados (Manzanares et al., 2004). Fue considerado un miembro de esta familia de factores de transcripción debido a su homología con los miembros Snai1 y Snai2 (Kataoka et al., 2000).

Como hemos explicado en detalle anteriormente, de los miembros Snai1 y Snai2 de la familia Snail existen numerosas publicaciones que indican su función en procesos tan importantes como son la transición epitelio mesenquimal (EMT) (Nieto, 2002), importante durante el desarrollo embrionario como durante el desarrollo tumoral, la supervivencia (Inoue et al., 2002; Inukai et al., 1999; Kajita et al., 2004; MartinezAlvarez et al., 2004; Peinado et al., 2003; Perez-Losada et al., 2003; Perez-Losada et al., 2002; Valdes et al., 2004) y la génesis del cáncer (Gupta et al., 2005; Kajita et al., 2004; Perez-Mancera et al., 2005a; Perez-Mancera et al., 2005b), la nueva función emergente de dichos miembros. Sin embargo, se desconoce el papel que Snai3 desempeña en los procesos celulares.

Por ello, quisimos estudiar la función de Snai3 en la transición epitelio mesenquimal (EMT), en la respuesta tras daño en el DNA y en la génesis del cáncer. 
OBJETIVOS 
1. Determinar si Snai3 participa en la transición epitelio mesenquimal (EMT).

2. Determinar si Snai3 está implicado en los procesos moleculares en respuesta al daño en el DNA.

3. Determinar si Snai3 participa en la génesis del cáncer. 


\section{RESULTADOS}




\section{Función de Snai3 en la transición epitelio mesenquimal (EMT)}

Como hemos explicado anteriormente, los miembros Snai1 y Snai2 de la familia Snail juegan un papel importante en la EMT que se produce tanto durante el desarrollo embrionario como durante la progresión tumoral (Hemavathy et al., 2000a; Nieto, 2002), actuando como represores transcripcionales mediante su unión a secuencias específicas del DNA denominadas secuencias E-box.

Snai3 es considerado otro miembro de la familia Snail debido a su homología con Snai1 y Snai2, pero hasta ahora se sabe muy poco acerca de su función. Por su homología en la secuencia génica y en la estructura proteica con los miembros Snail y Snai2, y por el uso de las secuencias E-box en su unión al DNA, no es ilógico pensar que Snai3 podría ejercer su función biológica en procesos similares a aquellos en los que participan Snai1 y Snai2, como es la transición epitelio mesenquimal.

\subsection{Snai3 reprime el promotor de E-caderina}

Como hemos comentado antes, uno de los primeros e importantes eventos en la inducción del proceso de EMT es la represión de genes epiteliales, como es el gen que codifica para E-caderina, proceso en el que están implicados los miembros Snai1 y Snai2 (Batlle et al., 2000; Bolos et al., 2003; Moreno-Bueno et al., 2006).

Por tanto, puesto que Snai3 cuenta también con el dominio zinc-finger y con el dominio SNAG, y ha mostrado actuar como factor de transcripción utilizando las secuencias E-box para su unión al DNA, quisimos saber si esta proteína también está implicada en la EMT, para lo cual quisimos inicialmente determinar si es capaz de reprimir la expresión de E-caderina. Para ello, utilizamos como contexto celular una línea de células epiteliales de riñón de perro (Madin-ㅁarby canine kidney (MDCK)), que expresan un alto nivel de E-caderina, ya que se ha descrito que tanto Snai1 como Snai2 reprimen la transcripción de E-caderina en esta línea celular (Batlle et al., 2000; Bolos et al., 2003). Para estudiar el efecto de la proteína Snai3 sobre la expresión de Ecaderina realizamos un ensayo Luciferasa, para lo cual transfectamos las células MDCK con el promotor de E-caderina y con Snai3.

En el promotor de E-caderina, tanto en humano como en ratón, se han caracterizado 3 secuencias E-box, a las que se ha descrito la unión de Snai1 y Snai2 (Batlle et al., 2000) (Figura 10A). Este promotor de E-caderina dirige la expresión de un gen reporter de Luciferasa en el vector pGL3 (Batlle et al., 2000). La medida de la cantidad de luminiscencia emitida por la Luciferasa nos va a indicar si el promotor de 
interés está inducido o reprimido en determinadas situaciones celulares. Nuestra referencia fue el vector vacío que nos indica si Snai3 es capaz de reprimir el promotor de E-caderina, siempre y cuando la activación del promotor de E-caderina sea menor que en las células transfectadas sólo con el vector vacío. Como control positivo de represión de E-caderina transfectamos también las células con Snai1 o Snai2.

Como podemos observar en la Figura 10B, Snai3 reprime el promotor de Ecaderina en un $28 \%$ aproximadamente, cuando se compara con la actividad del promotor en las células transfectadas con el vector vacío. Nuestros controles, las células transfectadas con Snai1 o Snai2, también muestran su actividad represora disminuyendo la actividad del promotor de E-caderina en un 32\% ó $43 \%$ respectivamente.

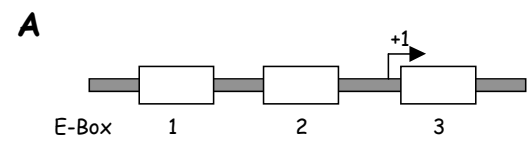

B

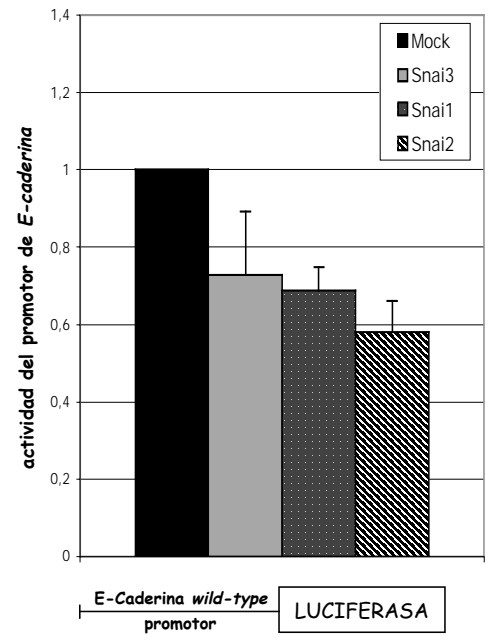

\section{c}

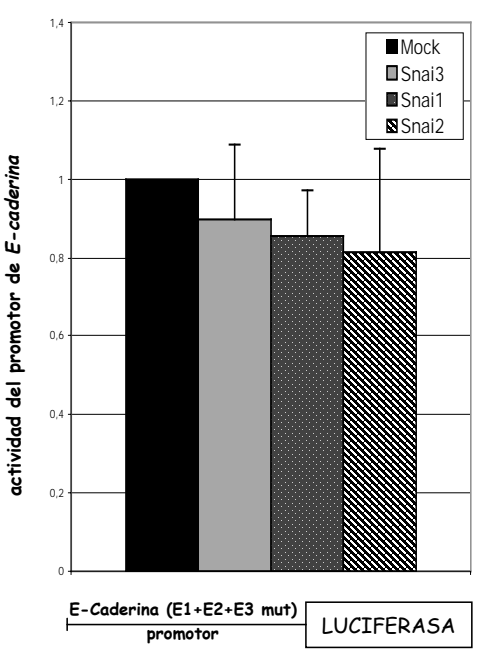

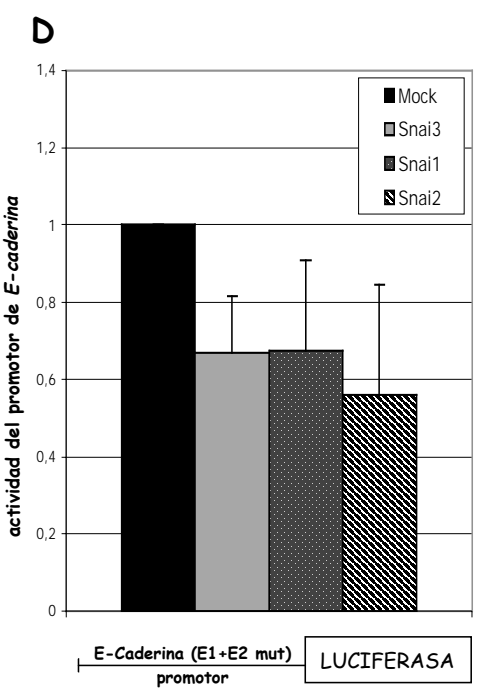

Figura 10: Estudio de la regulación del promotor de E-caderina por Snai3. (A) Esquema del promotor de E-caderina con las 3 secuencias E-Box descritas para la unión de los miembros Snail y Snai2 (Batlle et al., 2000).; Transfectamos células MDCK con el promotor de E-caderina (B) pGL3-Ecad(-178/+92) (wild-type), (C) pGL3-E-cad(E1+E2+E3 mut), (D) pGL3-E-cad(E1+E2 mut), y estudiamos el efecto de Snai3 en la actividad promotora de estas versiones del promotor co-transfectando dichas células con pcDNA3-Snai3, pcDNA-Snai1, pcDNA-Snai2 o con el vector pcDNA3 vacío (1ug). La actividad del promotor fue medida 48 horas después de la transfección mediante un ensayo Luciferasa. Para la normalización de los resultados fue utilizado el vector pRL-SV40 (1 $\mu$ g). Cada resultado es la media de $(\boldsymbol{A}+\boldsymbol{C}) 3$ ó (B) 5 experimentos independientes. 
Para comprobar si Snai3 reprime la expresión del promotor E-caderina mediante la unión a las 3 secuencias de E-Box descritas en este promotor, como ocurre con Snai1 y Snai2 (Batlle et al., 2000; Bolos et al., 2003), realizamos un ensayo Luciferasa utilizando en este caso un promotor de E-caderina que presenta mutadas estas 3 secuencias.

En la Figura $10 C$ podemos observar que Snai3, de la misma manera que nuestros controles Snai1 y Snai2, pierde la capacidad de reprimir el promotor de E-caderina, cuando las 3 secuencias E-Box están mutadas, puesto que se recupera la actividad promotora de E-caderina que va a ser de un $90 \%$ aproximadamente en todos los casos.

Puesto que se ha descrito que la principal secuencia E-Box utilizada tanto por Snai1 como por Snai2 para llevar a cabo la represión del promotor de E-caderina es la E-Box-3 (Batlle et al., 2000; Bolos et al., 2003), realizamos a continuación un nuevo ensayo Luciferasa utilizando un promotor de E-caderina en que únicamente están mutadas las secuencias E-Box-1 y E-Box-2. Mediante este experimento, observamos que Snai3, al igual que los controles Snai1 y Snai2, vuelve a reprimir el promotor de Ecaderina, puesto que los valores de la actividad del promotor de E-caderina bajan de nuevo a un $66 \%$ en el caso de Snai3 y a un $67 \%$ ó $56 \%$ en los casos de Snai1 o Snai2 (Figura 10D).

Por lo tanto, podemos concluir que Snai3, al igual que los miembros Snai1 y Snai2, reprime el promotor de E-caderina en el modelo de las células MDCK.

\subsection{La expresión de Snai3 en células MDCK no induce características mesenquimales}

Como hemos mostrado previamente, Snai3 reprime la actividad del promotor de Ecaderina, lo cual es una de las características en la inducción del proceso de la EMT. Otra característica importante en el proceso de la EMT, como hemos comentado antes, es la adquisición de propiedades mesenquimales, de manera que se produce un cambio en el fenotipo de las células y en el perfil de expresión de marcadores epiteliales y mesenquimales.

Para estudiar si Snai3 también es capaz de inducir estos fenómenos, transfectamos células MDCK de forma estable con Snai3. Para ello, seleccionamos las células transfectadas con Snai3 añadiendo un antibiótico al medio de cultivos, y esperamos hasta que todas las células estaban seleccionadas, para a continuación crecer 
clones únicos mediante el método de dilución límite. De los clones obtenidos congelamos una parte y la otra parte la recogimos para extraer RNA y proteínas.

Uno de los primeros cambios que se puede observar en el cultivo es el cambio en el fenotipo celular, de manera que las células epiteliales en las que se ha inducido la EMT presentan una morfología mesenquimal. Este fenómeno lo observamos de forma muy evidente en uno de los clones de las MDCK transfectadas con Snai3 (Snai3\#18), que se transformó y adquirió un fenotipo mesenquimal, como se aprecia cuando se compara con las células sin transfectar y con las células transfectadas con el vector vacío (Figura 11). En el resto de los clones de las MDCK transfectadas con Snai3 no observamos ese cambio en la forma de las células.

Como control utilizamos las MDCK transfectadas con Snai1 y Snai2, de las que se sabe que inducen la EMT y por ello adquieren propiedades mesenquimales, y como se puede observar también presentan un cambio en el fenotipo de las células (Figura 11).

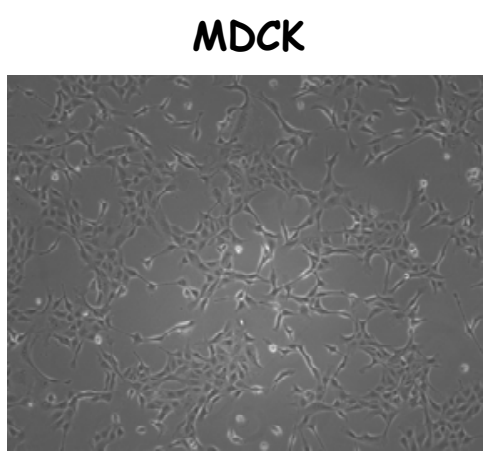

Snai1\#30

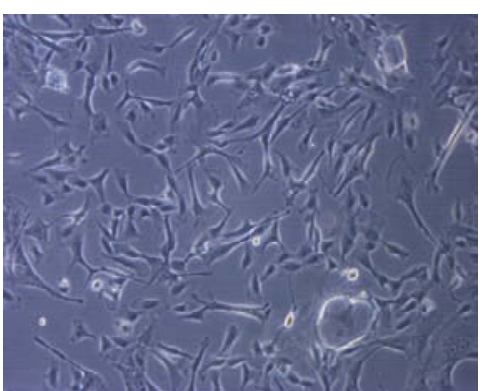

Mock

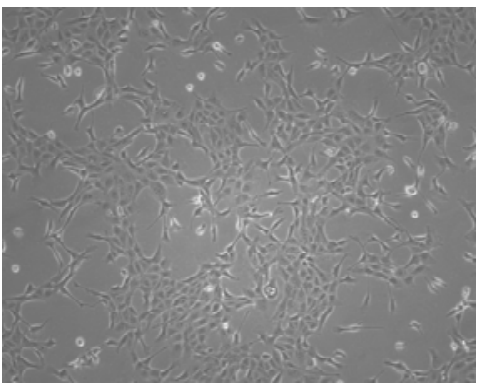

Snai2\#42

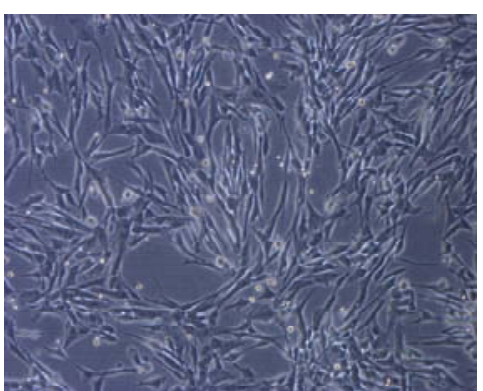

Snai3\#18

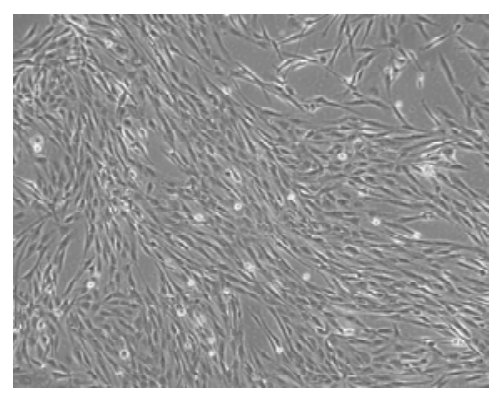

Figura 11: Fenotipo celular de las MDCK transfectadas con Snai1, Snai2 o Snai3. Imágenes del fenotipo celular de los clones de MDCK transfectadas con Snai1, Snai2 o Snai3 que se transformaron en cultivo celular hacía un fenotipo mesenquimal. Como controles de células epiteliales están representadas células MDCK sin transfectar y células MDCK transfectadas con el vector vacío. 
A continuación, quisimos estudiar la expresión proteica de marcadores epiteliales y mesenquimales en los clones de las MDCK transfectadas con Snai3 para saber si alguno de ellos tenía el perfil molecular característico de la EMT. Para ello, obtuvimos el extracto proteico total de todos los clones obtenidos de las MDCK transfectadas con Snai3 y analizamos mediante Western Blot la expresión de Ecaderina, $\beta$-catenina y $\gamma$-catenina (marcadores epiteliales), así como también la expresión de Vimentina (marcador mesenquimal).

La E-caderina es una proteína transmembrana que está unida al citoesqueleto de actina mediante la interacción del dominio intracelular con las cateninas (Figura 12). Así pues, la disminución en la expresión tanto de E-caderina como de $\beta$-catenina y $\gamma$ catenina nos va a indicar un cambio en el perfil de expresión de las células MDCK normales hacia células en las que se ha inducido la EMT, para lo cual va a ser necesario el aumento en la expresión de Vimentina.

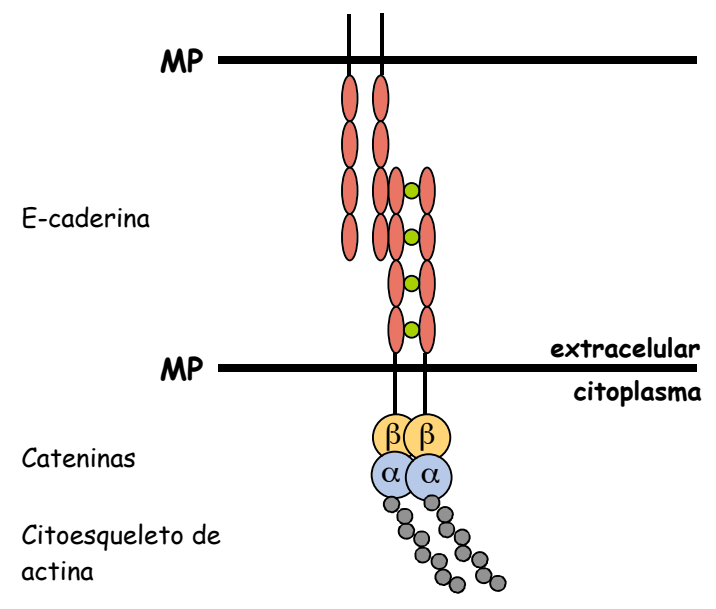

Figura 12: Esquema de las uniones entre la $E$ caderina y las cateninas. La E-caderina es una glicoproteína transmembrana de $120 \mathrm{kDa}$ implicada en la adhesión celular de los epitelios. En su dominio extracelular el enlace célula a célula se produce por interacciones homofílicas reguladas por calcio, mientras que en el dominio intracelular se une al citoesqueleto de actina por medio de las cateninas. De esta manera estabiliza las uniones adherentes. MP=membrana plasmática.

Como podemos observar en la Figura 13, sólo el clon 18 de las MDCK tranfectadas con Snai3 muestra el perfil de expresión de células epiteliales transformadas en mesenquimales, en que podemos ver el descenso en la expresión proteica de E-caderina, $\beta$-catenina y $\gamma$-catenina, y también el aumento en la expresión de Vimentina cuando se compara con la expresión de las mismas proteínas en las células Mock y en los otros clones de MDCK transfectadas con Snai3. Esto coincide con el cambio en el fenotipo celular que hemos observado anteriormente en este mismo clon.

Aunque en ninguno de los otros clones de MDCK transfectadas con Snai3 podemos observar un cambio en la expresión de los marcadores epiteliales y 
mesenquimales similar al observado en el clon 18, se observan disminuciones más pequeñas en la expresión de marcadores epiteliales en algunos clones, como son el clon 16 y 21. Estos clones muestran un menor nivel de expresión de E-caderina, $\gamma$-catenina y $\beta$-catenina cuando se compara con la expresión de estas proteínas en las células Mock. Pero por otro lado, estos dos clones no muestran un aumento en la expresión de Vimentina.

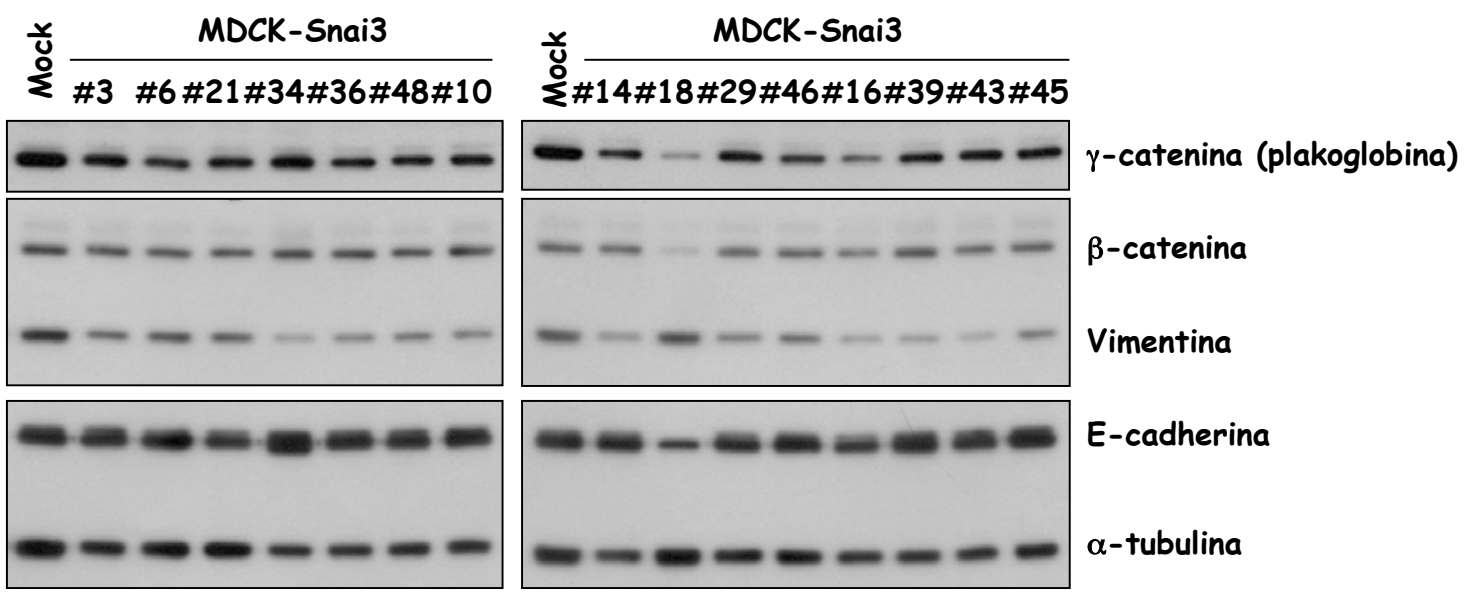

Figura 13: Análisis de expresión de marcadores epiteliales y mesenquimales en los clones de las MDCK transfectadas con Snai3. Analizamos la expresión proteica de $E$-caderina, $\beta$-catenina, $\gamma$ catenina, como marcadores epiteliales, y la expresión de Vimentina como proteína mesenquimal en los clones de las MDCK transfectadas con Snai3 mediante Western Blot. Como control de carga utilizamos $\alpha$-tubulina.

Así pues, estos resultados indican que Snai3 no parece ser capaz de llevar a cabo una transición epitelia mesenquimal.

El siguiente paso fue extraer RNA total de todos los clones de MDCK transfectadas con Snai3 para comprobar que expresan Snai3. Como podemos observar en la Figura 14, donde analizamos la expresión de Snai3 a nivel de RNA mediante Northern Blot, sólo se ve una banda en uno de los clones de las células MDCK transfectadas con Snai3 (Snai3\#14). Debido a que la carga no se ve igual en todas las muestras y además es muy baja en algunos clones, no podemos valorar bien en qué clones se expresa Snai3. Por ello, hicimos cDNA de las muestras para analizar la expresión de Snai3 mediante RT-PCR. 
MDCK-Snai3

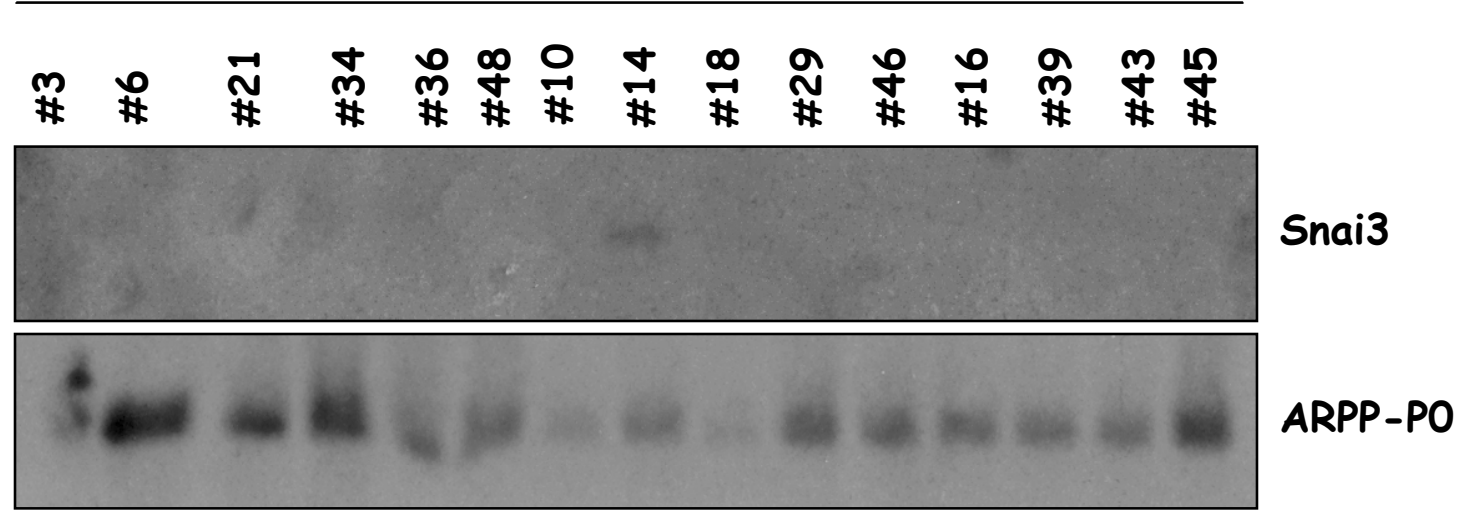

Figura 14: Comprobación de la transfección de las MDCK con Snai3 mediante Northern Blot. Analizamos la eficiencia de la transfección de las MDCK con Snai3 de todos los clones obtenidos mediante Northern Blot con una sonda frente a Snai3. Como control de carga utilizamos ARPP-PO.

Como se puede ver en la Figura 15A, se detecta la expresión de Snai3 en los clones $3,14,21,34,36,29,16$ y 45 .

A

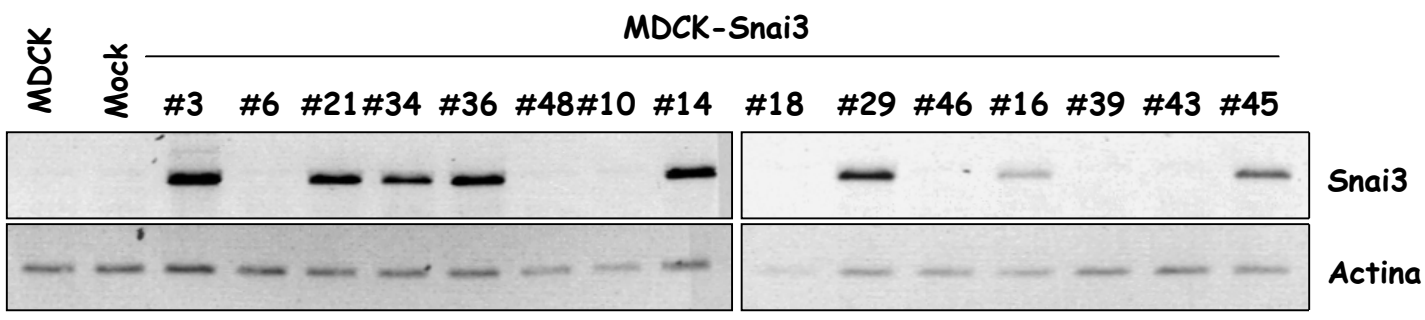

B

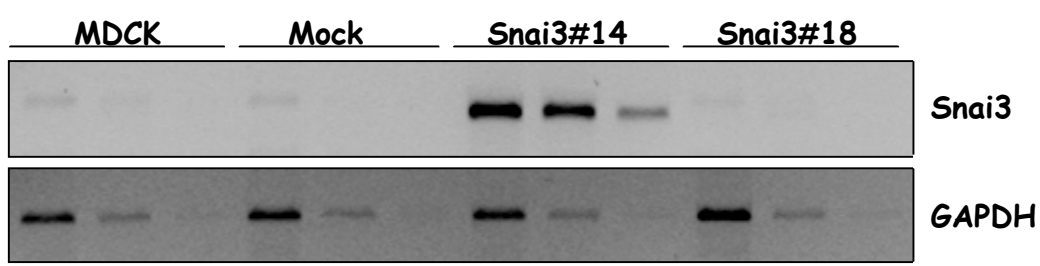

Figura 15: Análisis de la expresión de Snai3 en los clones obtenidos de MDCK transfectadas con Snai3 mediante RT-PCR. (A) Comprobamos la eficiencia de la expresión de Snai3 en todos los clones obtenidos de MDCK transfectadas con Snai3 mediante RT-PCR. Como control analizamos también la expresión de Snai3 en las MDCK sin transfectar y las MDCK transfectadas con el vector vacío (Mock). Como control de carga utilizamos la actina. (B) Análisis de la expresión de Snai3 en las células MDCK sin tranfectar, en las MDCK Mock y en los clones 14 y 18 de las MDCK transfectadas con Snai3 mediante RT-PCR semicuantitativa haciendo diluciones $1 / 5$ y $1 / 25$ a partir del CDNA sin diluir. Como control de carga utilizamos GAPDH. 
Sin embargo, en el único clon (clon\#18) de las MDCK transfectadas con Snai3 en el que hemos observado todas las características propias de un fenotipo mesenquimal, no podemos observar expresión de Snai3 (Figura 15A). Puesto que la carga es muy baja en esta muestra del cDNA, repetimos el análisis de expresión de Snai3, y esta vez analizamos la expresión de Snai3 mediante RT-PCR semicuantitativa para valorar con más rigor las diferencias en la expresión de Snai3 entre las MDCK sin transfectar, las MDCK Mock y el clon 14 de las MDCK transfectadas con Snai3. Pusimos como control positivo el clon 14, ya que ha sido uno de los clones con mayor nivel de expresión de Snai3. Como podemos ver en la Figura 15B, tampoco en esta ocasión observamos expresión de Snai3 en el clon 18. Así pues, parece que la adquisición de propiedades mesenquimales observado en este clon puede ser debida a una transformación espontánea.

Como hemos comentado anteriormente, los miembros Snai1 y Snai2 de la familia Snail son factores de transcripción implicados en el disparo de la EMT (Batlle et al., 2000; Bolos et al., 2003), como hemos observado previamente en el caso del fenotipo de las MDCK transfectadas con Snai1 y Snai2 (Figura 11). Por ello, comparamos la expresión de los marcadores epiteliales y mesenquimales de algunos clones de las MDCK transfectadas con Snai3 con los clones de MDCK transfectadas con Snai1 o Snai2.

En la Figura 16 podemos observar de nuevo que el clon 18 de las MDCK transfectadas con Snai3 (que no expresa Snai3) es el único clon que muestra el perfil de expresión esperado como consecuencia de un proceso de EMT. Este fenómeno no lo podemos observar en los otros 4 clones de las MDCK transfectadas con Snai3 que muestran el mismo perfil en la expresión de los marcadores epiteliales y mesenquimales que los controles negativos, las MDCK y las MDCK transfectadas con el vector vacío (Mock). Los clones de las MDCK transfectadas con Snai1 o Snai2, sí muestran el perfil de expresión esperado, con la disminución de E-caderina, $\beta$-catenina y $\gamma$-catenina y el aumento de Vimentina. Esto coincide con el cambio en el fenotipo celular observado en la Figura 11. 

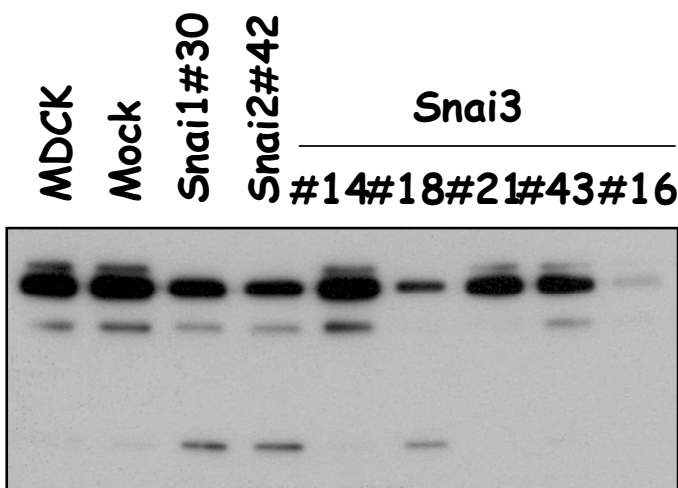

E-caderina

$\beta$-catenina

Vimentina

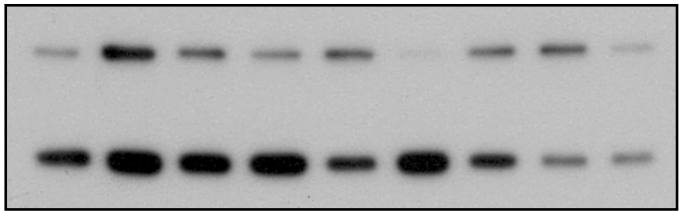

$\gamma$-catenina (plakoglobina)

$\alpha$-tubulina

Figura 16: Comparación de la expresión proteica de marcadores epiteliales y mesenquimales entre los miembros Sani1, Snai2 y Snai3 de la familia Snail. Analizamos mediante Western Blot la expresión proteica de E-caderina, $\beta$-catenina y $\gamma$-catenina, como marcadores epiteliales, y la expresión de Vimentina como proteína mesenquimal en las MDCK, las MDCK transfectadas con el vector vacío, los clones de las MDCK transfectadas con Snai3 y, como control, las MDCK transfectadas con Snai1 o Snai2. Como control de carga utilizamos $\alpha$-tubulina.

En resumen, podemos concluir que Snai3, al contrario que los otros miembros de la familia Snail, Snai1 y Snai2, no va a disparar la EMT, puesto que las células MDCK que expresan Snai3 no muestran las características típicas de la EMT que incluyen el cambio en el fenotipo celular epitelial hacia una forma celular mesenquimal como con consecuencia del aumento en la expresión de marcadores mesenquimales y la disminución en la expresión de marcadores epiteliales.

\section{Función de Snai3 en la supervivencia celular}

Como hemos explicado anteriormente, Snai3 fue considerado un miembro de la familia Snail debido a su homología con Snai1 y Snai2 y por el uso de las secuencias E-box en su unión al DNA. Por ello, como hemos comentado también, no es ilógico pensar que Snai3 podría ejercer su función biológica en procesos similares a aquellos en los que participan Snai1 y Snai2. Uno de estos procesos es la inducción de la EMT, en la que Snai3 no parece estar implicado. Así pues, quisimos estudiar la función de Snai3 en otros procesos de la biología celular en los que están implicados los otros miembros de la familia, Snai1 y Snai2. 


\subsection{La retirada de IL-3 induce la expresión de Snai3}

Como hemos comentado anteriormente, Snai1 y Snai2 están implicados en la supervivencia celular, ya que ambos factores de transcripción protegen a las células de la muerte celular por apoptosis en diferentes contextos celulares (Inoue et al., 2002; Inukai et al., 1999; Kajita et al., 2004; Martinez-Alvarez et al., 2004; Perez-Losada et al., 2003; Perez-Mancera et al., 2006; Perez-Mancera et al., 2005a; Perez-Mancera et al., 2005b; Vega et al., 2004; Wu et al., 2005). La función de Snai2 en supervivencia celular se vio por primera vez en una línea celular pro-B de ratón, $\mathrm{Ba} / \mathrm{F} 3$, dependiente de la citoquina IL-3 para su crecimiento en cultivo. En estas células se vio que la retirada de esta citosina del medio de cultivo llevaba al suicidio celular por apoptosis. Sin embargo, la expresión de Snai2 en esas células, les permitía sobrevivir tras la retirada de la IL-3 (Inukai et al., 1999).

Por ello, quisimos estudiar la función de Snai3 en supervivencia, en el mismo contexto celular descrito anteriormente en el caso de Snai2. Utilizamos como sistema celular la línea hematopoyética Ba/F3, a la que retiramos la citoquina IL-3 del medio de cultivo, para así inducir el proceso de apoptosis.

Como se observa en la Figura 17A, se produce un aumento del porcentaje de células apoptóticas tras la retirada de la IL-3 durante 24 horas, pasando de un $12 \%$ a un 90\%. Quisimos ver a continuación el nivel de expresión de Snai3 en este contexto. Para ello, quitamos la citoquina IL-3 del medio de cultivo de las células $\mathrm{Ba} / \mathrm{F} 3$ y realizamos un time-course recogiendo las células a diferentes tiempos $(0,3,5,8,12$ y 24 horas) tras de la retirada de la IL-3 del medio de cultivo. Analizamos la expresión de Snai3 a nivel de RNA mediante RT-PCR y pudimos ver que la expresión de Snai3 aumenta a medida que aumenta el tiempo de la retirada de la IL-3 (Figura 17B). 
A

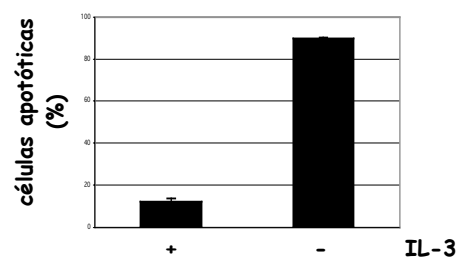

B

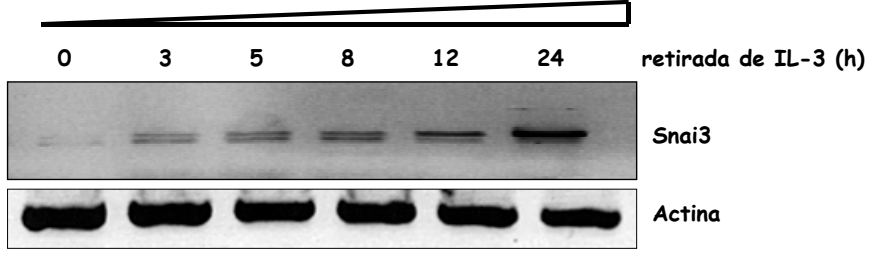

Figura 17: La retirada de la IL-3 induce un aumento de la expresión de Snai3 en células $\mathrm{Ba} / \mathrm{F3}$. A: Estudio de apoptosis con células $\mathrm{Ba} / \mathrm{F3}$ cultivadas en ausencia o presencia de IL-3. El porcentaje de células apoptóticas aumenta tras la retirada de la IL-3 (24 horas) del medio de cultivo de las células $\mathrm{Ba} / \mathrm{F3}$. B: Análisis de la expresión de Snai3 por RT-PCR en células $\mathrm{Ba} / \mathrm{F} 3$ a las que se ha retirado la IL-3 del medio de cultivo. Las células fueron recogidas a diferentes tiempos $(0,3,5,8,12$ y 24 horas) y se puede ver que la expresión de Snai3 aumenta a medida que aumenta el tiempo sin IL3. La actina fue utilizada como control de carga.

Este resultado nos indica una posible implicación de Snai3 en el proceso de apoptosis, el cual parece ser opuesto al papel desempeñado por los otros miembros de la familia, Snai1 y Snai2, ya que ambos actúan favoreciendo la supervivencia. De la misma manera que observamos en el proceso de EMT, en esta ocasión Snai3 tampoco actúa de la misma manera que los otros dos miembros de la familia, Snai1 y Snai2. Por otro lado, esto podría coincidir con el hecho que Snai3 ocupa una posición inusual en el árbol filogenético de las proteínas de la familia Snail de vertebrados y, por tanto, podría actuar de una forma diferente.

\section{Regulación de la expresión de Snai3 en respuesta al daño en el DNA}

\subsection{La expresión de Snai3 está regulada tras daño en el DNA}

El resultado obtenido en el sistema celular Ba/F3 nos indica una posible función de Snai3 en el proceso celular de apoptosis. La inducción de la muerte celular programada mediante la retirada de la citoquina IL-3 sólo es una de las formas de inducir apoptosis. Este proceso de apoptosis puede ser inducido por diferentes tipos de estrés en función del contexto celular, como hemos explicado anteriormente. Otro tipo de estrés celular se produce por daño en el DNA.

Los miembros de la familia Snail, Snai1 y Snai2, están implicados en la vía de transducción de señales que se inducen tras daño en el DNA, como ha sido observado por otros grupos (Kajita et al., 2004; Vega et al., 2004; Wu et al., 2005) y en nuestro laboratorio (Perez-Mancera et al., 2005b) (los datos de Snai2 aún no publicados). 
Para saber si Snai3 también está regulado en esta vía que se induce tras daño en el DNA, nosotros nos propusimos estudiar la expresión de Snai3 tras daño en el DNA. Para determinar mediante estudios in vitro si Snai3 tiene un papel funcional en la respuesta al daño en el DNA utilizamos como modelo celular fibroblastos embrionarios de ratón (MEFs).

Para inducir daño en el DNA utilizamos doxorrubicina, un agente citotóxico que se intercala en el DNA, induce la formación de radicales libres e inhibe a la topoisomerasa II (Liu, 1989; Stewart and Ratain, 1997). El daño en el DNA lo induce al provocar roturas en la doble cadena de DNA.

Tratamos células MEFs control durante 12 ó 24 horas con doxorrubicina y analizamos la expresión de Snai3, tanto por Northern Blot (Figura 18A) como por RTPCR semicuantitativa (Figura 18B). La expresión transcripcional mediante RT-PCR semicuantitativa la analizamos haciendo diluciones $1 / 5$ y 1/25 a partir del cDNA sin diluir. Como se puede ver en las Figuras $18 \mathrm{~A}$ y $18 \mathrm{~B}$, el daño en el DNA induce la expresión de Snai3.

También analizamos la expresión de Snai3 mediante Western Blot (Figura 18C), pero no fuimos capaces de detectar el nivel proteico de Snai3 (aunque no podemos descartar que el anticuerpo comercial utilizado nos impide detectarlo). Como control positivo de la inducción del daño pusimos el anticuerpo contra p53, un gen cuya expresión se induce tras diferentes tipos de daño en el DNA, como hemos explicado anteriormente.

En base a los resultados obtenidos, podemos decir que Snai3 se induce tras daño en el DNA, y por tanto, su regulación es opuesta a la de los otros miembros de la familia, Snai1 y Snai2, cuya expresión transcripcional muestra un descenso tras el daño en el DNA provocado por el tratamiento con doxorrubicina (Perez-Mancera et al., 2005b) (datos de Snai2 aún no publicados). 
A

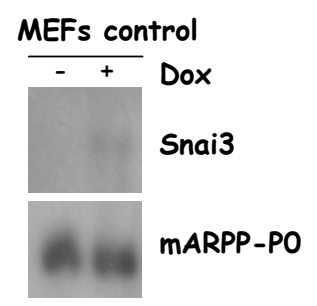

c
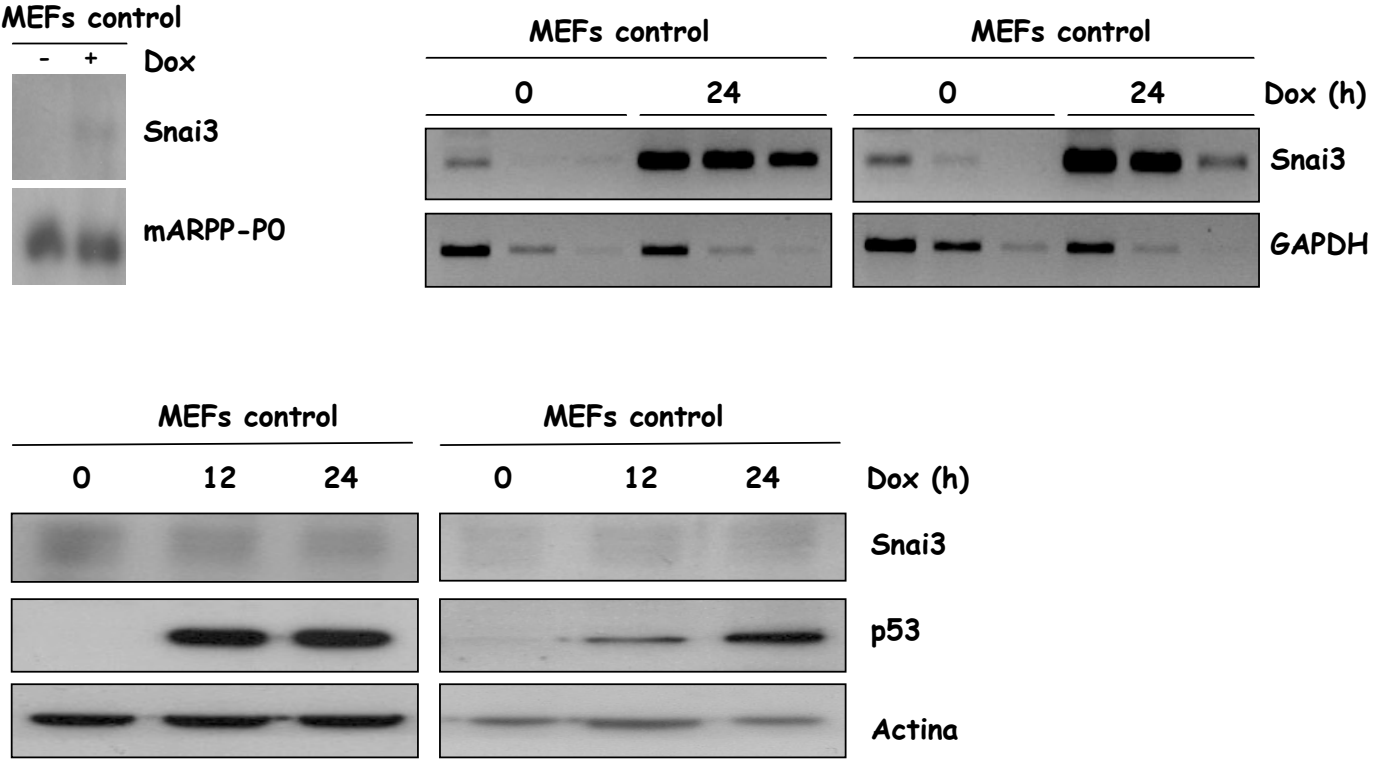

Actina

Figura 18: La expresión de Snai3 está regulada tras daño en el DNA. Análisis de la expresión de Snai3 tras daño en el DNA en células MEFs control. A: Expresión de Snai3 tras 12 horas de tratamiento con doxorrubicina (Dox 0,2 $\mathrm{g} / \mathrm{ml}$ ) mediante Northern Blot. B: Expresión de Snai3 tras tratar las células 12 y 24 horas con doxorrubicina mediante RT-PCR semicuantitativa de CDNA sin diluir, y CDNAs diluidos $1 / 5$ y $1 / 25$ (representada por duplicado). $C$ : Expresión de Snai3 mediante Western Blot. El daño en el DNA fue inducido con doxorrubicina durante 12 y 24 horas (representada por duplicado). La expresión de p53 es el control positivo de la inducción del daño. mARPP-PO (A), GAPDH (B) y actina $(C)$ fueron utilizados como controles de carga.

\subsection{La inhibición del proteasoma no aumenta la cantidad de proteína de Snai3 tras el}

\section{daño en el DNA provocado por doxorrubicina}

Como hemos visto en el experimento anterior, no hemos sido capaces de detectar la proteína Snai3 mediante Western Blot. Esto podría ser debido a que el nivel de Snai3 sea muy bajo y no se pueda detectar, a que la proteína sea degradada rápidamente o a que el anticuerpo contra Snai3 no funcione.

Para descartar la posibilidad de que la proteína sea degradada rápidamente tratamos células MEFs control con el inhibidor del proteasoma MG132 durante 1, 3, 6 y 12 horas (Figura 19). Como hemos mostrado anteriormente, la expresión de Snai3 aumenta tras el tratamiento con doxorrubicina. Por eso, tratamos también MEFs control con doxorrubicina o con MG132 y doxorrubicina juntos. Puesto que la doxorrubicina aumenta la expresión de Snai3 y el inhibidor del proteasoma MG132 inhibe la degradación proteica, el tratamiento con doxorrubicina será nuestro control de la 
inducción del daño, y el tratamiento con el inhibidor del proteasoma y con la doxorrubicina juntos nos indicará si Snai3 es degradado por el proteasoma.

En la Figura 19 podemos ver que nuestros controles de expresión del daño al DNA nos muestran la expresión que esperábamos: p53 aumenta con daño y se detecta un nivel basal más alto de p53 con MG132 al comparar con el control sin tratamiento; p21, un gen implicado también en la vía de transducción de señales tras daño en el DNA (el-Deiry et al., 1993), también aumenta su expresión; y la expresión de Snai2 disminuye con el daño como sería de esperar. Todos esos efectos se ven mejor en los tiempos más largos, como son 6 y 12 horas de tratamiento con doxorrubicina. En cuanto al uso del inhibidor del proteasoma MG132, no nos permite detectar el nivel proteico de Snai3 por Western Blot, como tampoco en la muestra de las células tratadas con doxorrubicina y MG132 juntos. En cuanto a p53 sólo se detecta a tiempos cortos, como es a 1 y a 3 horas después del tratamiento con MG132 y doxorrubicina, lo cual podría ser debido a la inducción rápida de apoptosis, ya que muchas más proteínas implicadas en este proceso podrían estar activadas sin degradarse como consecuencia de dicho tratamiento.

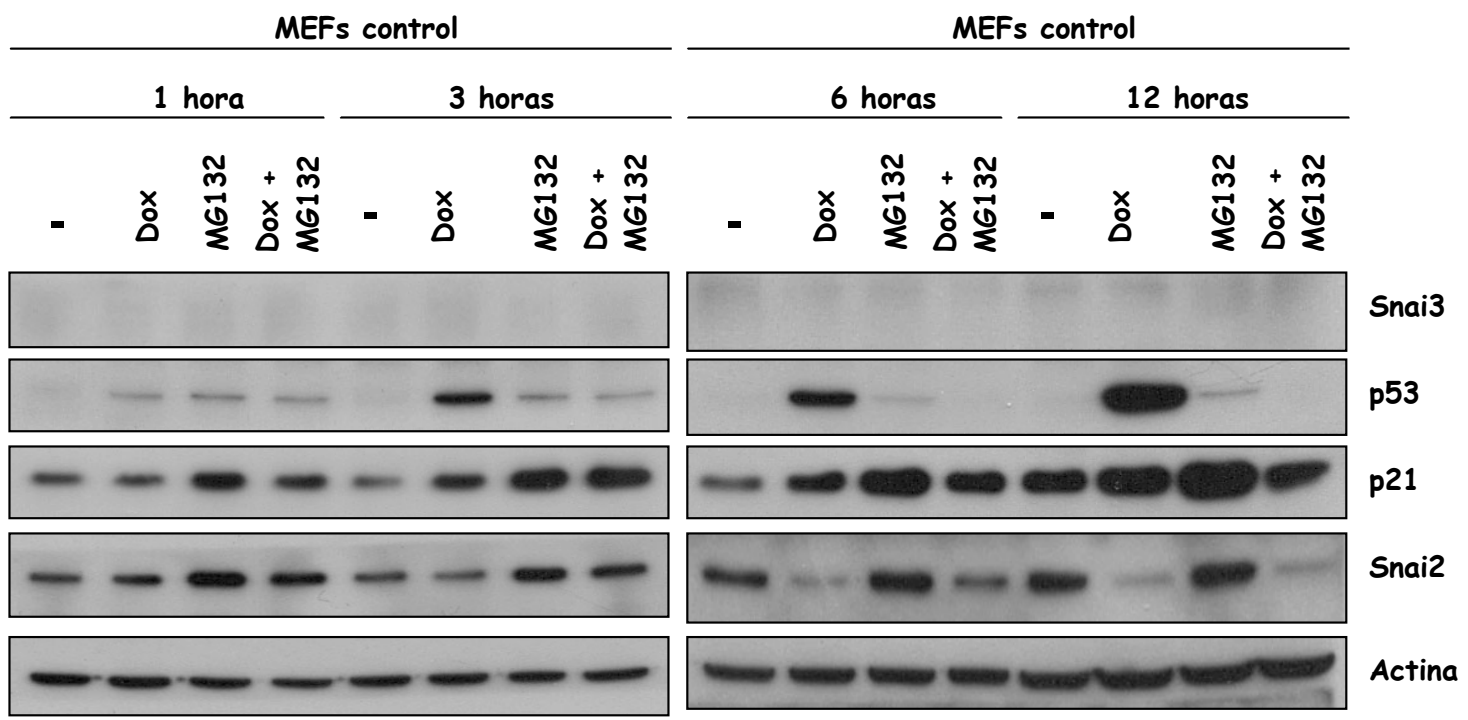

Figura 19: El inhibidor de proteasoma $M G 132$ no aumenta la cantidad de proteína de Snai3 tras daño en el DNA. Células MEFs control fueron tratadas durante $1,3,6$ y 12 horas sin nada, con doxorrubicina $(0,2 \mu \mathrm{g} / \mathrm{ml}), M G 132$ disuelto en DMSO $(10 \mu \mathrm{M})$ o con doxorrubicina y MG132 juntos. Al medio de las células sin MG132 se le añadó la misma cantidad de DMSO que a las células con MG132. Las células fueron analizadas mediante Western Blot utilizando los anticuerpos frente a Snai3, p53, p21, Snai2 y actina. La actina fue utilizada como control de carga. 
Por lo tanto, la degradación rápida de Snai3 no parece ser la causa por la cual no detectamos niveles endógenos de la proteína de Snai3 en las células MEFs control.

\subsection{La expresión de Snai3 se regula de una manera dependiente de p53 tras daño en el DNA}

Como acabamos de ver, Snai3 aumenta tras el daño en el DNA inducido por el tratamiento con doxorrubicina. Uno de los genes más estudiado e importante en la vía de transducción de señales tras daño en el DNA es p53 (Levine, 1997; Levine et al., 1991; Prives and Hall, 1999; Vousden and Lu, 2002), como hemos explicado en detalle anteriormente.

También se sabe que los miembros de la familia Snail, Snai1 y Snai2, están implicados en la vía que se induce tras daño en el DNA (Inoue et al., 2002; Vega et al., 2004; Wu et al., 2005), aunque su regulación es diferente. Así, la regulación de la expresión de Snai1 es independiente de p53, ya que la expresión disminuye tanto en células MEFs control como en células MEFs p53 ${ }^{-/}$tras daño en el DNA (Perez-Mancera et al., 2005b). Por el contrario, la expresión de Snai2 está regulada de manera dependiente de p53, de manera que en los MEFs control disminuye la expresión de Snai2 tras el daño en el DNA provocado por el tratamiento con doxorrubicina, pero en los MEFs $553^{-/-}$la expresión de Snai2, tanto en ausencia como en presencia de daño en el DNA, se mantiene al mismo nivel igual que en los MEFs control sin daño.

Para estudiar si Snai3 también podría estar regulado por la vía de p53, tratamos MEFs de diferentes genotipos, control y $\mathrm{p} 53^{-/-}$, durante 12 horas con doxorrubicina. El uso de los MEFs $553^{-/-}$nos va a permitir estar seguros de que la expresión depende de p53 en el caso de que haya diferencias en la expresión de Snai3 entre los MEFs control y los MEFs $\mathrm{p}^{-3^{--}}$tras daño en el DNA.

Como podemos ver en la Figura 20A, la expresión de Snai3 analizada mediante Northern Blot, sólo se induce en MEFs control tras daño en el DNA, puesto que no se detecta la expresión de Snai3 en células MEFs p53 $3^{-{ }^{-}}$. La expresión de p21 nos sirvió como control positivo para comprobar la inducción del daño dependiente de p53, ya que p21 ha sido descrito como una diana directa de p53 en la vía de transducción de señales tras daño en el DNA (el-Deiry et al., 1993). En la Figura 20B se ven más en detalle las diferencias en la expresión de Snai3, que se induce de una manera dependiente de p53. Esta figura nos muestra el nivel de expresión de Snai3 tras el tratamiento con 
doxorrubicina durante 0,12 y 24 horas en MEFs control y MEFs $\mathrm{p}^{-/-}$mediante RTPCR semicuantitativa en la que hicimos diluciones $1 / 5$ y $1 / 25$ a partir del cDNA. A pesar de que la expresión transcripcional también aumenta en células MEFs p $53^{-/-}$tras daño en el DNA, el aumento de la expresión de Snai3 no es igual que en los MEFs control, donde el nivel de expresión de Snai3 es del doble o más con respecto al de los MEFs p53 $3^{-/-}$.

A
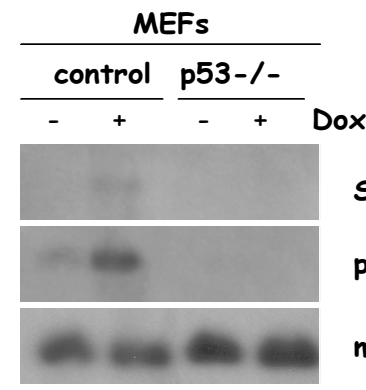

Snai3

p21

mARPP-PO
B

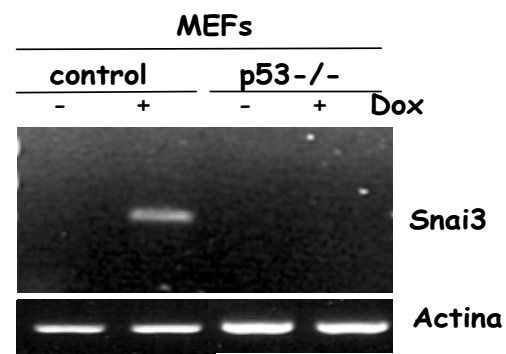

C

MEFs
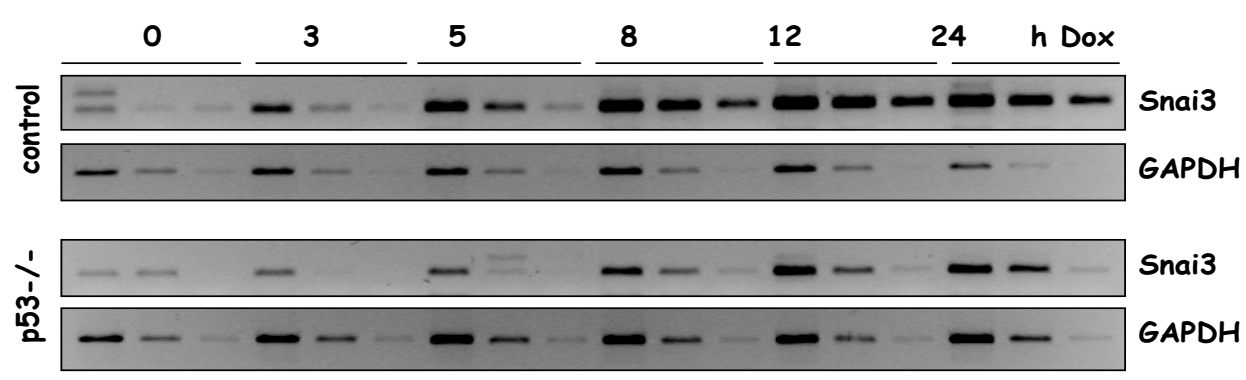

$D$
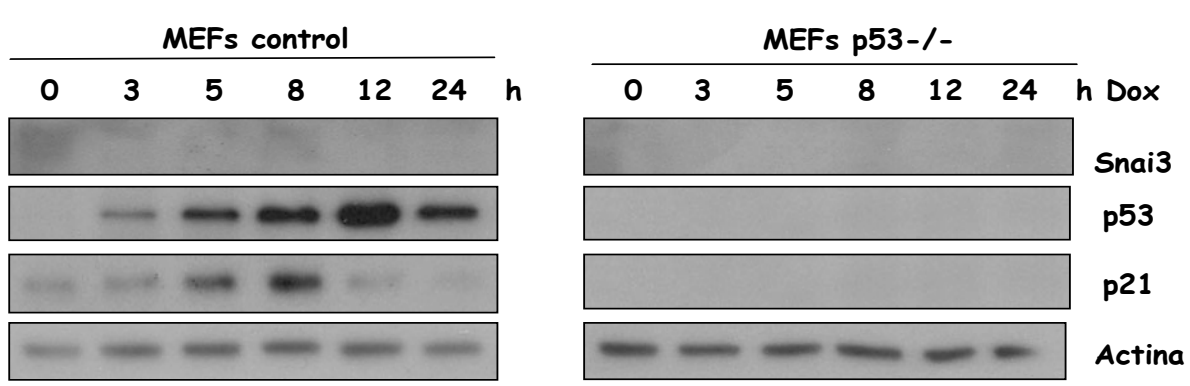

Figura 20: La regulación de la expresión de Snai3 tras daño en el DNA es dependiente de p53. Expresión de Snai3 en células MEFs control y MEFs $p 53^{-1-}$. A: Análisis de la expresión de Snai3 mediante Northern Blot. p21, una diana de p53, fue utilizado como control del daño, y mARPP-PO como control de carga. B: Análisis de la expresión de Snai3 mediante RT-PCR semicuantitativa de CDNAS sin diluir, diluidos $1 / 5$ y $1 / 25$. Como control de carga utilizamos GAPDH. C: Estudio de la regulación de la expresión de Snai3 en células MEFs control mediante un time-course de 0, 3, 5, 8, 12 y 24 horas de tratamiento con doxorrubicina. El nivel de expresión de Snai3 fue analizado mediante RT-PCR semicuantitativa de CDNAs sin diluir, y cDNAs diluidos $1 / 5$ y $1 / 25$. GAPDH fue utilizado como control de carga. D: Análisis de la expresión de Snai3 mediante Western Blot. p53 y p21 fueron utilizados como control de la inducción del daño, y la actina confirma una carga parecida. El daño en el DNA fue inducido en todos los estudios con doxorrubicina $(0,2 \mu \mathrm{g} / \mathrm{ml})$ durante los tiempos indicados. 
Snai3, por tanto, va a estar regulado tras daño en el DNA de una manera dependiente de p53, de manera que cuando se produce daño y aumenta el nivel de p53, se va a producir un aumento en el nivel de expresión de Snai3, al menos a nivel de RNA.

Quisimos ver a continuación, cómo se regula la expresión de Snai3 en el tiempo, y por ello hicimos un experimento en el cual recogimos las células MEFs control tratadas con doxorrubicina a diferentes tiempos $(0,3,5,8,12$ y 24 horas) y analizamos la expresión transcripcional mediante RT-PCR semicuantitativa (Figura 20C). Vimos que la expresión de Snai3 empieza a aumentar a partir de las 3 horas hasta las 8 horas, tiempo a partir de la cual se mantiene el nivel de expresión de Snai3 hasta las 24 horas. De este mismo time-course cogimos también una parte de las células para ver el nivel proteico de Snai3 tras daño en el DNA, pero como ya hemos comentado y como se ve en la Figura 20D, la proteína Snai3 no se detecta, ni en los MEFs control ni en los MEFs p53 ${ }^{-/}$.

Lo que sí se puede observar es que la expresión de p53 aumenta a partir de las 3 horas después del tratamiento con doxorrubicina, el mismo momento en que empieza también el aumento en la expresión de Snai3, observado mediante RT-PCR semicuantitativa (Figura 20C).

Podemos decir por tanto, que Snai3, al igual que Snai2, está regulado de manera dependiente de p53 tras daño en el DNA, aunque de forma opuesta. Así, mientras que Snai2 va a ser reprimido tras daño en el DNA, Snai3 va a ser inducido.

\subsection{El promotor de Snai3 se induce tras daño en el DNA de una manera dependiente de p53}

Para confirmar si Snai3 es una diana transcripcional en la vía de p53, de manera que p53 regula positivamente su expresión, clonamos aproximadamente 2783 pares de bases (pb) del promotor de Snai3 de ratón en el vector pGL3-basic. En este vector el promotor de Snai3 va a ir clonado delante de un gen reporter de Luciferasa, de manera que la activación del promotor se traduce en expresión del gen Luciferasa. La medida de la cantidad de luminiscencia emitida por la Luciferasa nos va a indicar si el promotor de interés está inducido o reprimido en determinadas situaciones celulares.

Para realizar el estudio utilizamos dos líneas celulares, U2OS y SaoS-2, que son líneas celulares humanas de osteosarcoma. Las células U2OS expresan la forma 
silvestre de p53 (Florenes et al., 1994) y las células Saos-2 no expresan p53 (Chandar et al., 1992). Estas células fueron transfectadas con la construcción con el promotor de Snai3 o con el vector vacío, y con un control de normalización (pRL-SV40). Una vez transfectadas las células, las tratamos con doxorrubicina para inducir p53 y ver si así se activa el promotor de Snai3 (Figura 21).

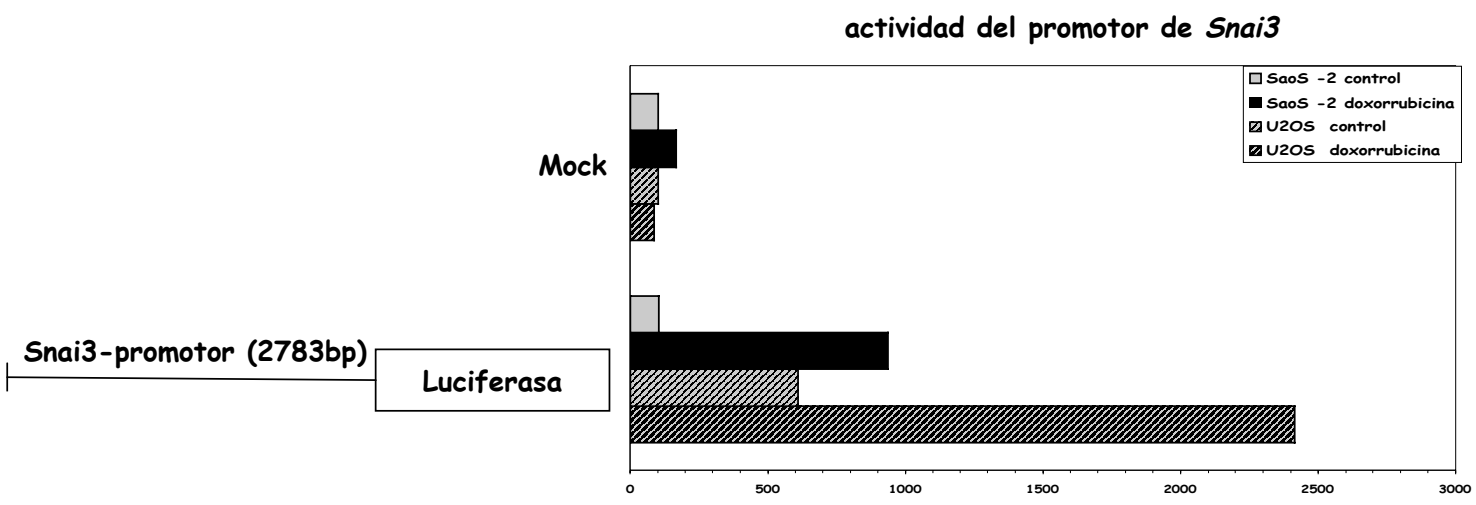

Figura 21: Identificación de Snai3 como un gen regulado de manera dependiente de p53. Las células U2OS y SaoS-2 fueron transfectadas con el vector pGL3-basic que contiene la secuencia del promotor de Snai3 (2783 bp) clonado delante del gen reporter Luciferasa (5 $\mu \mathrm{g})$. 24 horas después de la transfección, las células fueron tratadas con doxorrubicina $(0,2 \mu \mathrm{g} / \mathrm{ml})$. La actividad del promotor fue medida 24 horas después del tratamiento con doxorrubicina mediante el ensayo de luciferasa. Tras el tratamiento con doxorrubicina se observa un incremento evidente en la actividad del promotor de Snai3 en las células U2OS. Para la normalización de los resultados se utilizó el vector pRL-SV40 (1 $1 \mu \mathrm{g})$.

Como se observa en la Figura 21, tras la transfección con el promotor de Snai3 y el tratamiento con doxorrubicina en las células U2OS (que expresan p53) aumenta la actividad Luciferasa 27,8 veces, cuando se compara con la actividad Luciferasa en las células también tratadas con doxorrubicina pero transfectadas con el vector vacío. Por el contrario, la falta de expresión de p53 en las células SaoS-2 transfectadas con el promotor de Snai3 y tratadas con doxorrubicina, hace que la actividad de Luciferasa sólo se multiplique por 9, cuando se compara con la actividad Luciferasa de las células transfectadas con el vector vacío y tratadas con doxorrubicina. Por tanto, estos resultados son congruentes con la dependencia de p53 en la regulación de Snai3 tras daño en el DNA.

La inducción del promotor de Snai3 en las células SaoS-2 (que no expresan p53) es sólo de aproximadamente una tercera parte de la inducción que hemos observado en las células U2OS, y similar a la actividad Luciferasa observada en las células U2OS 
transfectadas con el promotor de Snai3 pero sin tratar con doxorrubicina. Esta inducción podría coincidir con la inducción de la expresión de Snai3 observada en las células MEFs $\mathrm{p}^{-/-}$tratadas con doxorrubicina (Figura 20C). El hecho de que el promotor de Snai3 también se active ligeramente en ausencia de p53, podría indicar la existencia de otros mecanismos independientes de p53 que regulen la expresión de Snai3 tras daño en el DNA.

\subsection{La activación de Snai3 está mediada específicamente por la vía de p53}

Como acabamos de mostrar, Snai3 está inducido por la vía de p53 tras daño en el DNA provocado por el tratamiento con doxorrubicina. Aunque hemos mostrado la dependencia de p53 en la activación de la expresión de Snai3 utilizando MEFs control y MEFs $\mathrm{p}^{-{ }^{-/}}$y en la activación del promotor en las líneas celulares U2OS y SaoS-2, los agentes citotóxicos, como es la doxorrubicina, también tienen actividades independientes de p53 y pueden afectar a la sensibilidad de células tumorogénicas, como son los MEFs p53 ${ }^{-{ }^{-}}$. Para evitar ese efecto utilizamos las nutlins (Vassilev et al., 2004). Las nutlins son pequeñas moléculas y potentes inhibidoras de la interacción de mdm2 y p53 y tienen, por otro lado, tanto in vitro como in vivo, actividades antitumorogénicas (Vassilev et al., 2004).

Como hemos explicado, en condiciones fisiológicas la expresión de p53 está estrechamente controlada por mdm2 mediante un circuito autorregulado (Ashcroft and Vousden, 1999; Oliner et al., 1993; Picksley and Lane, 1993; Wu et al., 1993). p53 activa la expresión de mdm2, y esto a su vez lleva a la represión de p53 por diferentes mecanismos (Michael and Oren, 2003). Las nutlins son capaces de unirse a mdm2 y, de esta manera, bloquean la unión de mdm2 y p53, activando así la vía de p53, pero esto sólo va a ser así en células que expresan p53 en su forma silvestre y no en su forma mutada (Vassilev et al., 2004).

Utilizamos 2 enantiómeros diferentes: nutlin-3a (el enantiómero activo) y nutlin3 b (el enantiómero con una actividad 150 veces menor que la nutlin-3a y que, por tanto, puede ser considerado como control negativo). Por tanto, para ver si la inducción de Snai3 es debida a la activación de la vía de p53, tratamos células MEFs control con el potente inhibidor de mdm2 nutlin-3a o con el control negativo nutlin-3b. Como se puede ver en la Figura 22, a nivel de RNA, sólo la forma activa (nutlin-3a) induce la expresión de Snai3. Esta inducción de la expresión de Snai3, sin embargo, sólo se 
detecta en las células que están tratadas con una concentración alta $(10 \mu \mathrm{M})$ de nutlin-3a, lo cual podría ser debido a la dificultad de inducir un nivel de Snai3 detectable, como hemos visto en experimentos anteriores.

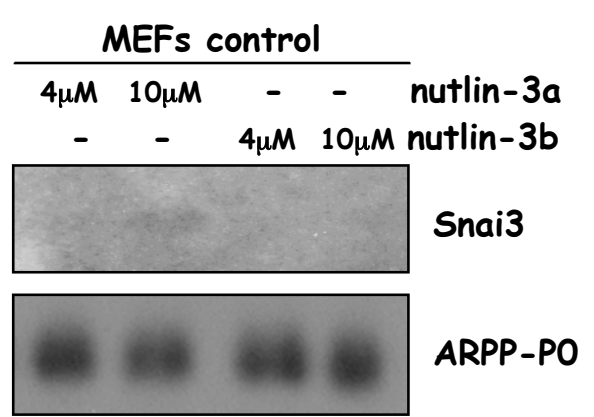

Figura 22: La activación de p53 por las nutlin-3a induce la expresión de Snai3 en los MEFs control. Tratamos células MEFs control con las nutlin-3a $(4 \mu M$ y $10 \mu M)$ o con las nutlin-3b $(4 \mu M$ y $10 \mu M)$ durante 12 horas y analizamos la expresión de Snai3 mediante Northern Blot con una sonda específica frente al fragmento full-lenght de Snai3. ARPP-PO fue utilizado como control de carga.

Por lo tanto, podemos confirmar que la expresión de Snai3 tras daño en el DNA está regulada de una manera dependiente de p53.

\subsection{Snai3 es una diana de p53}

Como acabamos de mostrar, Snai3 está regulado positivamente tras daño en el DNA, puesto que en presencia de daño provocado por el tratamiento con doxorrubicina aumenta el nivel de transcripción de Snai3 (Figura 18A+B). También hemos mostrado, mediante diferentes métodos, que esta regulación está mediada por la vía de p53 (Figuras $20 A+B+C, 21$ y 22). Para determinar si p53 regula la transcripción de Snai3 de forma directa o de forma indirecta, analizamos la secuencia del gen Snai3, tanto de humano como de ratón, para ver si existen secuencias específicas de DNA a las que se puede unir p53 (denominadas responsive elements (RE) de p53) para lo cual utilizamos el programa p53MH algorithm (Hoh et al., 2002).

Como podemos ver en la Figura 23, mediante el uso de este programa encontramos 3 sitios de unión específicos para p53 conservados tanto en humano como en ratón, de los cuales uno se encuentra en el promotor y dos en el intrón 1 del gen Snai3. 
hSNAI3

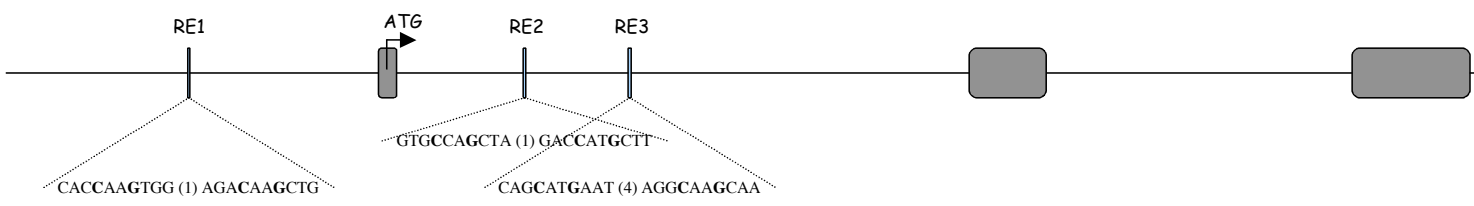

mSnai3

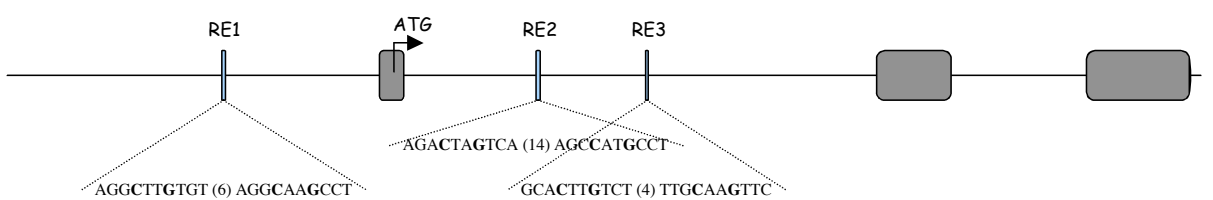

Figura 23: Esquema del gen Snai3 en humano y en ratón. Esquema de la secuencia del gen Snai3 de humano y de ratón, en el que se indican las secuencias de unión de p53 (responsive elements (RE)) que aparecen como RE1, RE2 y RE3. Una de estas secuencias se encuentra en el promotor y las otras dos en el intrón 1. Los exones están representados mediante cajas en gris.

Para determinar si p53 regula de forma directa la transcripción de Snai3 mediante su unión a una de estas secuencias, realizamos ensayo de inmunoprecipitación de cromatina (chromatin immunoprecipitation; ChIP). Para ello, utilizamos células MEFs control cultivadas tanto en ausencia como en presencia de doxorrubicina durante 12 horas. A continuación, fijamos las uniones de las proteínas al DNA con formaldehído. Después aislamos el DNA, junto a las proteínas unidas, y lo fragmentamos mediante sonicación. Posteriormente, utilizando un anticuerpo específico frente a p53 aislamos las moléculas de DNA a las que estaba unida esta proteína. Finalmente, revertimos el entrecruzamiento entre la proteína y el DNA para liberar el DNA, y mediante RT-PCR se amplificaron las secuencias de interés, RE1, RE2, RE3, utilizando oligos específicos generados en torno a dichas secuencias de interés (Figura 24A), y también Hprt como control negativo.

Como podemos ver en la Figura 24B, en las células cultivadas en ausencia de doxorrubicina cuando se inmunoprecipita con el anticuerpo frente a p53 (p53 1, p53 2), no se observa amplificación de la secuencia RE1 situada en el promotor, ni de las secuencias RE2 y RE3 situadas en el intrón 1. Esto era de esperar, puesto que en ausencia de daño en el DNA el nivel de p53 en la célula es bajo, y por ello, la unión de p53 al promotor de Snai3 sería muy escasa. Sin embargo, en la Figura 24C, podemos observar que en presencia de daño provocado por el tratamiento con doxorrubicina en 
los MEFs control, existe amplificación para diferentes RE de p53. Así, en el caso de la muestra p53 1, existe amplificación para el RE1, lo que indicará que p53 se une a la secuencia RE1 localizada en el promotor. En el caso de la muestra p53 2, observamos que existe amplificación para el RE3 y el RE1, lo que indicará que p53 se une a la secuencia RE3 localizada en el intrón 1 y a la secuencia RE1 localizada en el promotor. No observamos amplificación para la secuencia RE2 del intrón 1, lo cual nos indicará que p53 no se une a esta secuencia en el promotor de Snai3.

A

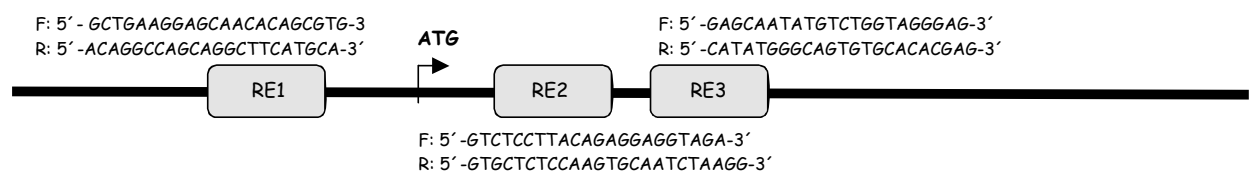

B

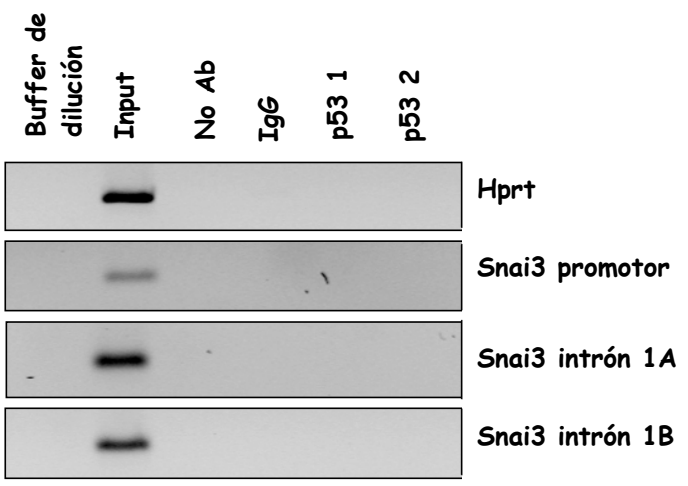

$C$

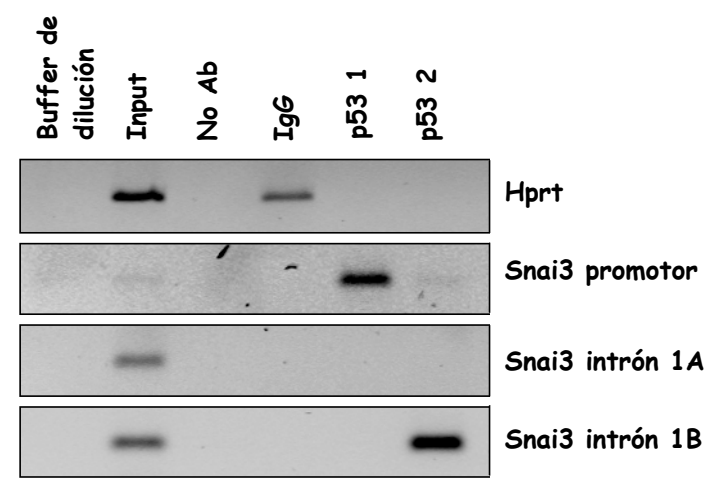

Figura 24: Estudio de la regulación de la transcripción de Snai3 por p53 mediante ChIP. (A) Esquema del gen Snai3 con las 3 secuencias RE encontradas para la unión de p53 y con los oligos utilizados para su amplificación ( $F=$ Forward; $R=$ Reverse).; Analizamos mediante la inmunoprecipitación de la cromatina (ChIP) si p53 regula la transcripción de Snai3 de forma directa o de forma indirecta en células MEFs control cultivadas en ausencia (B) o en presencia $(C)$ de doxorrubicina. Analizamos la unión de p53 a las secuencia RE que se encuentran en el promotor y en el intrón 1 del gen de Snai3 mediante RT-PCR amplificando las secuencias de interés utilizando oligos específicos. Como control negativo utilizamos Hprt. Utilizamos como muestras MEFs control inmunoprecipitados de la siguiente manera: sin anticuerpo (una muestra), con un anticuerpo inespecífico (muestra IgG) o con un anticuerpo específico para p53 (2 muestras: p53 1 y 2). La muestra con Buffer de dilución es el control negativo, ya que no tiene DNA, y la muestra Input es nuestro control positivo puesto que contiene el DNA sin inmunoprecipitar.

Por lo tanto, podemos decir que p53 parece regular la expresión de Snai3 de forma directa, utilizando dos secuencias, RE1 y RE3, situadas en el promotor y en el intrón 1 del gen Snai3, respectivamente. 
En resumen, con los resultados obtenidos hasta ahora, podemos concluir que en células MEFs tras el daño en el DNA provocado por el tratamiento con doxorrubicina Snai3 está regulado de manera directa por p53. Además, esta regulación va a ser positiva, ya que la expresión de Snai3 aumenta a nivel de RNA.

\section{Estudios de sobre-expresión de Snai3}

Para estudiar la función de una proteína en un contexto celular puede ser oportuno utilizar diferentes métodos. Dos de los más usados son la sobre-expresión de la proteína de interés o, por el contrario, la disminución de la expresión haciendo uso de pequeños RNAs de interferencia (siRNA).

En nuestro caso, para el estudio de la función de Snai3 en la biología celular, nos interesó empezar con el método de sobre-expresión. Elegimos este método pensando en poder aumentar la expresión proteica a un nivel detectable por Western Blot, para así poder ver los efectos más relevantes que Snai3 podría producir en los procesos que se activan tras daño en el DNA.

\subsection{Snai3 se localiza en el núcleo}

Como hemos descrito previamente, Snai3 es un factor de transcripción y, por tanto, sería lógico que tuviera localización nuclear, para allí desempeñar su función biológica (Kataoka et al., 2000). Sin embargo, puesto que para otros factores de transcripción se ha descrito que pueden tener localización citoplasmática, quisimos determinar dónde se encuentra Snai3 en la célula.

Para ello, construimos una proteína de fusión GFP-Snai3, de manera que cuando Snai3 se transcriba y se traduzca a proteína, va a sintetizarse unida a la proteína GFP (green fluorescence protein). Puesto que la proteína GFP emite fluorescencia, va a ser visualizada cuando se observa en el microscopio confocal. De esta manera, cuando se detecta señal de fluorescencia debida a GFP, querrá decir que Snai3 está localizado en ese mismo punto, puesto que ambas proteínas forman una proteína de fusión. Por tanto, transfectamos las líneas celulares U2OS y SaoS-2 (descritas anteriormente) con esta proteína de fusión (Figura 25).

El núcleo de las células fue marcado con ioduro de propidio (IP), un agente que se intercala en el DNA y de esta manera nos permite localizar el núcleo en la célula. La superposición de la señal de la proteína GFP y la señal del IP indica claramente que la localización de GFP y por tanto de Snai3 es nuclear. 

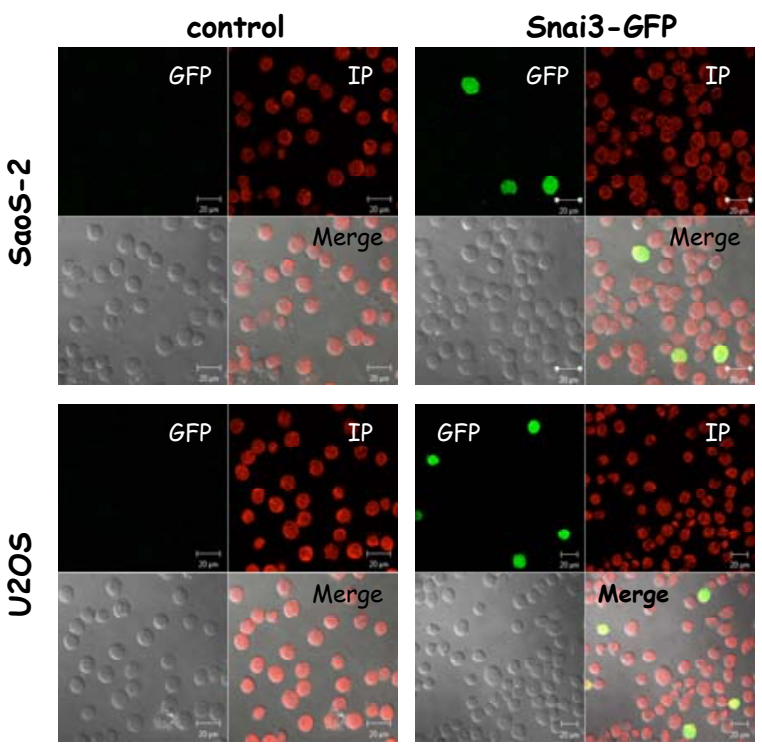

Figura 25: Localización de Snai3 en el núcleo. Transfectamos las líneas celulares humanas de osteosarcoma U2OS y SaoS-2 de forma transitoria con una proteína de fusión GFP-Snai3 (pEGFP-C1-Snai3), y detectamos mediante inmunofluorescencia la expresión de la proteína GFP (control: células sin transfectar) (arriba a la izquierda). El núcleo fue marcado con IP $(0,3 \mu \mathrm{g} / \mathrm{ml})$ (arriba a la derecha) y la forma de las células se observó con luz transmitida (abajo a la izquierda). La localización de la proteína de fusión fue detectada poniendo todas las señales juntas (abajo a la derecha).

\subsection{Participación de Snai3 en las respuestas celulares tras daño en el DNA}

\subsubsection{Apoptosis}

Dentro de las respuestas celulares inducidas por p53 tras daño en el DNA está el proceso de apoptosis, que es un proceso central en la supresión de tumores (Schmitt et al., 2002). En este contexto, se han descrito numerosas dianas transcripcionales de p53 que están envueltas en la apoptosis dependiente de p53 (Vousden and Lu, 2002).

Acabamos de mostrar que Snai3 está regulado tras el daño en el DNA por el tratamiento con doxorrubicina de una manera dependiente de p53. Hemos visto también que la expresión de Snai3 está inducida en las células Ba/F3 tras la retirada de la IL-3, que es una forma de inducir la muerte celular por apoptosis. El aumento en la expresión de Snai3 tanto en el contexto celular de las $\mathrm{Ba} / \mathrm{F} 3$, como en el contexto celular de los MEFs, y el hecho de que la expresión de Snai3 aumente en paralelo a la expresión de p53, nos llevó a estudiar la posible función de Snai3 en el proceso de apoptosis dependiente de p53.

\subsubsection{Expresión de Snai3 en células E1A-MEFs control y E1A-MEFs p53 ${ }^{-/-}$}

Para estudiar la posible función de Snai3 en el proceso de apoptosis dependiente de p53, elegimos, como en experimentos anteriores, el contexto celular de los MEFs, que representa un buen sistema celular para estudiar las respuestas celulares en las que está implicado p53. 
Para sensibilizar a los MEFs para que se induzca el proceso de apoptosis tras el tratamiento con la mayoría de los agentes que dañan el DNA son necesarias señales oncogénicas (Debbas and White, 1993; Lowe and Ruley, 1993). Por ello, con el fin de inducir el proceso de apoptosis en MEFs quisimos infectarlos con E1A, puesto que se ha descrito que los MEFs que expresan la oncoproteína adenoviral E1A tras el tratamiento con un agente que daña el DNA o un agente quimioterapéutico inducen el proceso de apoptosis de manera dependiente de p53, en vez de inducir el arresto del ciclo celular (Lowe et al., 1993a). E1 A promueve el proceso de apoptosis interactuando con los reguladores del ciclo celular (White, 1998), como son por ejemplo la familia de retinoblastoma $(\mathrm{Rb})$ o la proteína p300 (Lavia et al., 2003). La inhibición de p300 por E1A protege la activación transcripcional de mdm2 (Thomas and White, 1998; White, 1998), favoreciendo así la acumulación de p53.

Para saber cómo se comporta Snai3 en los E1A-MEFs tras daño en el DNA, tratamos células E1A-MEFs control y E1A-MEFs p53 ${ }^{-/-}$con doxorrubicina durante 24 horas, y analizamos la expresión de Snai3 a nivel transcripcional mediante RT-PCR semicuantitativa, haciendo diluciones $1 / 5$ y 1/25 a partir del cDNA normal.

Como se puede ver en la Figura 26, se ven las mismas diferencias en la expresión de Snai3 a nivel de RNA en los E1A-MEFs como hemos observado anteriormente en los MEFs sin E1A. Es decir, el nivel de expresión de Snai3 en las células E1A-MEFs control y E1A-MEFs p53 ${ }^{-/}$aumenta tras el daño en el DNA provocado por el tratamiento con doxorrubicina, sin embargo esta inducción de Snai3 es mucho mayor en los E1A-MEFs control que en los E1A-MEFs p53 ${ }^{-/}$. Por tanto, de nuevo observamos una dependencia de p53 en la regulación de la expresión de Snai3 tras daño en el DNA en los E1A-MEFs.

E1A-MEFs control

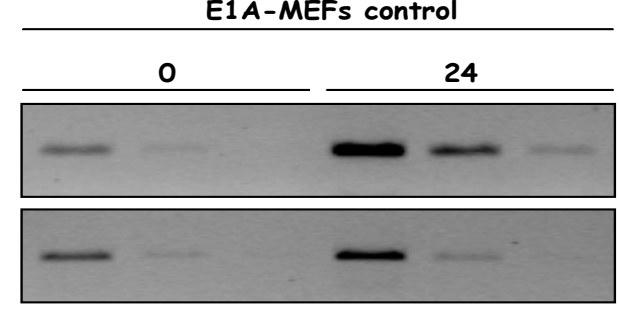

E1A-MEFs p53-1-

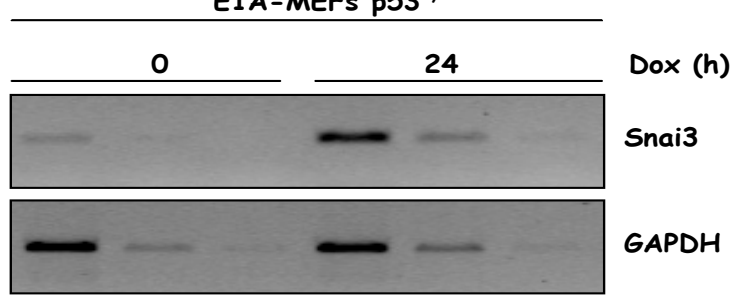

Figura 26: Análisis de la expresión transcripcional de Snai3 en células E1A-MEFs control y E1A-MEFs $p 53^{-/-}$tras el daño en el DNA provocado por el tratamiento con doxorrubicina. La expresión fue analizada mediante RT-PCR semicuantitiva haciendo diluciones $1 / 5$ y $1 / 25$ a partir del CDNA sin diluir. GAPDH fue utilizado como control de carga. 


\subsubsection{La sobre-expresión de Snai3 en MEFs control no induce apoptosis tras} daño en el DNA

Como ya hemos comentado anteriormente, tras la infección de los MEFs con E1A se induce el proceso de apoptosis dependiente de p53 tras daño en el DNA. Puesto que hemos observado que Snai3 aumenta tras daño en el DNA en E1A-MEFs, quisimos estudiar el efecto de la sobre-expresión de Snai3 en células E1A-MEFs control en la respuesta celular de apoptosis tras daño en el DNA.

Para expresar la oncoproteína E1A y sobre-expresar Snai3 infectamos células MEFs control con un alto título de retrovirus producidos mediante la transfección pasajera de células $\phi N X$ (Serrano et al., 1997). Los vectores retrovirales utilizados para transfectar las $\phi$ NX fueron pQCXIP, pQCXIP-mSnai3 y pWLZ Hygro-E1A 12s.

Una vez infectados, tratamos tanto las células E1A-MEFs control infectadas con el retrovirus vacío como las E1A-MEFs control infectadas con Snai3 con doxorrubicina durante 24 horas, y a continuación las analizamos mediante FACS (Figura 27A).

A

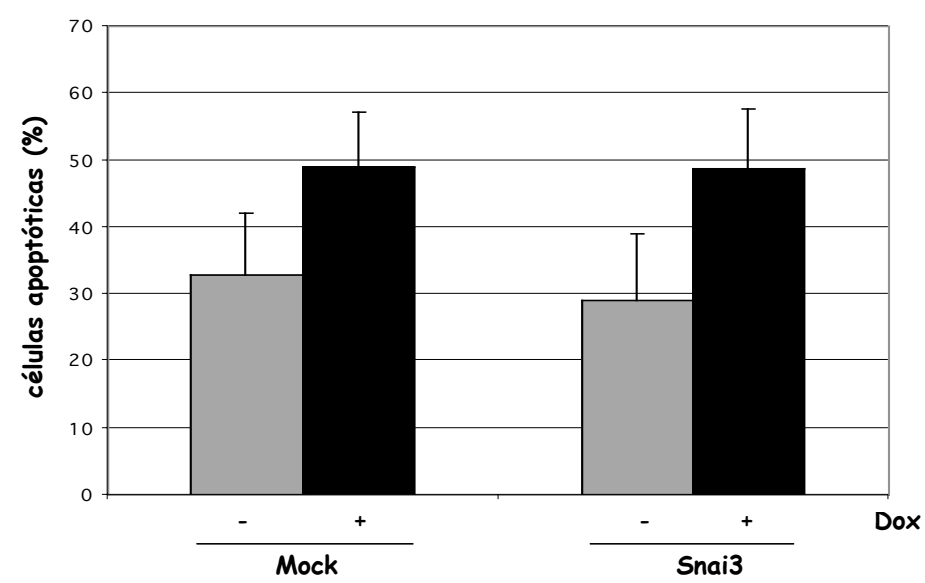

B

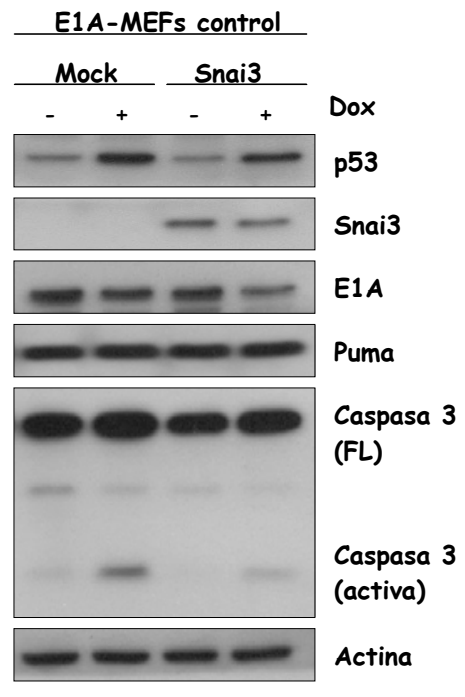

Figura 27: Estudio de la respuesta apoptótica en células E1A-MEFs control que sobre-expresan Snai3. (A) La respuesta apoptótica (porcentaje de células apoptóticas) en células E1A-MEFs control infectadas con el retrovirus vacío (Mock) o con Snai3 tras el tratamiento con doxorrubicina $(0,2 \mu \mathrm{g} / \mathrm{ml})$ durante 24 horas. Las células fueron analizadas mediante FACS marcándolas con Anexina$V$ e IP $(0,5 \mu \mathrm{g} / \mathrm{ml})$ (B) Análisis de la infección (E1A; Snai3), de la inducción de apoptosis (Puma; Caspasa 3) y del daño en el DNA (p53), en los E1A-MEFs control que sobre-expresan Snai3 mediante Western Blot. La actina confirma una carga similar en todas las muestras. 
La Anexina-V se une específicamente a la fosfatidilserina, la cual se encuentra en la cara interna de la membrana plasmática y va a ser expuesta a la cara externa de dicha membrana cuando comienza el proceso de apoptosis, y el Ioduro de propidio se une al DNA de células dañadas y muertas. Por ello, el uso de la Anexina-V y del Ioduro de propidio (IP) nos permite diferenciar entre las células viables (Anexina-V e IP negativos), las células apoptóticas tempranas (Anexina-V positivas e IP negativas) y las apoptóticas tardías (Anexina-V e IP positivas).

Mediante Western Blot confirmamos la eficiencia de la infección y de la respuesta tras daño en el DNA mediante el análisis de la expresión de p53, Snai3 y E1A (Figura 27B), donde se ve que p53 aumenta tras daño, que E1A se expresa en todas las células y que Snai3 se expresa sólo en las que están infectadas con Snai3.

Cuando analizamos los resultados obtenidos en los FACS (Figura 27A), observamos que la sobre-expresión de Snai3 no tiene ningún efecto en la inducción de apoptosis, puesto que el porcentaje de células apoptóticas en las células sobreexpresando Snai 3 sin o con doxorrubicina es el mismo que el observado en los controles sin infectar. La pequeña bajada en el porcentaje de células apoptóticas cuando se compara con las células infectadas con Snai3 en ausencia de doxorrubicina con las células infectadas con el retrovirus vacío no es relevante, puesto que no es estadísticamente significativo.

El análisis de la expresión proteica de Puma (Figura 27B), una proteína critica en el proceso de apoptosis inducido por p53 (Han et al., 2001; Jeffers et al., 2003; Nakano and Vousden, 2001; Villunger et al., 2003), nos permitió observar el mismo efecto que en la Figura 27A, ya que no se ven diferencias en su expresión entre las células E1AMEFs infectadas con el retrovirus vacío y las células infectadas con Snai3. Lo que nos sorprendió fue observar un descenso en la forma activa de la Caspasa 3, que se ve desminuida en las células que sobre-expresan Snai3 cuando se compara con las células control (Mock). Las caspasas son enzimas importantes en el proceso de apoptosis donde las caspasas iniciadoras cortan a las caspasas efectoras activándolas de esta manera (Li and Yuan, 2008).

El hecho de que no exista variación en los niveles de Puma podría indicar que Puma no es importante en la mediación de apoptosis en este contexto celular, y quizá otra proteína pro-apoptótica, como es Noxa, podría estar implicada (Shibue et al., 2003). 
Sin embargo, debida a la ausencia de buenos anticuerpos contra Noxa, no pudimos estudiar la expresión de esa proteína.

\subsubsection{La sobre-expresión de Snai3 no induce apoptosis en MEFs p53 $^{-/}$}

Como ya hemos comentado, el proceso de apoptosis en células E1A-MEFs tras el tratamiento con doxorrubicina se induce de manera dependiente de p53. Las células E1A-MEFs sin p53, por lo tanto, se van a caracterizar en cultivo porque van a ser resistentes al proceso de apoptosis después de tratar las células con doxorrubicina (Attardi et al., 2004), y así van a ser inmortales, aunque las células infectadas con E1A van a estar sensibilizadas hacia la apoptosis.

Para eliminar las señalas inducidas por p53 que pueden afectar a la respuesta en el proceso de apoptosis estudiamos la respuesta apoptótica en células E1A-MEFs p53 ${ }^{-/}$. Por ello, sobre-expresamos Snai3 en las células E1A-MEFs p53 $3^{-/-}$y las tratamos con doxorrubicina durante 24 horas. A continuación, las analizamos de la misma manera que en el experimento anterior mediante FACS, marcando las células con Annexina-V y Ioduro de propidio.

Como se observa en la Figura 28A, no existen diferencias en el porcentaje de células apoptóticas entre las células E1A-MEFs $553^{-/-}$infectadas con el retrovirus vacío y las células E1A-MEFs p53 ${ }^{-/}$infectadas con Snai3, y como era de esperar, la respuesta apoptótica es menor en ausencia de p53 (tanto sin como con daño).

El mismo resultado fue observado cuando analizamos mediante Western Blot la expresión proteica de algunas proteínas implicadas en la apoptosis (Figura 28C). Tanto Puma como la Caspasa 3 activa no muestran diferencias en la expresión entre las células Mock y las que están infectadas con Snai3. El análisis de la expresión de Snai3 y de E1A nos permitió comprobar la infección de las células, ya que se ve la expresión de ambas proteínas en las células infectadas. Como en las células E1A-MEFs $\mathrm{p}^{-3^{--}}$no pudimos utilizar p53 como control de la inducción del daño por la ausencia de p53, hicimos uso de Snai1 (Figura 28B), ya que se sabe que su expresión transcripcional disminuye tras daño en el DNA de manera independiente de p53 (Perez-Mancera et al., 2005b). 
A

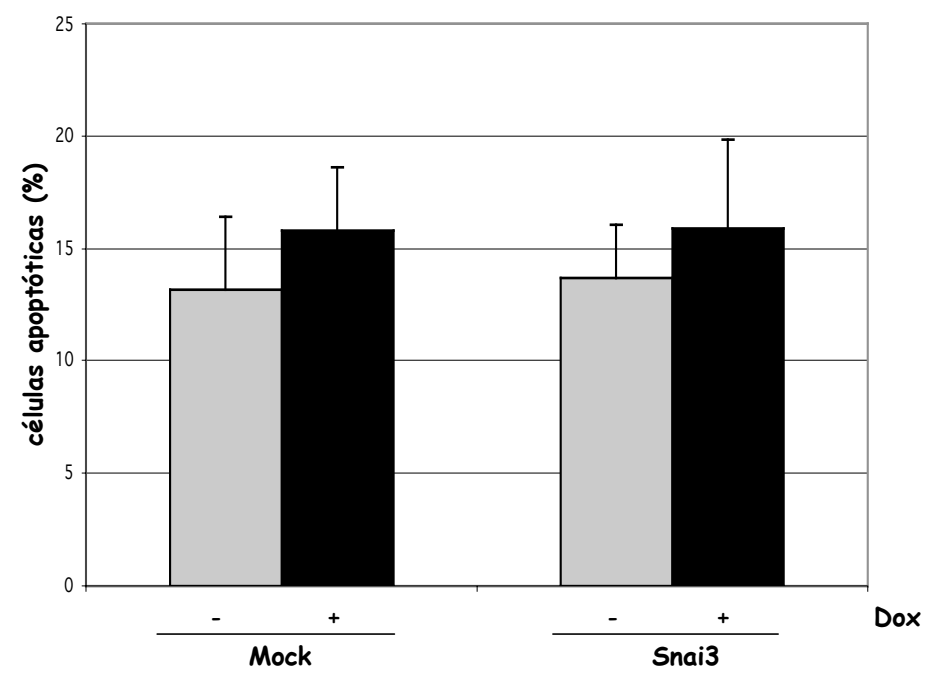

B
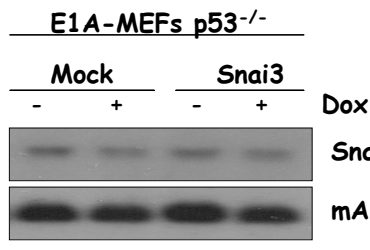

Snai1

mARPP-PO

c

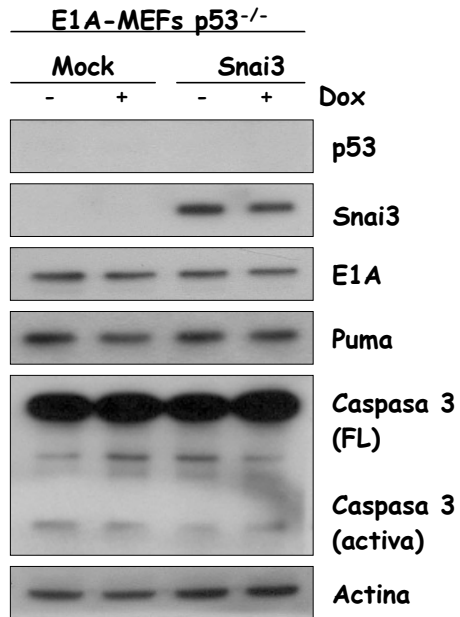

Figura 28: Estudio de la respuesta apoptótica en células E1A-MEFs $p 53^{-1-}$ que sobre-expresan Snai3. (A) La respuesta apoptotótica (porcentaje de células apoptóticas) en células E1A-MEFs p53 ${ }^{-1-}$ infectadas con el vector vacío (Mock) o con Snai3 tras el tratamiento con doxorrubicina $(0,2 \mathrm{\mu g} / \mathrm{ml}$ ) durante 24 horas. Las células fueron analizadas mediante FACS marcándolas con Annexina-V e IP $(0,5 \mu \mathrm{g} / \mathrm{ml})$ (B) Comprobación de la inducción del daño (Snai1) mediante Northern Blot. mARPP-PO fue utilizada como control de carga. (C) Comprobación de la infección (Snai3 y E1A) y análisis de la inducción de apoptosis (Puma; Caspasa 3 ) en los diferentes tipos celulares (Mock=sin infectar: Snai3=sobre-expresando Snai3) mediante el análisis de la expresión de proteínas por Western Blot. La actina confirma una carga similar en todas las muestras.

En base a los resultados obtenidos en relación con la posible implicación de Snai3 en el proceso de apoptosis en el contexto celular de los MEFs, observamos que Snai3 no va a tener una función importante en la inducción de la muerte celular, ya que no hemos observado diferencias relevantes entre los MEFs infectados con Snai3 y los MEFs infectados con el vector vacío.

Para determinar cual es la significación biológica del aumento en la expresión de Snai3 in vivo, generamos ratones que expresaran de forma constitutiva Snai3 (ratones CombitTA-Snai3). 


\subsubsection{Inducción de apoptosis en el timo de ratones que expresan Snai3 constitutivamente tras radiación- $\gamma$}

Como hemos comentado, ha sido descrito que Snai3 se expresa en el músculo esquelético y en el timo (Kataoka et al., 2000).

El timo es un tejido en el que se induce el proceso de apoptosis de manera dependiente de p53 (Lowe et al., 1993b). El hecho de que Snai3 este regulado de manera dependiente de p53 tras daño en el DNA en las células MEFs, y que Snai3 se exprese en el timo, nos hizo estudiar la inducción de apoptosis en el timo de ratones que sobre-expresan Snai3 tanto en el fondo genético wild-type (control) como en un fondo genético $\mathrm{p} 53^{-1-}$.

\subsection{Generación de ratones CombitTA-Snai3}

Con el fin de generar ratones que expresaran Snai3 constitutivamente, clonamos el cDNA de ratón de Snai3 en una versión modificada del vector CombitTA (Tet Off) (Schultze et al., 1996). Este sistema de expresión, reprimible por tetraciclina, utiliza un único elemento génico que permite tanto la regulación temporal como la regulación cuantitativa de la expresión del gen Snai3. Utilizando este vector, conseguimos sobreexpresar el gen Snai3 un 20\% sobre sus niveles endógenos.

Para la creación de los nuevos ratones transgénicos CombitTA-Snai3 se linearizó el vector con la enzima de restricción NotI y se purificó el fragmento de DNA que contenía los elementos reguladores de la expresión ligados al cDNA de Snai3. Este transgén fue inyectado en óvulos fertilizados de ratones híbridos CBAxC57BL/6J. Los óvulos pinchados fueron implantados en hembras pseudogestantes donde completaron la gestación. Para identificar los ratones transgénicos, tres semanas después del parto tomamos $2 \mathrm{~mm}$ de la colita de cada uno de los ratones nacidos. La detección del transgen en los distintos DNA genómicos se realizó del mediante técnica de Southern Blot tras la digestión del DNA con EcoRI. Utilizamos el cDNA de Snai3 de ratón como sonda para detectar el transgén.

Posteriormente, para llevar a cabo nuestros estudios en un fondo genético nulo para el supresor p53 cruzamos nuestros ratones CombitTA-Snai3 con ratones $\mathrm{p} 53^{-{ }^{-}}$. Se cruzaron hembras $\mathrm{p} 53^{+/-}$con machos CombitTA-Snai3. En la primera generación se obtuvieron aproximadamente un $25 \%$ de ratones con genotipo CombitTA-Snai3;p53 ${ }^{+/}$. Estos de nuevo se cruzaron con ratones $\mathrm{p} 53^{+-}$para obtener ratones CombitTA de todos 
los genotipos posibles para p53, entre ellos CombitTA-Snai3;p53 ${ }^{-/}$, objeto de nuestro estudio.

\subsection{Snai3 no induce apoptosis en ratones que sobre-expresan Snai3}

Para estudiar el papel de Snai3 en la inducción de apoptosis en timocitos de ratón, irradiamos ratones wild-type (control), ratones CombitTA-Snai3, ratones $p 53^{-/-}$y ratones CombitTA-Snai3;p53 ${ }^{-/}$de 4-6 semanas de edad con 2,5 Gy de radiación- $\gamma$.

La radiación- $\gamma$ es un carcinógeno que actúa directamente sobre el DNA induciendo el daño mediante roturas en la cadena simple y doble del DNA. La exposición de ratones a una dosis de 2,5 Gy de radiación- $\gamma$ induce una respuesta apoptótica extensa dependiente de p53 en tejidos radiosensibles, como son el timo, el bazo y el intestino (Christophorou et al., 2005).

5 horas tras de la irradiación sacrificamos estos ratones y analizamos la inducción de apoptosis en secciones histológicas de diferentes tejidos mediante el método de TUNEL.

La valoración de la apoptosis por el método de marcaje in situ del DNA fragmentado (técnica del TUNEL) tiene su fundamento en la detección de las roturas del DNA internucleosomal, típicos de la apoptosis, en secciones de tejidos incluidas en parafina. Las células apoptóticas serán visibles con fluorescencia verde, y el marcaje nuclear de todas las células se verá con DAPI en azul.

En la Figura 29 no se ve un aumento en la inducción de apoptosis tras daño en el DNA por radiación- $\gamma$ en los tejidos radiosensibles de los ratones CombitTA-Snai3 cuando se compara con la inducción de apoptosis en los tejidos de ratones control, que va a ser la misma en ambos casos. La inducción de apoptosis en los tejidos de los ratones del fondo genético $\mathrm{p} 53^{-/-}$no observa una respuesta apoptótica relevante tras la irradiación, ni en los ratones deficientes en p53, como era de esperar, ni en los CombitTA-Snai3;p53\%. 


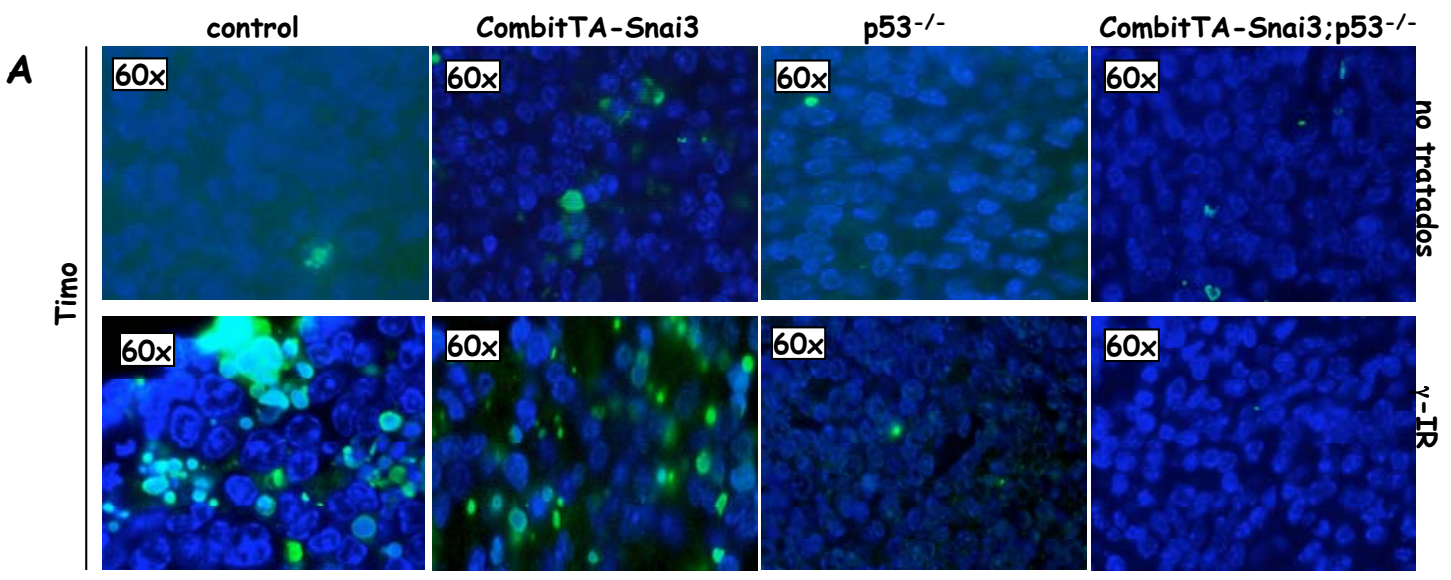

B
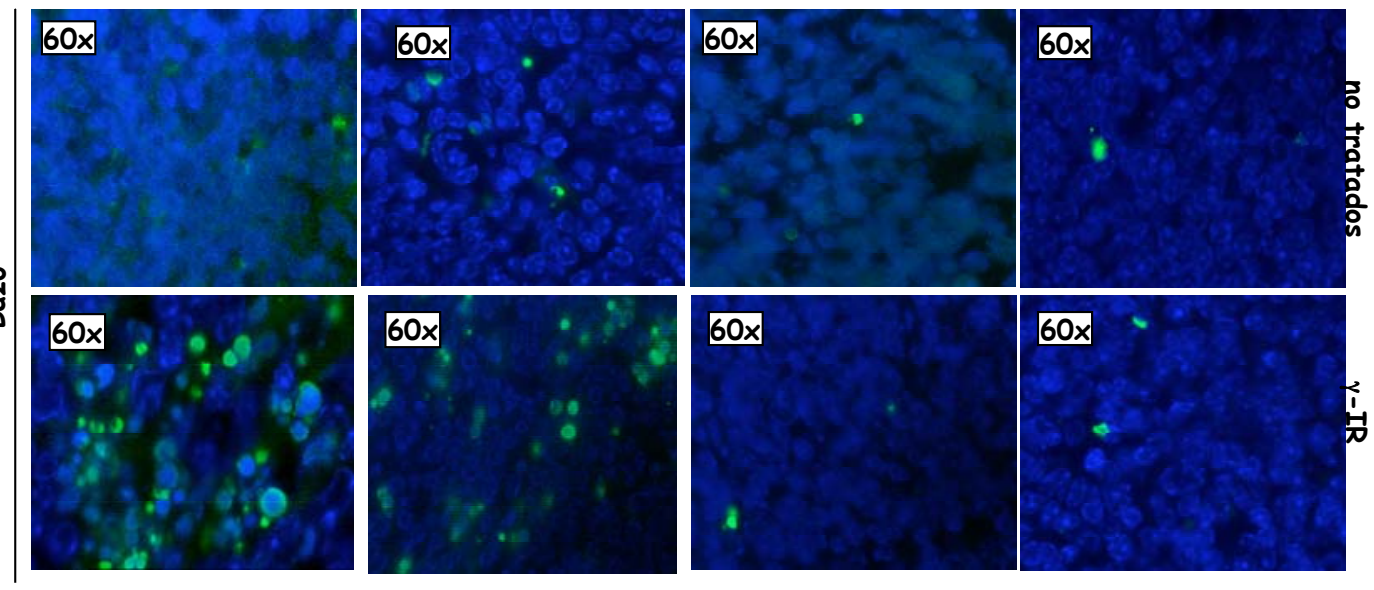

C

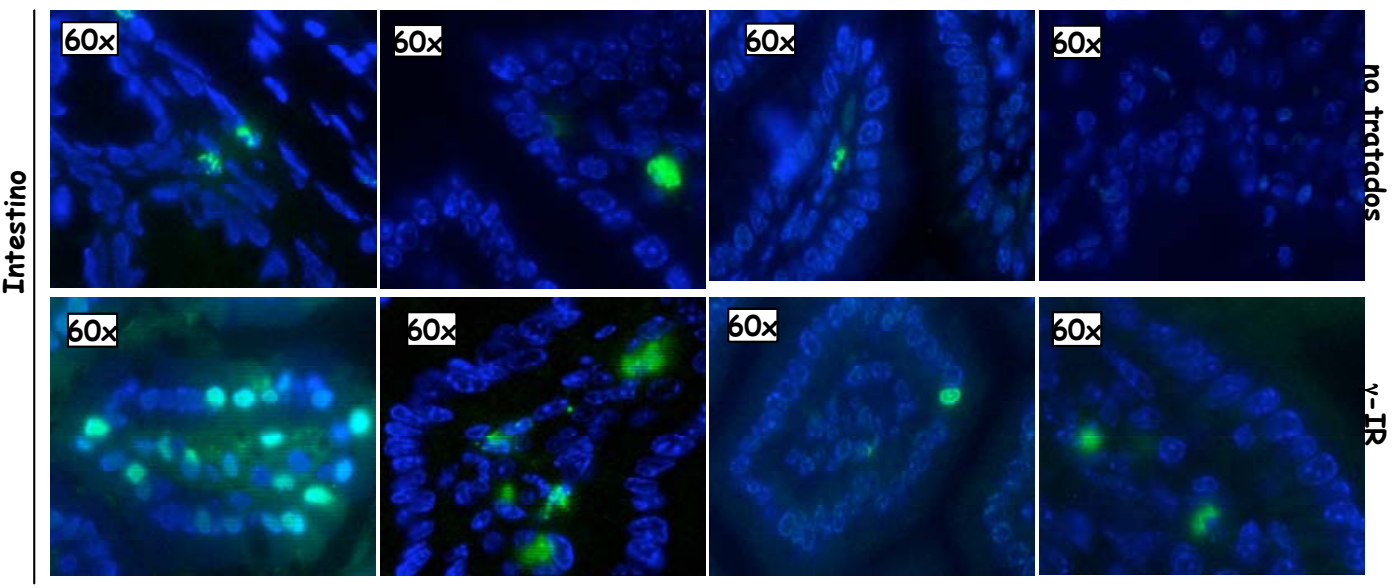

Figura 29: Inducción de la apoptosis en ratones que sobre-expresan Snai3 en un fondo genético

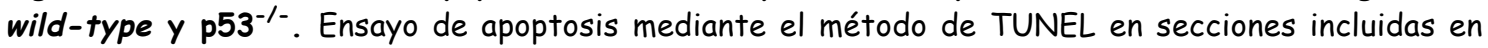
parafina de timo (A), de bazo (B) y de intestino $(C)$ de ratones wild-type (=control) (primera columna), CombitTA-Snai3 (segunda columna), p53/- (tercera columna) y CombitTA-Snai3;p53 columna) de 4-6 semanas expuestos a una dosis de 2,5 Gy de radiación- $\gamma$ (control=no tratados). Los tejidos fueron extraídos 5 horas después de la irradiación, y las células apoptóticas (positivas por TUNEL) aparecen en verde. El núcleo fue marcado con DAPI y aparece en azul. El aumento con el que se tomaron las imágenes es 600x. 
En el momento en que sacrificamos los ratones para coger los tejidos radiosensibles para su siguiente análisis por TUNEL, también cogimos una parte del timo para aislar los timocitos y analizarlos a su inducción de la apoptosis a nivel proteico. En la Figura 30A podemos ver mediante la expresión de la Caspasa 3 que sólo está inducido el proceso de apoptosis tras la radiación- $\gamma$ en los timocitos de los ratones control y CombitTA-Snai3, como se podría esperar, ya que ratones sin p53 son susceptibles a la inducción de tumorogénesis por irradiación (Kemp et al., 1994) y Snai3 no fue identificado como proteína pro-apoptótica en las células E1A-MEFs.

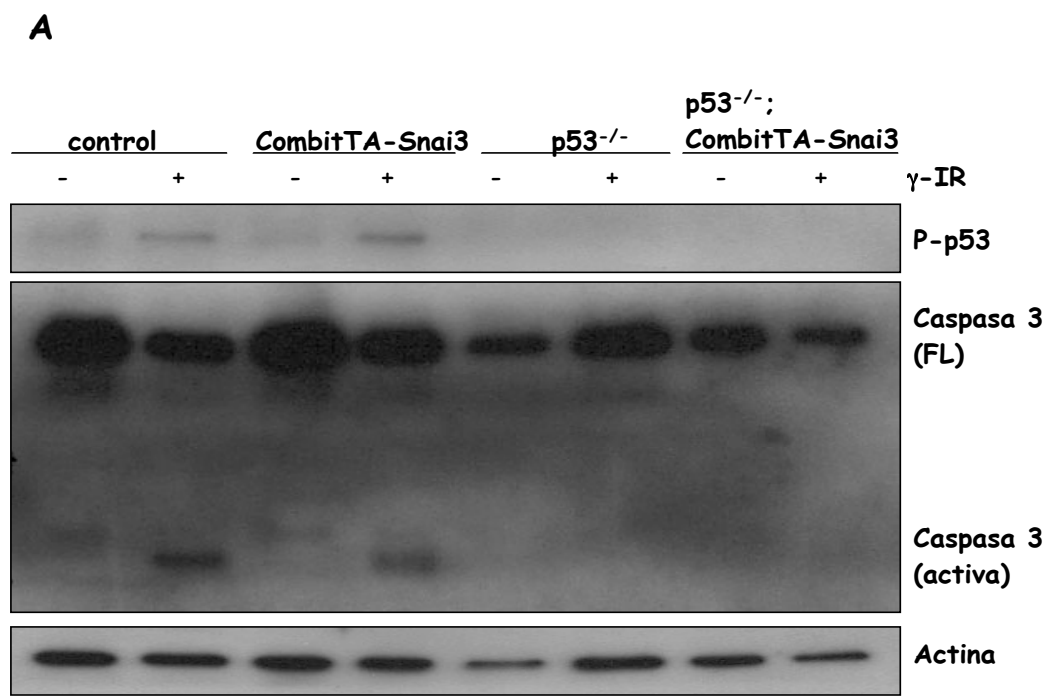

B

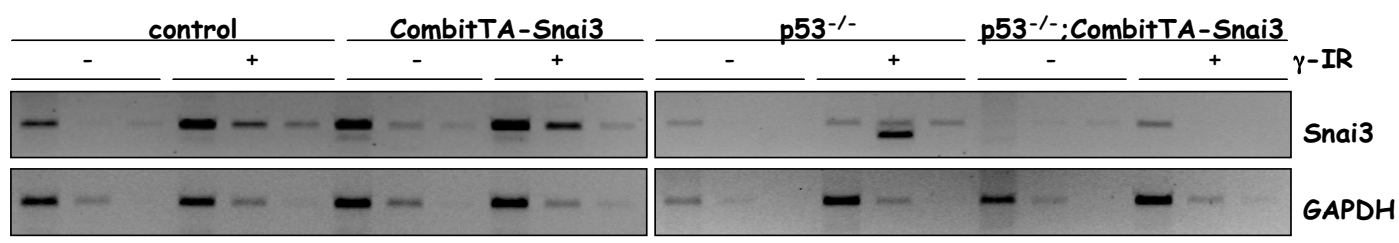

Figura 30: Análisis de la inducción de apoptosis y de la expresión de Snai3 en ratones que sobre-expresan Snai3. (A) Representación de la inducción de apoptosis tras radiación- $\gamma$ (2,5 Gy) en los ratones wild-type, CombitTA-Snai3, $\mathrm{p} 53^{-1-}$ y CombitTA-Snai3:p53 $3^{-1-}$ mediante Western Blot utilizando anti-cuerpos frente a la forma fosforilada de p53 y la Caspasa 3. Como control de carga fue utilizado la actina. (B) Comprobación de la expresión transcripcional de Snai3 en los timocitos de los ratones mediante RT-PCR semicuantitativa haciendo diluciones $1 / 5$ y $1 / 25$ a partir del CDNA original ampflificando un fragmento interno de Snai3 de aproximadamente 500pb. La GAPDH fue utilizado como control de carga.

El anticuerpo phospo-p53 fue utilizado para comprobar la inducción del daño, y como se puede ver se activa en los timocitos del fondo genético wild-type (los controles 
y los CombitTA-Snai3) tras daño en el DNA por radiación- $\gamma$. Lo que también observamos fue el pequeño descenso en la expresión proteica de la Caspasa 3 en los timocitos de los ratones CombitTA-Snai3 tras irradiacón comparados con los controles, igual que en las células E1A-MEFs infectadas con Snai3 tras daño en el DNA provocado con doxorrubicina.

Comprobamos también la expresión de Snai3 a nivel de RNA en estos ratones para detectar posibles diferencias entre los ratones que sobre-expresan Snai3 y los controles, ya que está descrito que Snai3 se expresa en el timo de ratones adultos (Kataoka et al., 2000). Vimos que varía el nivel de expresión transcripcional de Snai3 al mínimo en los ratones con el fondo genético wild-type entre los que tienen Snai3 sobreexpresado y los controles, puesto que se ve menos expresión en los ratones control (Figura 30B). En los ratones del genotipo p53 $3^{-/}$, tanto en los controles como en los que sobre-expresan Snai3, no se puede detectar apenas expresión de Snai3.

Resumiendo, los resultados obtenidos hasta ahora no identifican un papel relevante de Snai3 en el proceso de apoptosis tanto in vitro como in vivo en respuesta al daño en el DNA.

\subsubsection{Ciclo celular}

Como hemos explicado tras la exposición de células a estímulos estresantes p53 sería activado y induce sus dianas transcripcionales, las que finalmente eligen entre las respuestas celulares de la apoptosis o de la parada del ciclo celular (Vousden and Prives, 2005).

Dado que no vimos resultados concluyentes de una posible implicación de Snai3 en el proceso de apoptosis, pensamos estudiar el posible papel de Snai3 en el ciclo celular. Elegimos como en estudios anteriores el contexto celular de los MEFs sobreexpresando Snai3 en los mismos.

\subsubsection{Las células MEFs control que sobre-expresan Snai3 proliferan menos $y$ muestran un descenso en el porcentaje de células en fase $S$}

Empezamos estudiando el posible papel de Snai3 en ciclo celular mediante estudios de proliferación celular. Para ello infectamos células MEFs control con Snai3, y como 


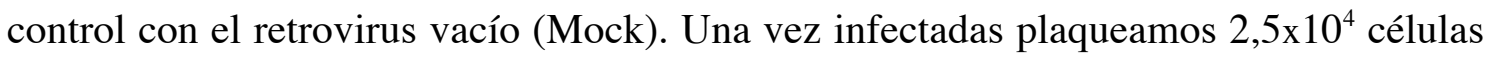
en placas de 12 pocillos y las contamos cada dos días durante 10 días (Figura 31).

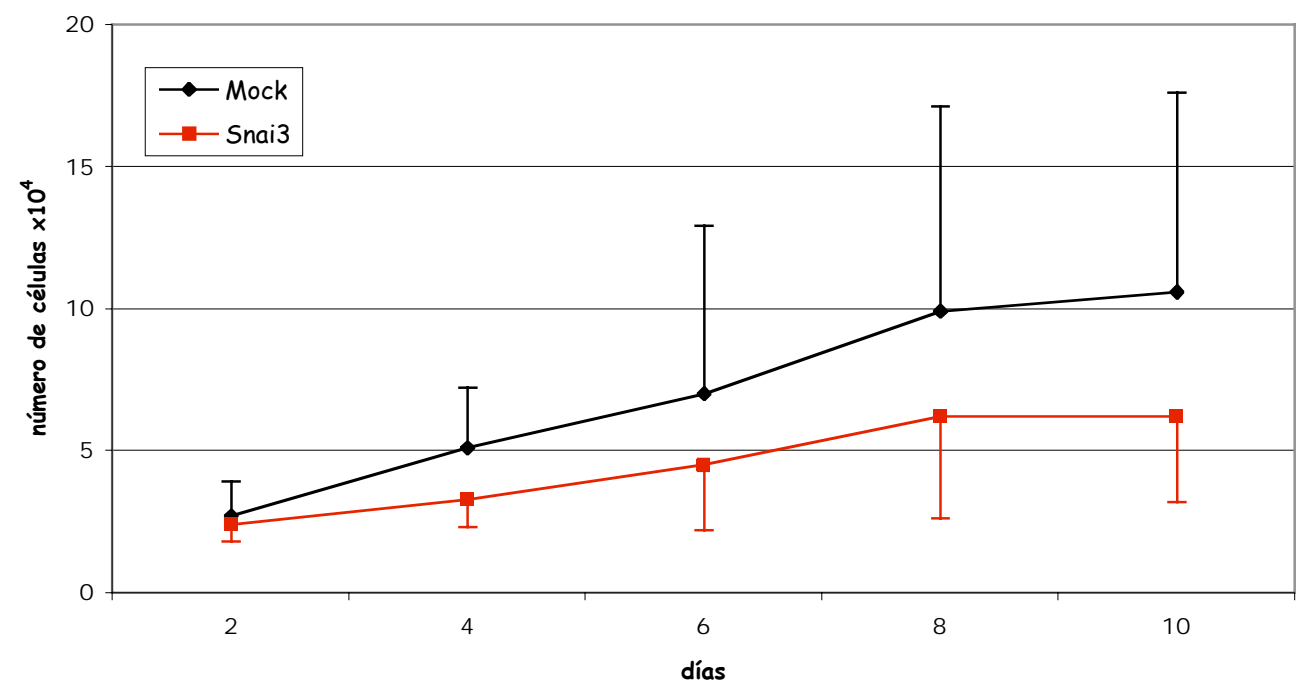

Figura 31: Análisis de la implicación de Snai3 en la proliferación celular en MEFs control. Estudio de la proliferación en las células MEFs control infectadas con el retrovirus vacío o con Snai3. Plaqueamos $2,5 \times 10^{4}$ células a tiempo cero en cada pocillo en placas de 12 pocillos y contamos las células en cada pocillo a día 2, 4, 6, 8 y 10 (para cada tiempo contamos 2 pocillos=por duplicado). $n=4$

Como podemos ver, las células infectadas con Snai3 proliferan menos al comparar con las células Mock.

Debido a los resultados obtenidos en los estudios de la proliferación celular quisimos saber a continuación si esta diferencia en la capacidad proliferativa también se podía detectar a nivel de ciclo celular en las células infectadas con Snai3 al compararlas con las células infectadas con el retrovirus vacío.

Para ello, como en los estudios anteriores, transfectamos células MEFs control con el retrovirus vacío o con Snai3, y a continuación las tratamos con doxorrubicina durante 24 horas. Tres horas antes de recoger las células, las cultivamos con Bromodeoxouridina (BrdU) para posteriormente recogerlas, marcarlas con anti-BrdU e IP y analizarlas mediante FACS (Figura 32). 


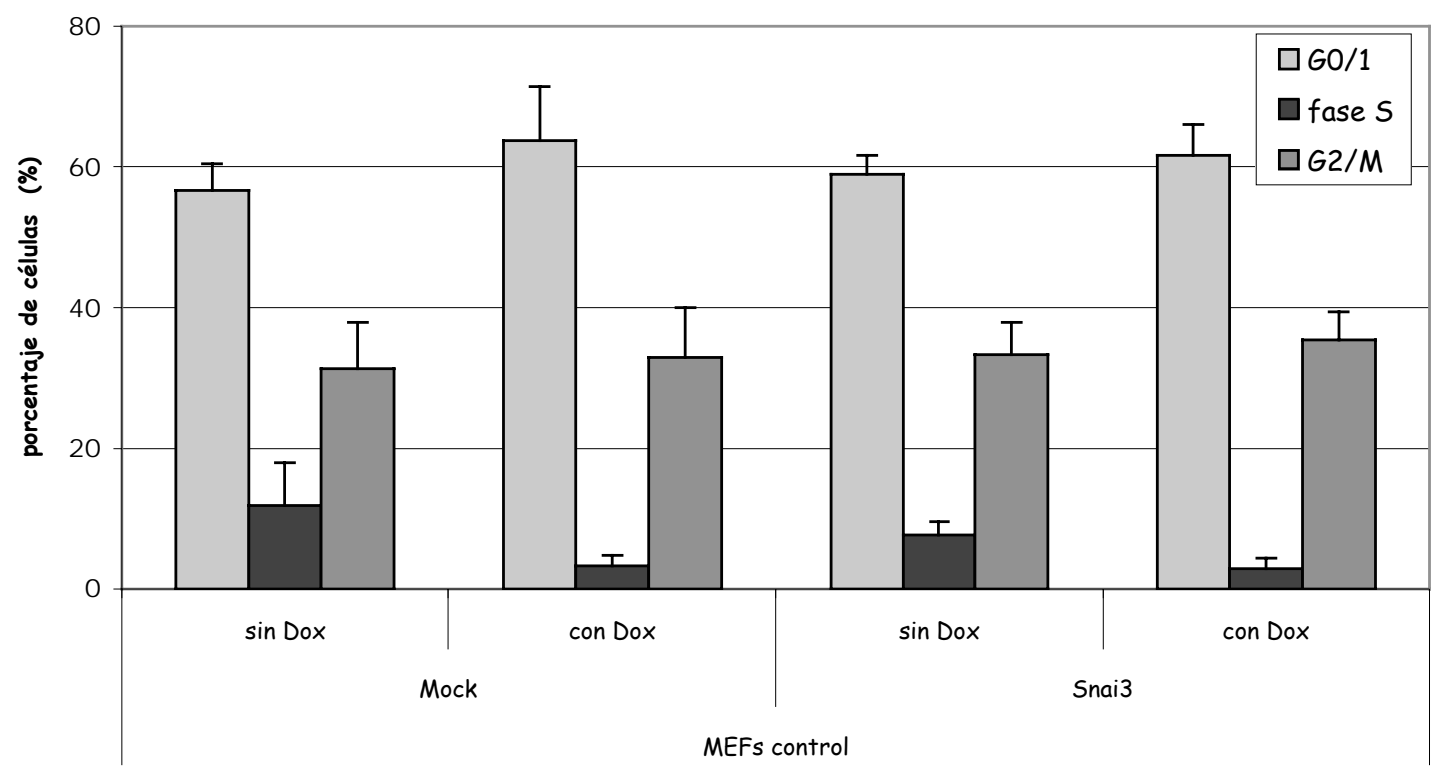

Figura 32: Análisis de ciclo celular en MEFs que sobre-expresan Snai3. Estudio del ciclo celular en células MEFs control infectadas con el retrovirus vacío y en MEFs infectadas con Snai3, sin y con daño (24 horas) en el DNA provocado por el tratamiento con doxorrubicina $(0,2 \mu \mathrm{g} / \mathrm{ml})$. Una vez infectadas y tratadas con Doxorrubicina las células fueron cultivadas con BrdU ( $1 \mathrm{mM}$ ). Posteriormente las marcamos con anti-BrdU y IP y las analizamos mediante FACS.

La BrdU es un análogo del nucleótido timidina, que va a ser incorporado específicamente en el DNA en lugar de la timidina (Dolbeare et al., 1983). El marcaje de las células con IP y anti-BrdU nos permite diferenciar entre las diferentes fases del ciclo celular, puesto que con IP se puede diferenciar entre las células con 2n en G0/1 y las células con 4n en G2/M, y con BrdU separamos las células que están sintetizando DNA (fase S).

Como se observa en la Figura 32, en las células MEFs infectadas con Snai3 disminuye el porcentaje de células que entran en fase $\mathrm{S}$, cuando se compara con las células infectadas con el retrovirus vacío, pasando de un $12 \%$ a un $7,5 \%$, respectivamente. Esto coincide con el resultado observado en el estudio de proliferación celular. En las células con daño no se ven diferencias entre las células Mock y las células con Snai3. Quizas por el hecho de que los MEFs control tratados con doxorrubicina sufren un arresto en la fase G1 del ciclo celular, y muestran un descenso en la entrada en la fase S (Attardi et al., 2004), y de esta manera no se detecta la diferencia.

Para buscar una explicación molecular a esa diferencia en la capacidad proliferativa que hemos observada tanto en el estudio de la proliferación celular (Figura 31) como en el estudio del ciclo celular en los MEFs control sin el tratamiento con 
doxorrubicina (Figura 32), analizamos la expresión de proteínas implicadas en la progresión del ciclo celular mediante Western Blot después de 12 y 24 horas de tratamiento con doxorrubicina (Figura 33). Para ello, elegimos p21 y Ciclina D1, que son proteínas que controlan la progresión en la fase G1 tardía (Harper et al., 1993; Sherr, 1994; Xiong et al., 1993).

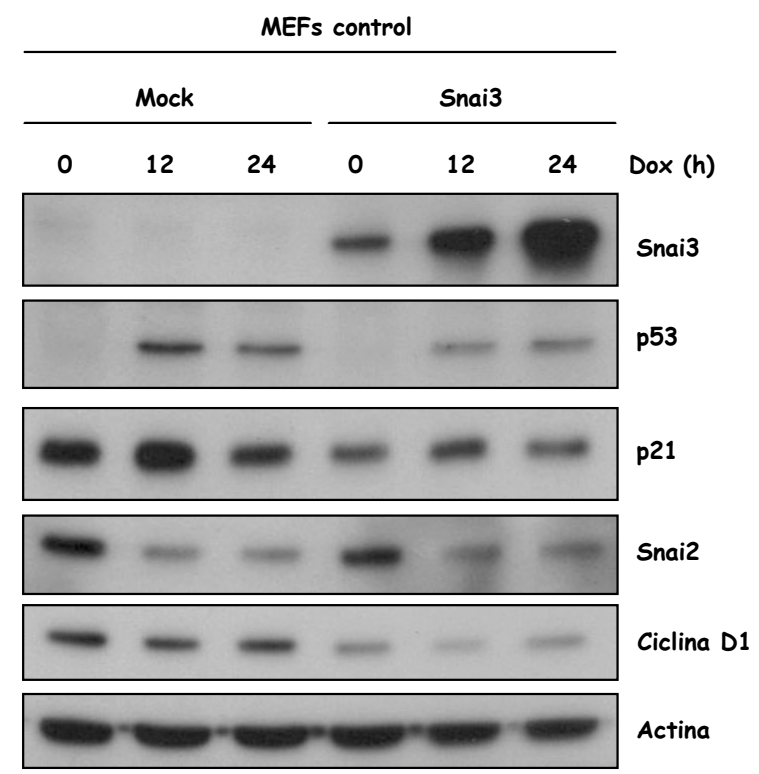

Figura 33: Análisis de la expresión de proteínas implicadas en el ciclo celular. p21 y Ciclina D1 son proteínas que controlan la progresión del ciclo celular en la fase S. Comprobamos también la infección (Snai3) y la inducción del daño (p53 y Snai2) mediante Western Blot. La expresión de actina confirma una carga similar en todas las muestras.

En la Figura 33 podemos ver la disminución en la expresión proteica de la Ciclina D1 tras el tratamiento con doxorrubicina en ambos tipos celulares, células Mock y células infectadas con Snai3, ya que el daño en el DNA induce la degradación de Ciclina D1 (Agami and Bernards, 2000; Alao, 2007) y esto ha sido relacionado con una menor capacidad proliferativa. Pero también observamos una disminución en la expresión proteica de la Ciclina D1 en las células que sobre-expresan Snai3 cuando se compara con las células Mock, tanto en ausencia como en presencia de daño en el DNA provocado por el tratamiento con doxorrubicina. Esto coincide con el resultado observado en el estudio de proliferación.

Sin embargo, también observamos que la expresión de p21 disminuye en las células infectadas con Snai3 cuando se compara con las células Mock. p21 es una proteína de la familia de inhibidores de quinasas dependientes de ciclinas, y una diana transcripcional directa de p53, que induce la parada del ciclo celular (el-Deiry et al., 1993; Harper et al., 1993; Xiong et al., 1993). Por eso, no es lógico ver un descenso en 
la expresión de p21 en las células infectadas con Snai3, puesto que Snai3 parece estar asociado con un descenso en la proliferación.

El análisis de la expresión de Snai3 y p53 (Figura 33), nos permitió comprobar la eficiencia de la infección y la inducción del daño en el DNA, y también detectamos la expresión de Snai2, ya que hemos visto en nuestro laboratorio que la expresión de Snai2 disminuye tras daño en el DNA en MEFs.

\subsubsection{Las células MEFs p53 $^{-/-}$que sobre-expresan Snai3 no muestran un comportamiento diferente ni en la proliferación, ni en el ciclo celular}

Puesto que Snai3 parece tener un posible papel en el ciclo celular en el contexto de los MEFs control quisimos estudiar a continuación esta función de Snai3 en células MEFs $\mathrm{p} 53^{-1-}$.

De la misma manera que hicimos en las células MEFs control, inicialmente realizamos un estudio de la proliferación. Para ello infectamos células MEFs $\mathrm{p}^{-/-}$con Snai3 o con el retrovirus vacío, como control negativo. Una vez infectadas, plaqueamos estas células en placas de 12 pocillos con una confluencia de $2,5 \times 10^{4}$ células por pocillo, y las contamos cada dos días durante 10 días. El experimento se hizo por duplicado, de manera que cada día contamos 2 pocillos.

Como podemos ver en la Figura 34, se ve un pequeño descenso en la proliferación de las células infectadas con Snai3, cuando se compara con la proliferación de las células infectadas con el retrovirus vacío (Mock), hasta el día 6. Esto coincide con el resultado obtenido en el estudio de proliferación en células MEFs control. A partir del día 6, ambos tipos celulares van a presentar un número de células similar, pero esto será debido a que en este tiempo, debido a la elevada tasa de proliferación de los MEFs p53 ${ }^{-/}$, los cultivos ya están confluentes y no pueden seguir proliferando (Attardi et al., 2004).

Puesto que la expresión de Snai3 parece afectar a la capacidad proliferativa de los MEFs p53 ${ }^{-/}$, a continuación realizamos un estudio de ciclo celular en el contexto de MEFs sin p53 infectados con el retrovirus vacío o con Snai3. Para ello, una vez infectadas las células las cultivamos en ausencia o en presencia de doxorrubicina durante 24 horas y 2 horas antes de recogerlas añadimos BrdU para que la incorporen en vez del nucleótido timidina. Como hemos explicado anteriormente, el marcaje de las 
células con IP y anti-BrdU nos permite diferenciar entre las células proliferando y las que estaban paradas en una de las fases G0/1 o G2/M.

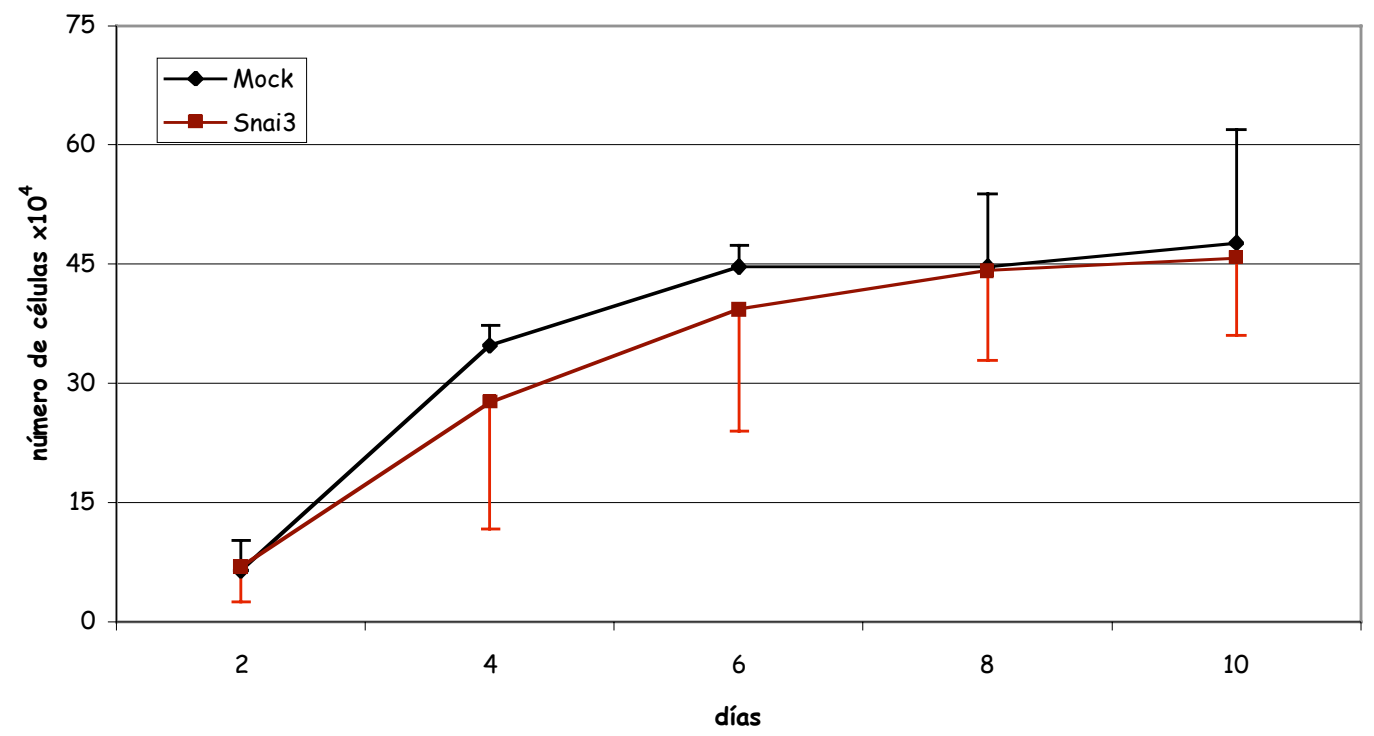

Figura 34: Análisis de la implicación de Snai3 en la proliferación celular en MEFs $\mathrm{p} 53^{-1-}$. Estudio de proliferación en células MEFs sin p53 infectadas con el retrovirus vacío o con Snai3. Plaqueamos $2,5 \times 10^{4}$ células a tiempo cero en cada pocillo en placas de 12 pocillos y contamos las células en cada pocillo a día $2,4,6,8$ y 10 (para cada tiempo contamos 2 pocillos=por duplicado). $n=5$

Como se observa en la Figura 35, las células MEFs sin p53 tratadas con doxorrubicina muestran una reducción dramática en el número de células en la fase G0/1, lo que va a ser debido a un defecto en el arresto en la fase G1, y así las células van a quedar paradas en la fase $S$ tras incorporar la BrdU (Attardi et al., 2004). Esto es lo que observamos, como era de esperar, en las células Mock, que utilizamos como control en nuestro estudio. Las células infectadas con Snai3, cuando se compara con las células infectadas con el retrovirus vacío, presentan un comportamiento parecido, ya que tanto sin doxorrubicina como con doxorrubicina muestran porcentajes similares de células en cada fase del ciclo celular, aunque en las células infectadas con Snai3 existe un ligero aumento en el porcentaje de las células en la fase $\mathrm{S}$. 


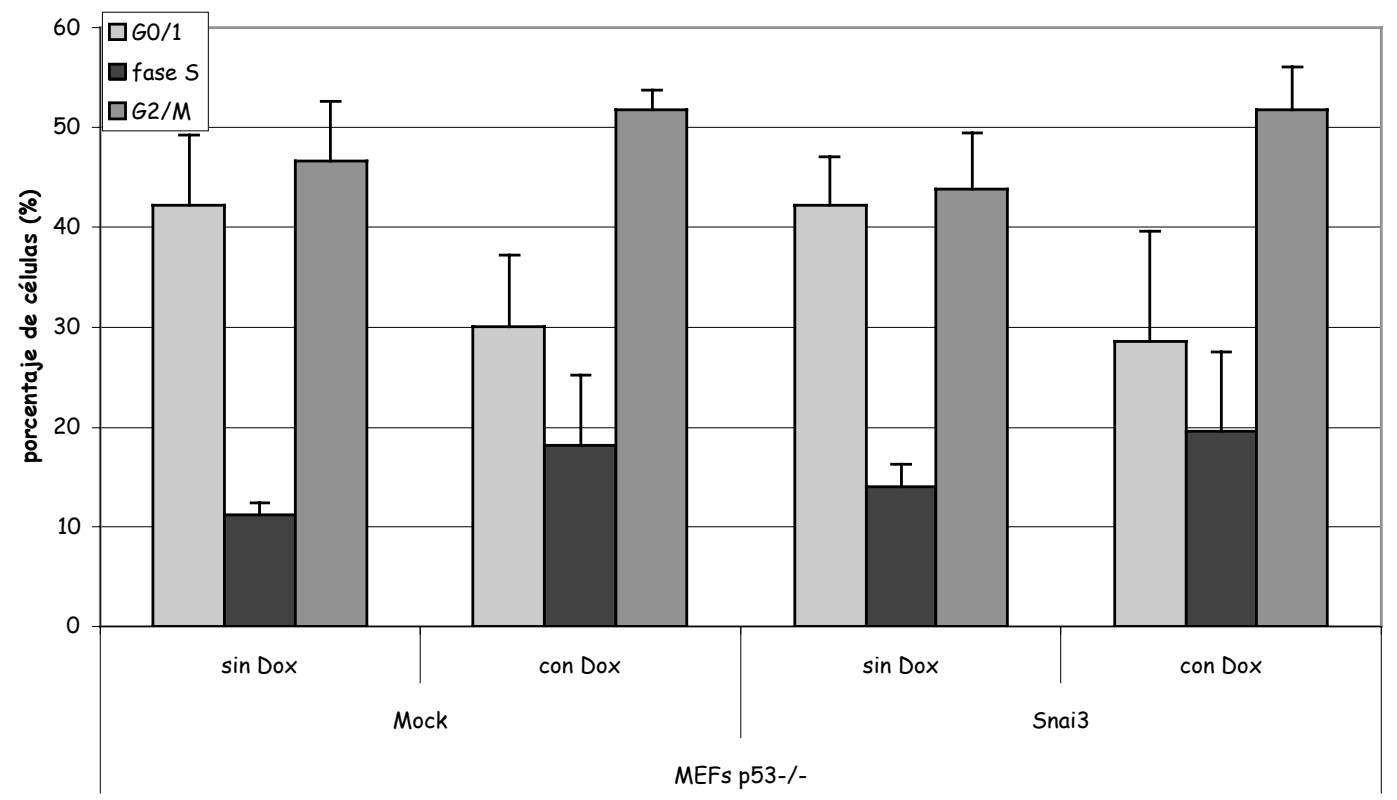

Figura 35: Análisis del ciclo celular de los MEFs $p 53^{-1-}$ que sobre-expresan Snai3. Estudio del ciclo celular en células MEFs sin p53 infectadas con el retrovirus vacío o con Snai3, sin y con daño en el DNA por doxorrubicina (24 horas; $0,2 \mathrm{mg} / \mathrm{ml}$ ). Las células fueron marcadas con anti-BrdU y con IP y analizadas mediante FACS.

Analizamos la expresión proteica de p21 y Ciclina D1 (Figura 36B) en las células MEFs $\mathrm{p}^{-/-}$infectadas con el retrovirus vacío o con Snai3 y tratadas con doxorrubicina durante 0,12 y 24 horas. Puesto que p21 es una diana de p53 (el-Deiry et al., 1993), en ausencia de p53 no pudimos detectar la expresión de p21 como era de esperar, así como tampoco la expresión de p53. En cuanto a la expresión de Ciclina D1 en las células infectadas con Snai3, no se puede detectar una gran diferencia cuando se compara con la de las células Mock, aunque sí parece existir un ligero descenso en su expresión. Esto coincide con el hecho de que las células MEFs sin p53 infectadas con Snai3 proliferan menos que los controles infectados con el retrovirus vacío. Como en estudios anteriores, analizamos la expresión de Snai3 para comprobar la eficiencia de la infección de las células, en este caso tanto mediante Northern Blot (Figura 36A) como mediante Western Blot (Figura 36B). También comprobamos la inducción del daño al DNA provocado por el tratamiento con doxorrubicina mediante la expresión transcripcional de Snai1 (Figura 36A), ya que se sabe que disminuye tras daño en el DNA de manera independiente de p53 (Perez-Mancera et al., 2005b). La expresión de Snai2 nos sirve como control del daño (Figura 36B), puesto que su expresión no cambia en células MEFs sin p53 tras daño en el DNA por doxorrubicina (datos observados en nuestro laboratorio, aún no publicados). 
A

MEFs p53-1-

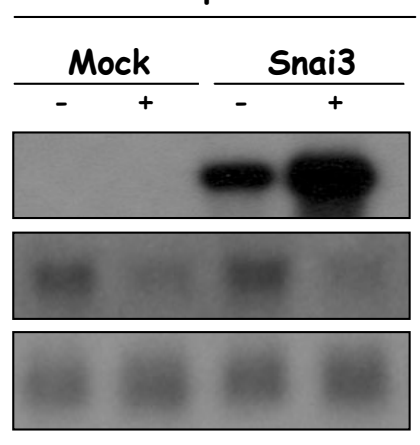

B

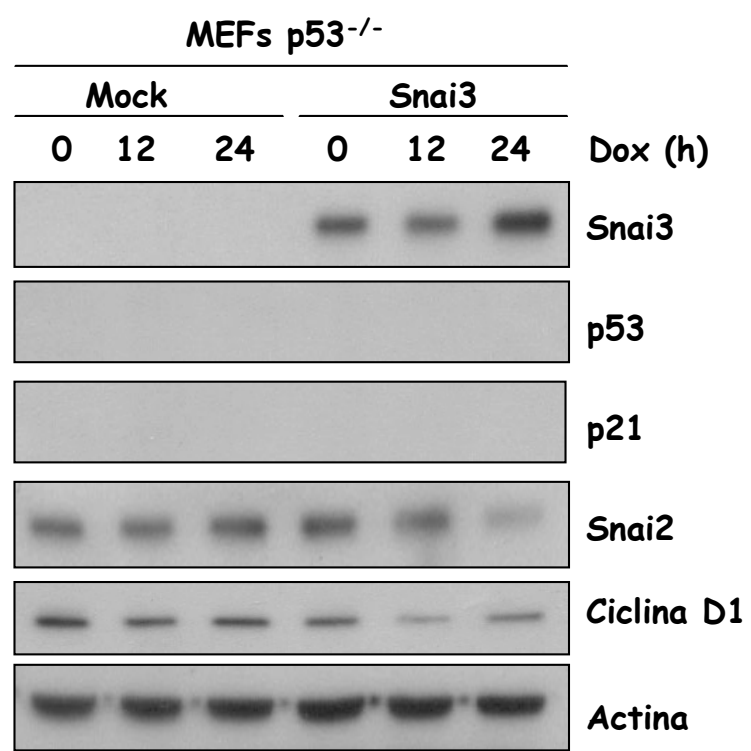

Figura 36: Análisis moleculares mediante Northern Blot y Western Blot. (A) Comprobación de la infección de las células y del daño mediante la expresión transcripcional de Snai3 y Snail respectivamente. Como control de carga fue utilizado mARPP-PO. (B) Representación de la expresión de proteínas implicadas en el ciclo celular (p21, Ciclina D1) y comprobación de la infección (Snai3) y del daño (Snai2) mediante Western Blot. La expresión de actina nos confirma una carga similar en todas las muestras.

En resumen, podemos decir que nuestros resultados nos muestran que Snai3 está regulado tras el daño en el DNA provocado por el tratamiento con doxorrubicina en células MEFs, y que esta regulación va a ser dependiente de p53. Dentro de las vías que se inducen tras daño en el DNA en las que está estrechamente implicado p53, Snai3 parece participar en la parada del ciclo celular, puesto que hemos observado una menor capacidad de proliferación y un descenso en la entrada en la fase $\mathrm{S}$ del ciclo celular en los MEFs infectados con Snai3.

\section{El papel de Snai3 en la tumorogénesis}

Como hemos explicado anteriormente, en los últimos años varios estudios han puesto de manifiesto la participación tanto de Snai1 como de Snai2 en el cáncer humano (Blanco et al., 2002; Cheng et al., 2001; Elloul et al., 2005; Hajra et al., 2002; Inukai et al., 1999; Khan et al., 1999; Rosivatz et al., 2002; Saito et al., 2004; Sugimachi et al., 2003; Tripathi et al., 2005a; Tripathi et al., 2005b; Uchikado et al., 2005).

En nuestros estudios in vitro con MEFs hemos observado que tras daño en el DNA (provocado por el tratamiento con doxorrubicina) Snai3 está regulado de manera 
directa por p53. Por otro lado también se observa una menor capacidad proliferativa así como un descenso en la fase $\mathrm{S}$ del ciclo celular. Sin embargo, es muy poco lo que se conoce sobre la posible implicación de Snai3 en la génesis del cáncer.

El análisis de la hibridación genómica comparada (del inglés, comparative genomic hybridizayion $(\mathrm{CGH})$ ) ha puesto de manifiesto tanto pérdidas como amplificaciones de la región genómica o parte de ella que contiene al gen SNAI3 (cromosoma 16q24.3) en un amplio espectro de tipos de tumores humano (Tabla 1).

\begin{tabular}{|c|c|c|}
\hline TIPO DEL TUMOR & Pérdida & Amplificación \\
\hline Linfoma difuso de célula grande del estómago & & $\begin{array}{l}16 q 22-q \text { ter } \\
16 q 23-q 24\end{array}$ \\
\hline Carcinoma nasofaríngeo & 16q23-q24 & \\
\hline Cáncer de pulmón de células pequeñas & $16 q^{*}$ & \\
\hline Carcinoma neuroendocrino de pulmón & $16 \mathrm{q}$ & \\
\hline Carcinoma hepatocelular & $\begin{array}{c}16 q \\
16 q^{*} \\
16 q 21-q 24\end{array}$ & \\
\hline Carcinoma hepatocelular, primario & $16 \mathrm{q}$ & \\
\hline Carcinoma hepatocelular metástasis & $16 \mathrm{q}$ & \\
\hline Carcinoma esofágico & 16924 & \\
\hline Adenocarcinoma de la unión esofagogástrica & 16q23-q ter & \\
\hline Carcinoma gástrico, primario & $16 \mathrm{q}$ & \\
\hline Tumor adrenocortical, de niños & & 16 \\
\hline Tumor endocrino pancreático & & 16 \\
\hline Carcinoma timico de células squamous, primario, timoma tipo $\mathrm{C}$ & 16q13-q24 & \\
\hline Cáncer de mama & $16 \mathrm{q}$ & \\
\hline Carcinoma de mama, grado I & 16q23-q ter & \\
\hline Carcinoma de mama, grado II & $16 q 23-q$ ter & \\
\hline Carcinoma de mama, ductal in situ & $16 q 22-q$ ter & \\
\hline Tumor de Wilms & 16q & \\
\hline Carcinoma de vejiga & $16 q 21-q \operatorname{ter}^{*}$ & \\
\hline Carcinoma de vejiga papilar no invasivo, bajo grado & $16 q 22-q$ ter & \\
\hline Carcinoma de vejiga invasivo urinario & $16 q 12-q$ ter & \\
\hline
\end{tabular}

\begin{tabular}{|c|c|c|}
\hline TIPO DEL TUMOR & PÉRDIDA & AMPLIFICACIÓN \\
\hline Oligodendroglioma bien diferenciado & & $16 \mathrm{q} 21-\mathrm{q}$ ter \\
\hline Oligodendroglioma anaplásico & $16 \mathrm{q}$ & \\
\hline Glioma & $16 \mathrm{q}$ & \\
\hline Neuroblastoma & $16 \mathrm{q} 21-\mathrm{q}$ ter & \\
\hline Meduloblastoma & $\begin{array}{c}\mathbf{1 6 q} \\
16 \mathrm{q} 21-\mathrm{q} \text { ter }\end{array}$ & \\
\hline Melanoma de ojo & $16 q 12-q$ ter & \\
\hline Cáncer de ovarios & $16 q^{*}$ & \\
\hline Cáncer de ovarios, esporádico e inherited & $16 \mathrm{q} 22-\mathrm{q} 24$ & \\
\hline Carcinoma de trompa de falopio & $16 q 22-q$ ter & \\
\hline Testis & $16 \mathrm{q}$ & \\
\hline Cáncer de Próstata & $\begin{array}{l}\mathbf{1 6 q}^{*} \\
16\end{array}$ & \\
\hline Osteosarcoma & 16 q22-q ter & $16 \mathrm{q}$ \\
\hline Tumor de Ewing & $16 \mathrm{q}$ & \\
\hline Liposarcoma & $16 \mathrm{q}$ & 16 \\
\hline Leiomiosarcoma & $16 \mathrm{q}$ & \\
\hline Sarcomas primarios y sus metástasis pulmonares & $\begin{array}{c}16 \mathrm{q} 21-\mathrm{q} \text { ter } \\
16 \mathrm{q}\end{array}$ & \\
\hline
\end{tabular}

Tabla 1: La pérdida de la región o parte de ella $\left(^{*}\right)$ del gen SNAI3 o la amplificación de secuencias recidivas del DNA que envuelven $16 q$ en neoplasias humanas evaluado mediante el análisis de la hibridación genómica comparativa (CGH). Esta información se ha obtenido de http://www.helsinki.fi/cmg/cgh data.html.

Así pues, parece que la implicación de SNAI3 en el cáncer humano pueda ser más amplia de lo que inicialmente se esperaba.

\subsection{Snai3 está implicada en el desarrollo de cáncer en ratones}

Para determinar el efecto de la expresión de Snai3 en la malignidad in vivo, generamos ratones transgenicos utilizando el sistema CombitTA, como hemos explicado anteriormente, el cual fue ya utilizado en nuestro laboratorio para los estudios de la implicación de Snai1 y Snai2 en el desarrollo del cáncer (Perez-Mancera et al., 2005a; 
Perez-Mancera et al., 2005b). La presencia de un promotor reprimible por doxiciclina en el vector de expresión de Snai3, nos iba a permitir además, apagar o encender su expresión mediante la adición o retirada de doxiciclina, respectivamente.

Para el estudio de la implicación de Snai3 en el desarrollo del cáncer hemos utilizado un total de 33 ratones CombiTA-Snai3 (9 corresponden a la línea 89A y 24 a la línea 89B) y 20 ratones control. Las dos líneas de ratones CombitTA-Snai3 presentaban un fenotipo similar. Los ratones CombitTA-Snai3 nacen con frecuencia normal, se desarrollan con normalidad, sin anomalías morfológicas y son totalmente fértiles. Las necropsias y los estudios histológicos de los animales jóvenes CombitTASnai3 no evidenció ningún tipo de alteración, lo que demuestra el nivel de expresión exógena de Snai3 no interfiere con el desarrollo embrionario y pos-natal. Sin embargo, con el paso del tiempo hemos observado que estos ratones tenían una vida media más corta que los ratones control y a los 16 meses la tasa de supervivencia se reducía a la mitad (Figura 37).

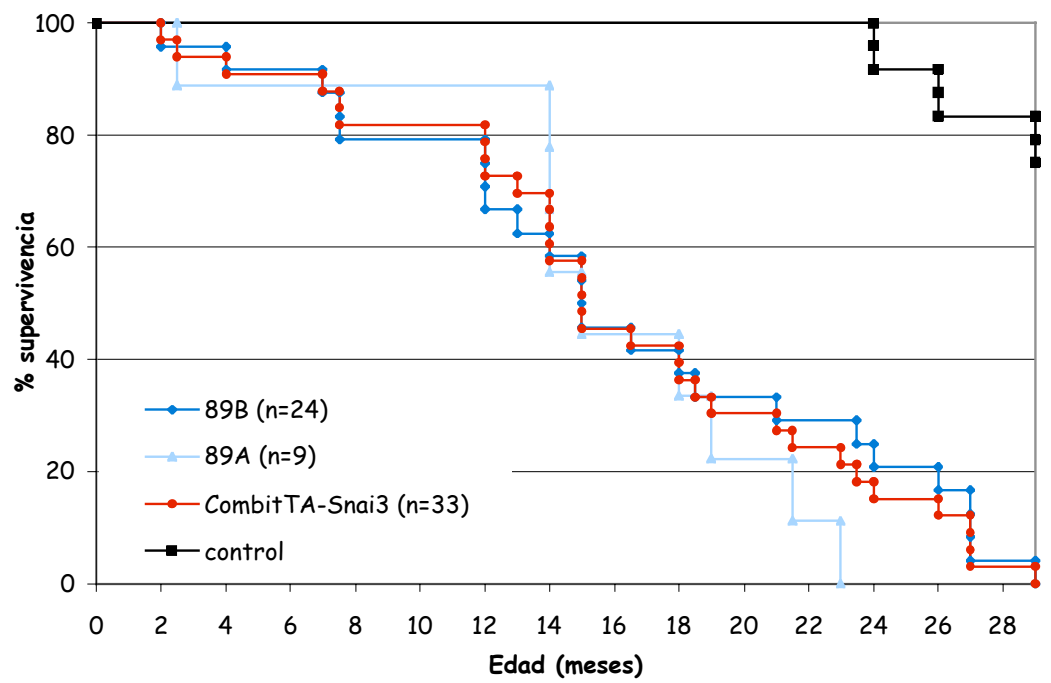

Figura 37: Curva de supervivencia de ratones CombitTA-Snai3 frente a ratones control utilizando el método de Kaplan-Meier. De los ratones CombitTA-Snai3 existen 2 líneas, 89A y 89B, los cuales están representados por separadas (las líneas azules) y también en una curva juntas (línea roja). Los ratones CombitTA-Snai3 tienen una vida media de 16 meses (línea roja) frente a los 24 meses de los ratones control.

En general, la mayoría de los ratones CombitTA-Snai3 enfermaban a partir de 10 meses de edad. La necropsia de estos ratones puso de manifiesto el desarrollo de tumores los cuales en su mayoría eran de origen mesenquimal, aunque también se 
encontraron tumores de origen epitelial (Figura 38). El 95\% de los tumores mesenquimales eran tumores hematopoyéticos (73\% tumor mieloide, 16\% linfoma similar a Malt y $11 \%$ linfoma de bajo grado) y los $5 \%$ restantes sarcomas de alto grado.

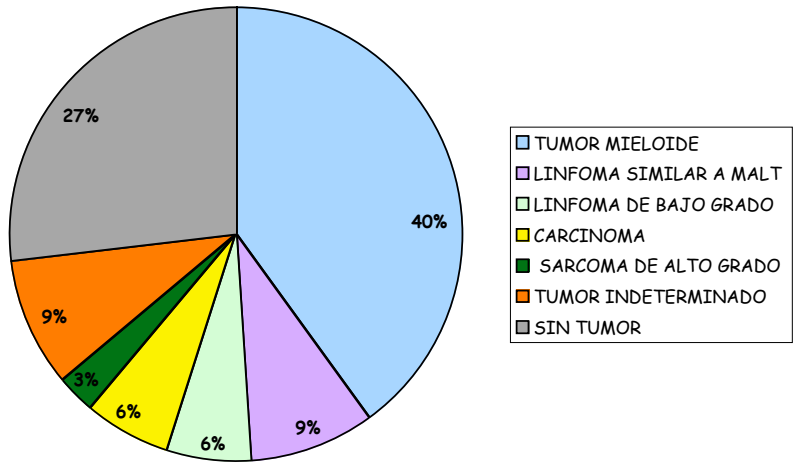

Figura 38: Distribución de tumores en ratones CombitTA-Snai3. Frecuencias relativas de los tipos de tumores observados en ratones CombitTA-Snai3. Como se observa en la figura, con gran frecuencia se desarrolla un tumor mieloide.

Los análisis histo-patológicos de los tumores epiteliales determinaron la presencia adenocarcinomas de pulmón (Figura 39) y en un ratón observamos un carcinoma uterino. La evaluación histológica no puso de manifiesto una diseminación de los mismos.
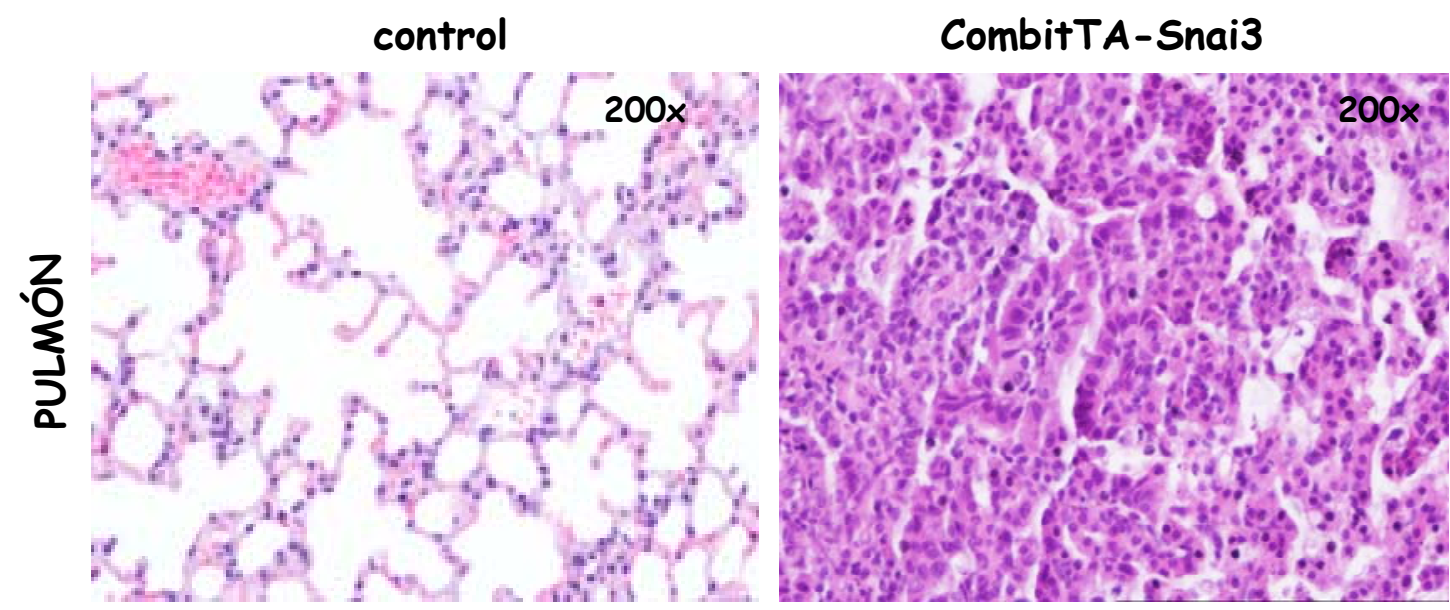

Figura 39: Masa tumoral de un Adenocarcinoma con patrón papilar. Tinción hematoxilina-eosina de cortes histológicos de pulmón (aumento 200x).

El estudio anatomo-patológico de los tumores mesenquimales hallados en 13 de los ratones CombitTA-Snai3 analizados, reveló que los tumores se correspondían con un tumor mieloide en el bazo y/o en el hígado (Figura 40), que además estaba 
infiltrando muy diversos tejidos, como son pulmón, bazo, hígado y ganglio mediastínico.
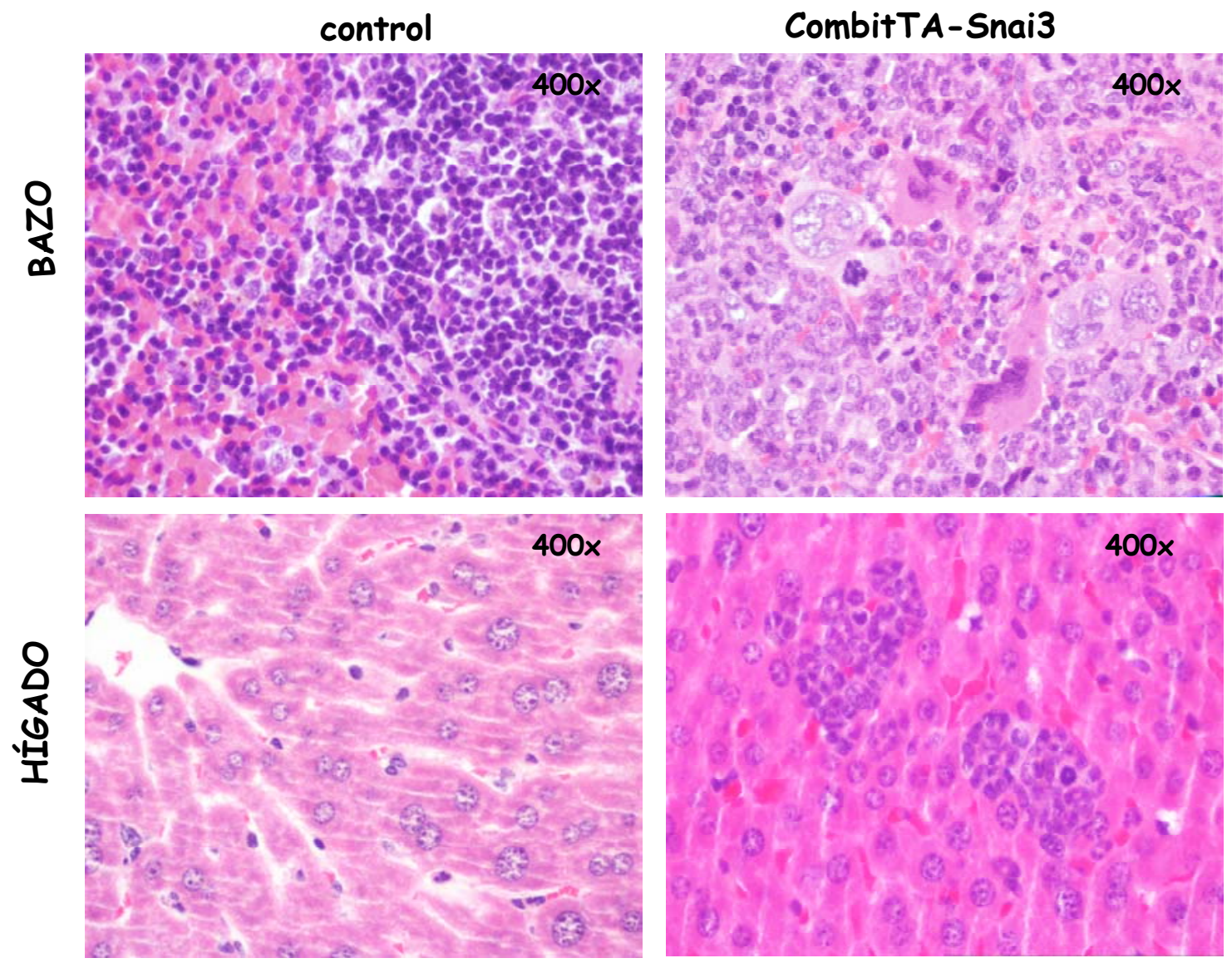

Figura 40: Masas tumorales de un tumor mieloide en el bazo y en el hígado. Tinción hematoxilina-eosina de cortes histológicos de bazo (aumento 400x) y hígado (aumento 400x) donde se observa infiltración tumoral en el tejido.

El análisis de sangre periférica mediante citometría de flujo de ratones CombiTA-Snai3 identificó células mieloides $\left(\mathrm{Gr}^{+} \mathrm{Mac1}^{+}\right)$aberrantes en sangre periférica (Figura 41) confirmando de esta manera que el tumor observado en el análisis anatomo-patológico. El carácter tumoral de estas células mieloides infiltrantes se puso de manifiesto al observar que estas coexpresan marcadores mieloides junto con marcadores de otras líneas linfoides (CD8) (Figura 41). 

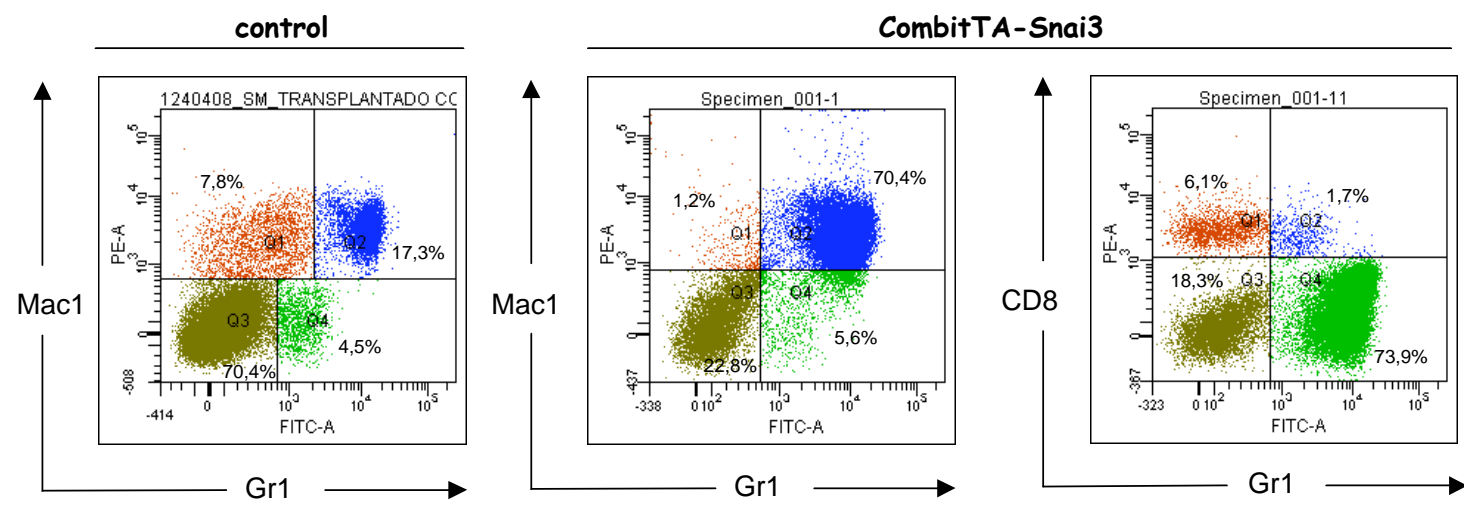

Figura 41: Análisis inmunofenotípico de sangre periférica de ratones CombitTA-Snai3. Las células (10000) fueron marcadas con anticuerpos específicos para identificar el porcentaje de células mieloides $\left(\mathrm{Mac1}^{+} \mathrm{Gr} 1^{+}\right)$y el porcentaje de células anormales $\left(\mathrm{CD} 8^{+} \mathrm{Gr} 1^{+}\right)$.

Además, en dos de estos ratones los estudios anatomo-patológicos demostraron la presencia de un linfoma de bajo grado (Figura 42).
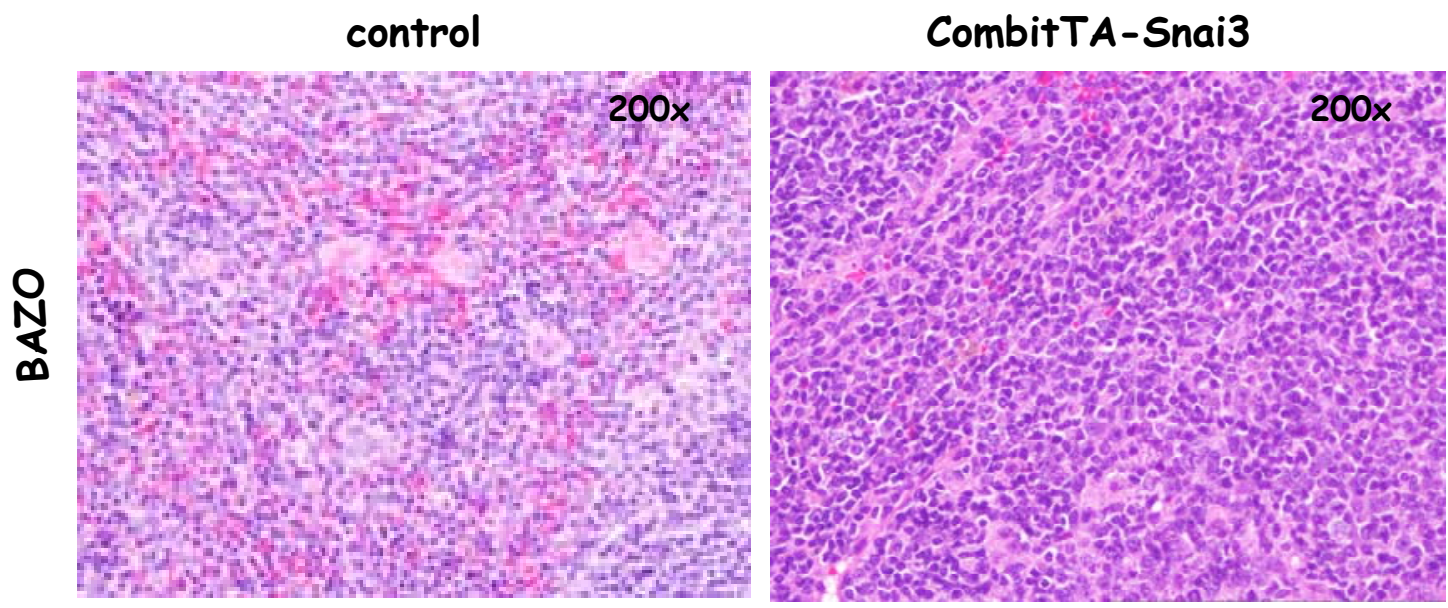

Figura 42: Masa tumoral de un linfoma de bajo grado en el bazo. Tinción hematoxilina-eosina de cortes histológicos de bazo (aumento 200x) donde se observa infiltración tumoral en el tejido.

En conjunto estos resultados forman una base sólida que apoyan la hipótesis de que la expresión constitutiva de Snai3, al igual que los otros miembros de la familia, Snai1 y Snai2, está implicada en el desarrollo de ciertos tipos de cánceres.

\subsection{Snai3 acelera el desarrollo de tumores en ratones $153^{-/-}$}

Nuestros ratones transgénicos CombitTA-Snai3 son un sistema óptimo para el estudio de la tumorogénesis en un fondo genético $p 53^{-/}$, ya que nuestro transgén es regulado por 
la doxiciclina y no por p53 como sucedería en condiciones endógenas. En este sentido procedimos a generar ratones CombitTA-Snai3 en un fondo genético p53 $3^{-/}$(CombitTASnai3;p53 $3^{-/}$), como hemos explicado anteriormente.

Todos los ratones generados fueron normales al nacimiento, y presentaron un desarrollo normal. Con el paso del tiempo observamos que la vida media de los CombitTA-Snai3 $p 53^{-/-}$era de 4 meses (Figura 43), una vida media un poco más corta que los ratones $p 53^{-/}$del laboratorio del Dr. Tyler Jacks (vida media de aprox 4,5 meses) (Jacks et al., 1994).

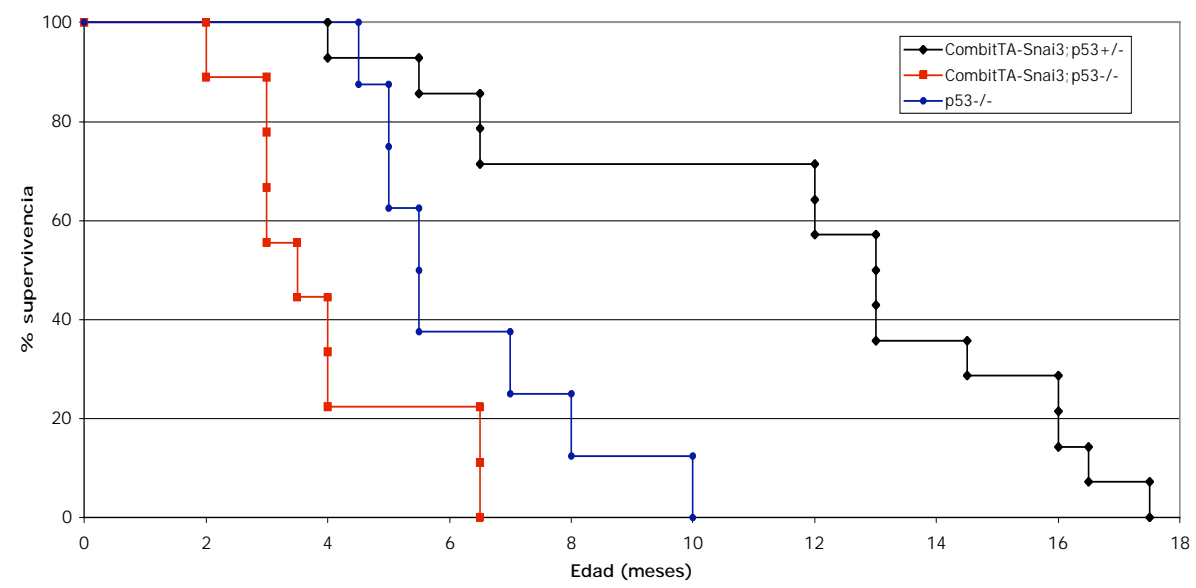

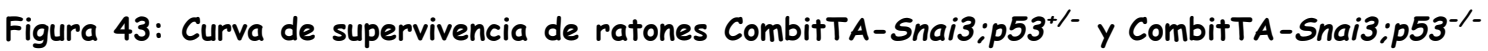

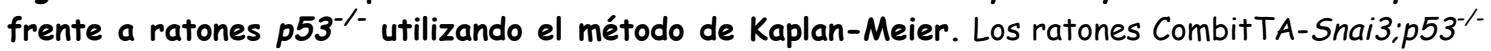
tienen una vida media de 4 meses frente a los 5,5 meses de los ratones $p 53^{\%}$. Los ratones CombitTA-Snai3; $53^{+/-}$tienen una vida media mucho mayor.

Para confirmar que esa menor supervivencia era debida a la expresión de Snai3 y no a una menor supervivencia asociada a las condiciones de cría de los ratones, generamos también una curva de supervivencia con ratones $p 53^{-/-}$mantenidos en nuestro laboratorio. Como se observa en la Figura 43, la supervivencia de los ratones $p 53^{-/-}$en nuestro animalario era un poco superior (vida media de aprox 5,5 meses) a la descrita previamente. Esta diferencia observada en la vida media de nuestros ratones $p 53^{-/-}$con respecto a la previamente descrita (Jacks et al., 1994), probablemente sea debida al fondo genético en que han sido generados los ratones. Así, aunque la estrategia utilizada para generar los ratones $p 53^{-/-}$es la misma en ambos casos, los ratones del laboratorio del Dr. Tyler Jacks se encuentran en un fondo genético C57BL/6, mientras que los 
nuestros se han generado en un fondo genético C57BL/6xCBA, que es el mismo fondo genético en que se han generados los ratones CombitTA-Snai3.

Los tumores desarrollados en los ratones $p 53^{-/-}$eran en la mayoría de los casos (70\%) linfomas que generalmente afectaron al timo (Jacks et al., 1994). En el 30\% restante de los tumores observados en ratones $p 53^{-/}$se incluían: osteosarcoma, rabdomiosarcoma, hemangiosarcoma y teratoma (Jacks et al., 1994).

El 78\% de los ratones CombitTA-Snai3;p53 $3^{-/}$morían a los 4 meses de edad y, en aprox el 77,7\% de los ratones analizados, se pudo evidenciar la presencia de linfomas mucho más agresivos e invasivos que los de los $p 53^{-/-}$o sarcomas de alto grado (Figura $44+$ Tabla 2).

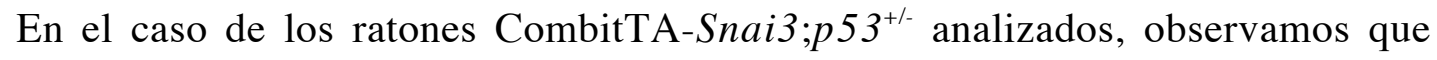
también se producía una muerte más temprana por el desarrollo de linfomas muy agresivos o sarcomas de alto grado (Figura $44+$ Tabla 2).
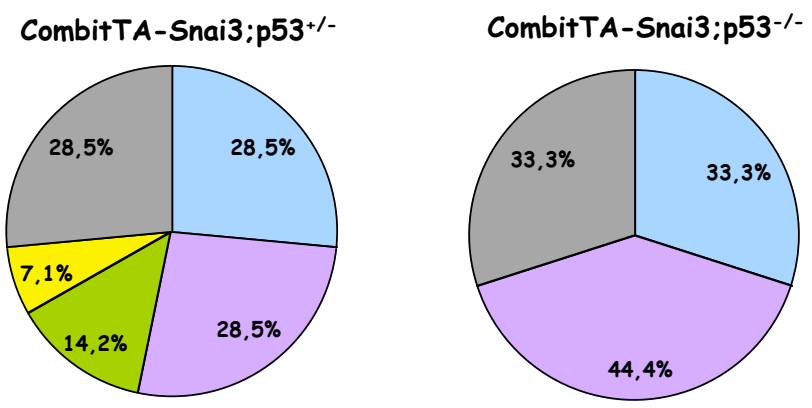

$\square$ LINFOMA LINFOBLÁSTICO AGRESIVO

$\square$ SARCOMA DE ALTO GRADO

TUMOR INDETERMINADO

CARCINOMA

OTRAS CAUSAS (SIN TUMOR)

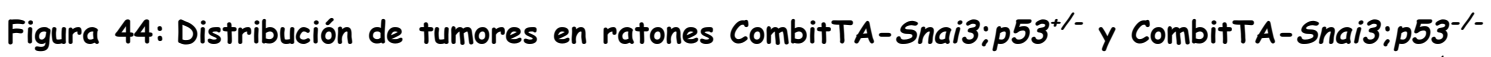
- Frecuencias relativas de los tipos de tumores observados en ratones CombitTA-Snai3:p53 ${ }^{+/-}$y CombitTA-Snai3; $53^{-1-}$. Como se observa en la figura, se desarrollan con gran frecuencia Linfomas linfoblástico agresivo y Sarcomas de alto grado.

En la mayoría de los tumores desarrollados en los ratones $p 53^{+/-}$del laboratorio del Dr. Tyler Jacks se produjo la pérdida del alelo restante de $p 53^{-/}$, que generalmente ocurrió mediante mecanismos a nivel cromosómico. Este fenómeno también lo observamos en los tumores desarrollados en dos de los ratones CombitTA-Snai3;p53 ${ }^{+/-}$ (Tabla 2). Esto pone de manifiesto la pérdida de función de p53 durante el desarrollo de tumores, lo cual apoyaría una importante función de Snai3 en la tumorogénesis. 


\begin{tabular}{|c|c|c|c|c|}
\hline Genotipo p53 & CombitTA-Snai3 & Genotipo tumor p53 & Edad & Histología \\
\hline $\mathrm{KO}$ & + & KO & 2 meses & SARCOMA DE ALTO GRADO \\
\hline KO & + & KO & 3 meses & \\
\hline KO & + & KO & 3 meses & LINFOMA LINFOBLÁSTICO AGRESIVO, SARCOMA \\
\hline KO & + & KO & 3 meses & \\
\hline KO & + & $\mathrm{KO}$ & 3,5 meses & LINFOMA LINFOBLÁSTICO AGRESIVO \\
\hline KO & + & KO & 4 meses & SARCOMA DE ALTO GRADO \\
\hline KO & + & KO & 4 meses & LINFOMA LINFOBLÁSTICO AGRESIVO \\
\hline KO & + & $\mathrm{KO}$ & 6,5 meses & SARCOMA DE ALTO GRADO \\
\hline KO & + & KO & 6,5 meses & \\
\hline Heterozigótico & + & $\mathrm{KO}$ & 4 meses & LINFOMA LINFOBLÁSTICO AGRESIVO \\
\hline Heterozigótico & + & KO & 5,5 meses & LINFOMA EN BAZO \\
\hline Heterozigótico & + & Heterozigótico & 6,5 meses & LINFOMA LINFOBLÁSTICO AGRESIVO \\
\hline Heterozigótico & + & Heterozigótico & 6,5 meses & \\
\hline Heterozigótico & + & Heterozigótico & 12 meses & SARCOMA MIELOIDE, OSTEOBLASTOMA \\
\hline Heterozigótico & + & Heterozigótico & 12 meses & ADENOCARCINOMA, TUMOR EPITELIAL DE ALTO GRADO \\
\hline Heterozigótico & + & Heterozigótico & 13 meses & TUMOR AXILIAR \\
\hline Heterozigótico & + & Heterozigótico & 13 meses & \\
\hline Heterozigótico & + & Heterozigótico & 13 meses & \\
\hline Heterozigótico & + & Heterozigótico & 14,5 meses & SARCOMA \\
\hline Heterozigótico & + & Heterozigótico & 16 meses & SARCOMA DE GRADO ALTO \\
\hline Heterozigótico & + & Heterozigótico & 16 meses & \\
\hline Heterozigótico & + & Heterozigótico & 16,5 meses & \\
\hline Heterozigótico & + & Heterozigótico & 17,5 meses & SARCOMA, TUMOR LINFOIDE \\
\hline
\end{tabular}

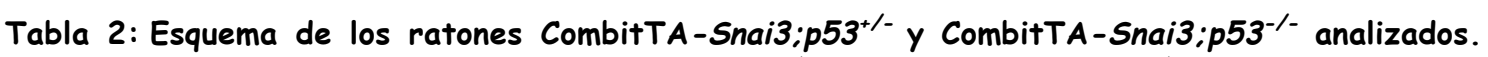

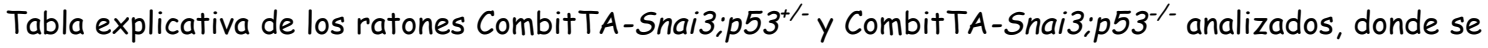
especifica el genotipo de cada ratón, la edad a la que fueron analizados, la histología de los tumores hallados y si existe un cambio de genotipo del tumor para p53. En el caso de los ratones CombitTASnai3: $\mathrm{p} 3^{+/-}$nos encontramos con dos tumores en los que se había producido un cambio de genotipo en el tumor para $p 53$, de manera que iban a ser CombitTA-Snai3:p53/-. y en los dos casos se trataba de un linfoma.

El estudio anatomo-patológico de los tumores hallados en tres de los nueve ratones CombitTA-Snai3;p53/- y en cuatro de los catorce ratones CombitTASnai3;p53 $3^{+/-}$analizados, reveló que los tumores se correspondían con un linfoma linfoblástico agresivo (Tabla 2 y Figura 45+46). Se trataba de un tumor de naturaleza hematológica que afectaba al timo, y que infiltraba diversos tejidos, como son pulmón, corazón, bazo, hígado, páncreas, bazo y riñón (Figura 45+46). En todos esos órganos se apreciaron áreas bien definidas de células tumorales que estaban invadiendo totalmente el tejido normal. 

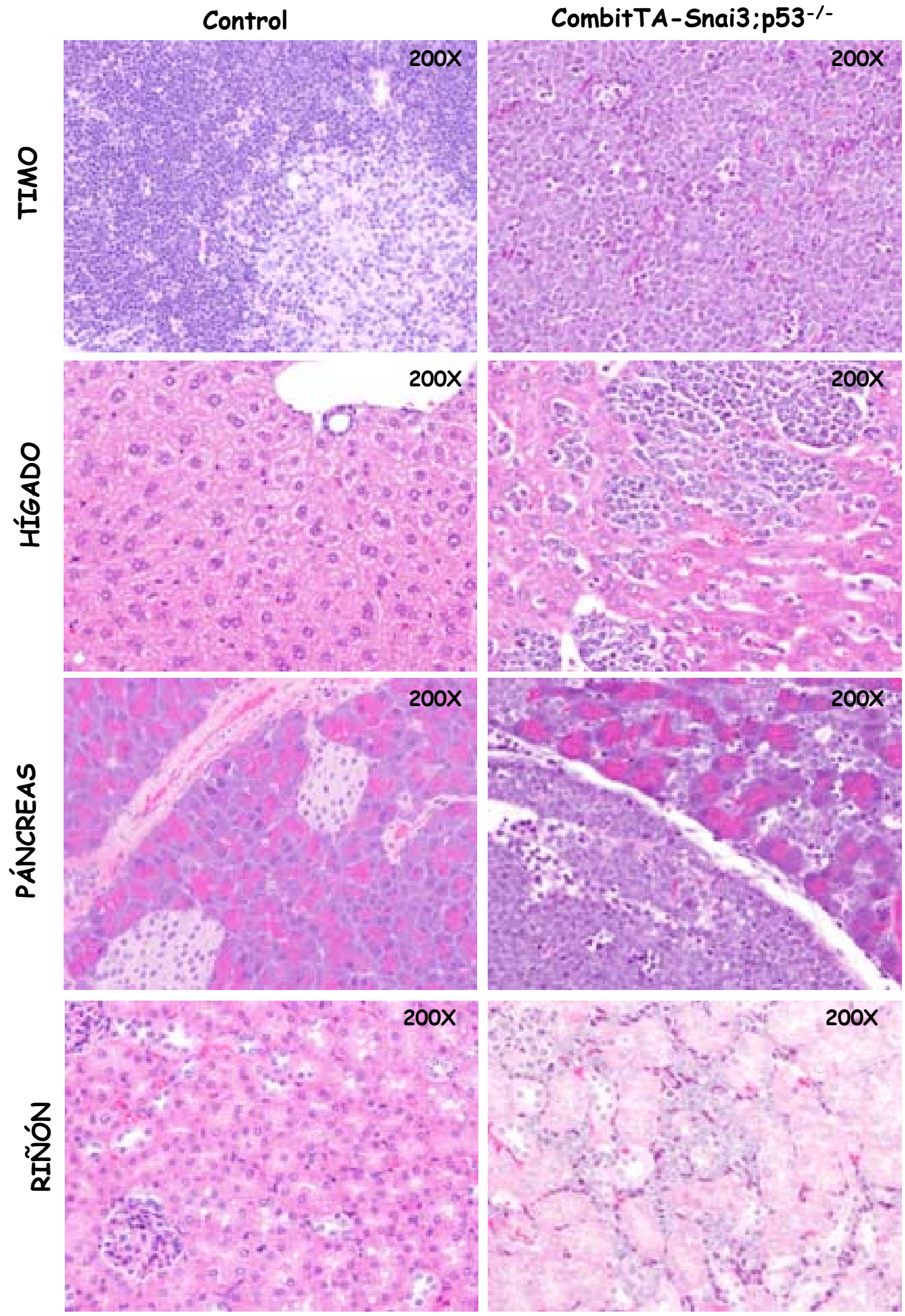

Figura 45: Linfoma tímico muy agresivo que infiltra diferentes tejidos. Tinción hematoxilinaeosina de cortes histológicos de timo (aumento 200x), hígado (aumento 200x), páncreas (aumento 200x), y riñón (aumento 200x) donde se observa infiltración tumoral en el tejido. 


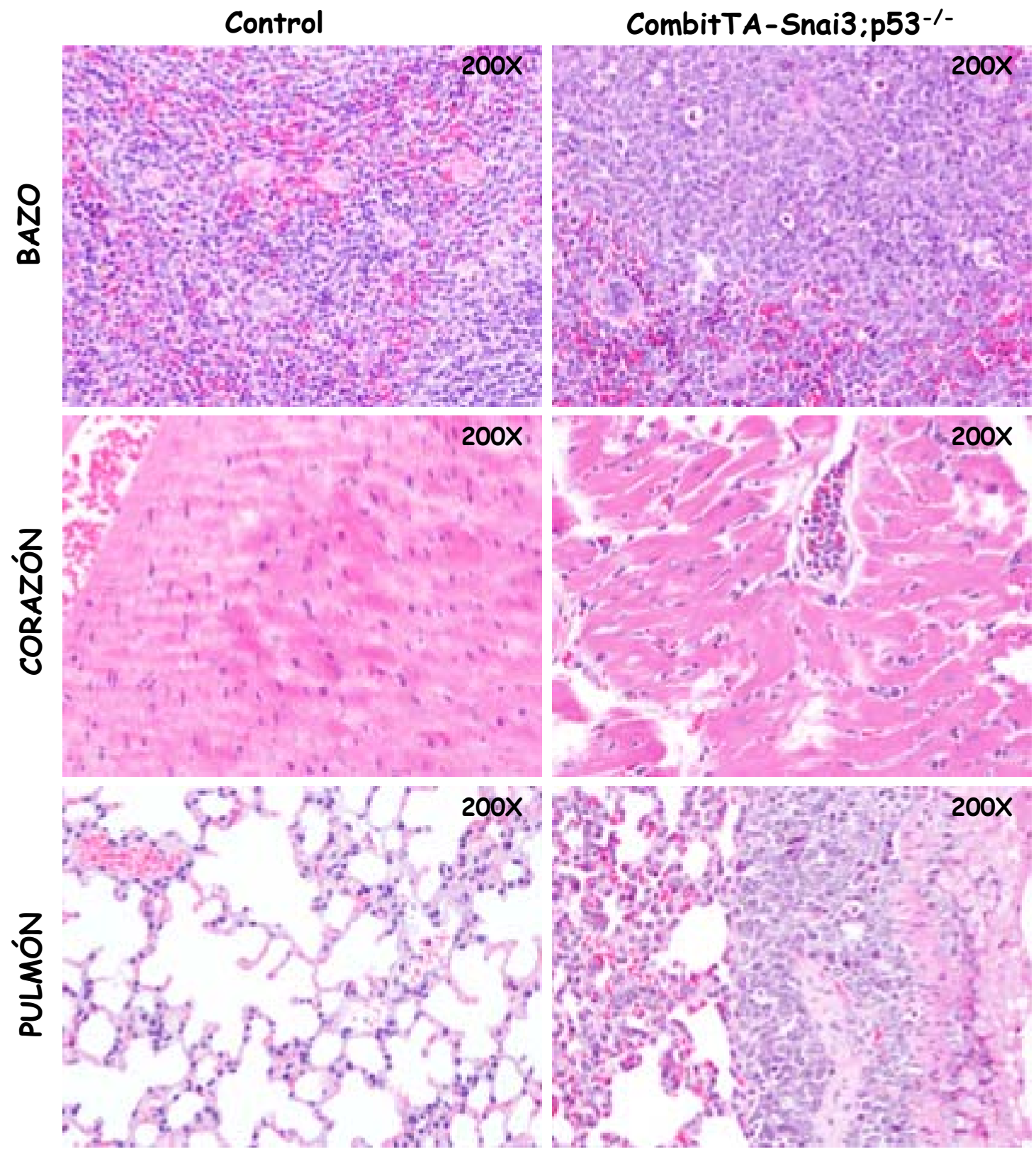

Figura 46: Linfoma tímico muy agresivo que infiltra diferentes tejidos. Tinción hematoxilinaeosina de cortes histológicos de bazo (aumento 200x), corazón (aumento 200x), y pulmón (aumento 200x), donde se observa infiltración tumoral en el tejido.

Todos estos datos ponen de manifiesto que la expresión de Snai3 favorece la formación de la masa tumoral y acelera el desarrollo de tumores que se producen en ausencia de p53. Además la expresión constitutiva in vivo de Snai3 parece aumentar la capacidad invasiva y migratoria de las células tumorales. Además, suprimiendo la expresión exógena de Snai3 mediante la adición de doxiciclina en el agua de los biberones de los ratones en el momento en que se detectaba del tumor, observamos que no se conseguía la reversión del fenotipo maligno. Esto indicaría que las alteraciones 
inducidas por Snai3 son irreversibles y una vez desarrollado el tumor se vuelve independiente de la expresión de Snai3, como ya había sido observado previamente en los ratones CombitTA-Snai1 y CombitTA-Snai2 (Perez-Mancera et al., 2005a; PerezMancera et al., 2005b).

\section{Regulación entre los miembros de la familia Snail}

\subsection{Regulación transcripcional entre los miembros Snai3 y Snai2 de la familia Snail}

Como hemos comentado previamente, Snai3 debido a su estructura proteica con 5 dedos de zinc se parece más a Snai2 que a Snai1.

A lo largo de la presentación de los resultados, hemos visto que Snai3, al igual que los otros dos miembros de la familia, Snai1 y Snai2, está regulado tras daño en el DNA. Sin embargo, al contrario que Snai1 y Snai2, la expresión transcripcional de Snai3 aumenta tras el tratamiento con doxorrubicina. Y de hecho, esta inducción transcripcional va a ser dependiente de p53, por lo cual Snai3 se parece de nuevo más a Snai2 que a Snai1.

La observación del descenso en la expresión proteica de p21 en las células MEFs control infectadas con Snai3 (sin y con daño) (Figura 33) nos llamó la atención, ya que la expresión de la proteína p21 también se ve disminuida en las células MEFs Snai2 ${ }^{-/}$ (Bermejo-Rodriguez et al., 2006).

El hecho de que la expresión de Snai3 esté regulada de manera dependiente de p53, pero de forma opuesta a la de Snai2 en células MEFs control tras el tratamiento provocado con doxorrubicina, nos hizo pensar en una posible regulación entre ambos miembros. Por ello, quisimos estudiar la expresión de Snai2 en el contexto celular de las células $\mathrm{Ba} / \mathrm{F} 3$ tras la retirada de IL-3, para ver si en este contexto se mantiene esa misma regulación opuesta. En el contexto celular de las Ba/F3 habíamos observado la inducción de la expresión de Snai3 tras la retirada de la IL-3 (Figura 17B), al igual que en los MEFs control tras el tratamiento con doxorrubicina (Figura 18A+B). En la Figura 47A podemos observar que la expresión de Snai2 disminuye tras la retirada de la IL-3, lo cual nos muestra nuevamente una regulación opuesta a la de Snai3, apoyando nuestra hipótesis inicial.

Dado que los miembros de la familia Snail actúan como represores transcripcionales (Batlle et al., 2000; Cano et al., 2000; Hemavathy et al., 2000a), 
aunque en algunas situaciones pueden ser activadores de la transcripción (BermejoRodriguez et al., 2006; Hemavathy et al., 2000b), sería más lógico pensar que Snai2 regula la expresión de Snai3, ya que la expresión de Snai3 aumenta cuando disminuye la expresión de Snai2. Debido a este hecho y a que no tenemos MEFs Snai3 ${ }^{-/}$quisimos estudiar si Snai2 podría estar reprimiendo la expresión de Snai3.

Para hacernos una idea de si Snai2 podría estar regulando la expresión transcripcional de Snai3 hicimos uso de los microarrays de Affymetrix que previamente han sido realizados en el laboratorio con células MEFs control y MEFs Snai2 ${ }^{-/}$ cultivadas en ausencia o presencia de doxorrubicina. Como se observa en la Figura 47B la expresión de Snai3 aumenta en los MEFs control tras el tratamiento con doxorrubicina cuando se compara con la expresión de Snai3 en los MEFs control sin daño, lo que coincide con nuestro resultado observado anteriormente en la Figura 18B. También observamos en la Figura 47B que la expresión de Snai3 en los MEFs Snai2 ${ }^{-{ }^{-}}$es mayor que la observada en los MEFs control. Por lo tanto, estos datos sugieren que Snai2 podría estar regulando la expresión de Snai3.

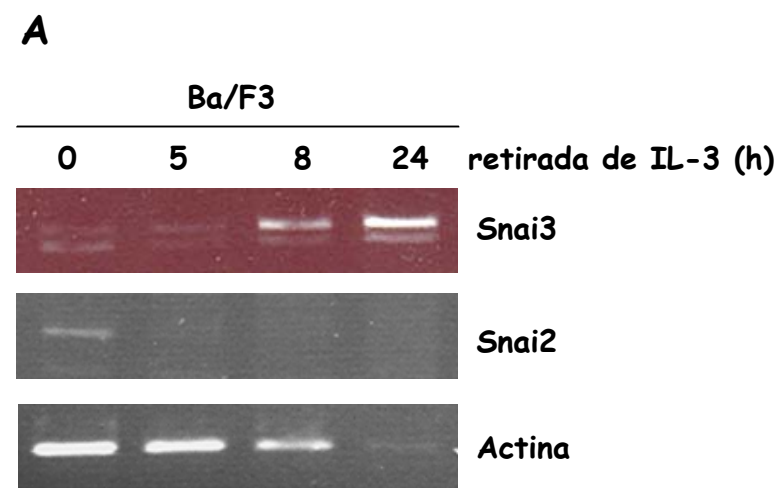

B

\begin{tabular}{|c|c|c|c|c|}
\hline & $\begin{array}{c}\text { MEFs control + Dox }(12 h) \\
\text { vs } \\
\text { MEFs control }\end{array}$ & $\begin{array}{c}\text { MEFs Snai2-1- } \\
\text { vs } \\
\text { MEFs control }\end{array}$ & $\begin{array}{c}\text { MEFs Snai2 }-/-+ \text { Dox }(12 h) \\
\text { vs } \\
\text { MEFs control }+ \text { Dox }(12 h)\end{array}$ & $\begin{array}{c}\text { MEFs Snai2 }-/-+ \text { Dox (12h) } \\
\text { vs } \\
\text { MEFs Snai2-/- }\end{array}$ \\
\hline Snai3 & 73,21023333 & 12,59083767 & 1,781865195 & 10,36076948 \\
\hline
\end{tabular}

Figura 47: Análisis de la regulación transcripcional de Snai3 y Snai2. (A) Análisis de la expresión de Snai3 y Snai2 en células Ba/F3 tras la retirada de IL-3 durante 0, 5, 8 y 24 horas mediante RTPCR. Como control de carga utilizamos actina. (B) Análisis de la expresión transcripcional de Snai3 en células MEFs control y MEFs Snai2 ${ }^{-/-}$en ausencia o presencia de doxorrubicina (12 horas; 0,2 $\mu \mathrm{g} / \mathrm{ml}$ ) mediante microarrays de Affymetrix. El valor rojo indica que cuando se compara la expresión en los dos tipos celulares en cuestión existe una sobre-expresión de ese gen en el primero con respecto al segundo tipo celular. 


\subsection{La expresión de Snai3 aumenta en ausencia de Snai2}

Para confirmar esta posible regulación entre Snai2 y Snai3 utilizamos MEFs control y MEFs Snai2 ${ }^{-/}$, y analizamos a nivel de RNA el nivel de expresión de Snai3 en estas células.

Para ello, extrajimos RNA total de los tipos celulares MEFs control y MEFs Snai2 $^{--}$, y analizamos la expresión transcripcional de Snai3 en estas células mediante RT-PCR semicuantitativa haciendo diluciones 1/5 y 1/25 a partir del cDNA sin diluir.

Como se puede observar en la Figura 48, la expresión transcripcional de Snai3 aumenta en los MEFs Snai2 ${ }^{-/}$cuando se compara con el nivel de expresión en los MEFs control. Así pues, parece que Snai2 reprime la expresión de Snai3, ya que en células MEFs sin Snai2 la ausencia de la misma hace que se induzca la expresión de Snai3.

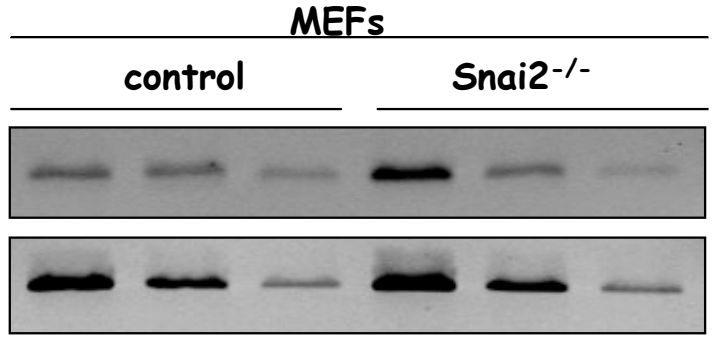

Figura 48: Análisis de la expresión de Snai3 en ausencia de Snai2. Estudio de la expresión transcripcional de Snai3 en los MEFs control y MEFs Snai2 ${ }^{-/-}$mediante RT-PCR semicuantitativa haciendo diluciones $1 / 5$ y $1 / 25$ a partir del cDNA sin diluir. GAPDH Como control de carga utilizamos GAPDH.

Por tanto en los MEFs Snai2 ${ }^{-/}$tras daño en el DNA esperaríamos obtener el mismo nivel de Snai3 como en ausencia de daño. Sin embargo, los datos obtenidos en los arrays parecen indicar que existe un aumento en la expresión de Snai3 tras daño en el DNA en ausencia de Snai2, que nos indicaría la existencia de mecanismos de regulación de Snai3 independientes de Snai2. Para comprobar si esto es así, quisimos analizar mediante RT-PCR semicuantitativa el nivel de Snai3 en los MEFs Snai2 ${ }^{-/}$tras daño en el DNA.

Tratamos entonces células MEFs control y células MEFs Snai2 ${ }^{-/}$sin y con doxorrubicina durante 24 horas, y analizamos la expresión de Snai3 en estas células a nivel de RNA mediante RT-PCR semicuantitativa de cDNAs haciendo diluciones de 1/5 y 1/25 a partir del cDNA sin diluir, como en experimentos anteriores.

En la Figura 49A observamos que existe un aumento en la expresión de Snai3 en los MEFs Snai2 ${ }^{--}$tras el tratamiento con doxorrubicina, que nos confirma el dato 
observado en los microarrays, de la existencia de los mecanismos independientes de Snai2 en la regulación de Snai3.

También observamos un aumento en la expresión de Snai3 en los MEFs Snai2 ${ }^{-/-}$ tras el tratamiento con doxorrubicina cuando se compara con los MEFs control también tras el tratamiento con doxorrubicina, que se observa mejor en las diluciones $1 / 5$ y 1/25 del cDNA, ya que la expresión de Snai3 está elevada en la muestra del cDNA sin diluir, no detectándose diferencias. Por ello, repetimos el análisis de la expresión de Snai3 mediante RT-PCR semicuantitava disminuyendo el número de ciclos para poder observar mejor las diferencias en el nivel de la expresión de Snai3. Como podemos observar en la Figura 49B se ve claramente una mayor expresión de Snai3 en los MEFs Snai2 $^{-/}$(en todos los pocillos) tras el tratamiento con doxorrubicina cuando se compara con los MEFs control, también tratados con doxorrubicina, que se podría explicar por el hecho de que los MEFs control tras daño en el DNA siguen teniendo un cierto nivel de expresión de Snai2.

A

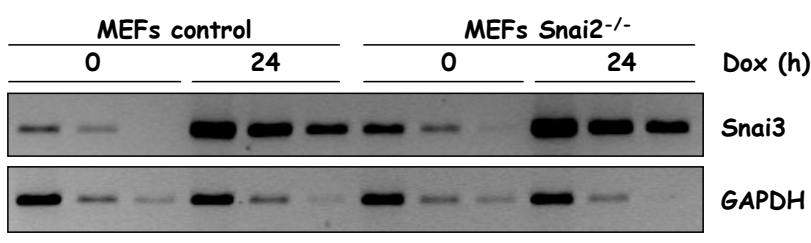

B

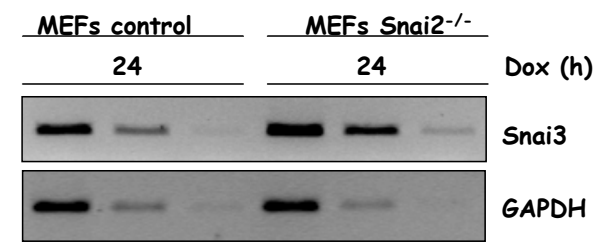

C

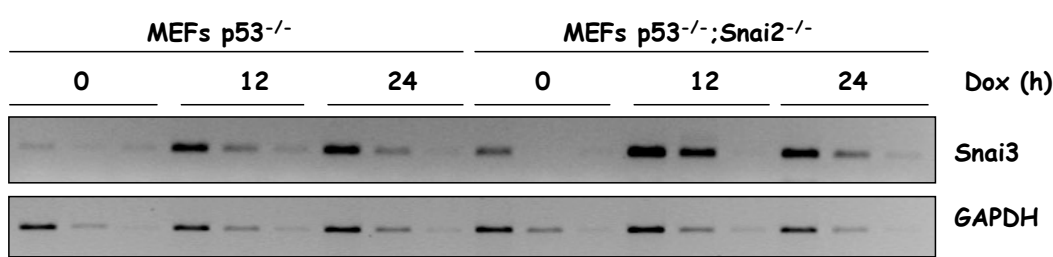

Figura 49: Análisis de la expresión transcripcional de Snai3 en células MEFs sin Snai2. Análisis de la expresión de Snai3 mediante RT-PCR semicuantitativa de CDNA de diferentes tipos de los MEFs haciendo diluciones $1 / 5$ y $1 / 25$ a partir del CDNA sin diluir. (A) MEFs control y MEFs Snai ${ }^{-1-}$ tratados 24 horas $\sin$ y con doxorrubicina $(0,2 \mu \mathrm{g} / \mathrm{ml})$. (B) MEFs control y MEFs $\mathrm{p} 53^{-/-}$tratados 24 horas con doxorrubicina y analizados en menos ciclos de RT-PCR semicuantitativa. (C) MEFs $p 53^{-1-}$ y MEFs $\mathrm{p} 53^{-/} ;$:Snai2 $2^{--}$tratados $\sin$ y con doxorrubicina (12 y 24 horas). Como control de carga fue utilizado GAPDH.

Como ya hemos comentado, los MEFs p53 ${ }^{-/-}$tienen un menor nivel de expresión de Snai3 tras daño en el DNA cuando se compara con los MEFs control también 
tratados con doxorrubicina, y sabemos por datos observados en nuestro laboratorio (aún no publicados) que el nivel de Snai2 no varía tras el daño en el DNA en los MEFs p53 ${ }^{-/}$. Por ello, quisimos estudiar la implicación de Snai2 en la regulación de expresión de Snai3 en los MEFs sin p53. Para realizar este estudio utilizamos MEFs p53 ${ }^{-/}$y MEFs p5 $3^{--}$;Snai $2^{-/-}$tratados sin y con doxorrubicina durante 12 y 24 horas, y analizamos la expresión de Snai3 en estas células a nivel de RNA mediante RT-PCR como en experimentos anteriores (Figura 49C). Observamos que la expresión de Snai3 es mayor en los MEFs p53 $3^{-/-}$;Snai $2^{-/}$, tanto sin doxorrubicina como con doxorrubicina, cuando se compara con la expresión de Snai3 en los MEFs p53 $3^{--}$. Por tanto, otra vez más se ve que la ausencia de Snai2 induce la expresión de Snai3. De esta manera, podemos concluir con nuestros resultados obtenidos en diferentes tipos de MEFs que Snai2 parece regular negativamente la expresión de Snai3.

Como en experimentos anteriores comprobamos la inducción del daño mediante la expresión de p53 y p21 mediante Western Blot, y también el genotipo de los MEFs Snai2 $^{-{ }^{--}}$(Figura 50A) y de los MEFs p53 $3^{--} ;$Snai2 $^{-{ }^{--}}$(Figura 5OB).

A

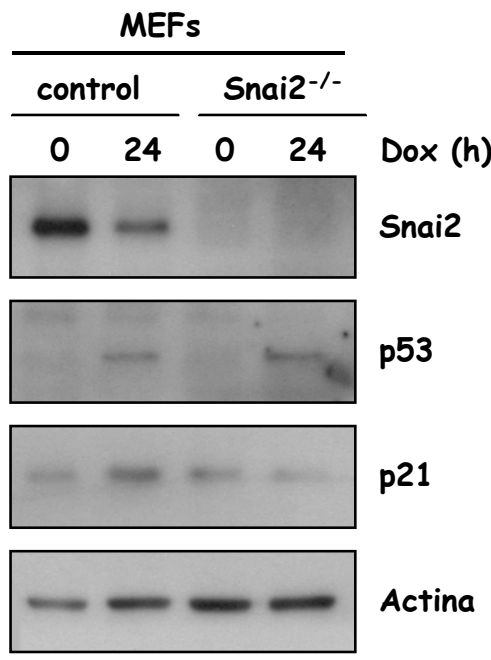

B

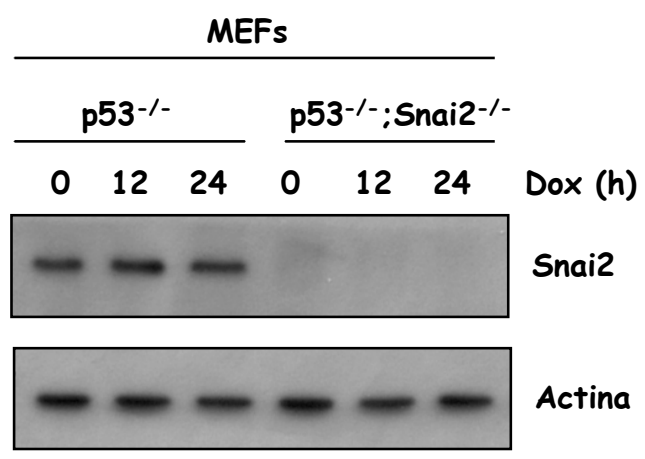

Figura 50: Comprobación de la inducción del daño y del genotipo de los MEFs utilizados. (A) Análisis de la inducción del daño en los MEFs control y MEFs Snai2 ${ }^{-1-}$ tras el tratamiento con doxorrubicina $(0,2 \mathrm{\mu g} / \mathrm{ml})$ durante 24 horas mediante Western Blot con anticuerpos frente a p53 y p21. El genotipo de los MEFs Snai2 ${ }^{-1-}$ lo comprobamos con un anticuerpo frente a Snai2. La actina fue utilizada como control de carga. (B) Comprobación del genotipo de los MEFs en relación con Snai2 mediante Western Blot con un anticuerpo frente a Snai2. La actina confirma una carga similar en todas las muestras. 


\subsection{La expresión exógena de Snai2 modifica la expresión de Snai3 en distintos tipos de MEFs}

A continuación quisimos saber si la introducción de Snai2 en las mismas células utilizadas en los experimientos anteriores modifica la expresión de Snai3, la cual se induce en ausencia de Snai2 en diferentes tipos de MEFs, como son los MEFs Snai2 ${ }^{-/}$y los MEFs p53 $3^{-/} ;$Snai2 $2^{--}$( $\sin$ y con daño).

Para ello, infectamos células MEFs control, MEFs $553^{-/-}$, MEFs Snai2 ${ }^{-/-}$y MEFs ${\mathrm{p} 53^{-/} ; \text {Snai2 }}^{-/}$con Snai2. En esta ocasión utilizamos como vector retroviral el pBabePuro, en el cual clonamos el cDNA de Snai2, que nos va a permitir obtener un nivel de expresión de Snai2 más fisiológico.

En primer lugar, estudiamos el efecto de la introducción de Snai2 en la expresión de Snai3 en células MEFs control y MEFs $\mathrm{p} 53^{-/-}$tratadas $\sin$ y con doxorrubicina durante 12 y 24 horas. Para ello, analizamos la expresión de Snai3 mediante RT-PCR semicuantitativa, como en estudios anteriores.

Como podemos observar en la Figura 51A en ausencia de daño al DNA no existen diferencias en la expresión de Snai3 de las células MEFs control Mock y Snai2. Sin embargo, en presencia del daño en el DNA se aprecia un ligero descenso en la expresión de Snai3 en las células MEFs control infectadas con Snai2 cuando se compara con las células infectadas con el retrovirus vacío. Esto coincide con el resultado observado en el Western Blot (Figura 51B), donde se observa que en ausencia de daño apenas hay diferencias en el nivel de expresión de Snai2 entre los MEFs infectados con el retrovirus vacío y los MEFs infectados con Snai2, pero en presencia de daño el nivel de Snai2 es mayor en los MEFs infectados con Snai2.

En el caso de los MEFs p53 ${ }^{-/}$infectados con el retrovirus vacío o con Snai2 no se observan diferencias en el nivel de expresión de Snai3, ni en ausencia ni en presencia de daño en el DNA. Esto también coincidería con el resultado observado en el Western Blot (Figura 51B), donde no se aprecian diferencias en la expresión de Snai2 entre las células infectadas con el retrovirus vacío y con Snai2. 
A

\begin{tabular}{|c|c|c|c|c|c|c|c|c|c|c|c|c|}
\hline \multicolumn{6}{|c|}{ MEFs control } & \multicolumn{6}{|c|}{ MEFs p 53-/- } & \\
\hline \multicolumn{3}{|c|}{ Mock } & \multicolumn{3}{|c|}{ Snai2 } & \multicolumn{3}{|c|}{ Mock } & \multicolumn{3}{|c|}{ Snai2 } & \multirow[b]{2}{*}{ Dox (h) } \\
\hline 0 & 12 & 24 & 0 & 12 & 24 & 0 & 12 & 24 & 0 & 12 & 24 & \\
\hline-1 & - & - & & - & -- & - & $-=$ & - & & -- & $-=$ & Snai3 \\
\hline- & -- & $=$ & - & -2 & - & - & $-\infty$ & - & & $-\infty$ & -- & GAPDH \\
\hline
\end{tabular}

B

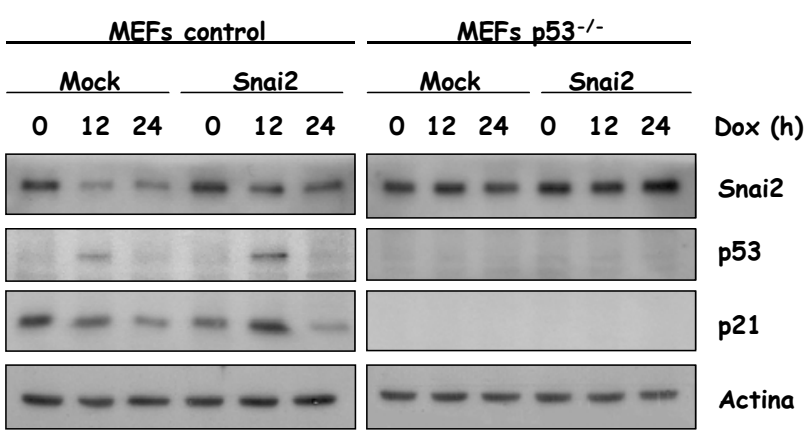

Figura 51: Análisis de la expresión transcripcional de Snai3 en células MEFs en las que expresamos Snaiz exógenamente y comprobación de la inducción de daño y la eficiencia de la infección. (A) Analizamos la expresión de Snai3 mediante RT-PCR semicuantitativa en CDNAs de MEFs control y MEFs $\mathrm{p} 53^{-1-}$ tratadas sin y con doxorrubicina $(0,2 \mathrm{\mu g} / \mathrm{ml})$ durante 12 y 24 horas e infectadas con el retrovirus vacío (Mock) o con Snai2 haciendo diluciones $1 / 5$ y $1 / 25$ a partir del CDNA sin diluir. Como control de carga fue utilizado GAPDH. (B) Análisis de la inducción del daño en los MEFs control y MEFs $\mathrm{p} 53^{-/}$infectados con el retrovirus vacío o con Snai2 tras el tratamiento con doxorrubicina $(0,2 \mu \mathrm{g} / \mathrm{ml})$ durante 12 y 24 horas mediante Western Blot con anticuerpos frente a $\mathrm{p} 53$ y p21. La eficiencia de la infección con Snai2 la comprobamos con el anticuerpo frente a Snai2. La actina fue utilizada como control de carga.

A continuación, estudiamos el efecto de la expresión exógena de Snai2 en la expresión de Snai3 en los MEFs Snai2 ${ }^{-/-}$(Figura 52A). Como hemos observado en la Figura 48 el nivel de expresión de Snai3 en las células sin Snai2 es mayor que en los MEFs control. Por lo tanto, sería lógico pensar que la reintroducción de Snai2 en los MEFs Snai2 ${ }^{-/}$nos permitiría recuperar el nivel de expresión de Snai3 observado en los MEFs control. Sin embargo, como se observa en la Figura 52A no se observan diferencias en la expresión de Snai3 en la ausencia o presencia de Snai2.

Por el contrario, cuando analizamos la expresión de Snai3 en los doble knock-out para p53 y Snai2 que expresan Snai2 observamos que la expresión de Snai3 disminuye tras daño en el DNA cuando se compara el nivel de expresión de Snai3 con los MEFs ${\mathrm{p} 53^{-/-} ; \text {Snai2 }}^{-/-}$infectados con el retrovirus vacío (Figura 52B). 
A

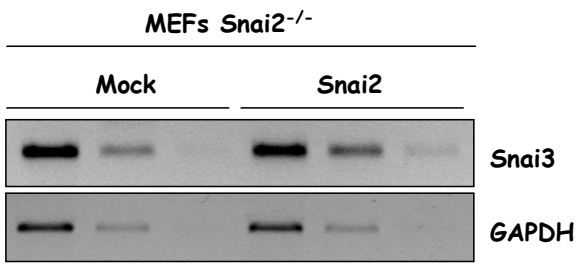

B

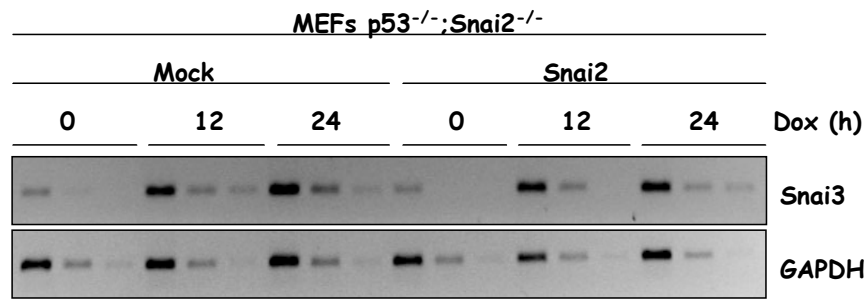

$c$

\begin{tabular}{|c|c|c|c|c|c|}
\hline \multicolumn{6}{|c|}{ MEFs p53-1-:Snai2-/- } \\
\hline \multicolumn{3}{|c|}{ Mock } & \multicolumn{3}{|c|}{ Snai2 } \\
\hline 0 & 12 & 24 & 0 & 12 & 24 \\
\hline & & & $\mathrm{mes}$ & $-\infty$ & $=$ \\
\hline$\infty$ & & & $=$ & $=$ & $=$ \\
\hline
\end{tabular}

Figura 52: Análisis de la expresión transcipcional de Snai3 en células MEFs en las que expresamos Snair exógenamente. Analizamos la expresión de Snai3 mediante RT-PCR semicuantitativa en CDNA de diferentes tipos de MEFs infectados con el retrovirus vacío o con Snai2 haciendo diluciones de $1 / 5$ y $1 / 25$ a partir del CDNA sin diluir. (A) MEFs Snai2 ${ }^{-1-}$, (B) MEFs p53 $3^{-1-}$ :Snai2 ${ }^{-1-}$ tratados $\sin$ y con doxorrubicina $(12$ y 24 horas) $(0,2 \mu \mathrm{g} / \mathrm{ml})$. Como control de carga utilizamos GAPDH. (C) Comprobamos la eficiencia de la infección de las células MEFs p53 $3^{-1-}$; Snai2 $2^{-1-}$ a nivel de proteínas mediante Western Blot con un anticuerpo frente a Snai2. La actina confirma una carga similar en todas las muestras.

Como en experimentos anteriores, analizamos también la expresión de Snai2 a nivel proteico mediante Western Blot para comprobar la eficiencia de la infección de las células (Figura 52C).

Podemos concluir, por tanto, que el aumento en la expresión de Snai2 disminuye el nivel de expresión de Snai3 en diferentes tipos de MEFs.

\subsection{Snai2 reprime el promotor de Snai3}

Para confirmar si Snai3 es una diana transcripcional de Snai2, de manera que Snai2 regula negativamente su expresión, realizamos un estudio de Luciferasa cotransfectando células MEFs con el promotor de Snai3 (pGL3-mSnai3(2783bp)) que hemos utilizado previamente, y con el vector pcDNA3-Snai2. Como control negativo co-transfectamos las células con el promotor de Snai3 y con el vector vacío (pcDNA3). Una vez transfectadas las células, las tratamos con doxorrubicina para activar el promotor de Snai3, ya que hemos observado previamente que Snai3 se induce tras daño en el DNA. Utilizando como referencia la actividad del promotor obtenido con el vector vacío, vamos a saber si Snai2 es capaz de reprimir el promotor de Snai3, puesto que en 
este caso la activación del promotor de Snai3 será menor que la observada en las células transfectadas con el vector vacío.

Como podemos observar en la Figura 53, Snai2 reprime el promotor de Snai3, puesto que disminuye la actividad del promotor en un 50\% aproximadamente cuando se compara con la actividad del promotor en las células transfectadas con el vector vacío.

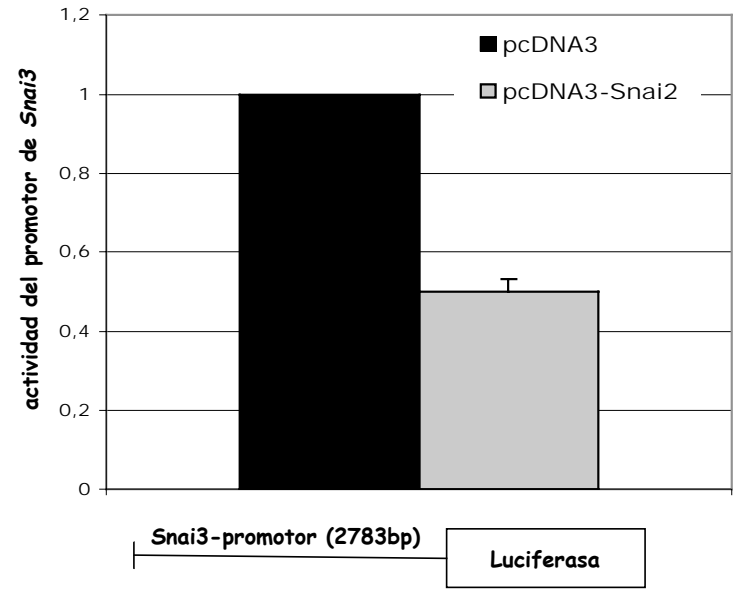

Por lo tanto, podemos concluir que Snai2 reprime el promotor de Snai3, lo cual nos confirma una vez más que Snai2 regula negativamente la expresión de Snai3.

\subsection{Snai3 es una diana directa de Snai2}

Como acabamos de mostrar, Snai2 regula negativamente la transcripción de Snai3, puesto que en ausencia de Snai2 el nivel de transcripción de Snai3 es más elevado (Figura 48) y que Snai2 reprime el promotor de Snai3 (Figura 53). Para determinar si Snai2 regula la transcripción de Snai3 de forma directa o de forma indirecta, analizamos la secuencia del gen Snai3, tanto de humano como de ratón, para ver si existen secuencias E-Box (CANNTG), que son las secuencias de DNA a las que se van a unir los miembros de la familia Snail.

Como podemos ver en la Figura 54, encontramos 2 sitios de unión conservados tanto en humano como en ratón, de los cuales uno se encuentra en el promotor y el otro en el intrón 1. 


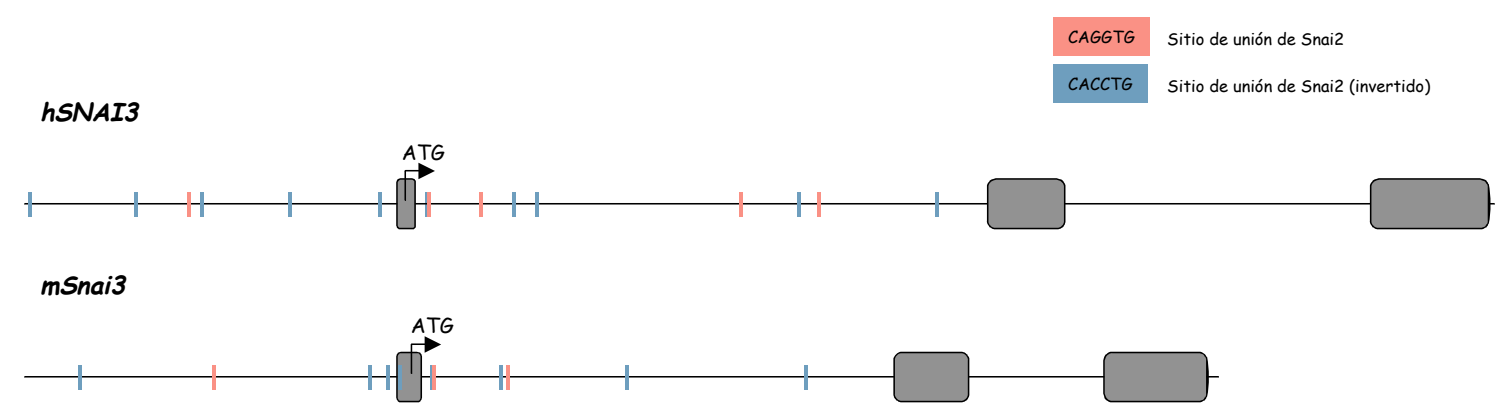

Figura 54: Esquema del gen Snai3 en humano y en ratón. Análisis de la secuencia del gen Snai3 de humano y de ratón, donde aparecen indicadas las secuencias E-Box (CAGGTG en rojo y CACCTG en azul) en este gen. Los sitios de unión conservados en ambas secuencias se encuentran en el promotor y en el intrón 1 del gen Snai3. Los exones están representados mediante cajas en gris.

Para determinar si Snai2 regula la transcripción de Snai3 mediante su unión a una de estas secuencias E-Box (Figura 55A), realizamos el mismo experimento utilizado para el estudio de la unión de p53 a las secuencias RE localizadas en el promotor e intrón 1 de Snai3. Para ello, cultivamos células MEFs control, tanto en ausencia como en presencia de doxorrubicina durante 12 horas, y analizamos la posible regulación directa de Snai3 por Snai2 mediante la inmunoprecipitación de cromatina (ChIP). En este caso, inmunoprecipitamos con un anticuerpo específico para Snai2 para aislar el complejo formado por Snai2 con el DNA.

Como podemos ver en la Figura 55B, en ausencia de daño en el DNA observamos amplificación para la secuencia E-Box que se encuentra en el intrón 1 del gen Snai3, tanto en la muestra Snai2 2 como en la muestra Snai2 3. Sin embargo, en presencia de daño en el DNA provocado por el tratamiento con doxorrubicina, observamos que sólo amplifica la secuencia E-Box que se encuentra en el intrón 1 en la muestra Snai2 3 (Figura 55C). Esto coincide con nuestros resultados obtenidos anteriormente, ya que el nivel de Snai2 es mayor en células MEFs control sin daño en el DNA, por lo cual la probabilidad de unirse a una de estas secuencias E-Box es mayor que en los MEFs control tratados con doxorrubicina. 
A

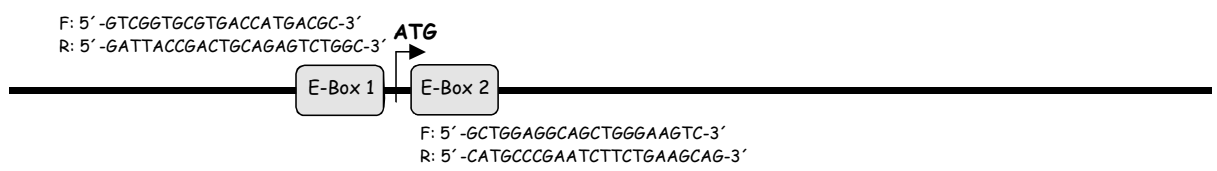

B

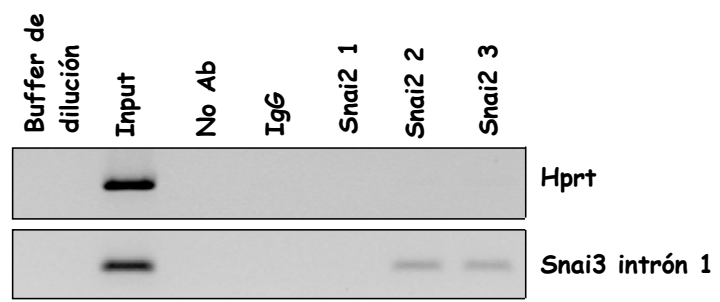

C

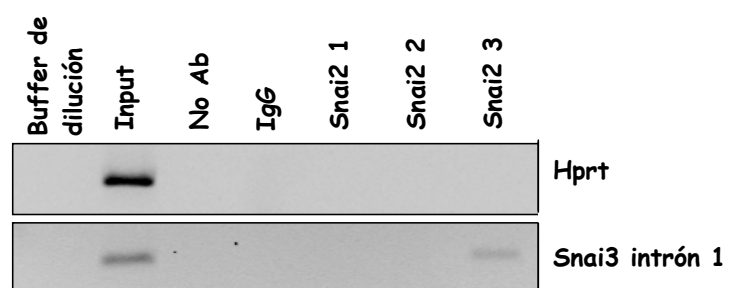

Figura 55: Estudio de la regulación de la transcripción de Snai3 por Snai2 mediante ChIP. (A) Esquema del gen Snai3 con las dos secuencias E-Box encontradas para la unión de Snai2 y los oligos utilizados para su amplificación ( $F=$ Forward; $R=$ Reverse).; Estudiamos mediante el método de la inmunoprecipitación de la cromatina (ChIP) si Snai2 regula la transcripción de Snai3 de forma directa o de forma indirecta en células MEFs control cultivadas en ausencia (B) o en presencia $(C)$ de doxorrubicina. Analizamos la unión de Snai2 a la secuencia E-Box que se encuentra en el intrón 1 del gen Snai3 mediante RT-PCR amplificando las secuencias de interés utilizando oligos específicos. Como control negativo utilizamos Hprt. Utilizamos como muestras MEFs control inmunoprecipitados de la siguiente manera: sin anticuerpo (una muestra), con un anticuerpo inespecífico (muestra $I g G$ ) o con un anticuerpo específico para Snai2 (3 muestras: Snai2 1, 2 y 3). La muestra con Buffer de dilución es el control negativo, ya que no tiene DNA, y la muestra Input es nuestro control positivo puesto que contiene el DNA sin inmunoprecipitar.

Por tanto, podemos concluir que Snai2 regula la expresión de Snai3 de forma directa mediante su unión a la secuencia E-Box situada en el intrón 1 del gen Snai3, y esta unión va a ser mayor en las células MEFs control sin daño, puesto que la expresión de Snai2 disminuye tras daño en el DNA. 
DISCUSIÓN 


\section{Papel de Snai3, un miembro de la familia Snail, en la transición epitelio mesenquimal (EMT)}

La transición epitelio mesenquimal (EMT) es un proceso por el cual las células epiteliales se convierten en células mesenquimales, como hemos explicado anteriormente, lo que implica cambios profundos en la morfología y en el comportamiento de las células epiteliales. Las células epiteliales no sólo pierden el contacto con las células vecinas, sino que también llegan a ser independientes y pueden atravesar la membrana basal que separa diferentes tejidos (Nieto, 2008), y así migrar a sitios lejanos de su origen. Aunque este proceso fue descrito en primer lugar durante el desarrollo embrionario, donde ha descrito ser esencial para la remodelación de tejidos y la migración celular para la formación de un organismo nuevo, también ha demostrado ser importante en situaciones patológicas como es el desarrollo tumoral (Nieto, 2002; Yanez-Mo et al., 2003). En estos contextos celulares se ha visto que los miembros de la familia Snail, Snai1 y Snai2, van a ser estar implicados en la regulación de la expresión de muchas moléculas que participan en la EMT. Los genes de la familia Snail han sido los primeros represores directos descritos en la expresión de la E-caderina (Batlle et al., 2000; Cano et al., 2000), uno de los primeros y más importantes pasos en la inducción de la EMT.

Snai3 es el tercer miembro de la familia Snail en vertebrados, y consta de 5 dedos de zinc y del dominio SNAG a través de las cuales regula la expresión de los genes dianas mediante la unión a secuencias E-Box, y cumple todos los requisitos para ser también un factor de transcripción dentro de la familia Snail (Figura 56).

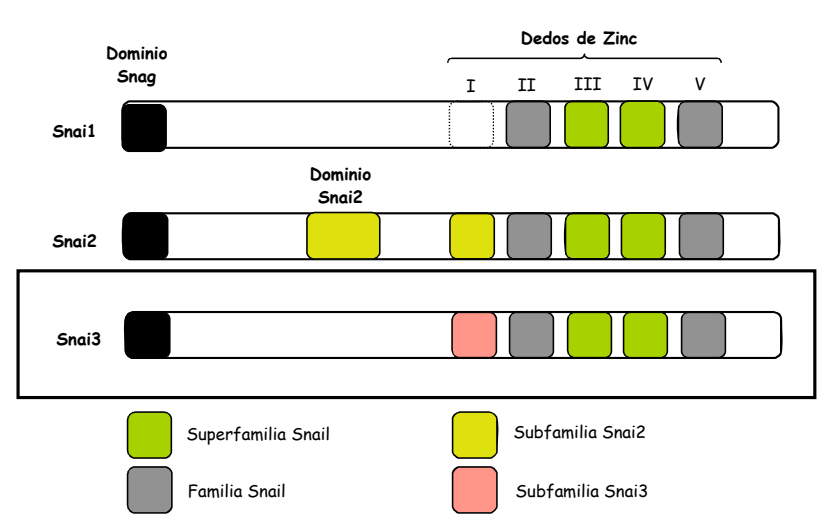

Figura 56: Dominios específicos en vertebrados que definen la familia Snail. Snai3, un miembro de la familia Snail muestra igual que los miembros Snail y Snai2 el dominio SNAG (negro) y el dominio en dedos de zinc. En base al número de dedos de zinc observados, Snai3 parece más a Snai2 que a Snail. Figura modificada de (Manzanares et al., 2001).

En los últimos años han aparecido varias publicaciones en relación con la función de los miembros Snai1 y Snai2 en el proceso de la EMT (Batlle et al., 2000; 
Bolos et al., 2003; Cano et al., 2000; Peinado et al., 2007; Peinado et al., 2003), así como también en varios procesos más (Barrallo-Gimeno and Nieto, 2005; Cobaleda et al., 2007; Manzanares et al., 2001; Nieto, 2002; Vega et al., 2004; Wu et al., 2005). Sin embargo, en el caso de Snai3, si se realiza una búsqueda en la pagina web de PUBMED aparecen únicamente 8 artículos, la mayoría de los cuales hablan de su homología con los otros miembros de la familia Snail y de su expresión en los tejidos en el embrión y en el ratón adulto, pero no de su función celular.

La importante función de los otros dos miembros de la familia Snail, Snai1 y Snai2, en la EMT, un proceso conservado durante la embriogénesis e importante también durante la progresión de tumores epiteliales, nos llevó a pensar que Snai3 también podría participar en este proceso. Mediante el estudio de la actividad del promotor de E-caderina observamos que Snai3 lleva a cabo una represión muy parecida a la ejercida por Snai1 y Snai2 (Figura 10). Sin embargo, los resultados obtenidos en relación con la capacidad de llevar a cabo el proceso de la EMT mediante la represión o la inducción de marcadores epiteliales o mesenquimales, respectivamente para así inducir un fenotipo mesenquimal, no indican un papel importante de Snai3 en este proceso, ya que no se produce un cambio en el perfil de expresión de estos marcadores (Figura 13), así como tampoco se induce un fenotipo mesenquimal en las células transfectadas. En cualquier caso, es importante tener en cuenta que la represión de $E$ caderina por si sóla, no es suficiente para inducir la EMT y las propiedades invasivas (Nieto, 2008), de la misma manera que su re-expresión en células mesenquimales no induce la reversión hacia un fenotipo epitelial (Navarro et al., 1993).

Así pues no es extraño observar que Snai3 no induce el proceso completo de la EMT. Por otro lado, esto podría coincidir con el hecho que Snai3 ocupa una posición inusual en el árbol filogenético de las proteínas de la familia Snail de vertebrados (Figura 57) y, por tanto, podría actuar de una forma diferente, como hemos comentado ya anteriormente. 


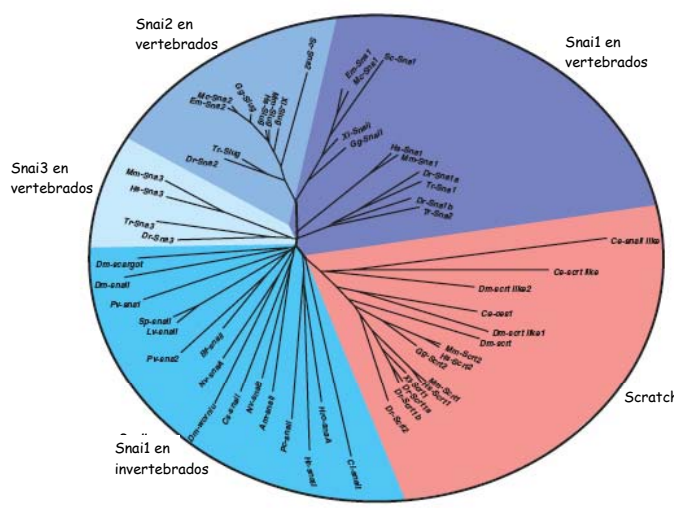

Figura 57. Posición de Snai3 en el árbol filogenético de la superfamilia Snail. Snai3 ocupa una posición inusual dentro de la familia Snail. Am, Acropora millepora (coral); Bf, Branchiostoma floridae (anfioxus); $\mathrm{Ce}$, Caenorhabditis elegans (nemátodo); $\mathrm{Ci}$, Ciona intestinalis (ascidia); Cs, Cupiennius salei (araña); Dm, Drosophila melanogaster (mosca de la fruta); Dr, Danio rerio (pez cebra); Em, Eublepharis macularius (dragón); Gg, Gallus gallus (pollo); Hr, Halocynthia roretzi (ascidia); Hro, Helobdella robusta (sanguijuela); Hs, Homo sapiens (humano); Lv, Lytechinus variegatus (erizo verde de mar); Mc, Mauremys caspica (tortuga); Mm, Mus musculus (ratón); Nv, Nematostella vectensis (anémona); Pc, Podocoryne carnea (medusa); Pv, Patella vulgata (molusco); Sc, Scyliorhinus canicula (tiburón); Sp, Strongylocentrotus purpuratus (erizo de mar); $\mathrm{Tr}$, Takifugu rubripes (pez globo); XI, Xenopus lavéis (sapo

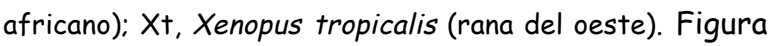
modificada de (Barrallo-Gimeno and Nieto, 2005).

Otra explicación sería que los niveles de expresión de Snai3 no son lo suficientemente altos como para inducir el proceso de EMT, al igual que ocurre en el modelo de ratón CombitTA-Snai1 de nuestro laboratorio, donde no se observan alteraciones epiteliales ni tampoco de carcinomas invasivas (Perez-Mancera et al., 2005b), a pesar de que previamente se he descrito que Snai1 induce la transición epitelio mesenquimal en el ratón (Cano et al., 2000; Olmeda et al., 2008).

En el trabajo de esta tesis hemos observado que hay una regulación entre los miembros Snai2 y Snai3, de manera que Snai2 reprime la expresión de Snai3 en células MEFs (Figura 44). Por ello, sería lógico pensar que sus funciones sean diferentes, puesto que es necesaria la disminución de Snai2 para la expresión de Snai3. Así pues, en el supuesto de que esta regulación entre Snai2 y Snai3 observada en MEFs exista también en otros contextos celulares, como son las MDCK, Snai3 no sería necesario en aquellos contextos celulares donde está actuando Snai2, y puesto que Snai2 ha sido descrito como un inductor del proceso de EMT en MDCK (Bolos et al., 2003), Snai3 no estaría implicado en este proceso.

\section{Papel de Snai3, un miembro de la familia Snail, en la respuesta tras daño en el} DNA

Como hemos explicado anteriormente, p53 es uno de los supresores de tumores más importante y más estudiado en la biología del cáncer, ya que la inactivación del gen que codifica para p53, o el bloqueo de la función de p53 debido a la mutación de los 
componentes en la vía de p53, son eventos muy comunes en los cánceres humanos. La vía de la señalización de p53 se activa en respuesta normalmente tras el daño en el DNA, como ocurre tras irradiación o tras el tratamiento con agentes quimioterapéuticos. Como con consecuencia de la activación de p53, se induce la expresión de proteínas que paran el ciclo celular para permitir la reparación del daño o en el caso de un daño persistente y severo se induce la expresión de proteínas que inician los programas celulares de apoptosis o senescencia (Helton and Chen, 2007). Así pues, p53 tiene una función muy importante en la respuesta celular tras daño en el DNA, y por eso es importante tener p53 estrechamente controlado. No es extraño, por tanto, que existan numerosas publicaciones en relación con esta proteína, y que cada día se descubran nuevas dianas de p53 o nuevas conexiones en su vía de señalización, lo que hace que esta vía sea tan compleja e importante.

Los miembros de la familia Snail, además de participar en la EMT, han sido implicados en la supervivencia celular (Escriva et al., 2008; Inoue et al., 2002; Inukai et al., 1999; Martinez-Alvarez et al., 2004; Peinado et al., 2003; Perez-Losada et al., 2003; Perez-Losada et al., 2002; Valdes et al., 2004; Wu et al., 2005). Esto encaja con su función en el proceso de la EMT, ya que se cree que la resistencia a la muerte celular conferida por los miembros de la familia Snail, Snai1 y Snai2, proporciona una ventaja selectiva para la migración celular (Kajita et al., 2004; Vega et al., 2004). Esta resistencia a la muerte celular es esencial durante el desarrollo embrionario para que las células migratorias llegan a sus destinos finales, y también va a ser importante en el desarrollo tumoral en el adulto para que las células malignas puedan diseminarse y formar metástasis. Así pues, en situaciones fisiológicas, es lógico esperar una regulación en la expresión de ambos miembros tras diferentes tipos de estrés. Y de hecho, en estudios realizados en nuestro laboratorio hemos observado que el daño en el DNA provocado por el tratamiento con doxorrubicina disminuye la expresión de ambos miembros (Perez-Mancera et al., 2005b); los datos de Snai2 aún no publicados). También se ha observado en nuestro laboratorio que esta disminución en el nivel de expresión de Snai1 y Snai2 tras el daño en el DNA provocado por el tratamiento con doxorrubicina en células MEFs va a estar regulada de forma independiente de p53 en el caso de Snai1 (Perez-Mancera et al., 2005b), y de forma dependiente de p53 en el caso de Snai2 (datos aún no publicados). Esta diferencia en el mecanismo de regulación podría deberse a un intento de asegurarse su expresión durante el desarrollo embrionario (o durante el desarrollo de tumores), puesto que se ha visto que pueden ser 
funcionalmente equivalentes (del Barrio and Nieto, 2002). Pero no solo se ha observado que los miembros de la familia Snail están regulados en respuesta al daño en el DNA, sino que también se ha descrito que el miembro Snai1 puede actuar sobre p53 y así reprimir su expresión (Kajita et al., 2004; Lee et al., 2009).

En el caso de Snai3, utilizando como sistema celular fibroblastos embrionarios de ratón (MEFs), ya que presentan un potente sistema celular para estudiar la respuesta al daño en el DNA, hemos observado que también va estar regulado tras daño en el DNA, al igual que los miembros Snai1 y Snai2. Sin embargo, al contrario que ocurre con los otros miembros Snai1 y Snai2, la regulación de Snai3 tras el daño en el DNA provocado por el tratamiento con doxorrubicina en los MEFs control va a ser positiva, ya que la expresión de Snai3 aumenta tras ese tratamiento (Figura 18A+B). Esta regulación positiva de la expresión de Snai3 tras daño en el DNA fue confirmada en el contexto de las células $\mathrm{Ba} / \mathrm{F} 3$, donde observamos también un aumento en la expresión de Snai3 tras la retirada de la IL-3 (Figura 17). Así pues, la expresión de Snai3 aumenta no solamente tras daño en el DNA, sino también tras la retirada de un factor de crecimiento como es la IL-3. Y también observamos que la regulación de Snai3 tras daño en el DNA va a ser dependiente de p53 (Figura 20A-C, 21 y 22), al igual que ocurre en el caso de Snai2, de tal manera que cuya expresión empieza de aumentar justo en el momento en que p53 también empieza a aumentar. Pero no sólo observamos la existencia de una regulación dependiente de p53, sino que de hecho observamos que Snai3 va a ser una diana directa de p53 (Figura 23), lo cual también se ha descrito en el caso de Snai2 (Wu et al., 2005).

Todos los resultados observados hasta el momento nos llevaron a plantearnos varias preguntas: ¿Por qué los miembros de una misma familia están regulados de manera opuesta tras daño en el DNA?, y, ¿por qué están regulados unos de forma dependiente y otros de forma independiente de p53 tras ese daño? ¿Es porque Snai3 ocupa una posición inusual en el árbol filogenético y quizá por ello podría ejercer una función diferente?

El hecho de que Snai3 aumente su expresión tras el daño en el DNA provocado por el tratamiento con doxorrubicina en los MEFs, así como también tras la retirada de la IL-3 en las células Ba/F3, nos llevó a pensar que Snai3 podría ejercer una función diferente, ya que son dos formas diferentes tras la célula es capaz de inducir la muerte celular por apoptosis. Y tanto de Snai1 como de Snai2 se ha descrito su implicación en 
el proceso de supervivencia celular (Inoue et al., 2002; Inukai et al., 1999; MartinezAlvarez et al., 2004; Perez-Losada et al., 2003; Perez-Losada et al., 2002; Wu et al., 2005). Sin embargo, nuestros estudios no indican una posible función de Snai3 en el proceso de apoptosis (Figuras 27-30). Esto coincide con el hecho de que no observamos una implicación de Snai3 en el disparo de la EMT, puesto que varios estudios han condicionado la conversión a un fenotipo mesenquimal con la supervivencia celular (Kajita et al., 2004), como hemos comentado anteriormente para los miembros Snail y Snai2 de la familia Snail. De hecho, más que favorecer el proceso de apoptosis podría pensarse incluso que Snai3 se comporta como una proteína anti-apoptótica, puesto que parece observarse un descenso mínimo en la activación de la forma activa de la Caspasa 3 en los MEFs infectados con Snai3 cuando se compara con los MEFs Mock (Figura 27B). Este resultado encajaría con el hecho de que Snai3, como miembro de la familia Snail, participa en procesos similares a los otros miembros, Snai1 y Snai2, y así habría una relación entre ellos. Sin embargo, debido a que su regulación tras daño en el DNA es opuesta a la de los otros miembros de la familia Snail, sería más lógico pensar que actúe de forma contraria, induciendo, por tanto, la muerte celular por apoptosis, o quizá simplemente que no participe en esa respuesta celular tras daño en el DNA.

Otra pregunta que nos surgió, fue: ¿O es que Snai3 no llega a ser traducido a proteína y por eso no observamos la existencia de la proteína Snai3 en situaciones fisiológicas mediante Western Blot? La posibilidad de que Snai3 fuera degradado rápidamente la descartamos en parte porque no observamos un aumento en la expresión proteica de Snai3 tras el uso del inhibidor del proteasoma MG132 (Figura 19). Sin embargo, también podría ser que el anticuerpo no sea el adecuado para detectar los niveles de expresión endógenos, en cualquier caso podrían existir otros mecanismos de regulación que podrían impedir la traducción de mRNA de Snai3. Además, hay que tener en cuenta que los niveles de expresión a nivel de RNA también son bajos, ya que la banda que observamos mediante Northern Blot es muy debil (Figura 18A).

Teniendo en cuenta la importante función de p53 en la respuesta tras daño en el DNA, y la importancia de tener estrechamente controladas todas las proteínas de esta vía de señalización, sería lógico que Snai3 también tuviera un papel importante en esta vía, puesto que como ya hemos comentado nuestros resultados nos indican que Snai3 está regulado positivamente y de forma directa por p53 tras daño en el DNA. Sin embargo, no parece inducir el proceso de la muerte celular, ni in vitro ni in vivo. 
Otro proceso inducido tras daño en el DNA es la parada del ciclo celular. Los resultados obtenidos en los estudios sobre la función de Snai3 en el control del ciclo celular y la proliferación nos muestran una posible implicación de Snai3 en este proceso, puesto que las células infectadas con Snai3 proliferan menos y muestran un descenso en la fase S (Figura 31 y 32). En esta ocasión, Snai3 estaría actuando de forma similar a los otros dos miembros, Snai1 y Snai2, ya que se ha descrito que frenan la proliferación celular (Grosshans and Wieschaus, 2000; Turner et al., 2006; Vega et al., 2004), lo cual sería necesario para que una célula pueda migrar.

Se han descritos numerosos genes diana activados por p53 entre los que se incluyen, aparte de $p 21$ y $m d m-2$, Bax, GADD45, Ciclina $G$, Fas y muchos más, pero de algunos de estos todavía no se ha definido del todo su función en la vía de p53 (elDeiry, 1998). Como hemos mostrado, Snai3 también es una diana directa de p53 y parece estar implicado en el proceso de parada del ciclo celular. Por ello, estudiamos en que punto de la vía de p53 interviene Snai3, y así la asociación con otras proteínas implicadas en ese proceso celular. Una de las cosas que observamos fue un descenso en la expresión de p21 (Figura 33), lo cual nos sorprendió porque p21 es una diana directa de p53 que se induce tras diferentes tipos de estrés en la célula para dar lugar a la parada del ciclo celular (el-Deiry et al., 1993). Así pues, los resultados son muy contradictorios, ya que no encajaría la parada del ciclo celular con un descenso en la expresión de p21. Sin embargo, el hecho de que p53 induce la parada del ciclo celular a través de la inducción de proteínas que están implicadas en esa misma vía, apoyaría la posible función de Snai3 en el control del ciclo celular, puesto que la expresión de Snai3 también aumenta tras daño en el DNA. Por tanto, la disminución en la expresión de p21 observada en los MEFs que sobre-expresan Snai3 (cuando se compara con los MEFs Mock) podría ser debida a que los niveles de expresión no son fisiológicos, por lo cual la célula no estaría respondiendo correctamente.

Por otro lado, el hecho de que los miembros Snai2 y Snai3 están regulados de forma opuesta por p53, y que tanto los MEFs control infectados con Snai3 (Figura 33) como los MEFs Snai2 ${ }^{-{ }_{-}}$muestran una menor expresión de p21 (Bermejo-Rodriguez et al., 2006), nos llevó a estudiar la posible regulación entre dichos miembros de la familia Snail. Y así, nuestros resultados nos confirmaron la hipótesis de que Snai2 parece regular Snai3, puesto que Snai2 reprime de forma directa la expresión de Snai3 (Figuras 48-49, 51-53, 55). Puesto que p53 regula de forma directa ambos miembros de la 
familia Snail, y Snai2, por su parte, regula también la expresión de Snai3, diseñamos un posible esquema de la regulación de estos miembros tras daño en el DNA, el cual está representado en la Figura 58.

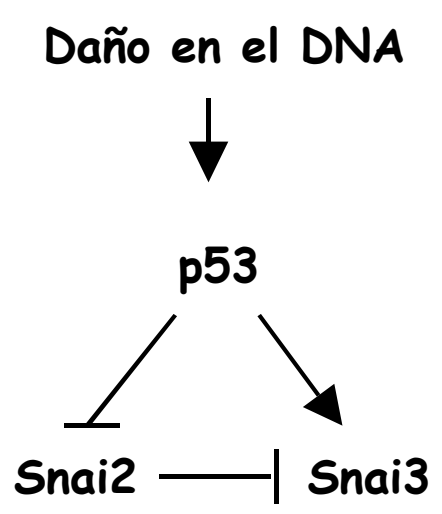

Figura 58: Esquema de la posible regulación de Snai3 en la respuesta tras daño en el DNA. Tras daño en el DNA p53 estaría reprimiendo por un lado la expresión de Snai2 en la célula, y activando por otro lado la expresión de Snai3. Snai2, a su vez, estaría reprimiendo la expresión de Snai3 en la células en condiciones normales, de manera que tras daño en el DNA, al ser reprimida su expresión, la expresión de Snai3 sería de-reprimida.

Por tanto, durante el desarrollo de este trabajo en el que intentamos estudiar la función de Snai3 en la biología celular y tumoral, se nos han presentado muchas más preguntas, y falta todavía mucho para entender cómo Snai3 desarrolla su función en la respuesta tras daño en el DNA. Sin embargo, el mecanismo de la regulación existente entre los miembros Snai2 y Snai3 nos puede dar una idea para estudiar la función de Snai3 en la célula más en detalle.

\section{Papel de Snai3, un miembro de la familia Snail, en la génesis del cáncer}

Snai3 es el tercer miembro de la familia Snail, del cual a el día de hoy se sabe muy poco acerca de su actuación en la biología celular, como hemos comentado anteriormente. En este trabajo hemos estudiado la posible función de Snai3 en los procesos en los que participan los otros miembros Snai1 y Snai2, puesto que Snai1 y Snai2 han demostrado ser funcionalmente equivalentes (Barrallo-Gimeno and Nieto, 2005). Sin embargo, la función concreta de Snai3 en la célula todavía no ha podido ser definida, aunque los resultados obtenidos en este trabajo constituyen un comienzo en el entendimiento de cómo podría actuar Snai3.

Otro proceso importante en el que están implicados Snai1 y Snai2 es la tumorogénesis. Tanto Snai1 como Snai2 han sido implicados en el desarrollo del cáncer, donde se ha observado en muchas ocasiones que el papel de ambos miembros en 
la supervivencia confiere a las células una ventaja selectiva que favorecería además la migración celular y facilitaría la delaminación del tumor primario y su metástasis a otras partes del cuerpo (Barrallo-Gimeno and Nieto, 2005). Así pues, durante los últimos años han aparecido diferentes estudios que defienden la implicación de Snai1 y Snai2 en el mantenimiento del fenotipo mesenquimal (Batlle et al., 2000; Blanco et al., 2002; Cano et al., 2000; Inukai et al., 1999; Khan et al., 1999; Rosivatz et al., 2002; Saito et al., 2004; Sugimachi et al., 2003).

Para entender la contribución de una expresión constitutiva de los miembros de la familia Snail en el desarrollo del cáncer, así como también los mecanismos moleculares a través de los cuales participan en estos procesos cancerígenos, utilizamos un sistema de plásmido-único que contiene los elementos de regulación y expresión del vector binario del sistema original de la tetraciclina, que permite la inducción y un fuerte control de la expresión del gen mediante la administración de la tetraciclina a los ratones (Schultze et al., 1996). El uso de este sistema permitió determinar que ambos miembros favorecen el desarrollo de cáncer (Perez-Mancera et al., 2005a; PerezMancera et al., 2005b).

Mediante el análisis comparativo de hibridaciones genómicas ( $\mathrm{CGH})$, se ha observado la pérdida de la región que contiene al gen SNAI3 en la mayoría de los cánceres humanos, lo que nos llevó a pensar en la importancia que podría tener la pérdida de expresión de Snai3 para el desarrollo tumoral, que indicaría que esta proteína podría actuar en la supresión tumoral.

Así pues, para estudiar la posible implicación de Snai3 en el cáncer utilizamos el mismo sistema, utilizado para los estudios de Snai1 y Snai2 en el desarrollo del cáncer. De esta manera, observamos que la expresión constitutiva de Snai3 en ratones parecía afectar a la vida media de los mismos, puesto que estos ratones morían a edades más tempranas (vida media de aprox 16 meses) que los ratones control (vida media de aprox 28 meses) (Figura 37), lo cual nos podría indicar una implicación de Snai3 en la patología del ratón. El análisis de los ratones CombitTA-Snai3 para determinar la causa de su muerte temprana puso de manifiesto que estos ratones desarrollaban cáncer, en la mayoría de los casos tumores mesenquimales, principalmente tumores mieloides, aunque también observamos el desarrollo de tumores epiteliales, aunque en un porcentaje mucho menor (Figura 38). Así pues, los ratones CombitTA-Snai3, al igual que los ratones CombitTA-Snail y CombitTA-Snai2, desarrollaban principalmente 
tumores hematopoyéticos (Perez-Mancera et al., 2005a; Perez-Mancera et al., 2005b). Sin embargo, los tumores mesenquimales encontrados en los ratones CombitTA-Snail y CombitTA-Snai2 eran en gran parte leucemias agudas (Perez-Mancera et al., 2005a; Perez-Mancera et al., 2005b).

Como ya hemos comentado anteriormente, p53 es una molécula clave e importante en la protección de la célula tras varios tipos de estrés celular. Por tanto, no es extraño observar que la pérdida de expresión de p53 constituye un paso importante en el proceso de transformación celular. Esto se ve confirmado por el hecho de que aproximadamente el 50\% de los tumores humanos tienen mutaciones que inactivan el gen TP53 (Hollstein et al., 1994), y el 50\% restante de los tumores retienen el gen pero la mayoría tienen la función de p53 bloqueada debido a la mutación de los componentes de la vía de p53 (Prives and Hall, 1999; Sharpless and DePinho, 1999; Woods and Vousden, 2001).

Además muchas de las mutaciones descritas en p53 se han relacionado con el síndrome de Li-Fraumeni.

Los individuos afectados por este síndrome desarrollan tumores específicos a edades más tempranas de lo normal (Malkin et al., 1990; Srivastava et al., 1990). Si se comparan los tipos de tumores que se desarrollan espontáneamente cuando p53 está mutado somáticamente, con los tumores desarrollados de los individuos afectado por el síndrome Li-Fraumeni, se puede observar que más de la mitad de los tumores se encuentran en ambos casos (Malkin 1990).

Así pues, en consecuencia, muchos grupos de investigación se centraron en estudiar la función de p53 en modelos animales, donde también pusieron de manifiesto la importante función de p53 en la prevención del desarrollo tumoral, puesto que estos ratones $\mathrm{p} 53^{-/}$, aunque viables, son susceptibles a desarrollar tumores espontáneos en edades tempranos (Donehower et al., 1992; Gondo et al., 1994; Jacks et al., 1994; Purdie et al., 1994; Tsukada et al., 1993), mientras que los ratones heterocigotos para p53 tienen un retraso comparativo en la aparición de tumores (Donehower et al., 1992; Donehower et al., 1995; Harvey et al., 1993). Además, observaron que mientras los ratones $\mathrm{p} 53^{-/-}$desarrollan con gran incidencia linfomas, normalmente del timo (Donehower et al., 1992; Donehower et al., 1995; Harvey et al., 1993; Jacks et al., 1994;

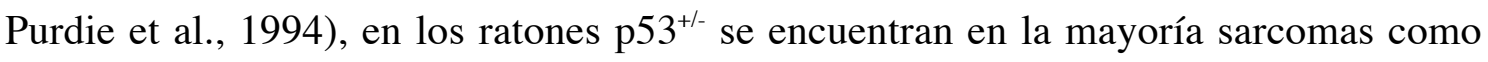
osteosarcomas, sarcomas de tejidos blandos seguidos de linfomas (Donehower et al., 1995; Harvey et al., 1993; Jacks et al., 1994). 
MATERIALES Y MÉTODOS 


\section{Generación de las construcciones}

\subsection{Obtención de la secuencia codificante de Snai3}

El cDNA de ratón de Snai3 (PubMed: NM_013914) se amplificó mediante PCR (Polymerase Chain Reaction) utilizando como molde RNA procedente de MEFs control (ver apartado 5.2.) que previamente tratamos con DNasa I.

\subsubsection{Tratamiento del RNA con DNasaI}

Para eliminar la posible contaminación de DNA genómico producida durante la obtención del RNA (descrito en el punto 6.1.1.), el RNA procedente de MEFs control se

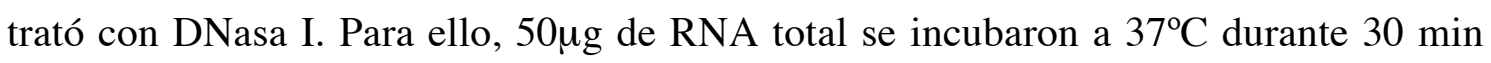
con $0,25 \mu l$ (10U) del inhibidor de ribonucleasas RNasin (Promega), 10 $\mu 1$ de tampón DNasa I (10mM Tris-HCl pH 8,0; $50 \mathrm{mM} \mathrm{KCl;} 1,5 \mathrm{mM} \mathrm{MgCl}_{2}$ ) y $5 \mu$ l (10 U) de DNasa I (HT Biotechnology LTD) en un volumen final de 50 $\mu 1$. Posteriormente, el RNA se purificó mediante extracción con 1 volumen de fenol/cloroformo (3/1), y posterior precipitación a $-70^{\circ} \mathrm{C}$ durante 20 min con 4 volúmenes de etanol/acetato sódico $3 \mathrm{M}$ pH:5,2 (24:1). Finalmente, las muestras se centrifugaron a $4^{\circ} \mathrm{C}$ durante 10 min a 14000 rpm, y tras limpiar el RNA de sales con 4 volúmenes de etanol al 70\%, se resuspendieron en $20 \mu 1$ de agua bidestilada. La calidad del RNA se comprobó en geles de agarosa libres de RNasa, y el cálculo de su concentración se determinó mediante espectrofotometría a $260 \mathrm{~nm}$ (Ultrospec 1000E, Pharmacia Biotech).

\subsubsection{Obtención de cDNA a partir de RNA tratado con DNasaI}

Para ello, $5 \mu \mathrm{g}$ de RNA se desnaturalizaron a $65^{\circ} \mathrm{C}$ durante 5 min en presencia de $1 \mu \mathrm{l}$ (40U) de RNasin (Promega) y agua bidestilada hasta un volumen final de $13 \mu 1$. Posteriormente, se añadieron $1 \mu 1$ de oligo(dT) ${ }_{15}$ (Promega), $1 \mu l$ de RNasin (Promega), $4 \mu \mathrm{l}$ de tampón de transcripción reversa $(10 \mathrm{mM}$ Tris- $\mathrm{HCl} \mathrm{pH} 8,3 ; 20 \mathrm{mM} \mathrm{KCl} ; 2 \mathrm{mM}$ $\mathrm{MgCl}_{2} ; 1 \mathrm{mM}$ DTT; $100 \mu \mathrm{M}$ de la mezcla de nucleótidos dATP, dCTP, dGTP, dTTP (Amersham Pharmacia)) y $1 \mu \mathrm{l}(21 \mathrm{U})$ de transcriptasa reversa (Super-RT; HT Biotechnology LTD), y la reacción se incubó a $42^{\circ} \mathrm{C}$ durante 1 h. Por último, las muestras se diluyeron añadiendo $80 \mu 1$ de agua bidestilada. 


\subsubsection{PCR a partir del CDNA}

La amplificación se realizó con $10 \mu 1$ de cDNA, 5 $\mu 1$ de tampón PCR 5X (Promega), 1,5mM $\mathrm{MgCl}_{2} ; 200 \mu \mathrm{M}$ de la mezcla de nucleótidos dATP, dCTP, dGTP, dTTP (Amersham Pharmacia)); 3 pmoles de cada oligonucleótido y 0,5ul de Pfu Turbo® DNA Polimerasa (1,25U; Stratagene), en un volumen de 50 $\mu 1$.

Para la amplificación de Snai3 se utilizaron los siguientes oligonucleótidos, a los que se añadieron sitios de restricción en los extremos para favorecer su posterior clonación:

\section{NcoI NotI}

\section{Foward: 5'-GCCCATGGCGGCCGCGATGCCGCGCTCCTTCCTGGTG -3'}

\section{SalI EcoRI}

\section{Reverse: 5'-GCGTCGACGAATTCCTAGGGGCCAGGACAGCAGCC-3'}

El programa utilizado fue un ciclo inicial de $\left[95^{\circ} \mathrm{C}, 5 \mathrm{~min}\right]$ seguido de 25 ciclos de $\left[95^{\circ} \mathrm{C}, 1 \mathrm{~min} / 60^{\circ} \mathrm{C}, 1 \mathrm{~min} / 72^{\circ} \mathrm{C}, 1 \mathrm{~min}\right]$ y un ciclo de $\left[72^{\circ} \mathrm{C}, 10 \mathrm{~min}\right]$.

El producto amplificado por PCR de aprox $865 \mathrm{pb}$, que se corresponden con el cDNA completo de Snai3 que incorpora en sus extremos sitios de restricción, se visualizó y se purificó a partir de un gel de agarosa al 1\%. Para ello, utilizamos un kit para la purificación rápida de fragmentos extraídos de geles de agarosa $\left(\right.$ CONCERT $^{\mathrm{TM}}$; Life technologies; GibcoBRL) siguiendo las especificaciones del fabricante. Una vez purificado, se clonó en pBluescript $\mathrm{KS}^{+}$, para posteriormente poder secuenciarlo y comprobar que no contiene mutaciones, y una vez comprobada su secuencia se extrajo para su posterior subclonación en los vectores de interes. La metodología empleada se describe a continuación.

\subsubsection{Ligación del cDNA de Snai3 en el vector pBluescript KS+}

Tras la amplificación y purificación por PCR del cDNA de Snai3, éste se clonó en el vector pBluescript $\mathrm{KS}^{+}$linearizado con EcoRV. Para la linearización del vector se digirió $2 \mu \mathrm{g}$ del mismo con EcoRV durante $5 \mathrm{~h}$ a $37^{\circ} \mathrm{C}$, en una reacción que contenía un buffer específico (New England Biolabs) (10mM Tris-HCl; 10mM $\mathrm{MgCl}_{2} ; 1 \mathrm{mM}$ DTT; $50 \mathrm{mM} \mathrm{NaCl} ; \mathrm{pH} 7,9), 0,1 \mu \mathrm{g} / \mu \mathrm{l} \mathrm{BSA}$, y $6 \mu 1$ de enzima EcoRV (120U) (New England Biolabs) en un volumen final de $100 \mu 1$. A continuación, la reacción de digestión se inactivó durante $1 \mathrm{~h}$ a $70^{\circ} \mathrm{C}$. El cDNA de Snai3 se ligó a pBluescript $\mathrm{KS}^{+}$en la siguiente reacción de ligación: $1 \mu 1$ (20ng) de pBluescript $\mathrm{KS}^{+}$linearizado con EcoRV; $7 \mu 1$ (40ng) 
de cDNA de Snai3; $1 \mu 1$ de tampón T4-DNA ligasa (New England Biolabs) y $1 \mu 1$ (1U) de la enzima T4-DNA ligasa (New England Biolabs), incubándose durante $2 \mathrm{~h}$ a temperatura ambiente y, posteriormente, a $16^{\circ} \mathrm{C}$ durante $16 \mathrm{~h}$.

\subsubsection{Preparación de DH5 $\alpha$ competente y transformación plasmídica}

El producto de las ligaciones se transformó en la cepa de Escherichia coli DH5 $\alpha$, hecha competente mediante el método del $\mathrm{CaCl}_{2}$ siguiendo el siguiente protocolo: se creció una colonia de DH5 $\alpha$ en $5 \mathrm{ml}$ de $2 \mathrm{XTY}$ a $37^{\circ} \mathrm{C}$ durante $16 \mathrm{~h}$. Posteriormente, el cultivo se diluyó 1/100 en $100 \mathrm{ml}$ de 2 XTY y se recreció a $37^{\circ} \mathrm{C}$ durante 2 h hasta alcanzar una OD $(600 \mathrm{~nm})$ de 0,6. Los cultivos se transfirieron a dos tubos FALCON y se incubaron en hielo durante $15 \mathrm{~min}$, tras lo cual, se centrifugaron a $4^{\circ} \mathrm{C}$ durante $5 \mathrm{~min}$ a $1.500 \mathrm{rpm}$. El tapón celular se resuspendió en $50 \mathrm{ml}$ de $\mathrm{CaCl}_{2} 0,1 \mathrm{M}$ y se incubó en hielo durante 15 min. Tras centrifugar en las mismas condiciones, se volvió a resuspender en $5 \mathrm{ml}$ de $\mathrm{CaCl}_{2}$ 0,1M, y tras incubar en hielo durante $60 \mathrm{~min}$, las células eran competentes y estaban listas para ser usadas en la transformación.

Para la transformación plasmídica se incubaron $200 \mu$ l de DH5 $\alpha$ competente con $5 \mu 1$ de la reacción de ligación durante 30min en hielo. Posteriormente, la mezcla se sometió a un choque de calor a $42^{\circ} \mathrm{C}$ durante $2 \mathrm{~min}$, y recuperamos las células añadiendo $400 \mu \mathrm{l}$ de $2 \mathrm{XTY}$ e incubando a $37^{\circ} \mathrm{C}$ durante $30 \mathrm{~min}$. Por último, las bacterias transformadas se sembraron en placas LB (1\% agar; $1 \%$ triptona (OXOID); 0,5\% extracto de levadura (DIFCO), $1 \% \mathrm{NaCl}$ (Panreac) ajustado a $\mathrm{pH}:$ 7,4) suplementadas con ampicilina $(100 \mu \mathrm{g} / \mathrm{ml})$, ya que el vector pBluescript tiene resistencia para ampicilina y esto nos va a permitir seleccionar las colonias que han incorporado el vector. Las placas se crecieron a $37^{\circ} \mathrm{C}$ durante $16 \mathrm{~h}$.

\subsubsection{Selección de las colonias con inserto y secuenciación del cDNA}

La selección de las colonias con inserto se realizó mediante el método de búsqueda rápida o turboscreening. Para ello se transfirieron las colonias de las placas a membranas de nylon (Hybond-N, Amersham Pharmacia Biotech) durante 2 min, y se lisaron las células depositando las membranas durante 2 min sobre papel Whatman 3M embebido en solución 2x SSC (0,6M NaCl; 60mM citrato sódico dibásico pH: 7)/5\% SDS precalentada a $65^{\circ} \mathrm{C}$. A continuación se secaron las membranas en un microondas a 900 Watios durante 2 min y, posteriormente, se unió covalentemente el DNA a las 
membranas tratándolas con una fuente de luz UV de $312 \mathrm{~nm}$ durante $20 \mathrm{seg}$ (UV Stratalinker 2400, Stratagene). Una vez fijado el DNA a las membranas, éstas se hibridaron con una sonda frente al cDNA de Snai3. Así, se consiguieron réplicas de las placas en las que las colonias positivas contenían insertos reconocidos por la sonda frente a Snai3. Estas colonias se aislaron y recrecieron a $37^{\circ} \mathrm{C}$ durante $16 \mathrm{~h}$ en $2 \mathrm{ml}$ de 2XTY, obteniéndose el DNA plasmídico utilizando el sistema "CONCERT Rapid Plasmid Miniprep System" (GibcoBRL).

Las construcciones se chequearon mediante la secuenciación del DNA plasmídico. Como partimos de DNA de doble cadena, en primer lugar se desnaturalizó el DNA tratando $10 \mu \mathrm{l}$ de DNA $(10 \mu \mathrm{g})$ con $2,5 \mu \mathrm{l}$ de $\mathrm{NaOH} 2 \mathrm{M}$ a temperatura ambiente durante $10 \mathrm{~min}$. Posteriormente el DNA desnaturalizado se purificó a través de columnas "MicroSpin S-200 HR" (Amersham Pharmacia Biotech). El DNA purificado se secuenció utilizando el "Sequenase version 2.0 DNA Sequencing Kit" (USB). Para la secuenciación se utilizaron los oligos T3 y T7 que anillan en el vector pBluescript a ambos lados del punto de clonación. Además, se generaron diferentes oligos o cebadores a partir de secuencias internas del cDNA de Snai3, que se utilizaron para la secuenciación completa del cDNA, y nos permitieron asegurarnos de que la secuencia amplificada y clonada no contenía ninguna mutación. La reacción se llevó a cabo en tres pasos:

1'.- Unión del cebador al DNA: Se mezclaron $6 \mu 1$ del DNA desnaturalizado con $2 \mu l$ de tampón sequenasa 5x (suministrado en el kit) y 1 pmol de cebador, y la mezcla se incubó a $65^{\circ} \mathrm{C}$ durante $5 \mathrm{~min}$, a $37^{\circ} \mathrm{C}$ durante $10 \mathrm{~min}$ y, por último, a temperatura ambiente durante $5 \mathrm{~min}$.

2ª .- Extensión: A la mezcla anterior se le añadieron $6 \mu 1$ de solución de extensión (3,8 $\mu 1$ agua bidestilada; $1 \mu \mathrm{l}$ DTT $0,1 \mathrm{M} ; 0,3 \mu \mathrm{l}$ "labeling mix 5X" (suministrados en el kit)); 3U Sequenasa Versión 2.0 DNA Polymerasa; 0,65 $\mu 1\left[\alpha-{ }^{35} \mathrm{~S}\right]$-dATP $\left.(12,5 \mathrm{mCi} / \mathrm{ml})\right)$, y se incubó a temperatura ambiente durante $5 \mathrm{~min}$, tras lo cual se pasó a hielo.

$3^{\text {a }}$.- Terminación: Para cada reacción se prepararon 4 reacciones diferentes en una placa de microtitulación. En la placa se añadieron $2 \mu l$ de una solución que contiene $80 \mu \mathrm{M}$ de cada uno de los cuatro deoxinucleótidos (dATP, dCTP, dGTP, dTTP) y $8 \mu \mathrm{M}$ de uno de los dideoxinucleótidos (ddATP, ddCTP, ddGTP o ddTTP) (a cada pocillo uno diferente), y en cada uno de los cuatro pocillos se añadieron $4 \mu 1$ de la mezcla obtenida. 
en el paso de extensión; se mezcló todo ello y la reacción se incubó a $37^{\circ} \mathrm{C}$ durante 5 min. La reacción se paró añadiendo $4 \mu 1$ de la solución de parada (suministrada en el kit). Tendremos, por tanto, cuatro pocillos, uno por cada dideoxinucleótido, para cada reacción de secuencia.

De esta manera obtuvimos cadenas de DNA bicatenario paradas en cada uno de los cuatro nucleótidos, y de diferentes tamaños dependiendo de la posición donde se incorporaron los dideoxinucleótidos a la cadena de DNA. Para poder leer la secuencia, las cadenas se desnaturalizaron a $80^{\circ} \mathrm{C}$ durante $10 \mathrm{~min}$ y, posteriormente, se sometieron a electroforesis vertical en condiciones desnaturalizantes empleando geles de poliacrilamida al 6\% en tampón TBE (90mM TRIS; 90mM ácido bórico; 2mM EDTA $\mathrm{pH}$ : 8) a una potencia de 39 Watios durante $3 \mathrm{~h}$. Posteriormente, los geles se deshidrataron a temperatura ambiente durante 15 min en una solución $10 \%$ ácido acético/10\% metanol, se transfirieron a papel Whatman $3 \mathrm{M}$, se secaron a $80^{\circ} \mathrm{C}$ durante $45 \mathrm{~min}$, y se expusieron a autorradiografía a temperatura ambiente durante $20 \mathrm{~h}$.

\subsection{Generación del vector pQCXIP-Snai3}

\subsubsection{Obtención de la secuencia codificante de Snai3}

La secuencia codificante para la proteína Snai3 de ratón (obtenido como se describe en el punto 1.1.) se extrajo del vector pBluescript $\mathrm{KS}^{+}$mediante la digestión con NotI y EcoRI, que habían sido introducidos en sus extremos 5'y $3^{\prime}$ respectivamente en el momento de su amplificación para favorecer su posterior clonación y que esta digestión genera extremos cohesivos. La reacción de digestión se llevó a cabo durante $2 \mathrm{~h}$ a $37^{\circ} \mathrm{C}$ y contenía $3 \mu \mathrm{g}$ del vector pBluescript-mSnai3, un buffer específico para Eco RI (New England Biolabs) (100mM Tris- $\mathrm{HCl} ; 10 \mathrm{mM} \mathrm{MgCl}_{2} ; 0,025 \%$ Tritón X-100; 50mM $\mathrm{NaCl} ; \mathrm{pH} 7,5), 0,1 \mu \mathrm{g} / \mu \mathrm{l} \mathrm{BSA}$, y $0,5 \mu \mathrm{l}$ de cada enzima, EcoRI y NotI (10U) (New England Biolabs), en un volumen final de $20 \mu 1$. A continuación, la reacción de digestión se inactivó durante $30 \mathrm{~min}$ a $65^{\circ} \mathrm{C}$. Tras la incubación, la reacción se corrió en un gel de agarosa al 1\%. La banda correspondiente al cDNA de Snai3, de aprox 864pb, se purificó, para lo que utilizamos nuevamente el kit para la purificación rápida de fragmentos extraídos de geles de agarosa (CONCERT ${ }^{\mathrm{TM}}$; Life technologies; GibcoBRL) siguiendo las especificaciones del fabricante. 


\subsubsection{Preparación del vector pQCXIP}

Una vez obtenido el cDNA de Snai3 se insertó en el vector de expresión eucariota pQCXIP (BD Biosciences) digerido con NotI y EcoRI, las mismas enzimas con las que cortamos el vector pBluescript-mSnai3.

El vector retroviral pQCXIP es un vector de expresión bicistrónico diseñado para expresar un determinado gen bajo la acción del promotor de citomegalovirus (CMV), junto con un marcador de selección de puromicina (Julius et al., 2000). A continuación de la región promotora del CMV va a existir una región con múltiples sitios de cortes para endonucleasas que facilita el clonaje de los insertos.

Para la linearización del vector se digirió $2 \mu \mathrm{g}$ de vector con NotI y EcoRI durante $5 \mathrm{~h}$ a $37^{\circ} \mathrm{C}$, en una reacción que contenía un buffer específico para EcoRI (New England Biolabs), y $6 \mu 1$ de cada enzima NotI y EcoRI (120U) (New England Biolabs), en un volumen final de $100 \mu$ l. A continuación, la reacción de digestión se inactivó durante $30 \min$ a $65^{\circ} \mathrm{C}$.

\subsubsection{Ligación del cDNA de Snai3 en el vector pQCXIP}

El cDNA de Snai3 se ligó al vector en la siguiente reacción de ligación: 1 $\mu 1$ (20ng) de vector linearizado; $7 \mu l$ (40ng) de cDNA de Snai3; 1 $\mu 1$ de tampón T4-DNA ligasa (New England Biolabs) y $1 \mu 1$ (1U) de la enzima T4-DNA ligasa (New England Biolabs), incubándose durante $2 \mathrm{~h}$ a temperatura ambiente y, posteriormente, a $16^{\circ} \mathrm{C}$ durante $16 \mathrm{~h}$.

La transformación plasmídica, la selección de las colonias con inserto, y la secuenciación para verificar que la dirección en que se ha introducido el cDNA en el vector es la correcta, se realizaron de la misma manera descrita en los puntos 1.1.5. y 1.1.6. Para la secuenciación en pQCXIP se utilizaron oligos específicos, que anillan en el vector correspondiente en el vector a ambos lados del punto de clonación del cDNA.

\subsection{Generación del vector CombitTA-Snai3}

\subsubsection{Obtención de la secuencia codificante de Snai3}

La secuencia codificante del gen Snai3 se obtuvo como se ha descrito en el punto 1.2.1.. 


\subsubsection{Preparación del vector CombitTA}

El vector CombitTASnai3 (TET OFF) de expresión reprimible por tetraciclina, se ha generado insertando la secuencia codificante del gen Snai3, en el vector CombitTA (Schultze et al., 1996). El vector CombitTA contiene un transactivador regulable por tetraciclina (tTA) formado por la fusión de dos proteínas; el represor del operón Tn10 (tetR) y el dominio de activación de la proteína VP16 del virus herpex simplex.

La secuencia de cDNA de ratón de Snai3 se introdujo en el sitio ScaI del vector CombitTA. De esta manera se generaró el vector CombitTASnai3, que contiene todos los elementos del operón Tn10 necesarios para controlar la expresión del gen Snai3. Estos elementos están situados en unidades transcripcionales independientes, con orientaciones opuestas y flanqueadas por secuencias de poliadenilación para garantizar la independencia de la transcripción. Este vector confiere resistencia a kanamicina, lo que permite su selección en bacterias (Figura 59).

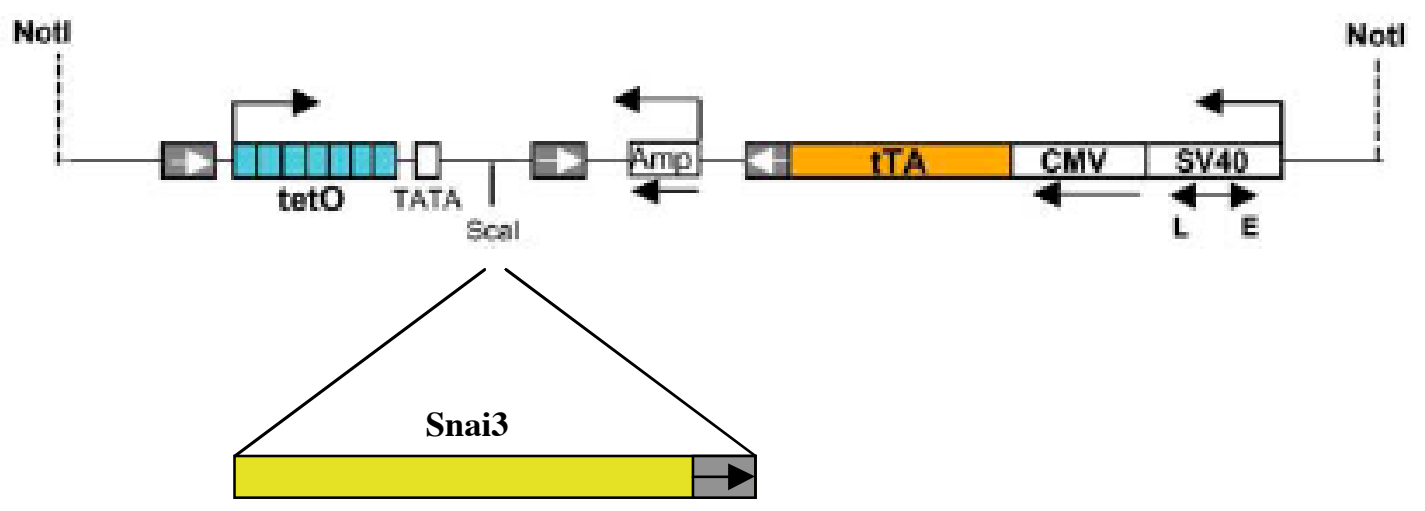

Figura 59: Esquema del vector CombiTA-Snai3 usado en los estudios.

Para la linearización del vector se digirió $2 \mu \mathrm{g}$ del mismo con ScaI durante $5 \mathrm{~h}$ a $37^{\circ} \mathrm{C}$, en una reacción que contenía un buffer específico (New England Biolabs), $0,1 \mu \mathrm{g} / \mu 1 \mathrm{BSA}$, y $6 \mu 1$ de enzima ScaI (120 U) (New England Biolabs) en un volumen final de $100 \mu 1$. A continuación, la reacción de digestión se inactivó durante 30 min a $65^{\circ} \mathrm{C}$.

\subsubsection{Ligación del cDNA de Snai3 en el vector CombitTA}

El cDNA de Snai3 se ligó al vector en la siguiente reacción de ligación: $1 \mu$ l (20ng) de vector linearizado; $7 \mu 1$ (40ng) de cDNA de Snai3; $1 \mu 1$ de tampón T4-DNA ligasa (New 
England Biolabs) y $1 \mu 1$ (1U) de la enzima T4-DNA ligasa (New England Biolabs), incubándose durante $2 \mathrm{~h}$ a temperatura ambiente y, posteriormente, a $16^{\circ} \mathrm{C}$ durante $16 \mathrm{~h}$.

La transformación plasmídica, la selección de las colonias con inserto, y la secuenciación para verificar que la dirección en que se ha introducido el cDNA en el vector es la correcta, se realizaron de la misma manera descrita en los puntos 1.1.5. y 1.1.6.

\subsection{Generación del vector pEGFP-C1-Snai3}

\subsubsection{Obtención de la secuencia codificante de Snai3}

El fragmento de mSnai3, obtenido como se describe en el punto 1.2.1..

\subsubsection{Preparación del vector pEGFP-C1}

El vector pEGFP-C1 (CLONTECH Laboratories) es un vector de fusión de proteína cterminal que codifica para la proteína GFP bajo la acción del promotor de citomegalovirus (CMV), junto con un marcador de selección de neomicina. A continuación de la región promotora del CMV va a existir la secuencia del gen EGFP y después una región con múltiples sitios de cortes para endonucleasas que facilita el clonaje de los insertos. De esta manera el gen clonado se expresa como fusión con el Ct de EGFP.

La secuencia codificante para la proteína Snai3 de ratón se extrajo del vector pBluescript $\mathrm{KS}^{+}$mediante la digestión con NcoI y EcoRI. La digestión con NcoI y EcoRI genera extremos cohesivos, y por ello, para convertirlos en extremos romos que permitan la clonación, el vector linearizado se incubó durante 30 min a temperatura ambiente con $1 \mu 1$ (2U) del fragmento Klenow de la DNA polimerasa I (Roche) en presencia de dNTPs $(1 \mathrm{mM})$. Tras la incubación, se inactivó nuevamente la reacción durante $30 \min$ a $65^{\circ} \mathrm{C}$.

Para la linearización del vector se digirieron $2 \mu \mathrm{g}$ de vector con EcoRI durante 5 h a $37^{\circ} \mathrm{C}$, en una reacción que contenia un buffer específico para EcoRI (New England Biolabs), y $6 \mu 1$ de enzima EcoRI (120U) (New England Biolabs), en un volumen final de $100 \mu$ l. A continuación, la reacción de digestión se inactivó durante 30 min a $65^{\circ} \mathrm{C}$. La digestión con EcoRI genera extremos cohesivos, y por ello, se tenía que generar extremos romos de la misma manera descrita como para el fragmento. 


\subsubsection{Ligación del cDNA en el vector pEGFP-C1}

El cDNA de Snai3 se ligó al vector en la siguiente reacción de ligación: $1 \mu 1$ (20ng) de vector linearizado; $7 \mu 1$ (40ng) de cDNA de Snai3; $1 \mu 1$ de tampón T4-DNA ligasa (New England Biolabs) y $1 \mu 1$ (1 U) de la enzima T4-DNA ligasa (New England Biolabs), incubándose durante $2 \mathrm{~h}$ a temperatura ambiente y, posteriormente, a $16^{\circ} \mathrm{C}$ durante $16 \mathrm{~h}$.

La transformación plasmídica (este vector tiene resistencia para kanamicina en E.coli), la selección de las colonias con inserto, y la secuenciación para verificar que la dirección en que se ha introducido el cDNA en el vector es la correcta, se realizaron de la misma manera descrita en los puntos 1.1.5. y 1.1.6.

\subsection{Generación del vector pGL3-mSnai3 (2785bp)}

\subsubsection{Obtención de la secuencia del promotor de Snai3}

El fragmento del promotor de Snai3 de ratón se obtuvo en dos pasos utilizando como molde DNA procedente de MEFs control.

$1^{\text {a }}$-- Amplificación de una parte del promotor de Snai3 mediante RT-PCR utilizando los siguientes oligos, a los que se añadieron sitios de restricción en los extremos para favorecer su posterior clonación:

\section{SacII}

mSnai3promt-F: 5`- GCCGCGGGGTCGGTGCGT G - 3`

\section{XhoI}

mSnai3promt-R: $3 `$ - GCTCGAGGGTCCCCTCCCGAGAGCAGG - 3`

La amplificación se realizó con $1 \mu 1$ de DNA, $5 \mu 1$ de tampón Pfu 10x (Stratagene), 1,5mM $\mathrm{MgCl}_{2} ; 200 \mu \mathrm{M}$ de la mezcla de nucleótidos dATP, dCTP, dGTP, dTTP (Amersham Pharmacia)); 3 pmoles de cada oligonucleótido y $1 \mu l$ de Pfu Turbo® DNA Polimerasa (1,25U; Stratagene), en un volumen de 50 $\mu 1$. El programa utilizado fue un ciclo inicial de $\left[95^{\circ} \mathrm{C}, 5 \mathrm{~min}\right]$ seguido de 20 ciclos de $\left[95^{\circ} \mathrm{C}, 1 \mathrm{~min} / 62^{\circ} \mathrm{C}, 1 \mathrm{~min} / 72^{\circ} \mathrm{C}, 1\right.$ min] y un ciclo de $\left[72^{\circ} \mathrm{C}, 10 \mathrm{~min}\right]$.

El producto amplificado por PCR de aprox 283pb, que se corresponde con una parte del promotor de Snai3 $(-283 \rightarrow-1)$ que incorpora en sus extremos sitios de restricción, se visualizó y se purificó a partir de un gel de agarosa al 1,8\%. Para ello, utilizamos un kit para la purificación rápida de fragmentos extraídos de geles de agarosa $\left(\right.$ CONCERT $^{\mathrm{TM}}$; Life technologies; GibcoBRL) siguiendo las especificaciones del fabricante. 
$2^{\mathrm{a}}$.- La otra parte del promotor de Snai3 (-2502 $\left.\rightarrow-283\right)$ se extrajo del vector pBluescript-Snai3 (genómico) mediante la digestión con EcoRI y SacII. La reacción de digestión se llevó a cabo en dos pasos. Primero se digirieron $3 \mu \mathrm{g}$ del vector pBluescriptmSnai3 (genómico) con un buffer específico para EcoRI (New England Biolabs) (100mM Tris-HCl; $10 \mathrm{mM} \mathrm{MgCl}_{2} ; 0,025 \%$ Tritón X-100; $\left.50 \mathrm{mM} \mathrm{NaCl} ; \mathrm{pH} 7,5\right)$ y $0,5 \mu l$ de enzima, EcoRI (10U) (New England Biolabs), en un volumen final de $20 \mu 1$ durante 2 h a $37^{\circ} \mathrm{C}$. A continuación, la reacción de digestión se inactivó durante $30 \mathrm{~min}$ a $65^{\circ} \mathrm{C}$. La digestión con EcoRI genera extremos cohesivos, y por ello, para convertirlos en extremos romos que permitan la clonación, se incubó durante 30 min a temperatura ambiente con 0,5 $\mu$ l (1U) del fragmento Klenow de la DNA polimerasa I (Roche) en presencia de dNTPs $(0,2 \mathrm{mM})$. A continuación, se llevo a cabo la segunda digestión digiriendo la misma reacción nuevamente durante $2 \mathrm{~h}$ a $37^{\circ} \mathrm{C}$, esta vez con $0,5 \mu \mathrm{lde}$ SacII (10U) (New England Biolabs), y posteriormente inactivándola durante 30 min a $65^{\circ} \mathrm{C}$. Tras la incubación, la reacción se corrió en un gel de agarosa al 0,8\%. La banda correspondiente al promotor de Snai3, de aprox 2220pb, se purificó, para lo que utilizamos nuevamente el kit para la purificación rápida de fragmentos extraídos de geles de agarosa (CONCERT ${ }^{\mathrm{TM}}$; Life technologies; GibcoBRL) siguiendo las especificaciones del fabricante.

\subsubsection{Preparación del vector pGL3-basic}

El vector pGL3-basic (Promega) es un vector en lo cual va a ir clonado un fragmento del promotor de Snai3 de ratón delante de un gen reporter de Luciferasa, de manera que cuando se active el promotor va a haber expresión del gen Luciferasa.

Para la linearización del vector se digirieron $2 \mu \mathrm{g}$ de vector con SmaI y XhoI durante $5 \mathrm{~h}$ a $37^{\circ} \mathrm{C}$, en una reacción que contenía un buffer específico (New England Biolabs) (100mM Tris-HCl; $10 \mathrm{mM} \mathrm{MgCl}_{2} ; 0,025 \%$ Tritón X-100; 50mM NaCl; pH 7,5), y $6 \mu 1$ de cada enzima, SmaI y XhoI (120U) (New England Biolabs), en un volumen final de $100 \mu$ l. A continuación, la reacción de digestión se inactivó durante 30 min a $65^{\circ} \mathrm{C}$.

\subsubsection{Ligación del promotor de Snai3 en el vector}

Los dos fragmentos del promotor de Snai3 se ligaron al vector en la siguiente reacción

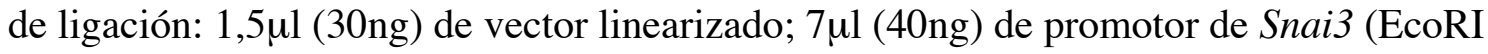
romo/SacII; -2502 $\rightarrow-283 b p) ; 4 \mu l$ (25ng) de promotor de Snai3 (SacII/XhoI; -283 $\rightarrow-1$ ), 
1,5 4 l de tampón T4-DNA ligasa (New England Biolabs) y $1 \mu 1(1 \mathrm{U})$ de la enzima T4DNA ligasa (New England Biolabs), incubándose durante $1 \mathrm{~h}$ a temperatura ambiente y, posteriormente, a $16^{\circ} \mathrm{C}$ durante $16 \mathrm{~h}$.

La transformación plasmídica, la selección de las colonias con inserto, y la secuenciación para verificar que la dirección en que se ha introducido el cDNA en el vector es la correcta, se realizaron de la misma manera descrita en los puntos 1.1.5. y 1.1.6.

\subsection{Generación del vector pBabePuro-mSnai2}

\subsubsection{Obtención de la secuencia codificante de Snai2}

El cDNA de ratón de Snai2 (PubMed: NM_011415) se amplificó mediante PCR (Polymerase Chain Reaction) utilizando como molde RNA procedente de MEFs control (ver apartado 5.2.). Para eliminar la posible contaminación de DNA genómico producida durante la obtención del RNA (descrito en el punto 6.1.1.), el RNA procedente de MEFs control se trató con DNasaI (ver apartado 1.1.1.), y estos fueron utilizados para obtener de cDNA (apartado 1.1.2.).

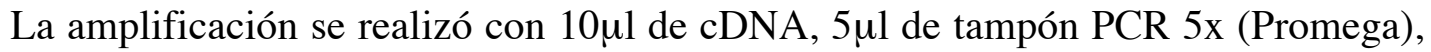
1,5mM $\mathrm{MgCl}_{2} ; 200 \mu \mathrm{M}$ de la mezcla de nucleótidos dATP, dCTP, dGTP, dTTP (Amersham Pharmacia)); 3pmoles de cada oligonucleótido y 0,5 $\mu$ l de Pfu Turbo® DNA Polimerasa (1,25U; Stratagene), en un volumen de 50 $\mu 1$.

Para la amplificación de Snai2 se utilizaron los siguientes oligonucleótidos, a los que se añadieron sitios de restricción en los extremos para favorecer su posterior clonación:

\section{SalI}

Foward: 5'-GCGTCGACATGCCGCGCTCCTTCCTGGT-3'

\section{EcoRI}

\section{Reverse: 5'-GCGAATTCTCAGTGTGCCACACAGCAGC-3'}

El programa utilizado fue un ciclo inicial de $\left[95^{\circ} \mathrm{C}, 5 \mathrm{~min}\right]$ seguido de 25 ciclos de $\left[95^{\circ} \mathrm{C}, 1 \mathrm{~min} / 60^{\circ} \mathrm{C}, 1 \mathrm{~min} / 72^{\circ} \mathrm{C}, 1 \mathrm{~min}\right]$ y un ciclo de $\left[72^{\circ} \mathrm{C}, 10 \mathrm{~min}\right]$.

El producto amplificado por PCR de aprox $800 \mathrm{pb}$, que se corresponden con el cDNA completo de Snai2 que incorpora en sus extremos sitios de restricción, se visualizó y se purificó a partir de un gel de agarosa al 1\%. Para ello, utilizamos un kit 
para la purificación rápida de fragmentos extraídos de geles de agarosa $\left(\right.$ CONCERT $^{\mathrm{TM}}$; Life technologies; GibcoBRL) siguiendo las especificaciones del fabricante. Una vez purificado, se clonó en pBluescript $\mathrm{KS}^{+}$, para posteriormente poder secuenciarlo y comprobar que no contiene mutaciones, y una vez comprobada su secuencia se extrajo para su posterior subclonación en el vector retroviral pBabePuro.

Tras la amplificación y purificación por PCR del cDNA de Snai2, éste se clonó en el vector pBluescript $\mathrm{KS}^{+}$linearizado con EcoRV. Para la linearización del vector se digirió $2 \mu \mathrm{g}$ del mismo con EcoRV durante $5 \mathrm{~h}$ a $37^{\circ} \mathrm{C}$, en una reacción que contenía un buffer específico (New England Biolabs) (10mM Tris-HCl; $10 \mathrm{mM} \mathrm{MgCl}_{2} ; 1 \mathrm{mM} \mathrm{DTT}$; $50 \mathrm{mM} \mathrm{NaCl} ; \mathrm{pH} 7,9), 0,1 \mu \mathrm{g} / \mu \mathrm{l} \mathrm{BSA}$, y $6 \mu 1$ de enzima EcoRV (120U) (New England Biolabs) en un volumen final de $100 \mu 1$. A continuación, la reacción de digestión se inactivó durante $1 \mathrm{~h} \mathrm{a} 70^{\circ} \mathrm{C}$. El cDNA de Snai2 se ligó a pBluescript $\mathrm{KS}^{+}$en la siguiente reacción de ligación: $1 \mu 1$ (20ng) de pBluescript $\mathrm{KS}^{+}$linearizado con EcoRV; $7 \mu 1$ (40ng) de cDNA de Snai2; $1 \mu 1$ de tampón T4-DNA ligasa (New England Biolabs) y $1 \mu 1$ (1U) de la enzima T4-DNA ligasa (New England Biolabs), incubándose durante $2 \mathrm{~h}$ a temperatura ambiente y, posteriormente, a $16^{\circ} \mathrm{C}$ durante $16 \mathrm{~h}$.

El producto de las ligaciones se transformó en la cepa de Escherichia coli DH5 $\alpha$ (ver apartado 1.1.5.) y la selección de las colonias con inserto se realizó mediante el método de búsqueda rápida o turboscreening (ver punto 1.1.6.) con una sonda frente al cDNA de Snai2.

Una vez verificada la secuencia, el cDNA de Snai2 se extrajo del vector pBluescript mediante la digestión con SalI y EcoRI, que habían sido introducidos en sus extremos $5^{\prime}$ y $3^{\prime}$ respectivamente en el momento de su amplificación para favorecer su posterior clonación. La reacción de digestión se llevó a cabo durante $2 \mathrm{~h}$ a $37^{\circ} \mathrm{C}$ y contenía $3 \mu \mathrm{g}$ del vector pBluescript-mSnai2, un buffer específico para EcoRI (New England Biolabs) (100mM Tris- $\mathrm{HCl} ; 10 \mathrm{mM} \mathrm{MgCl}_{2} ; 0,025 \%$ Tritón X-100; 50mM $\mathrm{NaCl} ; \mathrm{pH} 7,5), 0,1 \mu \mathrm{g} / \mu \mathrm{l} \mathrm{BSA}$, y $0,5 \mu 1$ de cada enzima, EcoRI y SalI (10U) (New England Biolabs), en un volumen final de $20 \mu \mathrm{l}$. A continuación, la reacción de digestión se inactivó durante $30 \mathrm{~min}$ a $65^{\circ} \mathrm{C}$. La digestión con SalI y EcoRI genera extremos cohesivos, y por ello, para convertirlos en extremos romos que permitan la clonación, se incubó durante 30 min a temperatura ambiente con 0,5ul (1U) del fragmento Klenow de la DNA polimerasa I (Roche) en presencia de dNTPs $(0,2 \mathrm{mM})$. Tras la incubación, la reacción se corrió en un gel de agarosa al 1\%. La banda correspondiente al cDNA de 
Snai2, de aprox 800 pb, se purificó, para lo que utilizamos nuevamente el kit para la purificación rápida de fragmentos extraídos de geles de agarosa $\left(\right.$ CONCERT $^{\mathrm{TM}}$; Life technologies; GibcoBRL) siguiendo las especificaciones del fabricante.

\subsubsection{Preparación del vector pBabePuro}

El vector de expresión eucariota pBabePuro (Morgenstern and Land, 1990) contiene la secuencia del promotor retroviral gag, seguida por una región con múltiples sitios de cortes para endonucleasas que facilita el clonaje de los insertos; y contiene además un gen de resistencia a puromicina, que se expresa bajo la acción del promotor SV40, que va a ser utilizado como marcador de selección.

Una vez obtenido el cDNA de Snai2 se insertó en el vector pBabePuro digerido con EcoRI.

Para la linearización del vector se digirieron $2 \mu \mathrm{g}$ de vector con EcoRI durante $5 \mathrm{~h}$ a $37^{\circ} \mathrm{C}$, en una reacción que contenia un buffer específico para EcoRI (New England Biolabs) (100mM Tris- $\mathrm{HCl} ; 10 \mathrm{mM} \mathrm{MgCl}_{2} ; 0,025 \%$ Tritón X-100; $50 \mathrm{mM} \mathrm{NaCl} ; \mathrm{pH}$ 7,5), y $6 \mu 1$ de enzima EcoRI (120U) (New England Biolabs), en un volumen final de $100 \mu 1$. A continuación, la reacción de digestión se inactivó durante $30 \mathrm{~min}$ a $65^{\circ} \mathrm{C}$. La digestión con EcoRI genera extremos cohesivos, y por ello, para convertirlos en extremos romos que permitan la clonación, el vector linearizado se incubó durante 30 min a temperatura ambiente con $1 \mu \mathrm{l}(2 \mathrm{U})$ del fragmento Klenow de la DNA polimerasa I (Roche) en presencia de dNTPs (1mM). Tras la incubación, se inactivó nuevamente la reacción durante $30 \min$ a $65^{\circ} \mathrm{C}$.

\subsubsection{Ligación del cDNA en el vector pBabePuro}

El cDNA de Snai2 se ligó al vector en la siguiente reacción de ligación: $1 \mu 1$ (20ng) de vector linearizado; $7 \mu 1$ (40ng) de cDNA de Snai2; $1 \mu 1$ de tampón T4-DNA ligasa (New England Biolabs) y $1 \mu 1$ (1U) de la enzima T4-DNA ligasa (New England Biolabs), incubándose durante $2 \mathrm{~h}$ a temperatura ambiente y, posteriormente, a $16^{\circ} \mathrm{C}$ durante $16 \mathrm{~h}$.

La transformación plasmídica, la selección de las colonias con inserto, y la secuenciación para verificar que la dirección en que se ha introducido el cDNA en el vector es la correcta, se realizaron de la misma manera descrita en los puntos 1.1.5. y 1.1.6.. Para la secuenciación en pBabePuro se utilizaron oligos específicos, que anillan en el vector a ambos lados del punto de clonación del cDNA. 


\section{Generación de ratones modificados genéticamente}

\subsection{Generación de ratones CombitTA-Snai3}

Con el fin de generar ratones que expresaran Snai3 de forma constitutiva, clonamos el cDNA de ratón de Snai3 en una versión modificada del vector CombitTA (Tet Off) (Schultze et al., 1996) (ver apartado 1.3.). Este sistema de expresión, reprimible por tetraciclina, utiliza un único elemento génico que permite tanto la regulación temporal como la regulación cuantitativa de la expresión del gen Snai3. Utilizando este vector, conseguimos sobre-expresar el gen Snai3 un 20\% sobre sus niveles endógenos y por otro lado, controlamos el encendido/apagado del transgén con la adición de doxiciclina al agua de bebida de los ratones.

Para la creación de los nuevos ratones transgénicos CombitTA-Snai3 se linearizó el vector con la enzima de restricción NotI y se purificó el fragmento de DNA que contenía los elementos reguladores de la expresión ligados al cDNA de Snai3. Este transgén fue inyectado en óvulos fertilizados de ratones híbridos CBAxC57BL/6J. Los óvulos pinchados fueron implantados en hembras pseudogestantes donde completaron la gestación. Para identificar los ratones transgénicos, tres semanas después del parto tomamos $2 \mathrm{~mm}$ de la colita de cada uno de los ratones nacidos. De cada colita obtuvimos el DNA genómico mediante incubación de la misma con proteinasa $\mathrm{K}$ y extracción fenol/cloroformo. La detección del transgen en los distintos DNA genómicos se realizó del mediante técnica de Southern Blot tras la digestión del DNA con EcoRI. Utilizamos el cDNA de Snai3 de ratón como sonda para detectar el transgén. Los ratones fundadores fueron cruzados con ratones de la cepa C57BL6J (B6) durante 5 generaciones para estudiar los transgénicos en un fondo genético único (98\% B6).

\subsection{Generación de ratones CombitTA-Snai3;p53--}

Para llevar a cabo nuestros estudios en un fondo genético nulo para el supresor p53 cruzamos nuestros ratones CombitTA-Snai3 con ratones B6 $553^{-/}$. Se cruzaron hembras

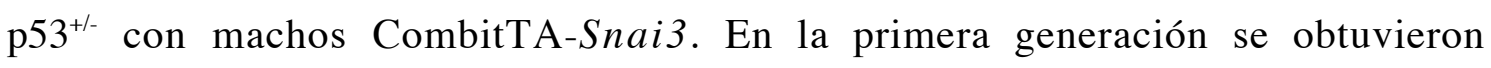
aproximadamente un $25 \%$ de ratones con genotipo CombitTA-Snai3;p53 ${ }^{+/}$. Estos de nuevo se cruzaron con ratones $p 53^{+/-}$para obtener ratones CombitTA de todos los genotipos posibles para $p 53$, entre ellos CombitTA-Snai3;p53 ${ }^{-/-}$, objeto de nuestro estudio. 


\subsection{Generación de ratones Snai $2^{-/-}$}

Con el fin de estudiar el efecto de eliminar la expresión de Snai2 se cruzaron hembras Snai $^{+/-}$con machos Snai2 ${ }^{+/-}$(Jiang et al., 1998). En este cruce se obtuvieron un $25 \%$ de ratones con un genotipo nulo para Snai2, que son los ratones de interés para el estudio.

\subsection{Generación de ratones $\mathrm{p5}^{-{ }^{--}} ;$Snai2 $^{-{ }^{-}}$}

Con el fin de estudiar el efecto de eliminar la expresión de Snai2 en un fondo genético $p 53^{-/-}$se cruzaron hembras $p 53^{+/-}$(Jacks et al., 1994) con machos Snai2 ${ }^{+-}$(Jiang et al., 1998). En la primera generación se obtuvieron un $25 \%$ de ratones heterocigotos para p53 y para Snai2 $\left(\right.$ p53 $^{+/-} ;$Snai2 $\left.2^{+/}\right)$, que se cruzaron entre sí para obtener ratones de todos los genotipos posibles para p53 y para Snai2. En este segundo cruce existen 9 posibles genotipos para los ratones originados, de tal manera que los dobles homocigotos

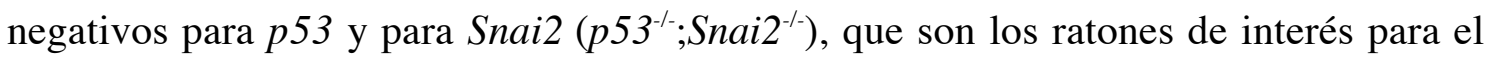
estudio, constituyen $1 / 16$ de la descendencia.

\section{Genotipar los ratónes y los embriones}

\subsection{Mediante Southern blot}

El protocolo utilizado va a ser igual tanto para el análisis de los ratones modificados genéticamente a partir de un trozo de cola, como para el análisis de los embriones a partir del hígado.

\subsubsection{Extracción de DNA a partir de las colas y del hígado de los embriones}

Para la extracción de DNA, las colas y los hígados se trituraron y digirieron en tubos Eppendorf durante $16 \mathrm{~h}$ a $55^{\circ} \mathrm{C}$ en $500 \mu \mathrm{l}$ (1 volumen) de tampón Proteinasa $\mathrm{K}(90 \%$ FORNACE (0,25M sacarosa; $50 \mathrm{mM}$ TRIS pH: 7,4; $\left.25 \mathrm{mM} \mathrm{KCl} ; 5 \mathrm{mM} \mathrm{MgCl}_{2}\right) 1 \%$ SDS; 20mM EDTA pH: 8; 1 $\mu \mathrm{g}$ Proteinasa K (Roche)). Después de la digestión, se

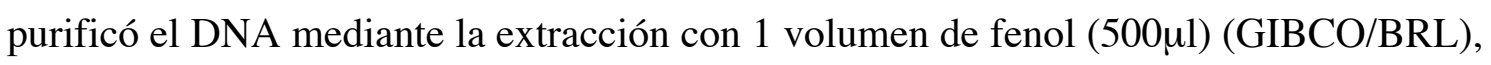

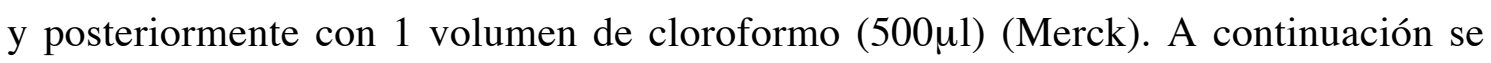
pasó la fase acuosa (superior) a dos volúmenes de etanol absoluto (1ml) (Merck), y se agitaron las muestras hasta conseguir que el DNA se agregara y precipitara formando hilillos. Tras centrifugar las muestras a temperatura ambiente durante 5 min a 13.000 rpm, se limpió el DNA con 1 volumen de etanol al 70\% (500 $\mu 1)$ para eliminar las sales, 
y se resuspendió finalmente en $100 \mu l$ de agua bidestilada. La concentración y la pureza del DNA se determinó mediante espectrofotometría (Ultrospec 1000E, Pharmacia Biotech).

\subsubsection{Digestión de las muestras de DNA}

Se digirieron $10 \mu \mathrm{g}$ de DNA a $37^{\circ} \mathrm{C}$ durante $3 \mathrm{~h}$ en la siguiente reacción de digestión: 33 $\mathrm{mM}$ TRIS acetato; $10 \mathrm{mM}$ acetato de magnesio; $66 \mathrm{mM}$ acetato de potasio; $0,1 \mu \mathrm{g} / \mu \mathrm{l}$ BSA; 1mM DTT; 3mM espermidina y 20U de la enzima de restricción correspondiente en cada caso (New England Biolabs) en un volumen final de 40 $\mu 1$. La endonucleasa de restricción utilizada para genotipar para p53 fue StuI (New England Biolabs), y para genotipar para CombitTA-Snai3 fue EcoRI (New England Biolabs).

\subsubsection{Electroforesis del DNA en geles de agarosa}

Los fragmentos de DNA resultantes de la digestión de las muestras de DNA con la enzima de restricción correspondiente en cada caso, fueron separados por tamaño en geles de agarosa al 1\% en tampón AGB (40 mM TRIS; 0,1\% ácido acético glacial; 0,2 mM Na 2 EDTA; $20 \mathrm{mM}$ acetato de sodio). Para ello, a las muestras de DNA digeridas se le añadieron $8 \mu$ l de tampón de carga 5x (50\% glicerol; 200 mM EDTA pH: 8; 0,1\% azul de bromofenol). Al igual que en el genotipado por PCR, se cargó en paralelo a las muestras a estudiar un marcador de tamaño, que es una mezcla del DNA del fago $\lambda$ digerido con la endonucleasa Hind III (GIBCO/BRL) y del fago $\phi X-174$ digerido con la endonucleasa Hae III (GIBCO/BRL). Después de cargar las muestras en el gel, éstas se sometieron durante $14 \mathrm{~h}$ a una diferencia de potencial de 35 Voltios.

Tras la electroforesis, el gel se introdujo durante 15 min en $500 \mathrm{ml}$ de tampón AGB con bromuro de etidio $(0,5 \mu \mathrm{g} / \mathrm{ml})$, que actúa intercalándose entre las bases nitrogenadas del DNA y nos permite visualizarlo porque emite fluorescencia al exponerse a la luz UV. Para tener una referencia de los tamaños que se buscan tras la hibridación, el gel se fotografió con una cámara Polaroid MP-40 colocando en paralelo una regla. De esta manera teníamos una relación entre la distancia de migración y el peso molecular del marcador de tamaño y, por tanto, podíamos calcular el tamaño de una banda determinada en cualquier punto del gel. 


\subsubsection{Transferencia del DNA a membranas de nylon}

Tras la electroforesis, la visualización del DNA y la toma de fotografías, los fragmentos de DNA separados mediante electroforesis se transfirieron a membranas de nylon (Hybond-N, Amersham Pharmacia Biotech). Para ello, se desnaturalizaron los fragmentos de DNA contenidos en el gel, para obtener cadenas de DNA monocatenarias que nos permitan posteriormente reconocer las secuencias de los genes mediante hibridación con una sonda frente al DNA correspondiente en cada caso. Para desnaturalizar los fragmentos de DNA, el gel se introdujo durante $1 \mathrm{~h}$ en agitación y a temperatura ambiente en solución desnaturalizante $(1,5 \mathrm{M} \mathrm{NaCl} ; 0,5 \mathrm{M} \mathrm{NaOH})$, que va a romper los puentes de hidrógeno entre las cadenas de DNA. Posteriormente, el gel se mantuvo durante $1 \mathrm{~h}$ a temperatura ambiente en agitación en solución neutralizante (1,5M NaCl; $1 \mathrm{M}$ TRIS-HCl pH: 8). A continuación, el DNA se transfirió a la membrana de nylon utilizando como tampón de transferencia 20x SSC $(6 \mathrm{M} \mathrm{NaCl} ; 0,6 \mathrm{M}$ citrato sódico dibásico pH: 7). La transferencia se realizó durante 16 h a temperatura ambiente y, por último, la membrana se trató con una fuente de luz UV de 312nm durante 20 seg (UV Stratalinker 2400, Stratagene) para unir covalentemente el DNA a la membrana.

\subsubsection{Hibridación de las membranas con una sonda marcada con $\left\lceil\alpha{ }^{32} \mathrm{P}\right] \mathrm{dCTP}$}

Las membranas se hibridaron con una sonda de cDNA, específica en cada caso, marcada con $\left[\alpha_{-}{ }^{32} \mathrm{P}\right] \mathrm{dCTP}$. La hibridación del DNA unido a la membrana se realizó en tres etapas:

$1^{\text {a }}$.- Una primera etapa de prehibridación, cuya finalidad es bloquear la hibridación no específica de la sonda a la membrana. Para ello, se incubó la membrana a $65^{\circ} \mathrm{C}$ durante $2 \mathrm{~h}$ en agitación constante en $25 \mathrm{ml}$ de solución de prehibridación (3x SSC $(0,9 \mathrm{M} \mathrm{NaCl} ; 90 \mathrm{mM}$ citrato sódico dibásico $\mathrm{pH}: 7) ; 0,1 \%$ SDS; $1 \mathrm{x}$ solución Denhardt's $(0,2 \mathrm{mg} / \mathrm{ml}$ polivinilpirrolidona (Sigma); $0,2 \mathrm{mg} / \mathrm{ml}$ BSA (Sigma); 0,2mg/ml ficoll 400 (Amersham Pharmacia Biotech)); $5 \%$ sulfato de dextrano y $10 \mathrm{mg} / \mathrm{ml}$ de DNA heterólogo sonicado y desnaturalizado (Sigma)).

$2^{\mathrm{a}}$.- En la etapa de hibridación propiamente dicha, a la mezcla de prehibridación se le añadió la sonda de cDNA marcada radioactivamente mediante el método de random primed o cebado aleatorio. La sonda para p53 se obtuvo mediante la digestión con KpnI y SacII del DNA plasmídico en que estaba clonado; en el caso de Snai3, la sonda se obtuvo mediante la digestión con EcoRI y SalI del DNA plasmídico donde estaba 
clonado. La reacción de marcaje radioactivo se llevó a cabo empleando el sistema "Oligolabelling Kit" (Amershan Pharmacia Biotech). Se marcaron 50ng de DNA resuspendidos en $46 \mu \mathrm{l}$ de agua bidestilada con $3 \mu \mathrm{lde}\left[\alpha{ }^{32} \mathrm{P}\right] \mathrm{dCTP}(3000 \mathrm{Ci} / \mathrm{mmol})$. La reacción se incubó a $37^{\circ} \mathrm{C}$ durante $30 \mathrm{~min}$. Una vez marcada, la sonda se purificó mediante centrifugación a temperatura ambiente durante 5 min a $1.500 \mathrm{rpm}$ a través de columnas de Sephadex G-50, de tal manera que en la columna quedan retenidos los nucleótidos y hexanucleótidos libres, recuperándose la sonda marcada radioactivamente en la solución eluida. La eficiencia de la reacción y la cantidad de sonda marcada radioactivamente se determinó en un contador de radiación- $\beta$ (Quick Count 2000, Bioscan). La hibridación se realizó a $65^{\circ} \mathrm{C}$ durante 16 h con $10^{6} \mathrm{cpm} / \mathrm{ml}$ de la sonda marcada radioactivamente, previamente desnaturalizada a $100^{\circ} \mathrm{C}$ durante 5 min.

$3^{\text {a }}$.- Una vez hibridada, la membrana se sometió a dos lavados de $30 \mathrm{~min}$ en una solución 1X SSC (0,3M NaCl; 30mM citrato sódico dibásico pH: 7)/ 0,1\% SDS precalentada a $65^{\circ} \mathrm{C}$, para eliminar la sonda unida de forma no específica. Tras el lavado, las membranas se expusieron a películas de autorradiografía (Kodak-X-OmatAR) utilizando un intensificador de la señal (Reflection ${ }^{\text {TM }}$ Intesifying Screen; DuPont). La exposición se realizó a $-70{ }^{\circ} \mathrm{C}$ durante 24 h.

\section{2. mediante PCR}

Para genotipar los ratones MEFs Snai2 $2^{+/+}$y MEFs nulo para Snai2 utilizamos el método de RT-PCR.

\subsubsection{RT-PCR para Snai2}

Los ratones mutantes que no expresan el gen Snai2 se obtuvieron mediante el bloqueo del gen Snai2 con un cassette de neomicina que se introdujo en mitad de la secuencia. Por tanto, para genotipar los MEFs se utilizaron dos reacciones diferentes: una que nos permitió detectar el alelo silvestre, y otra que nos permitió detectar el alelo mutado.

Las amplificaciones se realizaron utilizando $1 \mu 1$ de DNA, 2,5 $\mu 1$ de tampón Thermophilic DNA poly 10x (Promega), 1,5mM $\mathrm{MgCl}_{2}, 200 \mu \mathrm{M}$ de la mezcla de nucleótidos dATP, dCTP, dGTP, dTTP (Amersham Pharmacia), 3pmoles de cada oligonucleótido y $0,2 \mu 1$ de la enzima Taq polimerasa (2,5U, Promega), en un volumen final de $25 \mu 1$.

Los oligonucleótidos utilizados en el caso del alelo silvestre fueron: 
- Snai2 KO-1: 5'- AGA ACG GAA GCT GTT CTG -3'

- Snai2 KO-2: 5'-CTA TTT GGT TGG TAA GCA CAT GAG -3'

Los oligonucleótidos utilizados para el alelo mutado fueron:

- Snai2 KO-2: 5'- CTA TTT GGT TGG TAA GCA CAT GAG -3’

- Hox Neo-2: 5'- TCG CCT TCT ATC GCC TTC TTG -3’

El programa utilizado fue de 1 ciclo de $\left[94^{\circ} \mathrm{C}, 4 \mathrm{~min}\right], 40$ ciclos de $\left[94^{\circ} \mathrm{C}, 30 \mathrm{seg} / 60^{\circ} \mathrm{C}\right.$, $\left.1 \mathrm{~min} / 72^{\circ} \mathrm{C}, 1 \mathrm{~min} 30 \mathrm{seg}\right]$ y un ciclo de $\left[72^{\circ} \mathrm{C}, 10 \mathrm{~min}\right]$.

\section{Exposición de ratones a radiación- $\gamma$}

Para estudiar el papel de Snai3 en la inducción de apoptosis en timocitos de ratón, utilizamos ratones wild-type (control), ratones CombitTA-Snai3, ratones $\mathrm{p} 53^{-/-} \mathrm{y}$ ratones CombitTA-Snai3;p53 ${ }^{--}$de 4-6 semanas de edad, y se los sometió a una dosis de 2,5 Gy de radiación- $\gamma$. La irradiación- $\gamma$ se llevó a cabo en un irradiador biológico de rayos- $\gamma$ con fuente de cloruro de Cesio 137 "Gammacell 1000 Elite" (MDS Nordion) con una tasa de dosis de la fuente ${ }^{137} \mathrm{Cs}$ de 2,37 Gy/min para la dosis indicada. 5 horas después de la irradiación se sacrificaron los ratones (tanto los ratones irradiados como los controles sin irradiar) y a continuación, se siguió con los análisis correspondientes.

\section{Cultivos celulares}

\subsection{Tipos celulares utilizados}

Las líneas celulares utilizadas en este trabajo fueron las siguentes: Ba/F3, una línea celular hematopoyetica de ratón dependiente de la IL-3 (Palacios and Steinmetz, 1985), U2OS y SaoS-2, ambas líneas celulares son de osteosarcoma y las MDCK (MadinDarby canine kidney), una línea de células del riñón de perro. Aparte de estas líneas celulares fueron utilizados fibroblastos embrionarios de ratón (MEFs).

\subsection{Obtención de Fibroblastos embrionarios de ratón (MEFs)}

Hembras y machos modificados genéticamente $p 53^{+/-}$fueron cruzadas entre sí para obtener embriones con los 3 genotipos posibles para el gen p53 (+/+, +/- y -/-). De igual manera, los MEFs Snai2 ${ }^{-/}$se obtuvieron del cruce de hembras Snai2 ${ }^{+/}$con machos Snai $^{+/-}$. Los embriones fueron extraídos en el día 13,5 de gestación y se procesaron 
como se describe a continuación para obtener fibroblastos embrionarios primarios (MEFs):

Después de sacrificar a la hembra, se extrajeron los cuernos uterinos con los embriones en su interior y se depositaron en una placa Petri con tampón fosfato salino (PBS: 2,6mM KCl; 1,6mM NaH $\mathrm{PO}_{4} ; 136 \mathrm{mM} \mathrm{NaCl}$ ). Se sacaron los embriones del útero y se pasaron a otra placa Petri con PBS. Se separó el hígado de cada embrión, que será utilizado para obtener DNA y a partir de éste realizar el genotipado de los mismos mediante PCR o Southern blot (ver punto 3), y se desechó el cerebro. El resto de cada embrión se trituró y se resuspendió en $5 \mathrm{ml}$ de tripsina (BioWhittaker), y cada uno de ellos se pasó a una nueva placa donde se dejaron $30 \mathrm{~min}$ a $37^{\circ} \mathrm{C}$, para conseguir la disgregación del tejido que nos permita obtener células individualizadas. A continuación se resupendió cada embrión en los $5 \mathrm{ml}$ de tripsina a los que se añadieron $5 \mathrm{ml}$ de medio. El medio utilizado fue Dulbecco's modified Eagle's (DMEM; Boehringer Ingelheim) suplementado con un 10\% de suero bovino fetal (GIBCO/BRL) inactivado con calor $\left(30 \mathrm{~min}\right.$ a $\left.56^{\circ} \mathrm{C}\right)$ y filtrado por $0,45 \mu \mathrm{m}$ (Millipore), $2 \mathrm{mM} \mathrm{L}$ Glutamina (BioWhittaker), 50 $\mathrm{g} / \mathrm{ml}$ estreptomicina (BioWhittaker) y $50 \mathrm{U} / \mathrm{ml}$ penicilina (BioWhittaker). Una vez disgregados, cada embrión se filtró a través de un filtro de $70 \mu \mathrm{m}$ (BD Falcon; REF\#352350) sobre 10ml de medio, de manera que se obtuvieron suspensiones de células individualizadas. Las células se centrifugaron a $1500 \mathrm{rpm}$ durante $5 \mathrm{~min}$ a temperatura ambiente y, finalmente, el pellet se resuspendió en $1 \mathrm{ml}$ de medio que se repartió entre dos placas Petri de $90 \mathrm{~mm}$ de diámetro $(0,5 \mathrm{ml}$ en cada placa) con $10 \mathrm{ml}$ de medio cada una de ellas. Las células se crecieron a $37^{\circ} \mathrm{C}$ en una atmósfera del $5 \%$ de $\mathrm{CO}_{2}$ hasta confluencia. Durante este tiempo (dos días) se les sustituyó diariamente el medio de cultivo por medio fresco.

Una vez alcanzada la confluencia se procedió a la expansión de las células. Se retiró el medio de las placas (2 placas Petri de $90 \mathrm{~mm}$ de diámetro/embrión), y a continuación se realizaron dos lavados con $5 \mathrm{ml}$ de PBS. Se tripsinizaron $5 \mathrm{~min}$ a $37^{\circ} \mathrm{C}$ en una atmósfera del $5 \%$ de $\mathrm{CO}_{2}$ con $4 \mathrm{ml}$ de tripsina/placa y, finalmente, se resuspendieron bien las células y se repartieron en 4 placas Petri de $135 \mathrm{~mm}$ de diámetro (2ml/placa con $25 \mathrm{ml}$ de medio). Las células se mantuvieron en crecimiento a $37^{\circ} \mathrm{C}$ en una atmósfera del $5 \%$ de $\mathrm{CO}_{2}$ hasta alcanzar nuevamente confluencia (dos días).

Transcurrido ese tiempo las células se utilizaron directamente para los estudios o se congelaron. 
Para la congelación de los MEFs, se procedió de la siguiente manera: se retiró el medio de las placas (4 placas de $135 \mathrm{~mm}$ de diámetro/embrión) y se realizó un lavado con $10 \mathrm{ml}$ de PBS. Se tripsinizó después durante $5 \mathrm{~min}$ a $37^{\circ} \mathrm{C}$ en una atmósfera del $5 \%$ de $\mathrm{CO}_{2}$ con $7 \mathrm{ml}$ de tripsina/placa. Se resuspendieron bien las células con la tripsina y se recogieron en un tubo Falcon con $20 \mathrm{ml}$ de medio. Se centrifugaron 5 min a temperatura ambiente a 1000rpm y se resuspendió el pellet en $4 \mathrm{ml}$ de suero fetal bovino frío. De esos $4 \mathrm{ml}$ se añadieron $0,5 \mathrm{ml}$ en cada vial, en los que previamente se había añadido 0,5ml de suero fetal bovino-20\%DMSO frío. Los viales se agitaron suavemente y se metieron en hielo. Rápidamente se congelaron a $-20^{\circ} \mathrm{C}$ durante un tiempo mínimo de 30 min, a continuación a $-70^{\circ} \mathrm{C}$ durante un tiempo no inferior a $2 \mathrm{~h}$, y finalmente en Nitrógeno líquido $\left(-180^{\circ} \mathrm{C}\right)$.

\subsection{Tratamientos de los MEFs para estudios de expresión génica y/o proteíca}

\subsubsection{Preparación de los MEFs}

Para todos los tratamientos se procedió a la preparación de los MEFs de la misma manera: Las células en cultivo se lavaron con $5 \mathrm{ml}$ de PBS, se tripsinizaron durante 5 min a $37^{\circ} \mathrm{C}$ con $3 \mathrm{ml}$ de tripsina/placa, y se recogieron en tubos Falcon con $20 \mathrm{ml}$ de medio. Posteriormente se procedió al contaje de las células en una cámara Neubauer y se plaquearon $1 \times 10^{6}$ células/placa en placas Petri de $90 \mathrm{~mm}$ de diámetro, que se crecieron a $37^{\circ} \mathrm{C}$ en una atmósfera del $5 \%$ de $\mathrm{CO}_{2}$.

\subsubsection{Tratamiento con doxorrubicina}

A las $24 \mathrm{~h}$ de plaquear se añadió doxorrubicina $(0,2 \mu \mathrm{g} / \mathrm{ml})$ a varias placas de cada tipo celular, y se dejaron otras placas control de cada tipo celular a las que se les cambió el medio por medio fresco. 12 y/ó 24 h después de añadir la doxorrubicina se procedió a recoger las células. Para ello, se lavaron dos veces con $5 \mathrm{ml}$ de tampón PBS, se tripsinizaron $5 \mathrm{~min}$ a $37^{\circ} \mathrm{C}$ con $3 \mathrm{ml}$ de tripsina (BioWhittaker)/placa y se recogieron en tubos Falcon con medio de cultivo (DMEM). Se centrifugaron 5 min a temperatura ambiente a $1000 \mathrm{rpm}$ y se resuspendió el pellet en $1 \mathrm{ml}$ de PBS. Las suspensiones celulares se pasaron a tubos Eppendorf y se centrifugaron 5 min a $4^{\circ} \mathrm{C}$ y a $1000 \mathrm{rpm}$. Se retiró entonces la totalidad del sobrenadante y se congelaron los pellets a $-70^{\circ} \mathrm{C}$ para posteriormente extraer RNA y/o proteínas. 


\subsubsection{Tratamiento con NUTLIN-3}

A las 24 h de plaquear las células, se sustituyó el medio de cultivo de las placas por medio fresco, que se suplementó en unas placas con el enantiómero activo de nutlin-3 (nutlin-3a), con una concentración $4 \mu \mathrm{M}$ en unas placas y $10 \mu \mathrm{M}$ en otras; y en otras placas el medio de cultivo se suplementó con esas mismas concentraciones pero del enantiómero de nutlin-3 inactivo (nutlin-3b). $12 \mathrm{~h}$ después se procedió a recoger las células, de la misma manera descrita en el punto 5.3.2., e igualmente se congelaron los pellets a $-70^{\circ} \mathrm{C}$ para posteriormente extraer RNA y proteínas.

\subsubsection{Tratamiento con MG132}

A las 24 h de plaquear los MEFs, se sustituyó el medio de cultivo de las placas por medio fresco, que se suplementó en unas placas con el inhibidor de proteasoma MG132 (Calbiochem; Ref\# 474790) disuelto en DMSO con una concentración $10 \mu \mathrm{M}$; y en otras placas el medio de cultivo se suplementó con doxorrubicina (ver punto 5.3.2). A la placa control se le añadió el mismo volumen de DMSO como de MG132. 1, 3, 6 y 12 h después se procedió a recoger las células, de la misma manera descrita en el punto 5.3.2., e igualmente se congelaron los pellets a $-70^{\circ} \mathrm{C}$ para posteriormente extraer proteínas.

\subsection{Transducción retroviral}

Los MEFs fueron infectados utilizando un alto título de retrovirus producidos mediante la transfección pasajera de células $\phi N X$ (Serrano et al., 1997). Una vez transfectadas con DNA retroviral, estas células codifican para las proteínas de la cápsida de los retrovirus, que se van a liberar al medio de cultivo.

Los vectores retrovirales utilizados para transfectar las $\phi \mathrm{NX}$, y así obtener retrovirus para infectar los MEFs fueron: pQCXIP (BD Biosciences), pQCXIP-Snai3 (ver punto 1.2.), pWZL Hygro-E1A 12s (Serrano et al., 1997), pBabePuro (Morgenstern and Land, 1990) y pBabePuro-Snai2 (ver punto 1.6.). El protocolo utilizado se describe a continuación.

\subsubsection{Preparación de las células $\phi N X$}

Se plaquearon $2 \times 10^{6}$ células $\phi N X /$ placa de $10 \mathrm{~cm}$ de diámetro $24 \mathrm{~h}$ antes de la tranfección en medio Dulbecco’s modified Eagle’s (DMEM; Boehringer Ingelheim) 
suplementado con un $10 \%$ de suero bovino fetal (GIBCO/BRL) inactivado con calor $\left(30 \mathrm{~min}\right.$ a $56^{\circ} \mathrm{C}$ ) y filtrado por $0,45 \mu \mathrm{m}, 2 \mathrm{mM}$ L-Glutamina (BioWhittaker), $50 \mu \mathrm{g} / \mathrm{ml}$ estreptomicina (BioWhittaker) y 50U/ml penicilina (BioWhittaker). Durante ese tiempo las células se crecieron en un incubador a $37^{\circ} \mathrm{C}$ en una atmósfera del $5 \%$ de $\mathrm{CO}_{2}$.

\subsubsection{Preparación del DNA}

Para cada placa de $\phi N X$ a transfectar se precipitaron a $-20^{\circ} \mathrm{C}$, durante un tiempo superior a $2 \mathrm{~h}, 16 \mu \mathrm{g}$ del DNA retroviral correspondiente en un volumen final de $300 \mu \mathrm{l}$ de agua bidestilada, a lo que se añadió $1 \mathrm{ml}$ de etanol-acetato sódico (en una proporción 24:1). Una vez precipitado, el DNA se lavó 3 veces con etanol al 70\%, y se resuspendió finalmente en $30 \mu l$ de agua bidestilada.

\subsubsection{Transfección de las $\phi N X$}

Treinta min antes de la transfección, se sustituyó el medio de cultivo de las $\phi \mathrm{NX}$ por medio suplementado con cloroquina $0,05 \mathrm{mM}$ (SIGMA), y se volvieron a dejar en el incubador. Durante ese tiempo se preparó el DNA para transfectar. Para ello, a los $30 \mu 1$ de agua bidestilada en los que se había resuspendido el DNA, se le añadieron $430 \mu l$ de agua bidestilada y $40 \mu 1$ de $\mathrm{CaCl}_{2} 2 \mathrm{M}$, y se mezcló bien. A continuación, cada DNA se añadió en agitación en un tubo de FACs en el que se habían añadido 500ul de HeBs $\left(\mathrm{NaCl} 274 \mathrm{mM}, \mathrm{KCl} 10 \mathrm{mM}, \mathrm{Na}_{2} \mathrm{HPO}_{4} \cdot 7 \mathrm{H}_{2} \mathrm{O}\right.$ 1,4mM, dextrosa (D-glucosa) $15 \mathrm{mM}$, Hepes $42 \mathrm{mM}$; ajustado a $\mathrm{pH} 7,05$ con $\mathrm{NaOH} 10 \mathrm{~N}$ ) y, posteriormente, se incubaron durante 15 min a temperatura ambiente. Transcurrido ese tiempo, cada uno de ellos se añadió gota a gota en una placa de células $\phi \mathrm{NX}$. Una vez añadido, las placas se volvieron a incubar a $37^{\circ} \mathrm{C}$ en una atmósfera del $5 \%$ de $\mathrm{CO}_{2}$. De 3 a 5 h después de la transfección, se sustituyó el medio de cultivo de las $\phi \mathrm{NX}$ por medio fresco, para así retirar la cloroquina.

\subsubsection{Infección de los MEFs}

El día antes de la infección, se plaquearon dos placas con $1 \times 10^{6}$ células/placa de $10 \mathrm{~cm}$ de diámetro por infección. Para infectar los MEFs, se recogió el medio de cultivo de las $\phi \mathrm{NX}$, que contendrá los retrovirus correspondientes en cada caso liberados en el medio, el cual se suplementó con polybrene $8 \mu \mathrm{g} / \mathrm{ml}$, y se filtró a traves de un filtro de $0,45 \mu \mathrm{m}$ (Millipore). Con el sobrenadante de cada placa de $\phi N X$ filtrado se infectaron dos placas 
de MEFs. Se realizaron 3 infecciones: la primera aprox 18 h después de transfectar las $\phi \mathrm{NX}$, la segunda aprox $6 \mathrm{~h}$ después, y la tercera al día siguiente. Un día después de la última infección las células se expandieron para que no estuvieran confluentes, y se seleccionaron con el antibiótico correspondiente en cada caso. Las células infectadas con los vectores retrovirales pQCXIP y pBabePuro se seleccionaron con puromicina $(2 \mu \mathrm{g} / \mathrm{ml})(\mathrm{CALBIOCHEM})$ durante 3 días. Las células infectadas con pWZL HygroE1A $12 s$ se seleccionaron con higromicina $(100 \mu \mathrm{g} / \mathrm{ml})$ durante 7 días. Durante la selección se cambió el medio de cultivo de las células cada dos días, y las células se expandieron si fue necesario para evitar que alcanzaran confluencia. Tras la selección, se sustituyó el medio de cultivo por medio fresco y se procedió a realizar los estudios correspondientes.

\subsection{Transfección de lineas celulares mediado por fosfato cálcico}

\subsubsection{Preparación de las células}

El día previo a la transfección, las células U2OS y SaoS-2 fueron plaqueadas a una densidad de $1 \cdot 10^{6}$ células por placa de $10 \mathrm{~cm}$ de diámetro en medio DMEM suplementado con $10 \%$ de FCS, 2mM L-Glutamina, $50 \mu \mathrm{g} / \mathrm{ml}$ estreptomicina y 50U/ml penicilina. 2 horas antes de la transfección se lavan las células 2 veces con 1x PBS y después se añade medio fresco

\subsubsection{Transfección de las células}

Las células fueron transfectadas de forma transitoria con un vector que tiene clonado el promotor de Snai3 delante del gen que codifica para la Luciferasa (ver apartado 1.5.). La actividad del promotor se determinó a las 48 horas de la transfección mediante el ensayo de Luciferasa (ver punto 9). De este modo, el DNA plasmídico se introdujo en cultivos celulares monocapa en forma de un precipitado que se adhiere a la superficie celular y entra en la célula vía endocitosis. Este método implica la mezcla directa del DNA con $\mathrm{CaCl}_{2}$ y un buffer con fosfato para formar un precipitado muy fino que se dispersa sobre las células en cultivo. La transfección de las células se realizó utilizando el ProFection Mammalian Transfection System Calcium Phosphate Kit (Promega E1200) y el protocolo se describe a continuación. 
Se mezclaron en un eppendorf $62 \mu 1 \mathrm{de} \mathrm{CaCl}_{2}$ y $438 \mu 1$ de agua libre de nucleasas, junto con 1-5 $\mu$ g del DNA plasmídico a transfectar, que se añadieron, gota a gota, en un falcon de polipropileno (Becton Dickinson) que contenía 500 $\mu 1$ de buffer salino 2xHEPES (2xHBS: $50 \mathrm{mM}$ HEPES pH 7.1, $280 \mathrm{mM} \mathrm{NaCl}, 1.5 \mathrm{mM} \mathrm{Na} \mathrm{HPO}_{4}$, $\mathrm{pH}$ final 7.1). A continuación, los eppendorf se vortexearon para conseguir una suspensión homogénea y se dejaron precipitar durante 30 minutos a temperatura ambiente. El DNA plasmídico se añadió a cada placa como un precipitado en fosfato cálcico. Este precipitado de DNA, que se adhiere a la superficie celular, puede observarse al microscopio, y se mantuvo en las células durante $\sim 16$ horas a $37^{\circ} \mathrm{C}$, tras lo cual se cambió el medio de cultivo añadiendo medio fresco o medio con doxorrubicina (punto 5.3.2.). 48 horas después de la transfección se recogieron las células. Para ello, se lavaron dos veces con 1x PBS y después se añadió $1 \mathrm{ml}$ de PBS 1x a cada placa. Las células se despegadaron de la placa utilizando un rascador y se recogieron en un eppendorf de 1,5ml. Estos eppendorf se centrifugaron 10 minutos a una potencia de $2600 \mathrm{rpm}$ y se guardaron $\mathrm{a}-80^{\circ} \mathrm{C}$ hasta realizar el ensayo de Luciferasa. Como control interno se co-transfectaron las células con el vector pRL-SV40 (Promega), que se añadió en combinación con los otros vectores.

\subsection{Generación de clones estables de MDCK que expresan Snai3 utilizando} FUGENE 6

\subsubsection{Preparación de las células}

El día previo a la transfección, las células MDCK fueron plaqueadas a una densidad de $1 \cdot 10^{6}$ células por placa de $10 \mathrm{~cm}$ de diámetro en medio $\alpha \mathrm{MEM}$ (SIGMA) suplementado con $10 \%$ de FCS, $2 \mathrm{mM}$ L-Glutamina, $50 \mu \mathrm{g} / \mathrm{ml}$ estreptomicina y $50 \mathrm{U} / \mathrm{ml}$ penicilina para estar a una confluencia del 50-80\% en el momento de la transfección.

\subsubsection{Preparación del DNA}

La línea de células epiteliales de riñón de perro (MDCK) se transfectó de forma estable con el plasmido pcDNA3-Snai3 utilizando FuGENE 6. Cuando se quieren hacer líneas celulares estables, es conveniente linealizar el plasmido para dirigir su integración en el genoma de las células. Para la linearización del vector se digirieron $10 \mu \mathrm{g}$ del plasmido con SspI durante $5 \mathrm{~h}$ a $37^{\circ} \mathrm{C}$, en una reacción que contenía un buffer específico para 
SspI (New England Biolabs) y $6 \mu 1$ de enzima SspI (120U) (New England Biolabs), en un volumen final de $300 \mu$ l. A continuación, a la reacción de digestión se le añadieron $200 \mu 1$ de agua bidestilada. Después de la digestión, se purificó el DNA mediante la extracción con 1 volumen de fenol $(500 \mu \mathrm{l})(\mathrm{GIBCO} / \mathrm{BRL})$, después con 1/2 volumen de fenol $(250 \mu 1)(\mathrm{GIBCO} / \mathrm{BRL}) / 1 / 2$ volumen de cloroformo (250 $\mu 1)$ (Merck) y

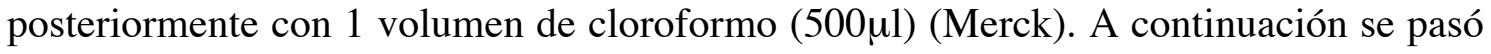
la fase acuosa (superior) a dos volúmenes de etanol absoluto (1ml) (Merck), y se dejaron a $-20^{\circ} \mathrm{C}$ durante 2 horas. Tras centrifugar las muestras a temperatura ambiente durante 5 min a $13.000 \mathrm{rpm}$, se limpió 3 veces el DNA con 1 volumen de etanol al 70\% (500 $\mu 1)$ para eliminar las sales, y se resuspendió finalmente en $10 \mu l$ de agua bidestilada. A partir del último lavado se realizaron todos los pasos en campana para asegurar la esterilidad. El plasmido linealizado fue utilizado para transfectar las células. La transfección fue realizada utilizando FuGENE 6 Transfection Reagent (ROCHE), como se describe a continuación.

\subsubsection{Transfección de las células}

La mezcla del FuGENE 6 con el DNA se realizó en la campana a las 16 horas, aproximadamente, de plaquear las células utilizando medio de cultivos sin suero con un volumen final de 250 $\mu 1$ en una relación 3:2 de FuGENE:DNA (en $\mu 1$ ), aunque las células pueden estar creciendo en medio de cultivos con suero. Los $15 \mu 1$ de FuGENE se añaden directamente en el medio de cultivos sin suero. Después se mezcla suavemente y

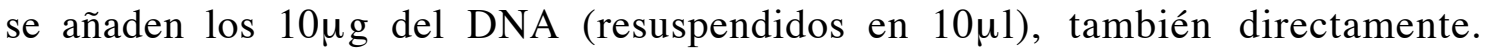
Nuevamente se mezcla suavemente y se deja incubar la mezcla a temperatura ambiente durante 15 min. A continuación se añade gota a gota la mezcla FuGENE/DNA en medio de cultivo sin suero a las células adherentes en la placa, tras lo cual se agita la placa suavemente.

Para seleccionar las células transfectadas con Snai3 se añadió un antibiótico (G418; 0,5mg/ml) al medio de cultivos. Durante la selección se cambió el medio de cultivo de las células cada dos días, y las células se expandieron si fue necesario para evitar que alcanzaran confluencia. Tras la selección, se sustituyó el medio de cultivo por medio fresco. A continuación, se recogieron todas las células seleccionadas, se centrifugaron durante 5 min a temperatura ambiente a máxima potencia y depués se resupendió el pellte en $5 \mathrm{ml}$ de medio de cultivo. De ahí se cogieron $2 \mathrm{ml}$ y se añadieron 
a un FALCON nuevo en un volumen final de $50 \mathrm{ml}$ con medio de cultivo. Después, se contaron las células y se procedió la dilución límite hasta conseguir una concentración de 0,5 células $/ \mathrm{ml}$. Finalmente se plaquearó $1 \mathrm{ml} /$ pocillo de esta suspensión celular en placas de 24 pocillos. Con los clones obtenido mediante el método de la dilución límite se procedió a realizar los estudios correspondientes.

\subsection{Ensayos de proliferación}

Las curvas de proliferación se llevaron a cabo con MEFs control y MEFs $p 53^{-/-}$ infectados con pQCXIP y con pQCXIP-Snai3. Para ello, se plaquearon en placas de doce pocillos $2,5 \times 10^{4}$ células/pocillo y cada dos días se procedió a contar las células de dos pocillos diferentes.

\section{Análisis de la expresión génica}

\section{1. mediante Northern blot}

El análisis de la expresión de los diferentes genes se realizó mediante Northern blot utilizando el RNA obtenido a partir de MEFs (ver punto 5.2.), como se describe a continuación.

\subsubsection{Extracción de RNA total a partir de los MEFs}

Los pellets celulares procedentes de MEFs control, MEFs $p 53^{-/}$, MEFs Snai2 ${ }^{-/}$, MEFs p53 $3^{--} ;$Snai $2^{-/-}$y de los clones de MDCK transfectadas con Snai3 que habíamos guardado previamente a $-70^{\circ} \mathrm{C}$, se resuspendieron en $400 \mu$ l de tampón de lisis $(0,15 \mathrm{M} \mathrm{NaCl}$; $10 \mathrm{mM}$ Tris pH: 7,5;1 $\mathrm{mM} \mathrm{MgCl}_{2} ; 0,5 \%$ Nonidet P40 (BDH)) y se lisaron durante $5 \mathrm{~min}$ en hielo. En esta lisis tan sólo se disgrega la membrana plasmática, y por ello, mediante centrifugación a $4^{\circ} \mathrm{C}$ durante 5 min a $14000 \mathrm{rpm}$, se obtuvo el RNA en el sobrenadante, sin los núcleos celulares. Posteriormente, el RNA se purificó mediante extracción con 1 volumen de fenol/SDS $10 \%$ (4/1), 1 volumen de fenol y posterior precipitación del RNA contenido en la fase acuosa con 3 volúmenes de etanol/acetato sódico $3 \mathrm{M}$ pH 5,2 (24/1). El RNA se precipitó a $-20^{\circ} \mathrm{C}$ durante 5 h, se limpió de sales con 2,5 volúmenes de etanol al $70 \%$ y se resuspendió en $75 \mu 1 /$ tubo de agua bidestilada. La pureza y la integridad del RNA se comprobó en geles de agarosa libres de RNAsa. La medida de la concentración mediante espectrofotometría a 260nm, y el cálculo de la relación entre la 
absorbancia a 260nm y 280nm también nos permitió determinar la cantidad y la calidad del RNA (cuanto más próximo a dos sea el cociente de las dos absorbancias mejor será la calidad del RNA).

\subsubsection{Separación del RNA en un gel de agarosa}

Las muestras de RNA $(20 \mu \mathrm{g})$ se incubaron a $50^{\circ} \mathrm{C}$ durante $1 \mathrm{~h}$ en tampón $0,9 \mathrm{M}$ glioxal (Fluka); $6 \mathrm{mM} \mathrm{Na}_{2} \mathrm{HPO}_{4} ; 4 \mathrm{mM} \mathrm{NaH} \mathrm{PO}_{4} \cdot \mathrm{H}_{2} \mathrm{O}$, en un volumen de $20 \mu 1$. El glioxal se asocia con el RNA e impide los enlaces entre los nucleótidos de citosina y guanina, de tal manera que las cadenas de RNA se mantienen libres de estructura secundaria para que posteriormente migren únicamente en función del tamaño. A continuación, se añadió a las muestras $8 \mu 1$ de tampón de carga $\left(50 \%\right.$ glicerol; $6 \mathrm{mM} \mathrm{Na} \mathrm{HPO}_{4} ; 4 \mathrm{mM}$ $\mathrm{NaH}_{2} \mathrm{PO}_{4} \cdot \mathrm{H}_{2} \mathrm{O} ; 0,1 \%$ azul de bromophenol), y se realizó la electroforesis en un gel de agarosa al $1,4 \%$ en tampón $6 \mathrm{mM} \mathrm{Na}_{2} \mathrm{HPO}_{4} ; 4 \mathrm{mM} \mathrm{NaH} \mathrm{PO}_{4} \cdot \mathrm{H}_{2} \mathrm{O}$. Las cadenas de RNA se separaron durante 6-7 h a $100 \mathrm{~mA}$.

\subsubsection{Transferencia del RNA a membranas de nylon}

Las cadenas de RNA separadas mediante electroforesis se transfirieron a membranas de nylon (Hybond-N, Amersham Pharmacia Biotech) utilizando como tampón de transferencia 20x SSC (6M NaCl; 0,6M citrato sódico dibásico pH: 7). La transferencia se llevó a cabo durante 16 h a temperatura ambiente. Después, la membrana se incubó a $80^{\circ} \mathrm{C}$ durante $1 \mathrm{~h} \mathrm{y}$, posteriormente, se trató con una fuente de luz UV de 312nm durante 20 seg (UV Stratalinker 2400, Stratagene) para unir covalentemente el RNA a la membrana.

\subsubsection{Hibridación de la membrana}

Las membranas se hibridaron con sondas de cDNA específicas marcadas con $[\alpha-$ $\left.{ }^{32} \mathrm{P}\right] \mathrm{dCTP}$. La hibridación del RNA unido a la membrana se realizó en tres etapas, de la misma manera que ha sido descrito previamente en el punto 3.1.5. para las membranas de Southern blot.

Las membranas se expusieron a películas de autorradiografía (Kodak-X-OmatAR) utilizando un intensificador de la señal (Reflection ${ }^{\mathrm{TM}}$ Intesifying Screen; DuPont). La exposición se realizó a $-70{ }^{\circ} \mathrm{C}$ durante un tiempo variable entre 8 h y 12 días. 
En los casos en que fue necesario realizar hibridaciones posteriores, se eliminó la radioactividad de las membranas mediante el lavado a $95^{\circ} \mathrm{C}$ durante 45 min en una solución al 0,1\% de SDS. Las hibridaciones posteriores se llevaron a cabo en las mismas condiciones.

\section{2. mediante PCR}

$\mathrm{Al}$ igual para genotipar los ratones MEFs Snai2 ${ }^{+/+}$y MEFs Snai2 ${ }^{-/-}$se usó el método de PCR para estudiar la expresión de Snai3 en las células MEFs control, MEFs p53 ${ }^{-{ }^{-}}$, MEFs Snai2 ${ }^{-/}$, MEFs p53 $3^{--}$;Snai2 $2^{--}$, en las líneas celulares Ba/F3 y MDCK y en los

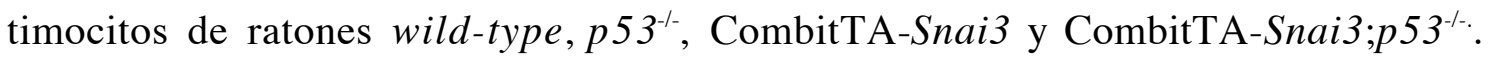
Utilizamos tanto el método de PCR de transcripción reversa (RT-PCR) normal como la RT-PCR semicuantitativa.

El sustrato de la reacción de PCR que utilizamos fue cDNA sintetizado a partir del RNA como se describe en el punto 1.1.2.. El cDNA así sintetizado se utilizó en las distintas reacciones de PCR.

\subsubsection{RT-PCR para Snai3}

Las amplificaciones se realizaron con $5 \mu 1$ de cDNA, 2,5 $\mu 1$ de tampón Thermophilic DNA poly 10x (Promega), 1,5mM $\mathrm{MgCl}_{2}, 200 \mu \mathrm{M}$ de la mezcla de nucleótidos dATP, dCTP, dGTP, dTTP (Amersham Pharmacia), 3pmoles de cada oligonucleótido y 0,25ul de la enzima Taq polimerasa (2,5U, Promega), en un volumen final de $25 \mu 1$.

\subsubsection{RT-PCR qualitativa}

Los oligonucleótidos utilizados fueron:

mSnai3-F: 5 - TGC TCT GCC TGC AAG GAG TT-3`

mSnai3-B: 5 - ATA TGC ATC TTG AGG GCA CC - 3`

El programa utilizado fue de 1 ciclo de $\left[94^{\circ} \mathrm{C}, 4 \mathrm{~min}\right], 35$ ciclos de $\left[94^{\circ} \mathrm{C}, 1 \mathrm{~min} /\right.$ $\left.58^{\circ} \mathrm{C}, 1 \mathrm{~min} / 72^{\circ} \mathrm{C}, 1 \mathrm{~min} 30 \mathrm{seg}\right]$ y un ciclo de $\left[72^{\circ} \mathrm{C}, 10 \mathrm{~min}\right]$.

Como control de carga se realizó una PCR de actina utilizando el siguiente programa: 1 ciclo de $\left[94^{\circ} \mathrm{C}, 4 \mathrm{~min}\right], 20$ ciclos de $\left[94^{\circ} \mathrm{C}, 1 \mathrm{~min} / 56^{\circ} \mathrm{C}, 1 \mathrm{~min} / 72^{\circ} \mathrm{C}, 1\right.$ $\min ]$ y un ciclo de $\left[72^{\circ} \mathrm{C}, 10 \mathrm{~min}\right]$. 


\subsubsection{RT-PCR semicuantitativa}

Para realizar la RT-PCR semicuantitativa se hicieron diluciones de 1/5 y 1/25 a partir del cDNA normal de cada muestra. Así se pueden estudiar mejor las diferencias en los niveles de la expresión de Snai3 mediante las concentraciones decrecientes de cDNA.

Los oligonucleótidos utilizados para esta PCR fueron:

mSnai3-SP5: 5'- GAC CGC TCC AAC CTG AG - 3'

mSnai3-3`UTR: 5 - CCT GGT GAT AAG TCT CCT CG - 3`

El programa utilizado fue de 1 ciclo de $\left[94^{\circ} \mathrm{C}, 4 \mathrm{~min}\right], 30$ ó 35 ciclos de $\left[94^{\circ} \mathrm{C}, 1 \mathrm{~min} /\right.$ $\left.58^{\circ} \mathrm{C}, 1 \mathrm{~min} / 72^{\circ} \mathrm{C}, 1 \mathrm{~min} 30 \mathrm{seg}\right] \mathrm{y}$ un ciclo de $\left[72^{\circ} \mathrm{C}, 10 \mathrm{~min}\right]$.

Como control de carga utilizamos GAPDH y los oligonucleótidos utilizados fueron:

GAPDH-F: 5'- GCC AAG GTC ATC CAT GAC AAC -3'

GAPDH-B: 5'- GCC TCC TTG GAG GCC ATG T - 3'

El programa utilizado fue de 1 ciclo de $\left[94^{\circ} \mathrm{C}, 4 \mathrm{~min}\right], 25$ ciclos de $\left[94^{\circ} \mathrm{C}, 1 \mathrm{~min} /\right.$ $\left.52^{\circ} \mathrm{C}, 1 \mathrm{~min} / 72^{\circ} \mathrm{C}, 1 \mathrm{~min} 30 \mathrm{seg}\right]$ y un ciclo de $\left[72^{\circ} \mathrm{C}, 10 \mathrm{~min}\right]$.

\section{Análisis de la expresión proteica}

Los extractos proteicos procedentes del cultivo de MEFs y de MDCK plaqueados y recogidos como se describe en el punto 5.3.1. y 5.3.2., y los extractos proteícos procedentes de los timos de ratones wild-type, $553^{-/}$, CombitTA-Snai3 y $p 53^{-/-}$ ;CombitTA-Snai3 se analizaron mediante Western blot. El protocolo que se siguió se describe a continuación.

\subsection{Obtención del extracto proteico total}

Los extractos proteicos de las células se obtuvieron a partir de cultivos celulares en placas. Éstas se lavaron dos veces con PBS y, posteriormente, se tripsinizaron. Las células tripsinizadas se pasaron a un tubo FALCON con medio de cultivo, obteniendo el tapón celular mediante centrifugación a temperatura ambiente durante 5 min a 1000 rpm. El tapón celular se lavó una veces con PBS y, a continuación, las células se resuspendieron en $1 \mathrm{ml}$ de PBS y se pasaron a tubos Eppendorf, donde se centrifugaron a $1000 \mathrm{rpm}$ a $4^{\circ} \mathrm{C}$ durante $5 \mathrm{~min}$.

El extracto proteico total se obtuvo, siempre en hielo, de la siguiente manera: $10^{7}$ células se resuspendieron en 200 4 l de tampón de lisis TNESV frío (50mM Tris pH 7,6; 
1\% Nonidet P-40 (BDH); 20 mM EDTA pH 8; 100 mM NaCl; 10 mM NaF (SIGMA); $1 \mathrm{mM} \mathrm{Na} \mathrm{VO}_{4}$ (SIGMA); $1 \mathrm{mM}$ Pefabloc (Roche); e inhibidores de proteasas (COMPLETE MINI; ROCHE)). Las muestras se incubaron durante 15 min en hielo, dándoles un vórtex cada 3-4 min. Finalmente, las muestras se centrifugaron durante 30 min a $4^{\circ} \mathrm{C}$ y $14000 \mathrm{rpm}$, y se recogió el sobrenadante, que será el que contenga el extracto proteico total.

La concentración de proteína de los extractos se determinó mediante colorimetría utilizando el "Protein Assay Kit" (BIO-RAD), empleando albúmina sérica bovina (BSA) para construir una recta patrón.

Para extraer las proteínas de los timocitos, obtenidos tras el sacrificio de los ratones, se machacó un trozo del tejido encima de un filtro de $0,45 \mu \mathrm{m}$ con PBS $1 \mathrm{x}+1 \%$ FCS, así filtrando las células y recogiendolas en un volumen de $15 \mathrm{ml}$, aproximadamente, de PBS 1x $+1 \%$ FCS. De ahí centrifugamos las células 5 min a una potencia de $1500 \mathrm{rpm}$ a $4^{\circ} \mathrm{C}$. El pellet de estas células fue resuspendido en tampón de lisis TNESV frío, y a continuación se siguió el mismo protocolo descrito para la obtención del extracto proteico total de las células.

\subsection{Electroforesis en geles SDS-PAGE}

Las fracciones proteícas fueron separadas por tamaño en geles SDS-PAGE (sodiumdodecyl sulfate-polyacrilamide gel) con un porcentaje de acrilamida del 8-12\%. A 20-30 $\mu \mathrm{g}$ de proteína en tampón de lisis TNESV se les añadió tampón de carga (50mM Tris pH 8,3; $25 \%$ glicerol; $10 \%$ SDS; $5 \% \beta$-mercaptoetanol; $0,1 \%$ azul de bromofenol) $(3 \mu 1$ tampón de carga/12 $\mu 1$ de extracto proteíco). Las muestras se desnaturalizaron durante 5 min a $100^{\circ} \mathrm{C}$, tras lo cual se mantuvieron $5 \mathrm{~min}$ en hielo. A continuación, se centrifugaron, se cargaron en el gel, y se sometieron a una diferencia de potencial de 85 Voltios durante $2 \mathrm{~h}$. El tampón que se utilizó para correr el gel fue 0,2M glicina; $25 \mathrm{mM}$ Tris; $0,1 \%$ SDS.

\subsection{Transferencia a membrana PVDF y marcaje con anticuerpos}

Una vez separadas por tamaño, las proteínas se transfirieron a una membrana PVDF (polyvinylidene fluoride) (Immobilon, Millipore) mediante una transferencia en húmedo, utilizando el sistema Mini Trans-BlotR, Electrophoretic transfer cell (BIORAD), que se dejó $16 \mathrm{~h} \mathrm{a} 4^{\circ} \mathrm{C}$ utilizando una diferencia de potencial de 35 Voltios. Como tampón de transferencia se utilizó 192mM glicina; 25mM Tris; $20 \%$ etanol. 
Posteriormente, la membrana se deshidrató durante 1 minuto en etanol y tras lavarla con tampón de lavado TBS-T (0,5\% Tween 20 (BIORAD); 10mM Tris-HCl pH 7,6; $150 \mathrm{mM} \mathrm{NaCl}$ ) se bloqueó a temperatura ambiente durante $2 \mathrm{~h}$ en solución de bloqueo (5\% Blotto (leche en polvo no grasa; Santa Cruz) disuelto en TBS-T).

Tras el bloqueo, la membrana se hibridó a temperatura ambiente durante $2 \mathrm{~h}$ con 1 $\mu \mathrm{g}$ (en 3ml de solución de bloqueo) del anticuerpo primario. Tras 3 lavados de 5 min y 3 lavados de 10 min con TBS-T, la membrana se incubó a temperatura ambiente durante $1 \mathrm{~h}$ con el anticuerpo secundario conjugado con peroxidasa de rábano diluído en solución de bloqueo. Tras 3 lavados de 5 min y 3 lavados de 10 min con TBS-T, las bandas reactivas se detectaron mediante quimioluminiscencia en filtros Hyperfilm ECL (Amershan Pharmacia Biotech), utilizando para su detección el sistema ECL plus (Amershan Pharmacia Biotech).

Los anticuerpos primarios utilizados fueron: anti- $\alpha$-Tubulin (T6074) (SIGMA) a una concentración 1/100000; anti-Vimentin (M0725) (DakoCytomation) a una concentración 1/5000; anti- $\beta$-Catenin (610153) (BD Bioscience) a una concentración 1/75000; anti- $\gamma$-Catenin (610253) (BD Bioscience) a una concentración 1/100000; antiE-Cadherin (610181) (BD Bioscience) a una concentración 1/100000; anti-p53 (Ab-3) (Oncogene) a una concentración 1/500; anti-Phospho-p53 (Ser15) (Cell Signaling Technology) a una concentración 1/5000; anti-Snai3 (H-18) (Santa Cruz) a una concentración 1/500; anti-Snai2 (G-18) (Santa Cruz) a una concentración 1/500; antip21 (F-5) (Santa Cruz) a una concentración 1/500; anti-Actin (I-19) (Santa Cruz) a una concentración 1/7500; anti-Adenovirus-2 E1A (M73) (Santa Cruz) a una concentración 1/500; anti-Cyclin D1 (72-13G) (santa cruz) a una concentración 1/5000; anti-Caspase-3 (Cell Signaling Technology) a una concentración 1/1000; anti-PUMA/bbc3 (P 4743) (SIGMA) a una concentración 1/10000.

Los anticuerpos secundarios utilizados, según el caso, fueron: Goat Anti-Mouse IgG $(\mathrm{H}+\mathrm{L})$-HRP Conjugate (BIORAD) a una concentración 1/5000; Anti-Goat IgG-HRP (Santa Cruz) a una concentración 1/5000; y Conjugated AffiniPure Goat Anti-Rabbit IgG (Jackson Inmunoresearch Laboratories) a una concentración 1/15000. 


\section{Análisis de la interacción proteína-cromatina mediante la inmunoprecipitación de cromatina (ChIP)}

La inmunoprecipitación de cromatina (ChIP) es un método bioquímico usado principalmente para determinar la interacción de proteínas con la cromatina. Esta técnica consiste en el uso de un anticuerpo que reconozca la proteína de interés no solamente en disolución sino también en la cromatina (Figura 60).

Para realizar el estudio de la ChIP utilizamos MEFs control tratados en ausencia y presencia de Doxorubicina durante 12 horas. De cada tipo celular se utilizaron tres placas Petri de $135 \mathrm{~mm}$ de diámetro estando a una confluencia de un $80 \%$. El protocolo que se siguió se describe a continuación.

Primero se tratan las células adherentes con formaldehído para que se fijen las interacciones proteína-proteína y las interacciones proteína-DNA. Para ello, añadimos el formaldehído a una concentración final de 1\% (formaldehído de 37\% (Fisher Cat\#BP521-500)) directamente en el medio de cultivo. Las células se incuban con el formaldehído durante 10 min a temperatura ambiente en agitación. Para parar la reacción de cross-linking se añade glicina $(0,125 \mathrm{M})$ y se incuban las células durante 5 min a temperatura ambiente también en agitación. A continuación, se aspira el medio de las placas, después se lavan las mismas dos veces con PBS 1x frío y se recogen todas las células en $5 \mathrm{ml}$ de PBS 1x frío (de cada placa) con un rascador (costar) y se pasan a un falcon de $50 \mathrm{ml}$ y se centrifugan durante $5-10 \mathrm{~min}$ a una potencia de $1500 \mathrm{rpm}$ a $4^{\circ} \mathrm{C}$. A continuación, se aspira el sobrenadante y se resuspende el pellet en 1,3ml de solución de lisis $(1 \%$ SDS + 50mM Tris-CL $(\mathrm{pH} \mathrm{8,1)} \mathrm{+} \mathrm{10mM} \mathrm{EDTA}(\mathrm{pH} \mathrm{8,0))} \mathrm{con} \mathrm{Pefabloc,} \mathrm{y}$ se incuba durante 10 min en hielo. A continuación, se transfiere la suspensión celular a un eppendorf y se sonica (diagonode BIORUPTOR) con un programa de $30 \mathrm{seg} \mathrm{ON}$ y $30 \mathrm{seg}$ OFF durante una hora, que es el tiempo para conseguir fragmentos de DNA de 500bp aproximadamente (durante la sonicación las muestras tienen que estar en frío). A continuación, se centrifuga la cromatina sonicada a $4^{\circ} \mathrm{C}$ durante 10 min a máxima potencia para bajar todos los fragmentos celulares. Después se transfiere el sobrenadante a un eppendorf nuevo, del cual se cogen $50 \mu 1$ de cromatina para chequear la eficiencia de la sonicación. Al resto de la muestra se le añaden $100 \mu$ l de proteína A pre-bloqueada y se incuba en agitación a $4^{\circ} \mathrm{C}$ durante 4 horas.

Después del pre-lavado se centrifuga la muestra a $4^{\circ} \mathrm{C}$ durante 2 min a una potencia de 3000rpm y se diluye el sobrenadante, en el que se encuentra la cromatina, 
con el buffer de dilución del ChIP 1x (1,1\% TritonX-100 + 0,01\%SDS + 167mM NaCl $+16,7 \mathrm{mM}$ Tris-Cl $(\mathrm{pH} \mathrm{8,1)}+1,2 \mathrm{mM}$ EDTA) con Pefabloc en un volumen final de $10 \mathrm{ml}$. De esta muestra se separan $100 \mu \mathrm{l}$ en un eppendorf nuevo para utilizarla como muestra Input. Del resto de la muestra se hacen aliquotas de $1 \mathrm{ml}$, de las cuales se utilizaron dos por cada anticuerpo:

1 x $100 \mu 1$ Input

$2 \times 1 \mathrm{ml}$ de cromatina sin anticuerpo

1 x 1ml de buffer de dilución de ChIP (Mock IP)

$2 \times 1 \mathrm{ml}$ de cromatina $+5 \mu \mathrm{g}$ de un anticuerpo inespecífico $(\mathrm{IgG})$

$2 \times 1 \mathrm{ml}$ de cromatina $+5 \mu \mathrm{g}$ de un anticuerpo específico

Se incuban toda la noche a $4^{\circ} \mathrm{C}$ en agitación.

$\mathrm{Al}$ día siguiente se añaden $30 \mu \mathrm{l}$ de la proteína A (pre-bloqueada) a cada muestra, menos a la muestra Input, y se incuban otras 4 horas a $4^{\circ} \mathrm{C}$ en agitación. A continuación se centrifugan todas las muestras durante 2 min a una potencia de $3000 \mathrm{rpm}$, seguido de 5 lavados a $4^{\circ} \mathrm{C}$ con los siguientes buffers: 1 lavado de 10 min con un buffer de baja concentración de sales $(0,1 \%$ SDS $+1 \%$ Triton $X-100+2 m M$ EDTA $+20 \mathrm{mM}$ Tris $\mathrm{pH}$ $8,1+150 \mathrm{mM} \mathrm{NaCl}), 1$ lavado de 10 min con un buffer de alta concentración de sales $(0,1 \%$ SDS $+1 \%$ Triton X-100 + 2mM EDTA + 20mM Tris PH 8,1 + 500mM NaCl), 1 lavado de 10 min con el buffer de $\mathrm{LiCl}(0,25 \mathrm{M} \mathrm{LiCl}+1 \% \mathrm{NP}-40+1 \%$ deoxycholate + $1 \mathrm{mM}$ EDTA + 10mM Tris pH 8,1) y por último 2 lavados de 10 min con TE $(\mathrm{pH} \mathrm{8,0)}$. Entre los lavados las muestras se centrifugan durante un minuto a una potencia de 3000rpm. Después del último lavado se resuspenden las muestras en $100 \mu l$ de buffer de elusión $\left(1 \% \mathrm{SDS}+0,1 \mathrm{M} \mathrm{NaHCO}_{3}\right)$, se vortexean al máximo durante 30 seg y después se agitan a temperatura ambiente durante $15 \mathrm{~min}$. A continuación, se centrifugan las muestran a temperatura ambiente durante 2 min a una potencia de 3000rpm para bajar el pellet. El sobrenadante se guarda. Después se repiten los últimos pasos (resuspender el pellet, vortex y lavar) y se juntan los dos sobrenadantes. A estas muestras se les añaden $12 \mu 1$ de $5 \mathrm{M} \mathrm{NaCl}$ (concentración final: $0,3 \mathrm{M} \mathrm{NaCl}$ ) y se incuban toda la noche a $65^{\circ} \mathrm{C}$ para revertir el cross-linking y así liberar el DNA. También se añaden $100 \mu$ l de buffer de elución más $12 \mu 1$ de $5 \mathrm{M} \mathrm{NaCl}$ a la muestra Input y se incuba con las otras muestras toda la noche a $65^{\circ} \mathrm{C}$.

El tercer día se purificó el DNA mediante la extracción con 1/2 volumen de

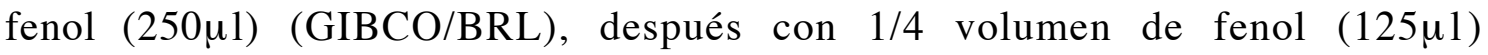


(GIBCO/BRL)/1/4 volumen de cloroformo (125 $\mu$ l) (Merck) y posteriormente con 1/2 volumen de cloroformo $(250 \mu 1)$ (Merck). A continuación, se pasó la fase acuosa (superior) a dos volúmenes de etanol absoluto ( $1 \mathrm{ml}$ ) (Merck), y se dejaron a $-20^{\circ} \mathrm{C}$ durante toda la noche. Al día siguiente las muestras se centrifugaron durante $30 \mathrm{~min}$ a máxima potencia y se lavaron con $70 \%$ de etanol. El pellet se resuspendió en $100 \mu 1$ de agua bidestilada. Estas muestras fueron utilizadas para poner las PCR's de interés. Las secuencias específicas de DNA inmunoprecipitadas son entonces amplificadas por PCR para determinar si han sido o no enriquecidas en las muestras correspondientes para cada anticuerpo (Kuo and Allis, 1999).

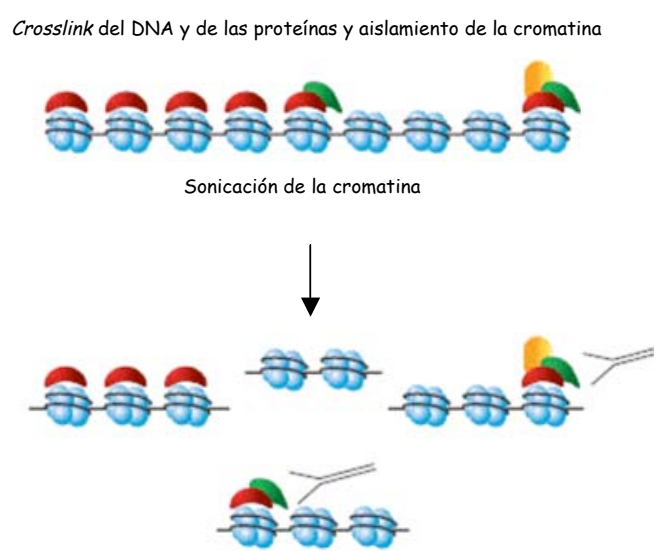

Inmunoprecipitación, crosslink reverso, purificación del DNA

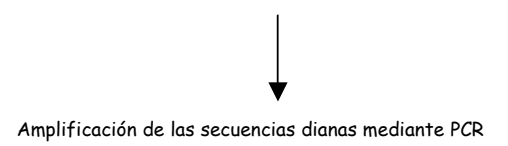

Figura 60: Inmunoprecipitación de la cromatina (ChIP). Las proteínas unidas al DNA se fijan con formaldehído. La cromatina se aísla y el DNA, junto a las proteínas unidas, se fragmenta por sonicación. Las proteínas unidas al DNA son inmunoprecipitadas usando anticuerpos específicos para aislar el complejo formado con el DNA. Después se revierte el entrecruzamiento para liberar el DNA y mediante $P C R$ se amplifican las secuencias de interés.

Los anticuerpos $(5 \mu \mathrm{g})$ específicos para los estudios fueron:

anti-Snai2 (G-18) (Santa Cruz)

anti-p53 (DO-1) (Santa Cruz)

Los oligos utilizados para las PCR's fueron los siguientes:

HPRT-F: 5'-AGGAGTCCTGTTGATGTTGCCAGT-3'

HPRT-R: 5'-GGAAATCGAGAGCTTCAGACTCGT-3'

mSnai3 prom (p53)-F: 5'-GCTGAAGGAGCAACACAGCGTG-3'

mSnai3 prom (p53)-R: 5'-ACAGGCCAGCAGGCTTCATGCA-3'

mSnai3 intrón1 A (p53)-F: 5'-GTCTCCTTACAGAGGAGGTAGA-3'

mSnai3 intrón A (p53)-R: 5'-GTGCTCTCCAAGTGCAATCTAAGG-3'

mSnai3 intrón 1 B (p53)-F: 5'-GAGCAATATGTCTGGTAGGGAG-3' 
mSnai3 intrón1 B (p53)-R: 5'-CATATGGGCAGTGTGCACACGAG-3'

mSnai3 prom (Snai2)-F: 5'-GTCGGTGCGTGACCATGACGC-3'

mSnai3 prom (Snai2)-R: 5'-GATTACCGACTGCAGAGTCTGGC-3'

mSnai3 intrón1 (Snai2)-F: 5'-GCTGGAGGCAGCTGGGAAGTC-3'

mSnai3 intrón1 (Snai2)-R: 5'-CATGCCCGAATCTTCTGAAGCAG-3'

\section{Ensayo Luciferasa}

Para estudiar la actividad del promotor de Snai3 hicimos uso de un vector que contiene el cDNA codificante para la proteina luciferasa (firefly luciferase en inglés), de manera que se puede detectar la activación o represión del promotor clonado en este vector, que en nuestro caso es el promotor de Snai3 (punto 1.5.).

Para realizar el análisis de la actividad del promotor de Snai3 utilizamos los pellets de las células que obtuvimos mediante la transfección $\mathrm{CaCl}_{2}$ (ver punto 5.5.)

El estudio se realizó utilizando el Kit "Dual-LuciferaseTM Reporter Assay System, 10-Pack" (Promega E1960), y el protocolo se describe a continuación.

El pellet de las células (guardado a $-80^{\circ} \mathrm{C}$ ) se resuspendió en $200 \mu 1$ del Passive Lysis Buffer (PLB) 1x, que se prepara en el momento de usarlo a partir de un stock 5x. A continuación, se congelaron los pellets resuspendidos a $-80^{\circ} \mathrm{C}$ y después se descongelaron a $37^{\circ} \mathrm{C}$ (5 minutos de cada proceso). Esto se repitió dos veces para conseguir una buena ruptura de las células. A continuación, las muestras se centrifugaron un minuto a temperatura ambiente a máxima potencia y después se metieron en hielo. De ahí se cogieron $20 \mu 1$ de las muestras y se añadieron en un eppendorf que contenía $100 \mu$ l de LARII. A continuación, se midió el valor de luciferasa de cada muestra utilizando el Luminómetro Berthold (Detection system) FB12. Una vez obtenido el valor de Luciferasa, se añadieron $100 \mu 1$ de Stop\&Glo Solution (1 vol 50x Stop/Glo + 49 vol Stop/Glo buffer) en el mismo eppendorf, y se midió de nuevo el valor en el Luminómetro, para medir en esta ocasión el valor de Renilla, que nos mide la eficiencia de la transfección.

El valor real RLU (relative light units) se calculó dividiendo el valor de Luciferasa entre el valor de Renilla. 


\section{Estudios de Apoptosis}

\section{1. mediante FACS}

Los cambios en la membrana plasmática de la superficie celular son una de las primeras características de las células que están sufriendo apoptosis. En las células apoptóticas, el fosfolípido de membrana fosfatidil-serina se transloca de la cara interna a la cara externa de la membrana plasmática, quedando así expuesta al entorno celular. La Annexin-V se une con gran afinidad a la fosfatidil-serina, y es ,por tanto, un indicador muy sensible para identificar las células que están sufriendo apoptosis porque la exposición de la fosfatidil-serina ocurre pronto en el proceso apoptótico (Martin et al., 1995). El marcaje con IP, que se une a DNA, va a permitir diferenciar las células vivas de las células muertas. Esto es debido a que las células vivas con membranas intactas excluden el IP, mientras que las membranas de las células muertas o dañadas son permeables al IP, que así podrá entrar en la célula y marcar el DNA.

Los estudios de apoptosis se llevaron a cabo como ya ha sido descrito previamente (McCurrach and Lowe, 2001). El protocolo utilizado se describe a continuación.

Se plaquearon $2 \times 10^{5}$ células/pocillo en placas de seis pocillos, cuatro pocillos de cada tipo celular, $24 \mathrm{~h}$ antes de añadir el agente para inducir apoptosis. Una vez transcurridas las $24 \mathrm{~h}$, se sustituyó el medio de dos pocillos de cada tipo celular por medio fresco, y el de los otros dos pocillo por medio fresco suplementado con $0,2 \mu \mathrm{g} / \mathrm{ml}$ de doxorubicina, y se incubaron nuevamente durante $24 \mathrm{~h}$. Transcurrido ese tiempo se procedió a realizar el estudio de apoptosis. Para ello, el sobrenadante de cada pocillo se recogió en un tubo FALCON con medio fresco, y también en él se recogieron las células tripsinizadas del pocillo correspondiente. Se procedió al contaje de las células de cada FALCON, se centrifugaron a $1000 \mathrm{rpm}$ durante 5 min a temperatura ambiente para obtener el botón celular, y a continuación se resuspendieron en $1 \mathrm{ml}$ de PBS frío y se pasaron a tubos Eppendorf que se centrifugaron a $1000 \mathrm{rpm}$ durante $5 \mathrm{~min}$ a $4^{\circ} \mathrm{C}$. A continuación se resuspendieron las células en un buffer de unión (10mM Hepes/ $\mathrm{NaOH}$ $\mathrm{pH} 7,4,140 \mathrm{mM} \mathrm{NaCl}, 2,5 \mathrm{mM} \mathrm{CaCl}$ ) de manera que la concentración final fuera de $2 \times 10^{6}$ células $/ \mathrm{ml}$ de buffer. La muerte celular por apoptosis fue medida mediante el marcaje de $100 \mu 1$ de cada tipo celular con $2 \mu 1$ de Annexin V-FITC (BD Pharmingen ${ }^{\mathrm{TM}}$; BD Biosciences) y ioduro de propidio $(0,5 \mu \mathrm{g} / \mathrm{ml})$ (IP; Sigma) durante $15 \mathrm{~min}$ en 
oscuridad. Para el análisis de las muestras se utilizó un citómetro de flujo FACScan (Becton Dickinson) y el programa de análisis Paint a Gate 3.0.2 PPC (Nov 1999). Las células positivas para Annexin-V (positivas o negativas para IP) se contaron como apoptóticas.

\section{2. mediante marcaje in situ del DNA fragmentado o técnica de TUNEL (TdT-} mediated dUTP Nick-End Labeling)

Para la realización de las diferentes determinaciones se utilizaron los bloques de parafina de las piezas de órganos de ratones sacrificados (ver punto 4), obtenidos por el Departamento de Anatomía Patológica de Hospital Clinico de Salamanca.

La valoración de la apoptosis por el método de marcaje in situ del DNA fragmentado o técnica de TUNEL tiene su fundamento en la detección de la rotura del DNA internucleosomal, típica de la apoptosis, en secciones de tejido incluidas en parafina. Presenta como ventaja la detección de las células de apoptosis en estadios más precoces que la hematoxilina-eosina.

Se pone de manifiesto los extremos $3 `-\mathrm{OH}$ libres que se generan en la fragmentación de DNA, incorporando núcleotidos marcados a dichos extremos mediante la acción del enzima transferasa terminal (TdT).

Para realizar este método utilizamos el KIT “In situ Cell Death Detection Kit, AP" (Roche).

Inicialmente, se desparafinaron las secciones en xileno y se hidrataron mediante concentraciones decrecientes de alcohol etílico $(100 \%, 96 \%, 70 \%)$ y agua destilada. A continuación, se desproteinizaron durante 15 minutos, mediante incubación con proteinasa K (SIGMA) $(20 \mu \mathrm{g} / \mathrm{ml})$ en una solución de $10 \mathrm{nM}$ de Tris-Hcl pH 7,5. Después se aclaron las secciones 4 veces en PBS.

A continuación, se preparó la mezcla de reacción de TUNEL, 50ul de Enzyme solution (vial 1) más $450 \mu 1$ de Label solution (vial 2) para cada 10 muestras. Esta mixtura se tiene que mezclar bien para equilibrar los componentes. Las muestras fueron preparadas inmediatamente antes de usar. Después, las muestras fueron aplicadas con $50 \mu 1$ de la mezcla de TUNEL y seguidamente incubadas 60 minutos en oscuridad en una cámera humidificadora a una temperatura de $60^{\circ} \mathrm{C}$. Para asegurar un reparto homogéneo de la mezcla y evitar pérdidas por evaporación, las muestras deberían estar 
cubiertas con parafilm o con un cubre durante la incubación. Después las secciones fueron aclaradas 6 veces con PBS.

En este paso analizamos las muestras en una gota de PBS bajo el microscopio de fluorescencia, después de marcar el núcleo con DAPI (4.6 Diamidino-2Phenylindole) (SIGMA) $(0.1 \mathrm{mg} / \mathrm{ml}$ en 2 XSSC) 2 minutos en oscuridad a temperatura ambiente para visualizar todas las células. Usamos una longitud de onda de excitación entre 450550nm y de detección de 515-565nm (verde).

Los controles positivos se realizaron incubando una sección de los tejidos del ratón control (wild-type) 10 minutos con DNasa I recombinante $(3000 \mathrm{U} / \mathrm{ml}-3 \mathrm{U} / \mathrm{ml}$ en $50 \mathrm{mM}$ Tris-Hcl, $\mathrm{pH} 7,5,10 \mathrm{mM} \mathrm{MgCl} 2,1 \mathrm{mg} / \mathrm{ml} \mathrm{BSA}$ ) a una temperatura de $15-25^{\circ} \mathrm{C}$ para inducir roturas en el DNA. Después se trató esta muestra igual que el resto de las muestras a partir de aplicar con la mezcla de la reacción de TUNEL. El control negativo resultaron de practicar el ensayo en aplicar la muestra sólo con $50 \mu 1$ de Label Solution (vial 2), que quiere decir en ausencia de la encima terminal transferasa.

\section{Estudio del ciclo celular}

Para estudiar el ciclo celular y así detectar las células en las diferentes fases del ciclo, utilizamos Ioduro de propidio (IP) y Bromodeoxiuridina (BrdU) (Becton Dickinson). BrdU es un análogo del nucleótido timidina (Dolbeare et al., 1983), que va a ser incorporado específicamente en el DNA en lugar de la timidina, con lo que vamos a separar así las células que están sintetizando DNA (fase S). El marcaje con IP nos permite diferenciar entre las células con 2 n en G0/1 y las células con 4n en G2/M. El protocolo utilizado se describe a continuación:

Se plaquearon $1 \times 10^{6}$ células por placa de $10 \mathrm{~cm}$ de diámetro en $10 \mathrm{ml}$ medio DMEM (4 placas por cada tipo celular) suplementado con $10 \%$ de FCS, 2mM LGlutamina, $50 \mu \mathrm{g} / \mathrm{ml}$ estreptomicina y $50 \mathrm{U} / \mathrm{ml}$ penicilina $12 \mathrm{~h}$ antes de añadir el agente para inducir el daño en el DNA. Una vez transcurridas las 12 h, se sustituyó el medio de dos placas de cada tipo celular por medio fresco, y el de los otros dos placas por medio fresco suplementado con $0,2 \mu \mathrm{g} / \mathrm{ml}$ de doxorrubicina, y se incubaron nuevamente

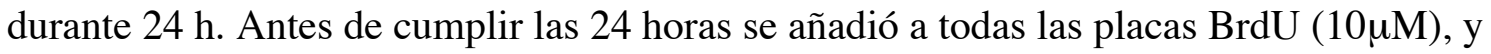
se incubaron de nuevo 2-4 horas. Transcurrido ese tiempo se procedió a recoger las células para realizar el estudio del ciclo celular. Para ello, se aspiró el sobrenadante de cada placa, se lavaron una vez con $5 \mathrm{ml}$ de PBS 1x, y después se tripsinizaron con $2 \mathrm{ml}$ 
de tripsina durante $5 \mathrm{~min}$. A continuación, se recogieron las células de las dos placas de cada tipo celular en un tubo FALCON con medio fresco, se procedió al contaje de las células de cada FALCON, y se centrifugaron a $1000 \mathrm{rpm}$ durante $5 \mathrm{~min}$ a temperatura ambiente seguido de un lavado con 10ml de PBS 1x frío, y se centrifugaron nuevamente a $1000 \mathrm{rpm}$ durante $5 \mathrm{~min}$ a temperatura ambiente para obtener el botón celular. A continuación, se resuspendió el pellet en PBS frío de manera que la concentración final fuera $2 \times 10^{6}$ células/ml. Después, se mezcló cada FALCON de forma vigorosa (poniendo el tubo en un vortex a baja velocidad) y de forma simultánea añadiendo gota a gota $100 \mu 1$ de etanol $70 \%$ frío para fijar las células, y se dejó incubar durante 30 min en hielo. (En este paso se pueden guardar las muestras hasta varios meses a $-20^{\circ} \mathrm{C}$.) A continuación, se añadieron $2 \mathrm{ml}$ de HCL $(4 \mathrm{~N})+0,5 \%$ de Triton-X a la suspensión fijada para desnaturalizar el DNA, se mezcló suavemente y se dejó incubar durante 30 min a temperatura ambiente. Después se centrifugaron las células a $1000 \mathrm{rpm}$ durante $5 \mathrm{~min}$ a temperatura ambiente, se aspiró el sobrenadante y se resuspendió el pellet en $1 \mathrm{ml}$ de $\mathrm{Na}_{2} \mathrm{~B}_{4} \mathrm{O}_{7} \mathrm{pH} 8,5(0,1 \mathrm{M})$ y se pasaron a tubos Eppendorf que se centrifugaron a 1000 rpm durante $5 \min$ a $4^{\circ} \mathrm{C}$. A continuación, se aspiró el sobrenadante con cuidado y se resuspendió el pellet en 50 $\mu 1$ de PBS 1x +0,5\% Tween $20+1 \%$ BSA. A estas muestras fueron añadidas $20 \mu 1$ de $\alpha$-BrdU-FITC (BD Pharmingen ${ }^{\text {TM }}$; BD Biosciences) y $20 \mu 1$ de RNasa A $(10 \mathrm{mg} / \mathrm{ml})$ y se incubaron durante una hora a temperatura ambiente en oscuridad. Después se centrifugaron a $1000 \mathrm{rpm}$ durante $5 \mathrm{~min}$, se aspiró el sobrenadante y se lavaron con $1 \mathrm{ml}$ de PBS $1 \mathrm{x}+0,5 \%$ Tween $20+1 \%$ BSA. Finalmente se centrifugaron a $1000 \mathrm{rpm}$ durante $5 \mathrm{~min}$ a temperatura ambiente, se aspiró el sobrenadante y se resuspendió el pellet en $1 \mathrm{ml}$ de IP $(5 \mu \mathrm{g} / \mathrm{ml})$ (Sigma) diluido en PBS. Para el análisis de las muestras se utilizó un citómetro de flujo FACScan (Becton Dickinson) y el programa de análisis Paint a Gate 3.0.2 PPC (Nov 1999).

\section{Localización subcelular de la proteína de fusión GFP-Snai3 mediante microscopía confocal. Inmunofluoresecencia para GFP}

Las células en cultivo, las U2OS y las SaoS-2, transfectadas con la proteína de fusión GFP-Snai3 o con el vector vacío se lavaron con $5 \mathrm{ml}$ de PBS, se tripsinizaron durante 5 min a $37^{\circ} \mathrm{C}$ con $3 \mathrm{ml}$ de tripsina/placa, y se recogieron en tubos Falcon con $20 \mathrm{ml}$ de medio. A continuación, se lavaron dos veces con PBS 1x + 10\% FCS y el pellet se resuspendió en $1 \mathrm{ml}$ de PBS 1x + 10\% FCS. De esta suspensión se llevó 1 gota a cada 
pocillo de un slide previamente tratado con poli-L-Lisina $(1 \mu \mathrm{g} / \mu \mathrm{l})$ (Poly-L-Lysine Hydrobron) y se realizó una incubación de 30 minutos a temperatura ambiente. Después de lavar 2 veces con PBS 1x + 10\% FCS (5 min de cada lavado), el slide se sumergió en paraformaldehído (PFA) al 4\% durante 15-30 minutos. Tras la fijación se lavó nuevamente 2 veces con PBS 1x + 10\% FCS. A continuación, se añadió una gota de Ioduro de propidio (IP) $(0,3 \mu \mathrm{g} / \mathrm{ml})$ diluido en PBS $1 \mathrm{x}$ y se incubó durante un min en oscuridad, se lavó otra vez 2 veces con PBS 1x + 10\% FCS, se dejó secar y finalmente se tapó con un cubre añadiendo previamente una gota en cada dos pocillos de Vectashield. La visualización de GFP se realizó en un microscopio confocal de flurescencia aplicando una excitación de 488nm con láser de argón.

\section{Estudios anatomo-patológicos}

\subsection{Extracción de órganos}

De forma sistemática, además de los tumores, se aislaron los distintos órganos de los ratones transgénicos analizados (hígado, bazo, corazón, pulmón, riñón, médula ósea, timo e intestino delgado), y se fijaron en formaldehído al $4 \%$ tamponado a $\mathrm{pH} 7$ y estabilizado con metanol DC (Panreac) durante al menos $24 \mathrm{~h}$. En el caso del hueso, la fijación se realizó con una solución de formaldehído al 4\% y ácido nítrico al 6\% (Panreac), con lo que se consigue la descalcificación del hueso de forma que se permite que estos tejidos puedan ser cortados por el microtomo.

\subsection{Inclusión de los órganos en parafina}

Una vez fijados, y con el fin de aumentar la dureza de las muestras para posteriormente obtener cortes de los diferentes órganos y tejidos, éstos fueron incluídos en parafina. Para ello, las muestras se procesaron en el Tissue-tek VIP (Miles Scientific), un sistema en el que tras varios pasos, las muestras son embebidas en parafina líquida. Al ser la parafina un medio hidrófobo, en primer lugar las muestras se deshidrataron tratándolas con solventes orgánicos. Las muestras se trataron sucesivamente a $40^{\circ} \mathrm{C}$ durante $30 \mathrm{~min}$ en formol al 10\% (dos baños), etanol al 70\%, etanol al 80\%, etanol al 90\%, etanol absoluto (tres baños) y xileno (2 baños). Una vez deshidratadas y fijadas, las muestras se incluyeron en parafina mediante tres baños de 30 min a $60^{\circ} \mathrm{C}$ en parafina (Histosec; MERCK). Por último, las muestras se montaron en un molde metálico con parafina líquida, que se dejó solidificar hasta que obtuvimos los bloques con las muestras listas 
para ser cortados en el microtomo (Leica RM 2135). Se realizaron cortes de $4 \mu \mathrm{m}$ de los diferentes tejidos.

\subsection{Desparafinado y re-hidratación de las muestras}

Una vez hechos los cortes de las muestras y, antes de proceder a la tinción de los mismos, éstos se desparafinaron y rehidrataron, para que el tejido estuviera accesible y reactivo a los diferentes colorantes. Para desparafinar los cortes, éstos se incubaron a $80^{\circ} \mathrm{C}$ durante $20 \mathrm{~min}$ en una estufa seca para licuar la parafina $\mathrm{y}$, posteriormente, se realizaron 3 baños sucesivos de 10 min a temperatura ambiente en xilol (Merck) para disolverla. A continuación, se rehidrataron los tejidos tratándolos con solventes orgánicos, pero de forma inversa al tratamiento de deshidratación, es decir, los cortes se trataron sucesivamente a temperatura ambiente durante 5 min con etanol absoluto, etanol al $90 \%$, etanol al $80 \%$ y etanol al $70 \%$. Por último, los cortes se lavaron abundantemente con agua y se dejaron secar, estando ya listos para la tinción histológica.

\subsection{Tinción con hematoxilina-eosina}

La tinción con hematoxilina-eosina permite visualizar de manera general el estado de los tejidos, y por ello es la tinción más utilizada. Este método consta de una fase inicial en la que se colorean los núcleos celulares con hematoxilina, y una segunda fase de contraste citoplasmático y de tinción de los componentes extracelulares con la eosina. El procedimiento técnico es el que se detalla a continuación: los cortes desparafinados y rehidrados se sumergieron en hematoxilina de Carazzi (Merck) durante 7 min a temperatura ambiente y, tras lavarlos abundantemente con agua, se pasaron a una solución de etanol al 80\%/ácido acético al 35\% (200:1) durante 3 seg con el fin de decolorar y limpiar el tejido. A continuación, tras lavar los cortes abundantemente con agua, se sumergieron en una solución acuosa con carbonato de litio a saturación (Merck) durante $3 \mathrm{seg}$, lo que va a hacer que el tejido coja un color azul intenso. Tras lavar los cortes con agua, se tiñeron con eosina (Merck) durante 2 min y, finalmente, se deshidrataron con un tratamiento sucesivo con solventes orgánicos: etanol al $70 \%$, etanol al $80 \%$, etanol al $90 \%$, etanol absoluto durante $3 \mathrm{seg}$, y con una solución xilol/etanol (1:1) y xilol durante $10 \mathrm{seg}$. Por último, las muestras fueron montadas con el cubreobjetos y un medio especial para ello (EUKITT, Panreac). 


\subsection{Definición anatomo-patológica y fotografiado de las muestras}

Una vez teñidas las muestras, fueron analizadas con el asesoramiento de los patólogos humanos del Departamento de Anatomía Patológica del Hospital Universitario de Salamanca y, muy especialmente, de la Doctora Teresa Flores Corral. El diagnóstico patológico se basa en la clasificación de tumores de la organización mundial de la salud (Jaffe et al., 2001).

De la misma manera, las fotografías de las muestras histológicas de los ratones en estudio se han realizado con el asesoramiento del mismo Departamento de Anatomía Patológica, y se utilizó una cámara de color marca Olympus (DP70) adaptada a un microcopio Olympus (BX41).

\section{Curvas de superviviencia de ratones}

Para realizar una curva de supervivencia tanto de ratones CombiTA-Snai3 frente a ratones control como de ratones CombitTA-Snai3;p53 ${ }^{-/-}$y CombitTA-Snai3;p53 ${ }^{+/-}$ frente a ratones $p 53^{-/}$, que nos permitiera determinar la vida media asociada a cada genotipo, se utilizó el método de Kaplan-Meier (Kaplan and Meier, 1958). 
ABREVIATURAS 
$\begin{array}{ll}\%: & \text { Porcentaje } \\ { }^{\circ} \mathrm{C}: & \text { Grados Celius }\end{array}$

Apaf-1: del inglés, Apoptosis protease-activating factor-1

aprox: aproximadamente

BER: $\quad$ reparación por escisión de bases

BrdU: $\quad$ Bromo-deoxi-Uridina

BSA: del inglés, Bovine Serum Albumine, albúmina sérica bovina

CDK: quinasa dependiente de ciclinas

cDNA: DNA codificante

ChIP: del inglés, chromatin immunoprecipitation

cm: centímetros

CMV: $\quad$ citomegalovirus

c-terminal: carbixi-terminal

DAPI: del inglés, 4, 6DiAmidin-2-Phenyl-Indole, 4,6 diamidino-2-fenil-indol

dATP: $\quad 2$ - deoxiadenosina 5 - trifosfato

dCTP: $\quad 2^{\prime}$ - deoxicitosina $5^{\prime}$ - trifosfato

dGTP: $\quad 2{ }^{\prime}$ - deoxiguanosina 5 'trifosfato

dTTP: $\quad 2^{\prime}$ - deoxitimidina $5{ }^{\prime}$-trifosfato

DMEM: $\quad$ del inglés, Dulbecco’s Modified Eagle Médium, Medio de cultivo Eagle modificado por Dulbecco

DNA: ácido deoxirribonucleíco

DTT: ditiotreitol

EDTA. del inglés, Ethylen-Diamin-Tetra-Acetate, Etilén-diamino-tetra-acetato

EMT: del inglés, epitelio mesenchyme transition, transición epitelio mesenquimal

FACS: del inglés, Flow-activated cell sorter, Separación celular dependiente de fluorescencia

Fig.: $\quad$ Figura

GFP: del inglés, green fluorescence protein, proteína verde fluorescente

GSK3 $\beta$ : del inglés, Glycogen Sintetase Kinase $3 \beta$, quinasa de la glucógeno sintetasa $3 \beta$

h: hora

HR: $\quad$ recombinación homóloga

IP: $\quad$ Ioduro de propidio

$\mathrm{Kb}: \quad$ kilobases

mM, M: molar, milimolar

$\mathrm{mA}$ miliamperios

MDCK: del inglés, Madin-Darbin canine kidney

MEFs: del inglés, mouse embryonic fibroblasts, fibroblastos embrionario de ratón 
min: $\quad$ minuto

$\mathrm{ml}, \mathrm{mm}, \mathrm{nm} \quad$ mililitro, milimetro, nanómetros

MMR: reaparción de apareamientos erróneos

mut: $\quad$ Mutación en el gen descrito

$\mu \mathrm{g}, \mu \mathrm{l}, \mu \mathrm{M} \quad$ microgramo, microlitro, micromolar

NER: $\quad$ reparación por escisión de núcleotido

NHEJ: reparación mediante la unión de terminales no homólogas

N-terminal: amino-terminal

OD: $\quad$ densidad óptica

pb: $\quad$ pares de bases

PCR: $\quad$ del inglés, polymerase chain reaction, reacción en cadena de la polimerasa

pmoles: $\quad$ picomoles

RB: $\quad$ Retinoblastoma

RE: del inglés, responsive element

RNA: $\quad$ ácido ribonucleíco

rpm: revoluciones por minuto

seg: $\quad$ segundo

TBE: $\quad$ del inglés, Tris-Borate-EDTA, Tris-borato-EDTA

TE: $\quad$ Tris-EDTA

Tris: $\quad$ Tris-(hidroximetil-aminometano

TUNEL: $\quad$ del inglés, $\underline{T} d T$ - mediated d $\underline{U} T P$ nick $\underline{\text { end }}$ labelling, Marcaje de extremos con dUTP mediado por la enzima TdT

$\mathrm{U}: \quad$ unidades

UV: $\quad$ ultravioleta

VAL: $\quad$ Valina

wt: $\quad$ el inglés, wild-type, forma nativa 
BIBLIOGRAFÍA 
Acloque, H., Thiery, J. P., and Nieto, M. A. (2008). The physiology and pathology of the EMT. Meeting on the epithelial-mesenchymal transition. EMBO reports 9, 322326.

Agami, R., and Bernards, R. (2000). Distinct initiation and maintenance mechanisms cooperate to induce G1 cell cycle arrest in response to DNA damage. Cell 102, 55-66.

Agarwal, M. L., Agarwal, A., Taylor, W. R., and Stark, G. R. (1995). p53 controls both the G2/M and the G1 cell cycle checkpoints and mediates reversible growth arrest in human fibroblasts. Proceedings of the National Academy of Sciences of the United States of America 92, 8493-8497.

Ahn, J., and Prives, C. (2001). The C-terminus of p53: the more you learn the less you know. Nature structural biology $8,730-732$.

Alao, J. P. (2007). The regulation of cyclin D1 degradation: roles in cancer development and the potential for therapeutic invention. Molecular cancer 6, 24.

Alberga, A., Boulay, J. L., Kempe, E., Dennefeld, C., and Haenlin, M. (1991). The snail gene required for mesoderm formation in Drosophila is expressed dynamically in derivatives of all three germ layers. Development (Cambridge, England) 111, 983-992.

Appella, E., and Anderson, C. W. (2001). Post-translational modifications and activation of p53 by genotoxic stresses. European journal of biochemistry / FEBS 268, 2764-2772.

Ashcroft, M., and Vousden, K. H. (1999). Regulation of p53 stability. Oncogene 18, 7637-7643.

Ashraf, S. I., Hu, X., Roote, J., and Ip, Y. T. (1999). The mesoderm determinant snail collaborates with related zincfinger proteins to control Drosophila neurogenesis. The EMBO journal 18, 6426-6438.

Attardi, L. D, de Vries, A, and Jacks, T. (2004). Activation of the p53-dependent G1 checkpoint response in mouse embryo fibroblasts depends on the specific DNA damage inducer. Oncogene 23, 973-980.

Azzam, E. I., de Toledo, S. M., Pykett, M. J., Nagasawa, H., and Little, J. B. (1997). CDC2 is down-regulated by ionizing radiation in a p53-dependent manner. Cell Growth Differ 8 , 1161-1169.

Barak, Y., Juven, T., Haffner, R., and Oren, M. (1993). mdm2 expression is induced by wild type p53 activity. The EMBO journal 12, 461-468.

Barrallo-Gimeno, A., and Nieto, M. A. (2005). The Snail genes as inducers of cell movement and survival: implications in development and cancer. Development (Cambridge, England) 132, 3151-3161

Batlle, E., Sancho, E., Franci, C., Dominguez, D., Monfar, M., Baulida, J., and Garcia De Herreros, A. (2000). The transcription factor snail is a repressor of E-cadherin gene expression in epithelial tumour cells. Nature cell biology 2 , 84-89.

Bermejo-Rodriguez, C., Perez-Caro, M., Perez-Mancera, P. A., Sanchez-Beato, M., Piris, M. A., and Sanchez-Garcia, I. (2006). Mouse cDNA microarray analysis uncovers Slug targets in mouse embryonic fibroblasts. Genomics 87, 113118 .
Blanco, M. J., Moreno-Bueno, G., Sarrio, D., Locascio, A., Cano, A., Palacios, J., and Nieto, M. A. (2002). Correlation of Snail expression with histological grade and lymph node status in breast carcinomas. Oncogene 21, 3241-3246.

Bode, A. M., and Dong, Z. (2004). Post-translational modification of p53 in tumorigenesis. Nat Rev Cancer 4, 793-805.

Bolos, V., Peinado, H., Perez-Moreno, M. A., Fraga, M. F., Esteller, M., and Cano, A. (2003). The transcription factor Slug represses E-cadherin expression and induces epithelial to mesenchymal transitions: a comparison with Snail and E47 repressors. Journal of cell science 116, 499-511.

Boulay, J. L., Dennefeld, C., and Alberga, A. (1987). The Drosophila developmental gene snail encodes a protein with nucleic acid binding fingers. Nature 330, 395-398.

Bunz, F., Dutriaux, A., Lengauer, C., Waldman, T., Zhou, S., Brown, J. P., Sedivy, J. M., Kinzler, K. W., and Vogelstein, B. (1998). Requirement for p53 and p21 to sustain G2 arrest after DNA damage. Science (New York, NY 282, 1497-1501.

Cano, A., Perez-Moreno, M. A., Rodrigo, I., Locascio, A., Blanco, M. J., del Barrio, M. G., Portillo, F., and Nieto, M. A. (2000). The transcription factor snail controls epithelialmesenchymal transitions by repressing E-cadherin expression. Nature cell biology 2, 76-83.

Carmona, R., Gonzalez-Iriarte, M., Macias, D., PerezPomares, J. M., Garcia-Garrido, L., and Munoz-Chapuli, R. (2000). Immunolocalization of the transcription factor Slug in the developing avian heart. Anatomy and embryology 201, 103-109.

Carr, A. M. (2000). Cell cycle. Piecing together the p53 puzzle. Science (New York, NY 287, 1765-1766.

Catalano, A., Rodilossi, S., Rippo, M. R., Caprari, P., and Procopio, A. (2004). Induction of stem cell factor/c-Kit/slug signal transduction in multidrug-resistant malignant mesothelioma cells. The Journal of biological chemistry 279, 46706-46714.

Chan, T. A., Hermeking, H., Lengauer, C., Kinzler, K. W., and Vogelstein, B. (1999). 14-3-3Sigma is required to prevent mitotic catastrophe after DNA damage. Nature 401 , 616-620.

Chandar, N., Billig, B., McMaster, J., and Novak, J. (1992). Inactivation of $\mathrm{p} 53$ gene in human and murine osteosarcoma cells. British journal of cancer 65, 208-214.

Chen, J., Marechal, V., and Levine, A. J. (1993). Mapping of the p53 and mdm-2 interaction domains. Molecular and cellular biology 13, 4107-4114.

Cheng, C. W., Wu, P. E., Yu, J. C., Huang, C. S., Yue, C. T., Wu, C. W., and Shen, C. Y. (2001). Mechanisms of inactivation of E-cadherin in breast carcinoma: modification of the two-hit hypothesis of tumor suppressor gene. Oncogene 20,3814-3823.

Chinnaiyan, A. M., O'Rourke, K., Tewari, M., and Dixit, V. M. (1995). FADD, a novel death domain-containing protein, interacts with the death domain of Fas and initiates apoptosis. Cell 81, 505-512. 
Christofori, G. (2006). New signals from the invasive front. Nature 441, 444-450.

Christophorou, M. A., Martin-Zanca, D., Soucek, L., Lawlor, E. R., Brown-Swigart, L., Verschuren, E. W., and Evan, G. I. (2005). Temporal dissection of p53 function in vitro and in vivo. Nature genetics $37,718-726$.

Cobaleda, C., Perez-Caro, M., Vicente-Duenas, C., and Sanchez-Garcia, I. (2007). Function of Zinc-Finger Transcription Factor SNA12 in Cancer and Development. Annu Rev Genet.

Cobaleda, C., Perez-Losada, J., and Sanchez-Garcia, I. (1998). Chromosomal abnormalities and tumor development: from genes to therapeutic mechanisms. Bioessays 20, 922-930.

Corbo, J. C., Erives, A., Di Gregorio, A., Chang, A., and Levine, M. (1997). Dorsoventral patterning of the vertebrate neural tube is conserved in a protochordate. Development (Cambridge, England) 124, 2335-2344.

Cory, S., and Adams, J. M. (2002). The Bcl2 family: regulators of the cellular life-or-death switch. Nat Rev Cancer 2, 647-656.

Cummins, J. M., and Vogelstein, B. (2004). HAUSP is required for p53 destabilization. Cell cycle (Georgetown, Tex 3, 689-692.

Darnell, J., Lodish, H., and Baltimore, D. (1990). Molecular Cell Biology (cap 24). Scientific American Books, 156-169.

De Craene, B., van Roy, F., and Berx, G. (2005). Unraveling signalling cascades for the Snail family of transcription factors. Cellular signalling 17, 535-547.

Debbas, M., and White, E. (1993). Wild-type p53 mediates apoptosis by E1A, which is inhibited by E1B. Genes \& development 7, 546-554.

del Barrio, M. G., and Nieto, M. A. (2002). Overexpression of Snail family members highlights their ability to promote chick neural crest formation. Development (Cambridge, England) 129, 1583-1593.

Dolbeare, F., Gratzner, H., Pallavicini, M. G., and Gray, J. W. (1983). Flow cytometric measurement of total DNA content and incorporated bromodeoxyuridine. Proceedings of the National Academy of Sciences of the United States of America 80, 5573-5577.

Dominguez, D., Montserrat-Sentis, B., Virgos-Soler, A., Guaita, S., Grueso, J., Porta, M., Puig, I., Baulida, J., Franci, C., and Garcia de Herreros, A. (2003). Phosphorylation regulates the subcellular location and activity of the snail transcriptional repressor. Molecular and cellular biology 23, 5078-5089.

Donehower, L. A. (1996). The p53-deficient mouse: a model for basic and applied cancer studies. Seminars in cancer biology 7, 269-278.

Donehower, L. A., Harvey, M., Slagle, B. L., McArthur, M. J., Montgomery, C. A., Jr., Butel, J. S., and Bradley, A. (1992). Mice deficient for p53 are developmentally normal but susceptible to spontaneous tumours. Nature 356, 215221
Donehower, L. A., Harvey, M., Vogel, H., McArthur, M. J., Montgomery, C. A., Jr., Park, S. H., Thompson, T., Ford, R. J., and Bradley, A. (1995). Effects of genetic background on tumorigenesis in p53-deficient mice. Molecular carcinogenesis $14,16-22$.

Dornan, D., Bheddah, S., Newton, K., Ince, W., Frantz, G. D., Dowd, P., Koeppen, H., Dixit, V. M., and French, D. M. (2004). COP1, the negative regulator of $\mathrm{p} 53$, is overexpressed in breast and ovarian adenocarcinomas. Cancer research 64, 7226-7230.

Efeyan, A., and Serrano, M. (2007). p53: guardian of the genome and policeman of the oncogenes. Cell cycle (Georgetown, Tex 6, 1006-1010.

el-Deiry, W. S. (1998). Regulation of p53 downstream genes. Seminars in cancer biology 8, 345-357.

el-Deiry, W. S., Kern, S. E., Pietenpol, J. A., Kinzler, K. W., and Vogelstein, B. (1992). Definition of a consensus binding site for p53. Nature genetics $1,45-49$.

el-Deiry, W. S., Tokino, T., Velculescu, V. E., Levy, D. B., Parsons, R., Trent, J. M., Lin, D., Mercer, W. E., Kinzler, K. W., and Vogelstein, B. (1993). WAF1, a potential mediator of p53 tumor suppression. Cell 75, 817-825.

Elloul, S., Elstrand, M. B., Nesland, J. M., Trope, C. G., Kvalheim, G., Goldberg, I., Reich, R., and Davidson, B. (2005). Snail, Slug, and Smad-interacting protein 1 as novel parameters of disease aggressiveness in metastatic ovarian and breast carcinoma. Cancer 103, 1631-1643.

Escriva, M., Peiro, S., Herranz, N., Villagrasa, P., Dave, N., Montserrat-Sentis, B., Murray, S. A., Franci, C., Gridley, T., Virtanen, I., and Garcia de Herreros, A. (2008). Repression of PTEN phosphatase by Snaill transcriptional factor during gamma radiation-induced apoptosis. Molecular and cellular biology $28,1528-1540$.

Feinberg, A. P., and Tycko, B. (2004). The history of cancer epigenetics. Nat Rev Cancer 4, 143-153.

Florenes, V. A., Maelandsmo, G. M., Forus, A., Andreassen, A., Myklebost, O., and Fodstad, O. (1994). MDM2 gene amplification and transcript levels in human sarcomas: relationship to TP53 gene status. Journal of the National Cancer Institute 86, 1297-1302.

Fridman, J. S., and Lowe, S. W. (2003). Control of apoptosis by p53. Oncogene 22, 9030-9040.

Fujiwara, S., Corbo, J. C., and Levine, M. (1998). The snail repressor establishes a muscle/notochord boundary in the Ciona embryo. Development (Cambridge, England) 125, 2511-2520.

Fuse, N., Hirose, S., and Hayashi, S. (1994). Diploidy of Drosophila imaginal cells is maintained by a transcriptional repressor encoded by escargot. Genes \& development 8 , $2270-2281$

Gans, C., and Northcutt, R. G. (1983). Neural Crest and the Origin of Vertebrates: A New Head. Science (New York, NY 220, 268-273.

Garcia-Cao, I., Garcia-Cao, M., Martin-Caballero, J., Criado, L. M., Klatt, P., Flores, J. M., Weill, J. C., Blasco, M. A., and Serrano, M. (2002). "Super p53" mice exhibit 
enhanced DNA damage response, are tumor resistant and age normally. The EMBO journal 21, 6225-6235.

Gomez-Lazaro, M., Fernandez-Gomez, F. J., and Jordan, J. (2004). p53: twenty five years understanding the mechanism of genome protection. Journal of physiology and biochemistry $60,287-307$.

Gondo, Y., Nakamura, K., Nakao, K., Sasaoka, T., Ito, K., Kimura, M., and Katsuki, M. (1994). Gene replacement of the p53 gene with the lacZ gene in mouse embryonic stem cells and mice by using two steps of homologous recombination. Biochemical and biophysical research communications 202, 830-837.

Gottifredi, V., and Prives, C. (2001). Molecular biology. Getting p53 out of the nucleus. Science (New York, NY 292, 1851-1852.

Gottlieb, T. M., and Oren, M. (1996). p53 in growth control and neoplasia. Biochimica et biophysica acta $1287,77-102$.

Gottlieb, T. M., and Oren, M. (1998). p53 and apoptosis. Seminars in cancer biology $8,359-368$.

Grau, Y., Carteret, C., and Simpson, P. (1984). Mutations and Chromosomal Rearrangements Affecting the Expression of Snail, a Gene Involved in Embryonic Patterning in DROSOPHILA MELANOGASTER. Genetics 108, 347360.

Greenblatt, M. S., Bennett, W. P., Hollstein, M., and Harris, C. C. (1994). Mutations in the p53 tumor suppressor gene: clues to cancer etiology and molecular pathogenesis. Cancer research $54,4855-4878$.

Grosshans, J., and Wieschaus, E. (2000). A genetic link between morphogenesis and cell division during formation of the ventral furrow in Drosophila. Cell 101, 523-531.

Guaita, S., Puig, I., Franci, C., Garrido, M., Dominguez, D., Batlle, E., Sancho, E., Dedhar, S., De Herreros, A. G., and Baulida, J. (2002). Snail induction of epithelial to mesenchymal transition in tumor cells is accompanied by MUC1 repression and ZEB1 expression. The Journal of biological chemistry 277, 39209-39216.

Gupta, G. P., and Massague, J. (2006). Cancer metastasis: building a framework. Cell 127, 679-695.

Gupta, P. B., Kuperwasser, C., Brunet, J. P., Ramaswamy, S., Kuo, W. L., Gray, J. W., Naber, S. P., and Weinberg, R. A. (2005). The melanocyte differentiation program predisposes to metastasis after neoplastic transformation. Nature genetics 37, 1047-1054.

Hajra, K. M., Chen, D. Y., and Fearon, E. R. (2002). The SLUG zinc-finger protein represses E-cadherin in breast cancer. Cancer research 62, 1613-1618.

Han, J., Flemington, C., Houghton, A. B., Gu, Z., Zambetti, G. P., Lutz, R. J., Zhu, L., and Chittenden, T. (2001). Expression of bbc3, a pro-apoptotic $\mathrm{BH} 3$-only gene, is regulated by diverse cell death and survival signals. Proceedings of the National Academy of Sciences of the United States of America 98, 11318-11323.

Hanahan, D., and Weinberg, R. A. (2000). The hallmarks of cancer. Cell 100, 57-70.
Harper, J. W., Adami, G. R., Wei, N., Keyomarsi, K., and Elledge, S. J. (1993). The p21 Cdk-interacting protein Cip1 is a potent inhibitor of G1 cyclin-dependent kinases. Cell 75, 805-816.

Harris, S. L., and Levine, A. J. (2005). The p53 pathway: positive and negative feedback loops. Oncogene 24, 28992908.

Harvey, M., McArthur, M. J., Montgomery, C. A., Jr., Butel, J. S., Bradley, A., and Donehower, L. A. (1993). Spontaneous and carcinogen-induced tumorigenesis in p53deficient mice. Nature genetics 5, 225-229.

Haupt, Y., Maya, R., Kazaz, A., and Oren, M. (1997). $\mathrm{Mdm} 2$ promotes the rapid degradation of p53. Nature 387 , 296-299.

Hay, E. D. (1995). An overview of epithelio-mesenchymal transformation. Acta anatomica 154, 8-20.

Helton, E. S., and Chen, X. (2007). p53 modulation of the DNA damage response. Journal of cellular biochemistry $100,883-896$.

Hemann, M. T., Zilfou, J. T., Zhao, Z., Burgess, D. J., Hannon, G. J., and Lowe, S. W. (2004). Suppression of tumorigenesis by the p53 target PUMA. Proceedings of the National Academy of Sciences of the United States of America 101, 9333-9338.

Hemavathy, K., Ashraf, S. I., and Ip, Y. T. (2000a). Snail/slug family of repressors: slowly going into the fast lane of development and cancer. Gene 257, 1-12.

Hemavathy, K., Guru, S. C., Harris, J., Chen, J. D., and Ip, Y. T. (2000b). Human Slug is a repressor that localizes to sites of active transcription. Molecular and cellular biology 20, 5087-5095

Hoh, J., Jin, S., Parrado, T., Edington, J., Levine, A. J., and Ott, J. (2002). The p53MH algorithm and its application in detecting p53-responsive genes. Proceedings of the National Academy of Sciences of the United States of America 99, $8467-8472$

Hollstein, M., Rice, K., Greenblatt, M. S., Soussi, T., Fuchs, R., Sorlie, T., Hovig, E., Smith-Sorensen, B., Montesano, R., and Harris, C. C. (1994). Database of p53 gene somatic mutations in human tumors and cell lines. Nucleic acids research 22, 3551-3555.

Horn, H. F., and Vousden, K. H. (2007). Coping with stress: multiple ways to activate p53. Oncogene 26, 1306-1316.

Huang, L. C., Clarkin, K. C., and Wahl, G. M. (1996). Sensitivity and selectivity of the DNA damage sensor responsible for activating p53-dependent G1 arrest. Proceedings of the National Academy of Sciences of the United States of America 93, 4827-4832.

Huber, M. A., Kraut, N., and Beug, H. (2005). Molecular requirements for epithelial-mesenchymal transition during tumor progression. Current opinion in cell biology 17, 548558.

Hupp, T. R., Meek, D. W., Midgley, C. A., and Lane, D. P. (1992). Regulation of the specific DNA binding function of p53. Cell 71, 875-886. 
Ikenouchi, J., Matsuda, M., Furuse, M., and Tsukita, S. (2003). Regulation of tight junctions during the epitheliummesenchyme transition: direct repression of the gene expression of claudins/occludin by Snail. Journal of cell science 116, 1959-1967.

Inoue, A., Seidel, M. G., Wu, W., Kamizono, S., Ferrando, A. A., Bronson, R. T., Iwasaki, H., Akashi, K., Morimoto, A., Hitzler, J. K., et al. (2002). Slug, a highly conserved zinc finger transcriptional repressor, protects hematopoietic progenitor cells from radiation-induced apoptosis in vivo. Cancer cell 2, 279-288.

Inukai, T., Inoue, A., Kurosawa, H., Goi, K., Shinjyo, T., Ozawa, K., Mao, M., Inaba, T., and Look, A. T. (1999). SLUG, a ces-1-related zinc finger transcription factor gene with antiapoptotic activity, is a downstream target of the E2A-HLF oncoprotein. Molecular cell 4, 343-352.

Jacks, T., Remington, L., Williams, B. O., Schmitt, E. M., Halachmi, S., Bronson, R. T., and Weinberg, R. A. (1994). Tumor spectrum analysis in p53-mutant mice. Curr Biol 4, $1-7$.

Jaffe, E. S., Harris, N. L., Stein, H., Vardiman, J. W., and ed. (2001). WHO Classification of Tumours. Pathology and Genetics of Tumours of Hematopoietic and Lymphoid Tissues. 3, 142-154.

Jeanes, A., Gottardi, C. J., and Yap, A. S. (2008). Cadherins and cancer: how does cadherin dysfunction promote tumor progression? Oncogene 27, 6920-6929.

Jeffers, J. R., Parganas, E., Lee, Y., Yang, C., Wang, J., Brennan, J., MacLean, K. H., Han, J., Chittenden, T., Ihle, J. N., et al. (2003). Puma is an essential mediator of p53dependent and -independent apoptotic pathways. Cancer cell $4,321-328$

Jiang, R., Lan, Y., Norton, C. R., Sundberg, J. P., and Gridley, T. (1998). The Slug gene is not essential for mesoderm or neural crest development in mice. Dev Biol $198,277-285$.

Jin, S., and Levine, A. J. (2001). The p53 functional circuit. Journal of cell science $114,4139-4140$.

Julius, M. A., Yan, Q., Zheng, Z., and Kitajewski, J. (2000). $Q$ vectors, bicistronic retroviral vectors for gene transfer. BioTechniques 28, 702-708.

Kajita, M., McClinic, K. N., and Wade, P. A. (2004). Aberrant expression of the transcription factors snail and slug alters the response to genotoxic stress. Molecular and cellular biology $24,7559-7566$.

Kaplan, E. L., and Meier, P. (1958). Nonparemetric estimation from Incomplete Observation. Journal of the Americas Statistical Association 53, 457-481.

Kastan, M. B., Onyekwere, O., Sidransky, D., Vogelstein, B., and Craig, R. W. (1991). Participation of p53 protein in the cellular response to DNA damage. Cancer research 51 , 6304-6311

Kataoka, H., Murayama, T., Yokode, M., Mori, S., Sano, H., Ozaki, H., Yokota, Y., Nishikawa, S., and Kita, T. (2000). A novel snail-related transcription factor Smuc regulates basic helix-loop-helix transcription factor activities via specific Ebox motifs. Nucleic acids research $28,626-633$.
Katoh, M., and Katoh, M. (2003). Identification and characterization of human SNAIL3 (SNAI3) gene in silico. International journal of molecular medicine 11, 383-388.

Kelekar, A., and Thompson, C. B. (1998). Bcl-2-family proteins: the role of the $\mathrm{BH} 3$ domain in apoptosis. Trends in cell biology $8,324-330$

Kemp, C. J., Wheldon, T., and Balmain, A. (1994). p53deficient mice are extremely susceptible to radiationinduced tumorigenesis. Nature genetics 8, 66-69.

Khan, J., Bittner, M. L., Saal, L. H., Teichmann, U., Azorsa, D. O., Gooden, G. C., Pavan, W. J., Trent, J. M., and Meltzer, P. S. (1999). cDNA microarrays detect activation of a myogenic transcription program by the PAX3-FKHR fusion oncogene. Proceedings of the National Academy of Sciences of the United States of America 96, 13264-13269.

Kischkel, F. C., Hellbardt, S., Behrmann, I., Germer, M., Pawlita, M., Krammer, P. H., and Peter, M. E. (1995). Cytotoxicity-dependent APO-1 (Fas/CD95)-associated proteins form a death-inducing signaling complex (DISC) with the receptor. The EMBO journal 14, 5579-5588.

Knust, E., and Bossinger, O. (2002). Composition and formation of intercellular junctions in epithelial cells. Science (New York, NY 298, 1955-1959.

Kubbutat, M. H., Jones, S. N., and Vousden, K. H. (1997). Regulation of p53 stability by Mdm2. Nature 387, 299-303.

Kuo, M. H., and Allis, C. D. (1999). In vivo cross-linking and immunoprecipitation for studying dynamic Protein:DNA associations in a chromatin environment. Methods (San Diego, Calif 19, 425-433.

LaBonne, C., and Bronner-Fraser, M. (2000). Snail-related transcriptional repressors are required in Xenopus for both the induction of the neural crest and its subsequent migration. Developmental biology 221, 195-205.

Lambert, P. F., Kashanchi, F., Radonovich, M. F., Shiekhattar, R., and Brady, J. N. (1998). Phosphorylation of p53 serine 15 increases interaction with CBP. The Journal of biological chemistry $273,33048-33053$.

Lane, D. P. (1992). Cancer. p53, guardian of the genome. Nature 358, 15-16.

Langeland, J. A., Tomsa, J. M., Jackman, W. R., Jr., and Kimmel, C. B. (1998). An amphioxus snail gene: expression in paraxial mesoderm and neural plate suggests a conserved role in patterning the chordate embryo. Development genes and evolution 208, 569-577.

Lavia, P., Mileo, A. M., Giordano, A., and Paggi, M. G. (2003). Emerging roles of DNA tumor viruses in cell proliferation: new insights into genomic instability. Oncogene 22, 6508-6516.

Lee, S. H., Lee, S. J., Jung, Y. S., Xu, Y., Kang, H. S., Ha, N. C., and Park, B. J. (2009). Blocking of p53-Snail binding, promoted by oncogenic K-Ras, recovers p53 expression and function. Neoplasia (New York, NY 11, 22-31, 26p following 31

Leng, R. P., Lin, Y., Ma, W., Wu, H., Lemmers, B., Chung, S., Parant, J. M., Lozano, G., Hakem, R., and Benchimol, S. (2003). Pirh2, a p53-induced ubiquitin-protein ligase, promotes p53 degradation. Cell 112, 779-791. 
Levine, A. J. (1997). p53, the cellular gatekeeper for growth and division. Cell 88, 323-331.

Levine, A. J., Momand, J., and Finlay, C. A. (1991). The p53 tumour suppressor gene. Nature 351, 453-456.

Li, J., and Yuan, J. (2008). Caspases in apoptosis and beyond. Oncogene 27, 6194-6206.

Li, M., Brooks, C. L., Kon, N., and Gu, W. (2004). A dynamic role of HAUSP in the p53-Mdm2 pathway. Molecular cell 13, 879-886.

Lin, J., Chen, J., Elenbaas, B., and Levine, A. J. (1994). Several hydrophobic amino acids in the p53 amino-terminal domain are required for transcriptional activation, binding to mdm- 2 and the adenovirus 5 E1B $55-\mathrm{kD}$ protein. Genes \& development $8,1235-1246$.

Liu, L. F. (1989). DNA topoisomerase poisons as antitumor drugs. Annual review of biochemistry 58, 351-375.

Lopez-Girona, A., Furnari, B., Mondesert, O., and Russell, P. (1999). Nuclear localization of Cdc25 is regulated by DNA damage and a 14-3-3 protein. Nature 397, 172-175.

Lowe, S. W., Cepero, E., and Evan, G. (2004). Intrinsic tumour suppression. Nature 432, 307-315.

Lowe, S. W., and Ruley, H. E. (1993). Stabilization of the p53 tumor suppressor is induced by adenovirus 5 E1A and accompanies apoptosis. Genes \& development 7, 535-545.

Lowe, S. W., Ruley, H. E., Jacks, T., and Housman, D. E. (1993a). p53-dependent apoptosis modulates the cytotoxicity of anticancer agents. Cell 74, 957-967.

Lowe, S. W., Schmitt, E. M., Smith, S. W., Osborne, B. A., and Jacks, T. (1993b). p53 is required for radiation-induced apoptosis in mouse thymocytes. Nature $362,847-849$.

Lozano, G., and Liu, G. (1998). Mouse models dissect the role of p53 in cancer and development. Seminars in cancer biology $8,337-344$

Lu, H., and Levine, A. J. (1995). Human TAFII31 protein is a transcriptional coactivator of the p53 protein. Proceedings of the National Academy of Sciences of the United States of America 92, 5154-5158.

Mackay, J. P., and Crossley, M. (1998). Zinc fingers are sticking together. Trends in biochemical sciences 23, 1-4.

Malkin, D., Li, F. P., Strong, L. C., Fraumeni, J. F., Jr., Nelson, C. E., Kim, D. H., Kassel, J., Gryka, M. A., Bischoff, F. Z., Tainsky, M. A., and et al. (1990). Germ line p53 mutations in a familial syndrome of breast cancer, sarcomas, and other neoplasms. Science (New York, NY $250,1233-1238$

Malumbres, M., and Barbacid, M. (2009). Cell cycle, CDKs and cancer: a changing paradigm. Nat Rev Cancer 9, 153166.

Manzanares, M., Blanco, M. J., and Nieto, M. A. (2004). Snail3 orthologues in vertebrates: divergent members of the Snail zinc-finger gene family. Development genes and evolution $214,47-53$
Manzanares, M., Locascio, A., and Nieto, M. A. (2001). The increasing complexity of the Snail gene superfamily in metazoan evolution. Trends Genet 17, 178-181.

Marchenko, N. D., Zaika, A., and Moll, U. M. (2000). Death signal-induced localization of p53 protein to mitochondria. A potential role in apoptotic signaling. The Journal of biological chemistry 275, 16202-16212.

Martin, S. J., Reutelingsperger, C. P., McGahon, A. J., Rader, J. A., van Schie, R. C., LaFace, D. M., and Green, D. R. (1995). Early redistribution of plasma membrane phosphatidylserine is a general feature of apoptosis regardless of the initiating stimulus: inhibition by overexpression of Bcl-2 and Abl. The Journal of experimental medicine $182,1545-1556$.

Martinez-Alvarez, C., Blanco, M. J., Perez, R., Rabadan, M. A., Aparicio, M., Resel, E., Martinez, T., and Nieto, M. A. (2004). Snail family members and cell survival in physiological and pathological cleft palates. Developmental biology 265, 207-218.

Martins, C. P., Brown-Swigart, L., and Evan, G. I. (2006). Modeling the therapeutic efficacy of p53 restoration in tumors. Cell 127, 1323-1334.

May, P., and May, E. (1999). Twenty years of p53 research: structural and functional aspects of the p53 protein. Oncogene 18, 7621-7636.

Mayor, R., Guerrero, N., Young, R. M., Gomez-Skarmeta, J. L., and Cuellar, C. (2000). A novel function for the Xslug gene: control of dorsal mesendoderm development by repressing BMP-4. Mechanisms of development 97, 47-56.

McCurrach, M. E., and Lowe, S. W. (2001). Methods for studying pro- and antiapoptotic genes in nonimmortal cells. Methods in cell biology 66, 197-227.

Mehlen, P., and Puisieux, A. (2006). Metastasis: a question of life or death. Nat Rev Cancer 6, 449-458.

Michael, D., and Oren, M. (2003). The p53-Mdm2 module and the ubiquitin system. Seminars in cancer biology 13, 49-

Midgley, C. A., Fisher, C. J., Bartek, J., Vojtesek, B., Lane, D., and Barnes, D. M. (1992). Analysis of p53 expression in human tumours: an antibody raised against human p53 expressed in Escherichia coli. Journal of cell science 101 ( Pt 1), 183-189.

Mihara, M., Erster, S., Zaika, A., Petrenko, O., Chittenden, T., Pancoska, P., and Moll, U. M. (2003). p53 has a direct apoptogenic role at the mitochondria. Molecular cell 11, 577-590.

Miyashita, T., and Reed, J. C. (1995). Tumor suppressor p53 is a direct transcriptional activator of the human bax gene. Cell 80, 293-299.

Miyoshi, A., Kitajima, Y., Kido, S., Shimonishi, T., Matsuyama, S., Kitahara, K., and Miyazaki, K. (2005). Snail accelerates cancer invasion by upregulating MMP expression and is associated with poor prognosis of hepatocellular carcinoma. British journal of cancer 92, 252258 .

Moreno-Bueno, G., Cubillo, E., Sarrio, D., Peinado, H., Rodriguez-Pinilla, S. M., Villa, S., Bolos, V., Jorda, M., 
Fabra, A., Portillo, F., et al. (2006). Genetic profiling of epithelial cells expressing E-cadherin repressors reveals a distinct role for Snail, Slug, and E47 factors in epithelialmesenchymal transition. Cancer research 66, 9543-9556.

Morgenstern, J. P., and Land, H. (1990). Advanced mammalian gene transfer: high titre retroviral vectors with multiple drug selection markers and a complementary helper-free packaging cell line. Nucleic acids research 18 , 3587-3596.

Murray, S. A., Oram, K. F., and Gridley, T. (2007). Multiple functions of Snail family genes during palate development in mice. Development (Cambridge, England) 134, 17891797.

Nakano, K., and Vousden, K. H. (2001). PUMA, a novel proapoptotic gene, is induced by p53. Molecular cell 7, 683694.

Nakayama, H., Scott, I. C., and Cross, J. C. (1998). The transition to endoreduplication in trophoblast giant cells is regulated by the mSNA zinc finger transcription factor. Developmental biology 199, 150-163.

Navarro, P., Lozano, E., and Cano, A. (1993). Expression of E- or P-cadherin is not sufficient to modify the morphology and the tumorigenic behavior of murine spindle carcinoma cells. Possible involvement of plakoglobin. Journal of cell science 105 ( Pt 4), 923-934.

Nibu, Y., Zhang, H., Bajor, E., Barolo, S., Small, S., and Levine, M. (1998). dCtBP mediates transcriptional repression by Knirps, Kruppel and Snail in the Drosophila embryo. The EMBO journal 17, 7009-7020.

Nicholson, D. W., and Thornberry, N. A. (2003). Apoptosis. Life and death decisions. Science (New York, NY 299, 214215.

Nieto, M. A. (2002). The snail superfamily of zinc-finger transcription factors. Nature reviews 3, 155-166.

Nieto, M. A. (2008). Epithelial-Mesenchymal Transitions in development and disease: old views and new perspectives. The International journal of developmental biology.

Oliner, J. D., Pietenpol, J. A., Thiagalingam, S., Gyuris, J., Kinzler, K. W., and Vogelstein, B. (1993). Oncoprotein MDM2 conceals the activation domain of tumour suppressor p53. Nature 362, 857-860.

Olmeda, D., Jorda, M., Peinado, H., Fabra, A., and Cano, A. (2007). Snail silencing effectively suppresses tumour growth and invasiveness. Oncogene 26, 1862-1874.

Olmeda, D., Montes, A., Moreno-Bueno, G., Flores, J. M., Portillo, F., and Cano, A. (2008). Snail and Snai2 collaborate on tumor growth and metastasis properties of mouse skin carcinoma cell lines. Oncogene.

Palacios, R., and Steinmetz, M. (1985). Il-3-dependent mouse clones that express B-220 surface antigen, contain Ig genes in germ-line configuration, and generate B lymphocytes in vivo. Cell 41, 727-734.

Palmer, H. G., Larriba, M. J., Garcia, J. M., OrdonezMoran, P., Pena, C., Peiro, S., Puig, I., Rodriguez, R., de la Fuente, R., Bernad, A., et al. (2004). The transcription factor SNAIL represses vitamin D receptor expression and responsiveness in human colon cancer. Nature medicine 10 , 917-919.

Peinado, H., Marin, F., Cubillo, E., Stark, H. J., Fusenig, N., Nieto, M. A., and Cano, A. (2004a). Snail and E47 repressors of E-cadherin induce distinct invasive and angiogenic properties in vivo. Journal of cell science 117 , $2827-2839$

Peinado, H., Olmeda, D., and Cano, A. (2007). Snail, Zeb and bHLH factors in tumour progression: an alliance against the epithelial phenotype? Nat Rev Cancer 7, 415-428.

Peinado, H., Portillo, F., and Cano, A. (2004b). Transcriptional regulation of cadherins during development and carcinogenesis. The International journal of developmental biology 48, 365-375

Peinado, H., Quintanilla, M., and Cano, A. (2003). Transforming growth factor beta-1 induces snail transcription factor in epithelial cell lines: mechanisms for epithelial mesenchymal transitions. The Journal of biological chemistry $278,21113-21123$.

Peiro, S., Escriva, M., Puig, I., Barbera, M. J., Dave, N., Herranz, N., Larriba, M. J., Takkunen, M., Franci, C., Munoz, A., et al. (2006). Snaill transcriptional repressor binds to its own promoter and controls its expression. Nucleic acids research 34, 2077-2084

Perez-Losada, J., Sanchez-Martin, M., Perez-Caro, M., Perez-Mancera, P. A., and Sanchez-Garcia, I. (2003). The radioresistance biological function of the $\mathrm{SCF} / \mathrm{kit}$ signaling pathway is mediated by the zinc-finger transcription factor Slug. Oncogene 22, 4205-4211.

Perez-Losada, J., Sanchez-Martin, M., Rodriguez-Garcia, A., Sanchez, M. L., Orfao, A., Flores, T., and SanchezGarcia, I. (2002). Zinc-finger transcription factor Slug contributes to the function of the stem cell factor c-kit signaling pathway. Blood 100, 1274-1286.

Perez-Mancera, P. A., Gonzalez-Herrero, I., Maclean, K., Turner, A. M., Yip, M. Y., Sanchez-Martin, M., Garcia, J. L., Robledo, C., Flores, T., Gutierrez-Adan, A., et al. (2006). SLUG (SNAI2) overexpression in embryonic development. Cytogenetic and genome research 114, 24-29.

Perez-Mancera, P. A., Gonzalez-Herrero, I., Perez-Caro, M., Gutierrez-Cianca, N., Flores, T., Gutierrez-Adan, A., Pintado, B., Sanchez-Martin, M., and Sanchez-Garcia, I. (2005a). SLUG in cancer development. Oncogene 24, 30733082 .

Perez-Mancera, P. A., Perez-Caro, M., Gonzalez-Herrero, I., Flores, T., Orfao, A., de Herreros, A. G., Gutierrez-Adan, A., Pintado, B., Sagrera, A., Sanchez-Martin, M., and Sanchez-Garcia, I. (2005b). Cancer development induced by graded expression of Snail in mice. Human molecular genetics $14,3449-3461$.

Perez-Moreno, M., Jamora, C., and Fuchs, E. (2003). Sticky business: orchestrating cellular signals at adherens junctions. Cell 112, 535-548.

Perez-Moreno, M. A., Locascio, A., Rodrigo, I., Dhondt, G., Portillo, F., Nieto, M. A., and Cano, A. (2001). A new role for E12/E47 in the repression of E-cadherin expression and epithelial-mesenchymal transitions. The Journal of biological chemistry $276,27424-27431$. 
Perry, M. E., Piette, J., Zawadzki, J. A., Harvey, D., and Levine, A. J. (1993). The mdm-2 gene is induced in response to UV light in a p53-dependent manner. Proceedings of the National Academy of Sciences of the United States of America 90, 11623-11627.

Peter, M. E., and Krammer, P. H. (2003). The CD95(APO$1 /$ Fas) DISC and beyond. Cell death and differentiation 10, 26-35.

Picksley, S. M., and Lane, D. P. (1993). The p53-mdm2 autoregulatory feedback loop: a paradigm for the regulation of growth control by p53? Bioessays 15, 689-690.

Pietenpol, J. A., Tokino, T., Thiagalingam, S., el-Deiry, W. S., Kinzler, K. W., and Vogelstein, B. (1994). Sequencespecific transcriptional activation is essential for growth suppression by p53. Proceedings of the National Academy of Sciences of the United States of America 91, 1998-2002.

Prives, C., and Hall, P. A. (1999). The p53 pathway. The Journal of pathology 187, 112-126.

Purdie, C. A., Harrison, D. J., Peter, A., Dobbie, L., White, S., Howie, S. E., Salter, D. M., Bird, C. C., Wyllie, A. H., Hooper, M. L., and et al. (1994). Tumour incidence, spectrum and ploidy in mice with a large deletion in the p53 gene. Oncogene 9, 603-609.

Roark, M., Sturtevant, M. A., Emery, J., Vaessin, H., Grell, E., and Bier, E. (1995). scratch, a pan-neural gene encoding a zinc finger protein related to snail, promotes neuronal development. Genes \& development 9, 2384-2398.

Romano, L. A., and Runyan, R. B. (2000). Slug is an essential target of TGFbeta2 signaling in the developing chicken heart. Developmental biology 223, 91-102.

Romer, L., Klein, C., Dehner, A., Kessler, H., and Buchner, J. (2006). p53--a natural cancer killer: structural insights and therapeutic concepts. Angewandte Chemie (International ed $45,6440-6460$

Rosivatz, E., Becker, I., Specht, K., Fricke, E., Luber, B., Busch, R., Hofler, H., and Becker, K. F. (2002). Differential expression of the epithelial-mesenchymal transition regulators snail, SIP1, and twist in gastric cancer. The American journal of pathology 161, 1881-1891.

Saito, T., Oda, Y., Kawaguchi, K., Sugimachi, K., Yamamoto, H., Tateishi, N., Tanaka, K., Matsuda, S., Iwamoto, Y., Ladanyi, M., and Tsuneyoshi, M. (2004). Ecadherin mutation and Snail overexpression as alternative mechanisms of E-cadherin inactivation in synovial sarcoma. Oncogene 23, 8629-8638.

Sakai, D., Suzuki, T., Osumi, N., and Wakamatsu, Y. (2006). Cooperative action of Sox9, Snail2 and PKA signaling in early neural crest development. Development (Cambridge, England) 133, 1323-1333.

Sakamuro, D., Sabbatini, P., White, E., and Prendergast, G. C. (1997). The polyproline region of p53 is required to activate apoptosis but not growth arrest. Oncogene 15, 887898.

Sanchez-Garcia, I. (1997). Consequences of chromosomal abnormalities in tumor development. Annu Rev Genet 31, 429-453.
Savagner, P., Yamada, K. M., and Thiery, J. P. (1997). The zinc-finger protein slug causes desmosome dissociation, an initial and necessary step for growth factor-induced epithelial-mesenchymal transition. The Journal of cell biology 137, 1403-1419.

Schmitt, C. A., Fridman, J. S., Yang, M., Baranov, E., Hoffman, R. M., and Lowe, S. W. (2002). Dissecting p53 tumor suppressor functions in vivo. Cancer cell 1, 289-298.

Schultze, N., Burki, Y., Lang, Y., Certa, U., and Bluethmann, H. (1996). Efficient control of gene expression by single step integration of the tetracycline system in transgenic mice. Nature biotechnology 14, 499-503.

Sefton, M., Sanchez, S., and Nieto, M. A. (1998). Conserved and divergent roles for members of the Snail family of transcription factors in the chick and mouse embryo. Development (Cambridge, England) 125, 3111-3121.

Serrano, M., Lin, A. W., McCurrach, M. E., Beach, D., and Lowe, S. W. (1997). Oncogenic ras provokes premature cell senescence associated with accumulation of p53 and p16INK4a. Cell 88, 593-602.

Sharpless, N. E., and DePinho, R. A. (1999). The INK4A/ARF locus and its two gene products. Current opinion in genetics \& development 9, 22-30.

Shaulsky, G., Goldfinger, N., Ben-Ze'ev, A., and Rotter, V. (1990). Nuclear accumulation of p53 protein is mediated by several nuclear localization signals and plays a role in tumorigenesis. Molecular and cellular biology 10, 65656577.

Sherr, C. J. (1994). G1 phase progression: cycling on cue. Cell 79, 551-555.

Shibue, T., Takeda, K., Oda, E., Tanaka, H., Murasawa, H., Takaoka, A., Morishita, Y., Akira, S., Taniguchi, T., and Tanaka, N. (2003). Integral role of Noxa in p53-mediated apoptotic response. Genes \& development 17, 2233-2238

Shieh, S. Y., Ahn, J., Tamai, K., Taya, Y., and Prives, C. (2000). The human homologs of checkpoint kinases Chk1 and Cds1 (Chk2) phosphorylate p53 at multiple DNA damage-inducible sites. Genes \& development 14, 289-300.

Shieh, S. Y., Ikeda, M., Taya, Y., and Prives, C. (1997). DNA damage-induced phosphorylation of p53 alleviates inhibition by MDM2. Cell 91, 325-334.

Smith, M. L., Ford, J. M., Hollander, M. C., Bortnick, R. A., Amundson, S. A., Seo, Y. R., Deng, C. X., Hanawalt, P. C., and Fornace, A. J., Jr. (2000). p53-mediated DNA repair responses to UV radiation: studies of mouse cells lacking p53, p21, and/or gadd45 genes. Molecular and cellular biology 20, 3705-3714.

Sommer, R. J., and Tautz, D. (1994). Expression patterns of twist and snail in Tribolium (Coleoptera) suggest a homologous formation of mesoderm in long and short germ band insects. Developmental genetics 15, 32-37.

Soussi, T., Caron de Fromentel, C., and May, P. (1990). Structural aspects of the p53 protein in relation to gene evolution. Oncogene 5, 945-952.

Soussi, T., and May, P. (1996). Structural aspects of the p53 protein in relation to gene evolution: a second look. Journal of molecular biology 260, 623-637. 
Srivastava, S., Zou, Z. Q., Pirollo, K., Blattner, W., and Chang, E. H. (1990). Germ-line transmission of a mutated p53 gene in a cancer-prone family with Li-Fraumeni syndrome. Nature 348, 747-749.

Stewart, C., and Ratain, M. (1997). Principles and Practice of Oncology. DeVita Jr V, Hellmann S and Rosenberg SA (eds) Lipincott-Raven: Philadelphia, 452-467.

Stewart, C. L., Soria, A. M., and Hamel, P. A. (2001). Integration of the pRB and $\mathrm{p} 53$ cell cycle control pathways. Journal of neuro-oncology 51, 183-204.

Stommel, J. M., Marchenko, N. D., Jimenez, G. S., Moll, U. M., Hope, T. J., and Wahl, G. M. (1999). A leucine-rich nuclear export signal in the p53 tetramerization domain: regulation of subcellular localization and p53 activity by NES masking. The EMBO journal 18, 1660-1672.

Sugimachi, K., Tanaka, S., Kameyama, T., Taguchi, K., Aishima, S., Shimada, M., Sugimachi, K., and Tsuneyoshi, M. (2003). Transcriptional repressor snail and progression of human hepatocellular carcinoma. Clin Cancer Res 9, 2657-2664.

Sui, G., Affar el, B., Shi, Y., Brignone, C., Wall, N. R., Yin, P., Donohoe, M., Luke, M. P., Calvo, D., Grossman, S. R., and Shi, Y. (2004). Yin Yang 1 is a negative regulator of p53. Cell 117, 859-872

Tainsky, M. A., Bischoff, F. Z., and Strong, L. C. (1995). Genomic instability due to germline p53 mutations drives preneoplastic progression toward cancer in human cells. Cancer metastasis reviews 14, 43-48.

Takeichi, M. (1993). Cadherins in cancer: implications for invasion and metastasis. Current opinion in cell biology 5 , 806-811

Thiery, J. P. (2002). Epithelial-mesenchymal transitions in tumour progression. Nat Rev Cancer 2, 442-454.

Thiery, J. P. (2003). Epithelial-mesenchymal transitions in development and pathologies. Current opinion in cell biology $15,740-746$.

Thiery, J. P., and Sleeman, J. P. (2006). Complex networks orchestrate epithelial-mesenchymal transitions. Nature reviews $7,131-142$.

Thomas, A., and White, E. (1998). Suppression of the p300dependent mdm2 negative-feedback loop induces the p53 apoptotic function. Genes \& development 12, 1975-1985.

Timmerman, L. A., Grego-Bessa, J., Raya, A., Bertran, E., Perez-Pomares, J. M., Diez, J., Aranda, S., Palomo, S., McCormick, F., Izpisua-Belmonte, J. C., and de la Pompa, J. L. (2004). Notch promotes epithelial-mesenchymal transition during cardiac development and oncogenic transformation. Genes \& development 18, 99-115.

Toledo, F., and Wahl, G. M. (2006). Regulating the p53 pathway: in vitro hypotheses, in vivo veritas. Nat Rev Cancer 6, 909-923.

Tripathi, M. K., Misra, S., and Chaudhuri, G. (2005a). Negative regulation of the expressions of cytokeratins 8 and 19 by SLUG repressor protein in human breast cells. Biochemical and biophysical research communications 329 , 508-515.
Tripathi, M. K., Misra, S., Khedkar, S. V., Hamilton, N., Irvin-Wilson, C., Sharan, C., Sealy, L., and Chaudhuri, G. (2005b). Regulation of BRCA2 gene expression by the SLUG repressor protein in human breast cells. The Journal of biological chemistry $280,17163-17171$.

Tsukada, T., Tomooka, Y., Takai, S., Ueda, Y., Nishikawa, S., Yagi, T., Tokunaga, T., Takeda, N., Suda, Y., Abe, S., and et al. (1993). Enhanced proliferative potential in culture of cells from p53-deficient mice. Oncogene 8, 3313-3322.

Turner, F. E., Broad, S., Khanim, F. L., Jeanes, A., Talma, S., Hughes, S., Tselepis, C., and Hotchin, N. A. (2006). Slug regulates integrin expression and cell proliferation in human epidermal keratinocytes. The Journal of biological chemistry $281,21321-21331$

Uchikado, Y., Natsugoe, S., Okumura, H., Setoyama, T., Matsumoto, M., Ishigami, S., and Aikou, T. (2005). Slug Expression in the E-cadherin preserved tumors is related to prognosis in patients with esophageal squamous cell carcinoma. Clin Cancer Res 11, 1174-1180.

Valdes, F., Murillo, M. M., Valverde, A. M., Herrera, B., Sanchez, A., Benito, M., Fernandez, M., and Fabregat, I. (2004). Transforming growth factor-beta activates both proapoptotic and survival signals in fetal rat hepatocytes. Experimental cell research 292, 209-218.

Vassilev, L. T., Vu, B. T., Graves, B., Carvajal, D., Podlaski, F., Filipovic, Z., Kong, N., Kammlott, U., Lukacs, C., Klein, C., et al. (2004). In vivo activation of the p53 pathway by small-molecule antagonists of MDM2. Science (New York, NY 303, 844-848.

Vaziri, H., and Benchimol, S. (1996). From telomere loss to p53 induction and activation of a DNA-damage pathway at senescence: the telomere loss/DNA damage model of cell aging. Experimental gerontology 31, 295-301.

Vega, S., Morales, A. V., Ocana, O. H., Valdes, F., Fabregat, I., and Nieto, M. A. (2004). Snail blocks the cell cycle and confers resistance to cell death. Genes \& development 18, 1131-1143.

Veltmaat, J. M., Orelio, C. C., Ward-Van Oostwaard, D., Van Rooijen, M. A., Mummery, C. L., and Defize, L. H. (2000). Snail is an immediate early target gene of parathyroid hormone related peptide signaling in parietal endoderm formation. The International journal of developmental biology 44, 297-307.

Venot, C., Maratrat, M., Dureuil, C., Conseiller, E., Bracco, L., and Debussche, L. (1998). The requirement for the p53 proline-rich functional domain for mediation of apoptosis is correlated with specific PIG3 gene transactivation and with transcriptional repression. The EMBO journal 17, 46684679.

Ventura, A., Kirsch, D. G., McLaughlin, M. E., Tuveson, D. A., Grimm, J., Lintault, L., Newman, J., Reczek, E. E., Weissleder, R., and Jacks, T. (2007). Restoration of p53 function leads to tumour regression in vivo. Nature 445 , 661-665.

Villunger, A., Michalak, E. M., Coultas, L., Mullauer, F., Bock, G., Ausserlechner, M. J., Adams, J. M., and Strasser, A. (2003). p53- and drug-induced apoptotic responses mediated by BH3-only proteins puma and noxa. Science (New York, NY 302, 1036-1038. 
Vogelstein, B., and Kinzler, K. W. (1994). Tumoursuppressor genes. X-rays strike p53 again. Nature 370, 174175 .

Vogelstein, B., Lane, D., and Levine, A. J. (2000). Surfing the p53 network. Nature 408, 307-310.

Vousden, K. H., and Lu, X. (2002). Live or let die: the cell's response to p53. Nat Rev Cancer 2, 594-604.

Vousden, K. H., and Prives, C. (2005). P53 and prognosis: new insights and further complexity. Cell 120, 7-10.

Wada, S., and Saiga, H. (1999). Cloning and embryonic expression of Hrsna, a snail family gene of the ascidian Halocynthia roretzi: implication in the origins of mechanisms for mesoderm specification and body axis formation in chordates. Development, growth \& differentiation 41, 9-18.

Wahl, G. M., Linke, S. P., Paulson, T. G., and Huang, L. C. (1997). Maintaining genetic stability through TP53 mediated checkpoint control. Cancer surveys 29, 183-219.

Walker, K. K., and Levine, A. J. (1996). Identification of a novel p53 functional domain that is necessary for efficient growth suppression. Proceedings of the National Academy of Sciences of the United States of America 93, 1533515340 .

Wang, J., Chun, H. J., Wong, W., Spencer, D. M., and Lenardo, M. J. (2001). Caspase-10 is an initiator caspase in death receptor signaling. Proceedings of the National Academy of Sciences of the United States of America 98, 13884-13888.

Wang, P., Reed, M., Wang, Y., Mayr, G., Stenger, J. E., Anderson, M. E., Schwedes, J. F., and Tegtmeyer, P. (1994). p53 domains: structure, oligomerization, and transformation. Molecular and cellular biology 14, 5182-5191.

Watson, I. R., and Irwin, M. S. (2006). Ubiquitin and ubiquitin-like modifications of the p53 family. Neoplasia (New York, NY 8, 655-666.

White, E. (1998). Regulation of Apoptosis by Adenovirus E1A and E1B Oncogenes. Seminars in Virology, Academic Press 8, 505-513.

Whiteley, M., Noguchi, P. D., Sensabaugh, S. M., Odenwald, W. F., and Kassis, J. A. (1992). The Drosophila gene escargot encodes a zinc finger motif found in snailrelated genes. Mechanisms of development 36, 117-127.

Woods, D. B., and Vousden, K. H. (2001). Regulation of p53 function. Experimental cell research 264, 56-66.

Wu, W. S., Heinrichs, S., Xu, D., Garrison, S. P., Zambetti, G. P., Adams, J. M., and Look, A. T. (2005). Slug antagonizes p53-mediated apoptosis of hematopoietic progenitors by repressing puma. Cell 123, 641-653.

Wu, X., Bayle, J. H., Olson, D., and Levine, A. J. (1993). The p53-mdm-2 autoregulatory feedback loop. Genes \& development 7, 1126-1132.

Xiong, Y., Hannon, G. J., Zhang, H., Casso, D., Kobayashi, R., and Beach, D. (1993). p21 is a universal inhibitor of cyclin kinases. Nature 366, 701-704.
Xue, W., Zender, L., Miething, C., Dickins, R. A., Hernando, E., Krizhanovsky, V., Cordon-Cardo, C., and Lowe, S. W. (2007). Senescence and tumour clearance is triggered by p53 restoration in murine liver carcinomas. Nature 445, 656-660

Yamashita, S., Miyagi, C., Fukada, T., Kagara, N., Che, Y. S., and Hirano, T. (2004). Zinc transporter LIVI controls epithelial-mesenchymal transition in zebrafish gastrula organizer. Nature 429, 298-302.

Yanez-Mo, M., Lara-Pezzi, E., Selgas, R., Ramirez-Huesca, M., Dominguez-Jimenez, C., Jimenez-Heffernan, J. A., Aguilera, A., Sanchez-Tomero, J. A., Bajo, M. A., Alvarez, V., et al. (2003). Peritoneal dialysis and epithelial-tomesenchymal transition of mesothelial cells. The New England journal of medicine 348, 403-413.

Yang, W. H., Kim, J. E., Nam, H. W., Ju, J. W., Kim, H. S., Kim, Y. S., and Cho, J. W. (2006). Modification of p53 with O-linked $\mathrm{N}$-acetylglucosamine regulates p53 activity and stability. Nature cell biology 8, 1074-1083.

Yang, Z., Rayala, S., Nguyen, D., Vadlamudi, R. K., Chen, S., and Kumar, R. (2005). Pak1 phosphorylation of snail, a master regulator of epithelial-to-mesenchyme transition, modulates snail's subcellular localization and functions. Cancer research 65, 3179-3184.

Yokoyama, K., Kamata, N., Fujimoto, R., Tsutsumi, S., Tomonari, M., Taki, M., Hosokawa, H., and Nagayama, M. (2003). Increased invasion and matrix metalloproteinase-2 expression by Snail-induced mesenchymal transition in squamous cell carcinomas. International journal of oncology $22,891-898$

Yook, J. I., Li, X. Y., Ota, I., Fearon, E. R., and Weiss, S. J. (2005). Wnt-dependent regulation of the E-cadherin repressor snail. The Journal of biological chemistry 280 , 11740-11748.

Zauberman, A., Barak, Y., Ragimov, N., Levy, N., and Oren, M. (1993). Sequence-specific DNA binding by p53: identification of target sites and lack of binding to p53 MDM2 complexes. The EMBO journal 12, 2799-2808.

Zhivotovsky, B., and Kroemer, G. (2004). Apoptosis and genomic instability. Nature reviews 5, 752-762.

Zhou, B. B., and Elledge, S. J. (2000). The DNA damage response: putting checkpoints in perspective. Nature 408, 433-439.

Zhou, B. P., Deng, J., Xia, W., Xu, J., Li, Y. M., Gunduz, M., and Hung, M. C. (2004). Dual regulation of Snail by GSK-3beta-mediated phosphorylation in control of epithelial-mesenchymal transition. Nature cell biology 6 , 931-940.

Zhou, J., Ahn, J., Wilson, S. H., and Prives, C. (2001). A role for p53 in base excision repair. The EMBO journal 20, 914-923.

Zhu, J., Jiang, J., Zhou, W., Zhu, K., and Chen, X. (1999). Differential regulation of cellular target genes by p53 devoid of the PXXP motifs with impaired apoptotic activity. Oncogene 18, 2149-2155.

Zurer, I., Hofseth, L. J., Cohen, Y., Xu-Welliver, M., Hussain, S. P., Harris, C. C., and Rotter, V. (2004). The role 
of p53 in base excision repair following genotoxic stress. Carcinogenesis 25, 11-19. 